UNIVERSIDADE DE SÃO PAULO

FACULDADE DE FILOSOFIA ,LETRAS E CIÊNCIAS HUMANAS

DEPARTAMENTO GEOGRAFIA

O Território de Trabalho dos Carregadores Piauienses

no Terminal da CEAGESP:

Modernização, Mobilização e a Migração

SUELI DE CASTRO GOMES

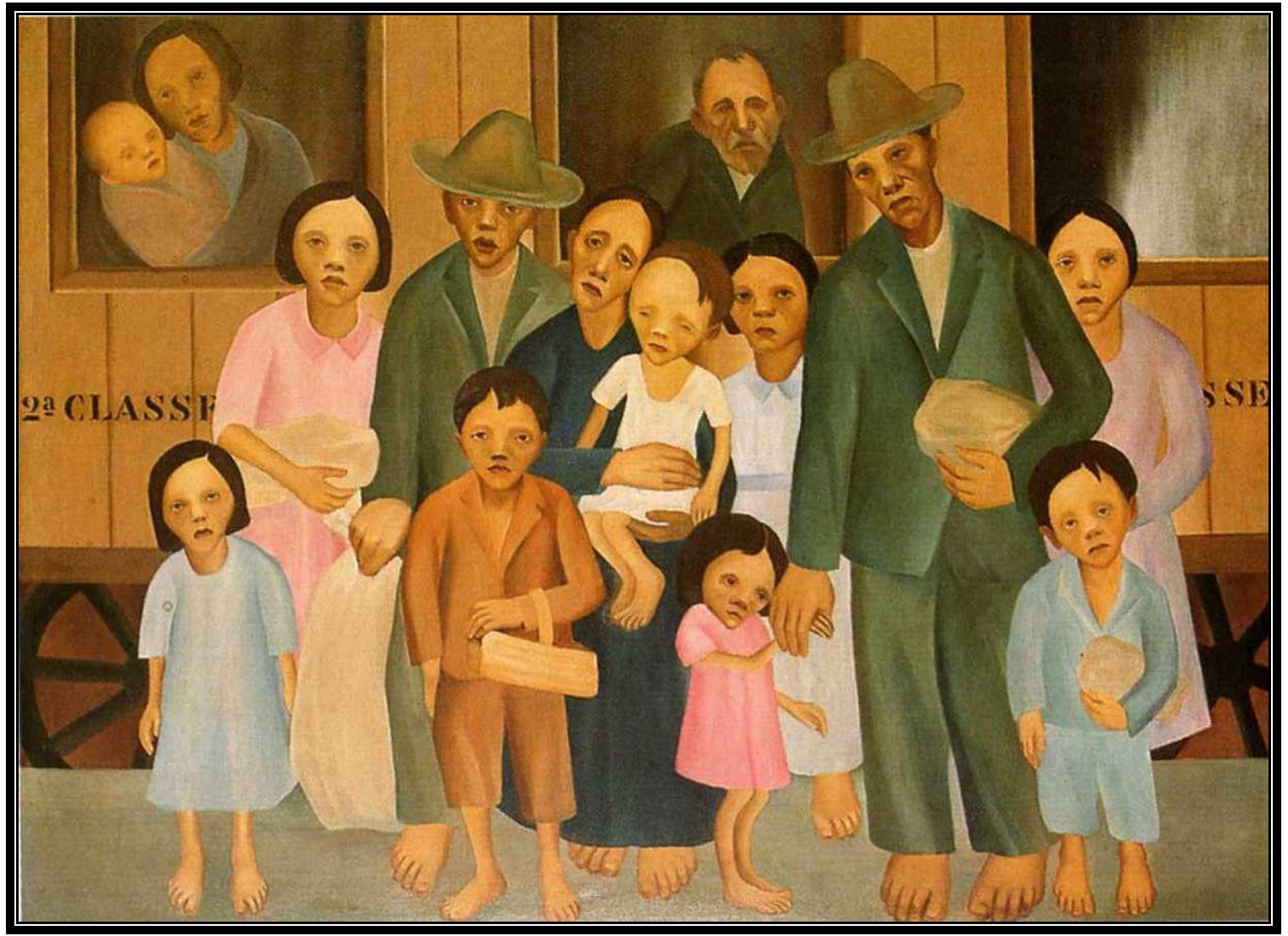

Segunda Classe (1933)

Tarsila do Amaral 
UNIVERSIDADE DE SÃO PAULO

FACULDADE DE FILOSOFIA, LETRAS E CIÊNCIAS HUMANAS

DEPARTAMENTO DE GEOGRAFIA

PROGRAMA DE PÓS-GRADUAÇÃO EM GEOGRAFIA HUMANA

SUELI DE CASTRO GOMES

\section{O Território de Trabalho dos Carregadores Piauienses no Terminal da CEAGESP: Modernização, Mobilização e a Migração}

Tese de Doutorado apresentada ao Programa de PósGraduação em Geografia Humana, Departamento de Geografia, Faculdade de Filosofia, Letras e Ciências Humanas - USP, para obtenção do título de Doutor em Geografia Humana, sob a orientação do Prof. Dr. Heinz Dieter Heidemann.

São Paulo

2007 
Serviço de Biblioteca e Documentação da Faculdade de Filosofia, Letras e Ciências Humanas da Universidade de São Paulo

Gomes, Sueli de Castro.

O território de trabalho dos carregadores piauienses do Terminal da CEAGESP modernização, mobilização e a migração de nordestinos para São Paulo / Sueli de Castro Gomes ; orientador Heinz Dieter Heidemann. -- São Paulo, 2007.

$280 \mathrm{f}$.

Tese (Doutorado - Programa de Pós-Graduação em Geografia Humana. Área de concentração: Geografia Humana) - Departamento de Geografia da Faculdade de Filosofia, Letras e Ciências Humanas da Universidade de São Paulo.

1. Mobilidade no trabalho - São Paulo (SP) 2. Migração urbana (Aspectos sócioeconômicos). 3. Mobilidade social. 4. Economia urbana. 5. Piauienses - São Paulo (SP). 6. CEAGESP. 7. Modernização. I. Título. II. Subtítulo. 
Dedico este trabalho a minha mãe Sonia, meu pai, Sidney (in memorian) e ao meu marido, Ary de Araujo Rodrigues Junior, pelo apoio e carinho que recebi nessa travessia. 


\section{AGRADECIMENTOS}

Muitas pessoas contribuíram direta ou indiretamente com esta pesquisa. Não sei se conseguirei relacionar todos. Contudo, alguns nomes devem ser citados. A todos, os meus agradecimentos.

Ao Prof. Dr. Heinz Dieter Heidemann, que acreditou nessa pesquisa, e me deu a oportunidade e autonomia para o seu desenvolvimento. Desejo aqui ressaltar a importância, não só de sua orientação, mas também, da sua presença no trabalho de campo.

Ao Prof. Dr. Manuel Seabra, que participou dessa pesquisa em diversos momentos: trabalho de campo, Exame de Qualificação e, por fim, com uma leitura cuidadosa e crítica dessa pesquisa, assumindo a co-orientação, extra oficial, o que resultou no enriquecimento do trabalho final.

À Prof. Dra Margarida Maria de Andrade, pelas sugestões durante o Exame de Qualificação e também pela orientação no que diz respeito a cartografia.

Em especial, agradeço a alguns mestres da minha vida escolar, que me sensibilizaram para os caminhos do conhecimento e do saber, quero compartilhar esse monento e tecer uma breve homenagem aos educadores: Nídia Nacib Pontuska, Eulina P.Lufti, Mansur Lufti, Circe Bittencourt e a professora Luisa.

Pela leitura atenta e competente das primeiras versões, trazendo contribuições e preocupações, tanto no campo teórico como na apresentação formal, agradeço ao amigo, piauiense, Vicente Eudes de Souza Alves e a amiga baiana, Ely Souza Estrela.

À amiga Neusa, que acompanhou toda a minha jornada de pesquisa, trocando experiências, angústias, incertezas, auxiliando nas mais diversas e árduas tarefas que a pesquisa exige, os meus agradecimentos.

Não posso deixar de mencionar os amigos dos grupos de estudo do Laboratório de Geografia Urbana que contribuíram com diversas sugestões e reflexões que permitiram a pesquisa avançar: Anselmo, Bete, Conceição, Carlão, Caio, Carol, Cássio, Débora, Erick, Flávia, Izildo, Paulo e Wallace.

Agradeço também aos colegas que me trouxeram pequenas dicas e apoios de grande contribuição: Luciana e Luciano Legaspe (geógrafos que trabalham na CEAGESP); os baianos, Oflávio e Cidálio (os companheiros de militância) e Edson Captâneo e Prof. Dr. Alfredo P. Queiroz Filho (orientação no trabalho cartográfico). 
Foi fundamental para o término da pesquisa, a participação de algumas pessoas que contribuíram com a elaboração cartográfica: Wagner Fernandes e Rinaldo Gomes Pinho; e com a revisão do texto: André Carrasco , Cássio Boechat e Virgínia B. Boechat.

Ào Sr. Carmo Rubilota Zeitune, Direção da CEAGESP, pela colaboração e acesso aos dados cadastrais censitários dos carregadores do Entreposto, o meu agradecimento.

A minha gratidão em especial aos nordestinos que ajudaram o desenvolvimento da pesquisa, como Assisão de Taperoá, o "embaixador da comunidade nordestina", que me apresentou à Diretoria do Sindicato dos Carregadores. Ao presidente do Sindcar, Zé Pinheiro, pela atenção dispensada, e a todos os carregadores que me concederam o seu tempo respondendo às minhas indagações. A todos que, com seus depoimentos me permitiram a realização desta pesquisa. Aos funcionários da CEAGESP e do Jornal Entreposto que auxiliaram e contribuíram para a realização da tese.

Ao CNPQ pelo apoio financeiro viabilizando a realização desta pesquisa.

A todos os funcionários da Pós-Graduação em Geografia da FFLCH, Laboratório de Geografia Urbana e das Bibliotecas, a minha gratidão e, em especial, a Jurema Navarro, que emprestou a sua monografia de graduação sobre a CEAGESP, para o enriquecimento dessa pesquisa.

Lembro-me aqui dos meus colegas e alunos da Uni'Santana e Faculdades Teresa Martin pela solidariedade, compreensão e apoio, mesmo nos mais difíceis momentos que passamos juntos; e ainda de todos que me acompanharam na "sopa de cebola" na CEAGESP e, em especial, dos amigos Roberto e Magali.

Pelo estímulo, colaboração e apoio, agradeço à minha mãe, Sonia, sempre presente em todas fases da minha formação e nessa pesquisa em especial. Aos meus sogros Alayde e Ary e à minha afilhada Flora, bem como, a todos os meus familiares, pela paciência com que me acompanharam nessa etapa da minha vida.

Ao meu marido, Ary de Araujo Rodrigues Junior, o meu maior incentivador, auxiliando desde a logística necessária para o desenvolvimento dessa pesquisa até no trabalho de campo no Mercado do Peixe, nas madrugadas paulistanas.

A todos que, de uma maneira ou outra colaboraram para que este trabalho se tornasse possível e com quem partilho a alegria de ter vencido mais esta etapa. 


\section{SUMÁRIO}

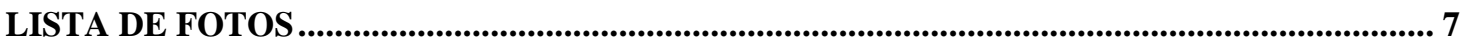

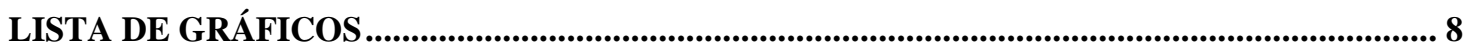

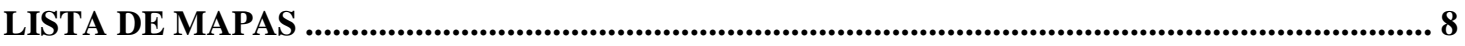

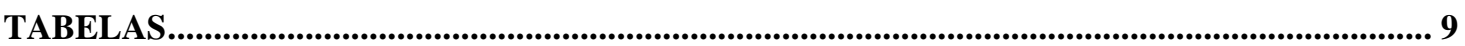

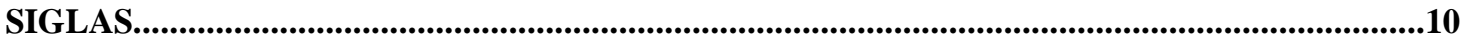

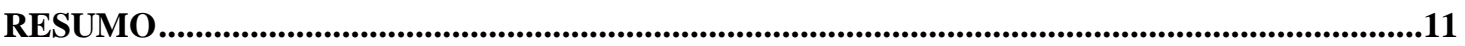

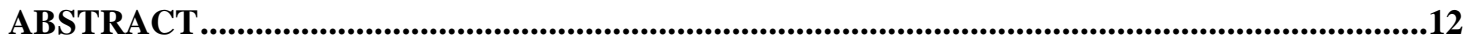

INTRODUÇÃO

1."BANDEIRANTES ÀS AVESSAS" - A MIGRAÇÃO DE NORDESTINOS PARA A GRANDE

SÃO PAULO .26

1. 1. UMA APROXIMAÇÃO À QUESTÃO DA MIGRAÇ̃̃O NORDESTINA: POLÍTICAS PÚBLICAS E A QUESTÃO

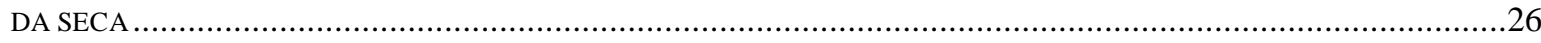

1. 2. O PROCESSO DE MOBILIZAÇÃo DOS NORDESTINOS PARA SÃo PAULO ……………………….......33

1.3 O TERRITÓRIO NORDESTINO EM SÃO PAULO ………………………….....................................4

2. FRUTAS, FLORES, VERDURAS E BAIÃO DE DOIS ............................................................70

2.1. A CEAGESP: UMA HISTÓRIA DE MOBILIDADE E METAMORFOSE ……………….........................70

2.1.1 A ORGANIZAÇÃO, O FUNCIONAMENTO E A IMPORTÂNCIA DA CEAGESP....................................83

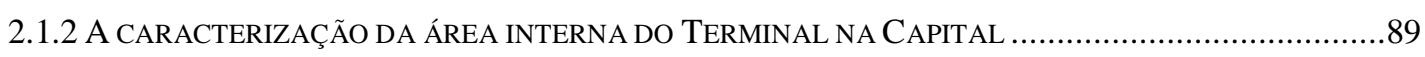

2.1.3 O ENTORNO DO TERMINAL E OS VESTÍGIOS DA MIGRAÇão .........................................................99

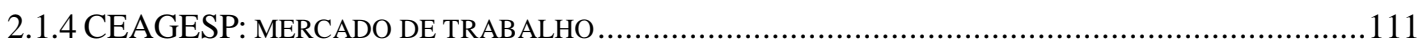

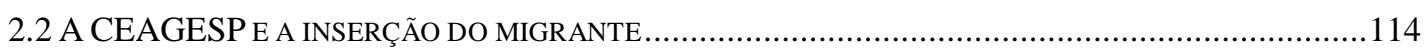

3. OS CARREGADORES DO ENTREPOSTO: TERRITÓRIO DOS PIAUIENSES..............118

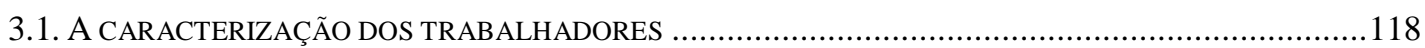

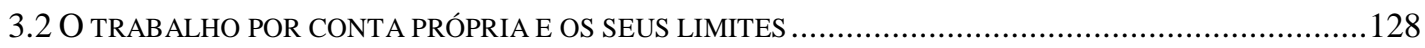

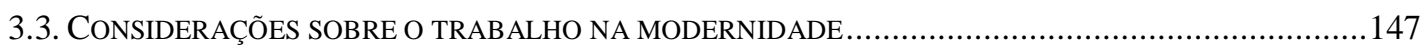

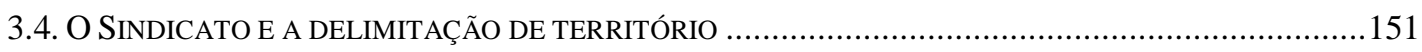

3.4.1. O CLANDESTINO, O TRABALHO INFANTIL E A ESCOLA NOSSA TURMA ......................................164

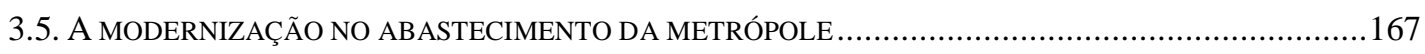

3.5.1. A REESTRUTURAÇÃO NA CIRCULAÇÃO DOS PRODUTOS ALIMENTíCIOS......................................169

3.5.2. CHEGAM AS EMPILHADEIRAS E A BUSCA DA QUALIFICAÇãO ............................................... 174

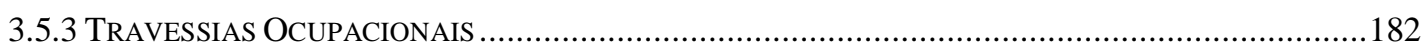

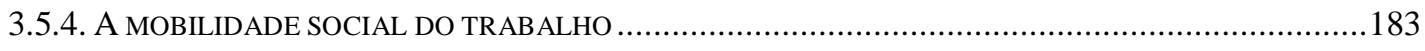

3.6. O CARREGADOR DA CEAGESP SOB OS CIRCUITOS DA ECONOMIA URBANA..................................186 
4.1. AS REDES SOCIAIS E O TERRITÓRIO DE TRABALHO E MORADIA …….........................................198

4.2 A REDE SOCIAL EM OUTROS INTERSTÍCIOS: AS CAFEZEIRAS …..................................................20

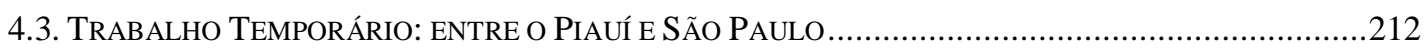

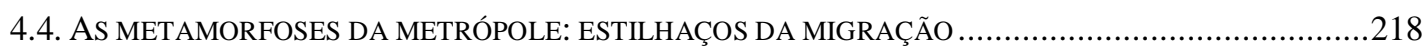

4.4.1. OS ESTILHAÇOS DE UM ESPAÇO FRAGMENTADO - ENTRE A PROSTITUIÇÃO, OS JOGOS E O TRÁFICO

4.5 O TERRITÓRIO E A MULTITERRITORIALIDADE NO TERMINAL DA CEAGESP ................................223

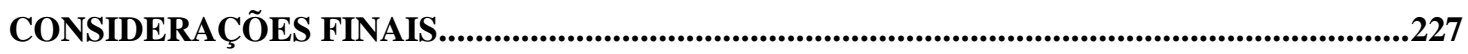

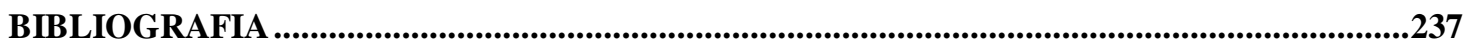

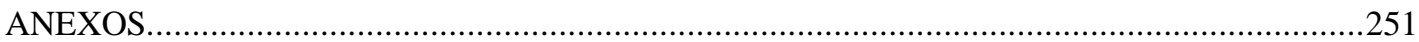


1. Entrada de Imigrantes e Nacionais em São Paulo entre 1870 e 1901.................... 252

2. Roteiro das Migrações para o Estado de São Paulo............................................... 253

3. Pontos de referência: migrantes nordestinos em São Paulo................................... 254

4. Participação dos Migrantes Nordestinos na R.M.S.P, 2000................................. 255

5. Área de Expansão da Migração Nordestina no Estado de São Paulo.1986-1991 e 256 1991-1996.

6. Proporção da Migração Nordestina no total do Movimento Migratório 256 Interestadual.

7. Divulgação dos 40 anos da CEAGESP................................................................. 257

8. Samba-Enrêdo Acadêmicos do Tucuruvi............................................................. 258

9. Destinos das Mercadorias (Região, Estado, Mercosul)........................................ 259

10. Estados da Região Sudeste de Destino das Mercadorias...................................... 259

11. Regiões e Municípios do Estado de São Paulo de Destino das Mercadorias........ 260

12. Destino das Mercadorias por Zonas e Municípios da Região Metropolitana....... 260

13.Destino das Mercadorias Comercializadas segundo a natureza do Destinatário.. 261

14. Destino das Mercadorias Comercializadas segundo o Tipo de Carga............... 261

15. Origem das Mercadorias Comercializadas, segundo o tipo de Carga.................. 262

16. Veículos de Transporte Utilizados pelos Usuários............................................... 262

17. Relação de Ambulantes - Total de Permissionários por Pavilhão....................... 263

18.Relação de Documentos Solicitados pela CEAGESP - Ambulantes.................. 264

19. Ficha de cadastro do Carregador Autônomo ........................................................ 263

20. Faixa Etária dos Carregadores do Terminal da CEAGESP................................. 265

21. Idade dos Carregadores do Terminal da CEAGESP......................................... 266

22. Escolaridade dos Carregadores do Terminal da CEAGESP(2006)................... 267

23. Dados Estatísticos de Comercialização (2005-2006).......................................... 268

24. Data de Entrada dos Carregadores na CEAGESP (2006)................................ 269

25. Participação dos Carregadores por período de Inserção na CEAGESP (2006)... 270

26. Cordel - O Permissionário............................................................................. 271

27. Estado de Origem dos Carregadores (2006).................................................... 272

28. Origem dos Carregadores por Município no Piaú́............................................. 273

29. Origem dos Carregadores por Município no Ceará............................................ 274

30. Município de Residência dos Carregadores da CEAGESP............................... 275

31. Distritos de residência dos Carregadores no município. de Osasco................... 276 


\section{LISTA DE FOTOS}

F. 1: Vapor no Rio São Francisco 42

F. 2: Estação de Trem de Pirapora 42

F. 3: Estação do Brás

F. 4: Hospedaria do Migrante 43

F. 5: Comércio do Brás com a imagem do Pe. Cícero 47

F. 6: Rua do Forró

F. 7: Centro das Tradições Nordestinas

F. 8: A construção do CEASA 72

F. 9: Vista Panorâmica da CEAGESP 91

F. 10: Relógio Central

F. 11: Mercado do Peixe $\quad 91$

F. 12: Pavilhão (MLP) comercializando Verduras 94

F. 13: Feira de Flores (MLP) 94

F. 14: Favela do Jaguaré 108

F. 15: Panorâmica da Caixaria e o Terminal 108

F. 16: Caixaria e a Verticalização da Vila Leopoldina 109

$\begin{array}{ll}\text { F. 17: Caixaria } & 109\end{array}$

F. 18: Moradores de Rua $\quad 110$

F. 19: Catador de Alimentos $\quad 110$

F. 20: Placa de Aviso aos Ambulantes 110

F. 21: Carregadores do setor geral 136

F. 22: Carregador das Flores 136

F. 23: Carregador do Pescado 136

F. 24: Carregador do Pescado 136

F. 25: Galpão dos Carregadores 153

F. 26: Galpão dos Carregadores 153

F. 27: Faixa anunciando evento 153

F. 28: Movimento dos Carregadores 154

F. 29: Greve dos Carregadores $\quad 154$

F. 30: Presidente do Sindicato 155

F. 31: Frei Damião 155

F. 32: Missa $\quad 158$ 
F. 33: Santa Luzia 158

F. 34: Fiscalização 166b

F. 35: Clandestino 166b

$\begin{array}{ll}\text { F. 36: Empilhadeira } & 178\end{array}$

$\begin{array}{ll}\text { F. 37: Empilhadeira no setor das frutas } & 178\end{array}$

F. 38: Casa do Norte no setor de Diverso 195

F. 39: Casa do Norte 195

F. 40: Atacadista e empregado piauienses 204

\section{LISTA DE GRÁFICOS}

Gráfico 1: Migrantes Interestaduais, segundo Local de Origem (em \%) 60

Gráfico 2: Migrantes Interestaduais, segundo Local de Origem (em\%) 60

Gráfico 3: Faixa Etária dos Carregadores do Terminal da CEAGESP 120

Gráfico 4: Escolaridade dos Carregadores do Terminal da CEAGESP 123

Gráfico 5: Comercialização em Toneladas do Entreposto e Terminal de 125

São Paulo e Terminal de São Paulo em 2005 e 2006 (CEAGESP)

Gráfico 6:Região de Origem dos Carregadores 190

Gráfico 7: Estado de Origem dos Carregadores $\quad 190$

\section{LISTA DE MAPAS}

Mapa 1: Migrantes Nordestinos no Município de São Paulo 58

Mapa 2: Região da Grande São Paulo - Participação dos Nordestinos na 65

População total do Município (2000)
Mapa 3: Região da Grande São Paulo - Migrantes Nordestinos por Município

Mapa 4: CEAGESP na Metrópole de São Paulo 85

Mapa 5: A CEAGESP (2007) 97

Mapa 6: A CEAGESP e o seu Entorno 105

Mapa 7: Origem dos Carregadores por Município dos Estados do Piauí e Ceará 191

Mapa 8: Principais Municípios de Origem dos Carregadores dos Estados do 192

Piauí e Ceará

Mapa 9: Região da Grande São Paulo - Município de Residência dos 205

Carregadores

Mapa 10: Município de Osasco -Distritos de Residência dos Carregadores 206 


\section{TABELAS}

Tab. 1: Quadro das Secas Ocorridas no Nordeste 32

Tab. 2: Origem e Residência do Migrante 56

Tab. 3: Migrantes Nordestinos na Metrópole da Grande São Paulo - 2000

Tab. 4: Resumo dos horários de comercialização praticados no ETSP de 1966 a 76 2006

Tab. 5: Quantidades Anuais dos Produtos Hortifrutigranjeiros e Pescados no ETSP 77

Tab. 6: Resumo das Quantidades e em notas, por Via de Acesso a São Paulo 86

Tab. 7: Horários de Vendas no Atacado 90

Tab. 8: Número de Ambulantes Cadastrados 116

Tab. 9: Volume Comercializado em Toneladas 168 


\section{SIGLAS}

APAS - Associação Paulista de Supermercados

ANESP - Associação de Nordestinos do Estado de São Paulo

BNDES - Banco Nacional de Desenvolvimento Econômico e Social

CEAGESP - Companhia de Entreposto e Armazéns Gerais do Estado de São Paulo

CEASA - Centro Estadual de Abastecimento S.A.

CGN - Galli Construtora e Incorporadora

CLT - Consolidação das Leis do Trabalho

CPTM - Companhia Paulista de Trens Metropolitanos

$\mathrm{CQH}$ - Controle de qualidade de Hortifrutigranjeiros

CTB - Centro de Tradições Brasileiras

CTN - Centro de Tradições Nordestinas

CIAP - Central Integrada de Abastecimento de São Paulo

DEIC - Delegacia de Investigações sobre o Crime Organizado

DIEESE - Departamento Intersindical de Estatística e Estudos Socioeconômicos

DNOCS - Departamento de Obras Contra Seca

ETSP - Entreposto Terminal do Estado de São Paulo

FAC - Fundo de Amparo ao Carregador

FAPESP - Fundação de Amparo à Pesquisa do Estado de São Paulo

FIEO - Faculdades Integradas de Ensino de Osasco

IBGE - Instituto Brasileiro de Geografia e Estatística

INSS - Instituto Nacional do Seguro Social

IPEA - Instituto de Pesquisa Econômica Aplicada

ISS - Imposto sobre Serviço

LABUR - Laboratório de Urbana

PNAD - Pesquisa Nacional por amostra de Domicilio

PED - Pesquisa de Emprego e Desemprego

PSDB - Partido da Social Democracia Brasileira

PT - Partido dos Trabalhadores

SDS - Social Democracia Sindical

SEADE - Fundação Sistema Estadual de Análise de Dados

SINDCAR - Sindicato dos Carregadores

SUDENE - Superintendência do Desenvolvimento do Nordeste

SPR - São Paulo Railway

UNICAR - União dos Carregadores 


\section{RESUMO}

O objeto da pesquisa é o estudo da mobilidade do trabalho em suas diferentes formas no processo de modernização, no qual a rede social aparece como um produto e suporte de desencadeamento. Para tal, estudamos a migração de nordestinos para a metrópole de São Paulo e em especial uma grande rede social de piauienses. Esse último grupo de migrantes nordestinos vai se inserir no mundo do trabalho na condição de carregadores no terminal de abastecimento da Grande São Paulo. Assim, esses nordestinos demarcam a sua territorialidade, expressa na relação de trabalho, na sua origem e na sua residência.

A Companhia de Entrepostos e Armazéns Gerais do Estado de São Paulo - CEAGESP - possui entre outros equipamentos um entreposto terminal de produtos hortifrutigranjeiros e pescado. Este entreposto está instalado desde 1966 na Vila Leopoldina, localizado na Zona Oeste da cidade de São Paulo. Ele é um grande mercado de trabalho, em que a mobilidade do trabalho está materializada sob diversas formas ocupação tanto na área interna, como no seu entorno. As formas de trabalho desse Mercado estão inseridos nos dois circuitos da economia urbana.

Palavras-Chave:

Migração - Nordestinos - CEAGESP - Redes Sociais - Trabalho - Mobilidade do Trabalho 


\begin{abstract}
This research aims at studying the labor mobility in its different forms within the modernization process, in which the social network appears as its product and also as a ground for its development. Thus, we exam the migration of Brazilian Northeastern people to the city of São Paulo, more specifically those from the State of Piauí. Members of this group tend to introduce themselves in the labor market in the condition of carriers in the São Paulo metropolitan supplying terminal, known as CEAGESP. By that, these migrants define their territoriality, expressed in the labor relationships they establish in their origin places as well as in their local residences.

The State of São Paulo General Mart and Warehouse Company - CEAGESP - has among other equipments a commercialization terminal of vegetables, fruits, and fish and poultry products. This mart has been installed at Vila Leopoldina since 1966, located in the West Zone of the city of São Paulo. Also, it constitutes an immense "labor market", where the labor mobility is materialized under various occupation forms, be it in its internal area or in its surroundings. The labor forms of this market are inserted in both the urban economy circuits.
\end{abstract}

Key-Words:

Migration - Northeastern migrants - CEAGESP - Social Networks - Labor - Labor Mobility 


\section{INTRODUÇÃO}

Em pesquisas anteriores, reunidas na Dissertação intitulada Do comércio de retalhos à feira da sulanca: uma inserção do migrante em São Paulo (2002), desenvolvidas no mestrado sob a orientação do Prof. Heinz Dieter Heidemann, estudamos o comércio de retalhos como uma das formas de inserção do migrante nordestino na metrópole de São Paulo. Naquele momento, foi realizada uma pesquisa sobre o fluxo de sua migração para São Paulo sob vários aspectos, o que permitiu a realização das primeiras leituras que abordam o tema. Durante o trabalho de campo, quando buscávamos elementos que evidenciassem a presença nordestina na cidade, estabelecemos contato com pessoas que nos levaram a uma outra área de grande concentração desses migrantes, o Terminal de Abastecimento da Metrópole, conhecido como CEAGESP.

Em 1986, quando cursava no segundo ano de graduação de Geografia, iniciei também a minha carreira como professora na rede pública, no município de Osasco, distrito de Munhoz Junior. Simultaneamente, assistia uma disciplina optativa chamada Iniciação à Pesquisa, ministrada pelo Prof. Gil Sodero de Toledo. Naquela matéria devíamos escolher um tema para desenvolver uma pesquisa; não tive dúvidas, então em escolher aquela realidade que a sala de aula manifestava, em Munhoz Júnior. Lembro-me das primeiras leituras que o professor Gil me indicava como, A geografia do aluno Trabalhador, de Márcia Spyer Resende (1986). Chegamos até a fazer um trabalho de campo, acompanhados pelo professor, porém a minha imaturidade intelectual naquela ocasião fez com que eu não prosseguisse com a disciplina e abandonasse o projeto. No entanto, continuei a lecionar para aqueles migrantes e filhos de migrantes. Depois da escola de Munhoz Junior, dei aulas no ano seguinte no Jardim Helena Maria, depois, em Rochdale, ${ }^{1}$ e no curso noturno da EEPG Maria Eugênia, escola mais próxima da favela Nova Jaguaré.

Já nesta pesquisa atual, ao realizar as entrevistas com os carregadores, perguntei sobre o local de suas residências e, para a minha grata surpresa, a maior parte se identificou como morador de Munhoz Junior, Helena Maria, Rochdale ou áreas próximas. Imediatamente, eatabeleci uma identificação me com eles, como ex-professora daquelas comunidades. As referências sobre minhas atividades docentes nas localidades trouxeram certa relação de confiança entre os entrevistados comigo e essa aproximação permitiu maior fluidez nas

\footnotetext{
${ }^{1}$ Distritos do município de Osasco.
} 
entrevistas. A tabulação dos dados cadastrais confirmou também essa coincidência de percursos e me deu a sensação de continuidade, nesse momento ao projeto que tinha ficado pendente, fechando um círculo, uma etapa. A sala de aula é o local onde acontecem os primeiros contatos do professor com a migração, os filhos do migrante e toda a problematização que gira em torno dessa população, uma delas, a questão do trabalho e de sua inserção. Assim, o meu percurso é semelhante ao de muitos educadores-pesquisadores que despertam para esse assunto e buscam, na universidade, um caminho para as suas indagações.

Esta pesquisa tem como objetivo analisar o processo de mobilidade do trabalho, tendo como referência empírica o trabalho do carregador presente nos interstícios do Centro de Abastecimento da Grande São Paulo, serviço assumido principalmente por migrantes nordestinos. Essa investigação estudou esse trabalho que permitiu a inserção do migrante na vida econômica da metrópole, no processo de reorganização e reprodução desse espaço metropolitano. O local do Centro de Abastecimento é abordado como um grande mercado de trabalho, o que nos conduziu a diversas indagações, estimulando o desenvolvimento desta pesquisa, sobre a presença do migrante nordestino na CEAGESP - Companhia de Entreposto e Armazéns Gerais do Estado de São Paulo.

Os dados do censo demográfico de 2000, divulgados pelo $\mathrm{IBGE}^{2}$, registram a presença de 3.641.148 de nordestinos, que representam $20 \%$ da população da região metropolitana de São Paulo. Para nossos estudos, consideramos a presença nordestina muito além, do grupo de migrantes recém-chegados ${ }^{3}$, como todo o conjunto de populações de origem nordestina ${ }^{4}$, incluindo seus descendentes, que mantêm ainda manifestações da cultura de seus pais, mesmo que de forma residual. Percebendo a dimensão da presença nordestina na metrópole, escolhemos abordar, então, a sua inserção, em um de seus espaços de concentração - o Terminal ou Entreposto de Abastecimento em São Paulo.

A Pesquisa de Emprego e Desemprego (PED), realizada pela Fundação SEADE e DIEESE para a Região Metropolitana de São Paulo mostra o índice de 15,3\% de

\footnotetext{
2 Fonte: Folha de São Paulo,de 22.08.96. Informa que no PNAD de 1993, eram 3.039.861 nordestinos, considerando o município de nascimento.

${ }^{3}$ O IBGE considerou em sua coleta da informação pessoas não residentes no município em 01/09/1991, com 4 anos de idade ou mais, para o censo de 2000.

${ }^{4}$ Consideramos nessa pesquisa os nordestinos provenientes de nove estados que compõem a região nordeste delimitada pelo IBGE. Entretanto, não devemos deixar de considerar os mineiros que foram mobilizados pelos mesmos processos que os nordestinos, envolvidos também pelas políticas públicas de mobilização. As correntes de nordestinos e mineiros faziam o mesmo trajeto para chegar em São Paulo. Dados do censo de 1980 registravam os mineiros (1674.021) com a maior participação na migração, seguidos dos baianos (1060359), paranaenses (715741) e pernambucanos (715.343). Fonte: O Estado de São Paulo, 20.03.82. Na RMSP há uma grande participação de mineiros; do total de migrantes oriundos de outras Unidades da Federação entre 19952000, 72,8\% eram nordestinos, principalmente baianos $(29,1 \%)$, pernambucanos $(14,1 \%)$, seguidos dos mineiros, 10,2\% de participação no fluxo de migrantes (Fonte: SEADE 2003)
} 
desempregados, no mês de fevereiro de 2007, o que significa um contingente estimado em 1.546 mil pessoas. Nesse total está contido o chamado desemprego oculto pelo trabalho precário $^{5}$. Também, há os processos de modernização, que transformam o trabalho e produzem o chamado desemprego estrutural, afetando todos os países e produzindo um grande número de desempregados ${ }^{6}$. Portanto, discutir e pensar a temática do trabalho é imprescindível para a sociedade.

A Grande São Paulo vem passando por profundas transformações, nos últimos anos, quando o setor industrial aos poucos está sendo substituído pelos setores de serviços e comércio, como atividade de maior importância na metrópole. Os estudos de Sandra Lencioni (1991) mostram a expansão da metrópole e inclui entre suas implicações a redução do número de empregos. Em sua pesquisa encontramos uma redução de 144 mil postos de trabalho, seguindo a reestruturação da indústria. Tais mudanças afetam bastante o mercado de trabalho. Paul Singer afirma: "Os mercados do trabalho informal são o desaguadouro de toda força de trabalho que desistiu de procurar emprego ou deixou de contar com suporte material para fazê-lo." (SINGER, 2000:12).

Nesse contexto de redução de emprego, os primeiros a serem atingidos são os migrantes; no caso da Grande São Paulo, são os nordestinos, que têm a sua maior participação entre os migrantes. Vejamos o que a pesquisa do IPEA constatou:

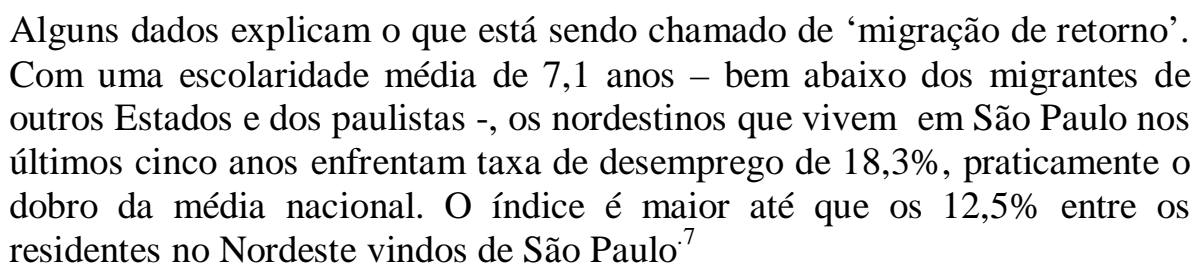

Depois de serem mobilizados para o centro econômico da metrópole paulista, eles novamente são mobilizados para retornarem para a sua área de origem, ou ocuparem uma outra forma de trabalho mais precarizada, seguindo a lógica do capital. Tal cenário mostra como é pertinente o estudo das formas de trabalho que giram em torno do Centro de Abastecimento Alimentício da Metrópole, também, por isso escolhemos estudar o trabalho do carregador, no sentido de perceber a mobilidade e a metamorfose do trabalho, no processo de desenvolvimento do capital. Esse objeto nos conduziu a aprofundar e avançar os estudos sobre migração e trabalho, ou, melhor dizendo, a mobilidade do trabalho.

\footnotetext{
${ }^{5}$ Essa é a denominação adotada pela Fundação SEADE e DIEESE. A denominação mais adequada para nossos estudos seria o trabalho precarizado ,pois remete ao processo que leva às atividades desregulamentadas e sem garantias trabalhistas. Fonte: www.seade.gov.br acesso em 07 de abril de 2007.

${ }^{6}$ Alguns autores tratam dessa problemática como KURZ (1996) e ANTUNES (2000).

${ }^{7}$ Folha de São Paulo, 23 de abril de 2006.
} 
O trabalho do carregador não é novo, mas seu significado, assim como outras atividades do terminal antes invisíveis, passa a ser percebido pelos estudiosos e constitui-se o centro de nossa investigação. VAINER (2005) abre caminhos para entendermos o porquê da escolha de estudar o universo do trabalho no carregador no Entreposto de Abastecimento. Quando levanta o motivo de se estudar o trabalho precarizado, vejamos o que diz:

Evidentemente, esse trabalhador existe desde a origem do capital, e esteve
presente ao longo de toda sua história; durante longo tempo, porém ocupou o
que designei de zona de sombra, zona não reconhecível pelo quadro teórico
conceitual, configurando um ponto cego da teoria. A generalização e a
intensificação deste tipo de relação, sua (re) incorporação às práticas de
segmentos do capital, normalmente qualificados de avançados, conferiram-
lhe um significado prático e uma densidade teórica que lhe tinham sido
recusados por muito tempo. A nova visibilidade deste tipo de relação de
trabalho contribui para que conquistasse, ou melhor, recuperasse, o direito de
cidadania teórico-conceitual. Assim, ganha ares de novidade a mobilidade do
trabalho, que desde Marx, como brilhantemente expôs Gaudemar (1976), foi
identificada como atributo e forma de existência do trabalho sob o capital.
Que isto ocorra sob o nome de flexibilidade não altera em nada a constatação
de quão tardia é, em certas escolas e correntes de pensamento, a descoberta
desta dimensão fundamental das relações de trabalho que estruturam a
sociedade moderna: o trabalho móvel, mobilizável, mobilizado e também, às
vezes, imobilizado. (VAINER,2005:254-255).

Nesse sentido, nossa referência teórica inicia-se com a leitura de Gaudemar (1977) acerca da mobilidade do trabalho, cujo enfoque está na produção e na circulação da força de trabalho, pois essa proposição contribui para o entendimento da migração de nordestinos para São Paulo, assim como outras mobilidades a que esse grupo está sujeito. O processo de produção capitalista aqui é viabilizado na medida em que ocorre o deslocamento espacial, sobretudo dos nordestinos para São Paulo. Esse grupo ajudou também a formar um excedente de mão-de-obra denominado, no passado, por muitos autores marxistas, como um exército industrial de reserva. Na leitura dos marxistas, esse exército pressionava para baixo os salários, seguindo a lei da oferta e da procura.

Jean Paul Gaudemar elabora a teoria da mobilidade do trabalho a partir das análises de Marx sobre a reprodução do capital. Na lógica desse sistema reprodutivo, que busca cada vez mais reproduzir valor, o capital serve-se dos corpos dos trabalhadores. Tal construção teórica é realizada, também, a partir das leituras de Foucault, quando este disserta acerca do poder como referência teórica para a compreensão do significado da entrega dócil dos corpos dos homens submetidos ao poder do capital.

Assim, o capital mobiliza um exército de reserva de homens para a sua reprodução, o que explica os deslocamentos populacionais, os grandes fluxos de pessoas que buscam no processo de modernização melhores condições de vida. A mobilidade do trabalho não se 
restringe aos deslocamentos espaciais, isto é, não diz respeito somente às migrações, mas refere-se também a outras formas de mobilidade, como a social e setorial. O tão corrente termo, pós-fordismo, sobre a flexibilidade do trabalho, nada mais é do que um desígnio das formas de mobilidade do trabalho para a ampliação do capital. $\mathrm{O}$ uso desse conceito de mobilidade do trabalho só tem significado como categoria historicamente determinada, compondo o processo de modernização ${ }^{8}$, assim como, o conceito do próprio trabalho ${ }^{9}$

Quando dimensionamos o contexto em que os nordestinos estão inseridos, vemos as condições políticas, econômicas e sociais que privam grande parcela da população de elementos vitais para sua sobrevivência. Constatamos que a migração é uma mobilidade forçada, e usada como estratégia pelo capital para a sua reprodução. O capital acaba designando a esse grupo, as áreas de destino, ou os chamados pólos de atração, que no caso em estudo é São Paulo, e, mais especificamente, o mercado de trabalho do Terminal da CEAGESP. A mobilidade do trabalho no Entreposto está presente nas diversas formas que tal categoria abrange: mobilidade social, mobilidade nos ofícios entre os circuitos da economia urbana, entre o trabalho clandestino e o regulamentado, na migração temporária e na migração regional.

Para Gaudemar $(1977,17)$ : “toda estratégia capitalista de mobilidade é igualmente de mobilidade forçada." Essa coerção manifesta-se ao estudarmos o processo de formação econômica do espaço brasileiro e a reprodução ampliada do capital; podemos compreender a presença maciça dos nordestinos na metrópole de São Paulo. As leituras de Oliveira (1981) e Singer (1973) vinculam o exército de reserva e a mobilidade territorial ao desenvolvimento desigual e combinado das regiões Centro-Sul e Nordeste ${ }^{10}$. O fluxo migratório se intensifica com a mudança das políticas públicas que estimulavam a vinda do migrante nacional para São Paulo e coibiam a migração externa, como confirmam os estudos de Albuquerque Jr. (1990), Vainer (2000) e o depoimento de Jordão Neto (Apud. GOMES, 2002:40).

Existe uma vasta contribuição bibliográfica voltada à compreensão da migração de nordestinos para São Paulo, como as pesquisas de Baptista (1998) que estudou as redes de solidariedade na favela de Paraisópolis, de Albuquerque Jr.(1990), Menezes (1990) e Ramires

\footnotetext{
${ }^{8}$ VAINER, 2005, p. 256.

${ }^{9}$ POSTONE (2000) e KURZ (2000).

${ }^{10}$ Existem outras leituras sobre as diferenças econômicas e sociais entre os espaços ou áreas, de autores como KURZ (1996), POSTONE (2000) e HEIDEMANN (2004), que se utilizam da categoria que se refere à não simultaneidade desses processos em espaços ou áreas diferentes, que se distanciam das categorias como classes sociais, lutas de classes e mesmo exército de reserva para entender esse acumulo do capital, na lógica da mercadoria.
} 
(2001), que estudaram a migração de nordestinos na perspectiva de entender a sua inserção no mercado de trabalho.

Encontramos uma recente literatura na história e na sociologia que recupera o processo histórico dessa migração, desde o fim do séc. XIX, como a pesquisa de Gonçalves (2002), que segundo o autor, se situa no momento do chamado Brasil Moderno, entre as décadas de 30 e 50, com a chegada dos nordestinos na Hospedaria dos Imigrantes, tema também pesquisado por Paiva (2004). Estrela (2003) desenvolve o estudo sobre o fluxo de baianos que migraram para São Paulo e depois retornaram, denominados sampauleiros; a autora registra a saga desses migrantes nas décadas de 50 e 60, desde o trajeto e o transporte até a chegada em São Paulo, propondo uma reflexão sobre o momento do retorno à área de origem. Já Rigamonte (2001) nos conduz com seu olhar da antropologia urbana, apontando a presença nordestina como manchas na metrópole da Grande São Paulo, selecionando para tal dois espaços significativos nessa metrópole.

Procuramos então estudar, portanto, as transformações da metrópole a partir do seu centro de abastecimento; e, particularmente, da inserção de migrantes nordestinos, como trabalhadores do setor informal. O processo de metropolização atraiu muita gente para São Paulo, principalmente migrantes nordestinos, orquestrados pelas políticas migratórias e econômicas. A presença do contingente migratório se faz sentir tanto nas áreas centrais como nas mais periféricas da metrópole, fato já estudado e analisado por diversos estudiosos de São Paulo.

Queremos lembrar que o nosso foco se inside sobre os migrantes inseridos na CEAGESP, não pretendemos, portanto, nesse sentido desenvolver um estudo das transformações da Vila Leopoldina, enquanto distrito; seguindo a sua delimitação oficial, e nem é um estudo de bairro. Nossa área de estudo se delimita a partir da CEAGESP, como espaço mobilizador, como mercado de trabalho. Nesse sentido, compreender o seu entorno se faz necessário, no que se refere aos elementos da paisagem como indicativos da mobilização. Esses elementos podem estar tanto no distrito do Jaguaré, como na Vila Leopoldina. Entendemos que a Vila Leopoldina representa muito mais do que os elementos que destacamos no entorno da CEAGESP, porém, o nosso critério está focado nas atividades que elegemos para este estudo dentro do Terminal da CEAGESP. Assim, nossa seleção de temas está centrada nos indicadores de mobilidade como, o albergue, os moradores de rua, o conjunto habitacional e as favelas.

A CEAGESP localiza-se no distrito da Vila Leopoldina, Zona Oeste de São Paulo. Desde a sua instalação, em 1966, vem alterando o espaço por ela ocupado. O Terminal da da 
CEAGESP da Vila Leopoldina. funciona em uma área de $700 \mathrm{mil} \mathrm{m}^{2}$ e tem um movimento anual de 2,4 milhões de toneladas de produtos, dos mais variados (FSP., 31/03/2002), como frutas, legumes, verduras, peixes e flores ${ }^{11}$, que abastecem $60 \%$ dos comerciantes da Grande São Paulo. No entorno do Terminal da CEAGESP, foram-se formando favelas e diversas atividades, dentre elas as que Milton Santos (1979) chamou de circuito inferior, relacionadas com o Terminal e com um vasto contingente de moradores de rua. Essa população, em parte, alimenta-se do rejeito e faz algum serviço disponível no Entreposto.

Entre as diversas formas de trabalho que ocorrem no espaço interno do Entreposto, destacamos nesta pesquisa, o trabalho dos carregadores, trabalhadores autônomos e regulamentados, pois esses são cadastrados pela administração e formam um grupo de 3405 carregadores. Para melhor caracterizá-los e entendermos os processos em que se inserem nos balizamos principalmente em Reginaldo Prandi (1978) que estudou o trabalho por conta própria. O autor identifica essa forma de trabalho como a que não apresenta vínculo empregatício, a que depende principalmente da força de trabalho e compõe o circuito capitalista de produção.

No processo de modernização, a figura do trabalho autônomo está associada com a do agente poupador e empreendedor, mesmo atualmente, quando as condições necessárias para permitir o acúmulo de um pecúlio como capital inicial se transformou profundamente. Segue o autor:

Na impossibilidade de vir a se transformar em empregador o autônomo traz em si a oportunidade de negar, pelo menos a condição de assalariado. Mas o trabalho por conta-própria significa também a possibilidade de trabalho para os que não conseguem ser assalariados." (PRANDI, 1978:85).

Desse modo, o autônomo carrega em si a negação do assalariamento, o desejo da de uma liberdade por não ter horários nem patrão, mas, por outro lado, essa opção mascará a expulsão da condição de assalariamento. Esse formato de trabalho, que tende a crescer na modernização, acaba sendo estimulado por um discurso que prega o empreendedorismo, mas, na realidade guarda restrições como a ilegalidade, a concorrência, e outras mais, encontrando nelas,também o seu limite.

Com o processo de modernização e o desemprego, houve um aumento no número de pessoas na função de carregador, muito mais do que o necessário. Elevou-se a concorrência entre eles e, conseqüentemente, seus ganhos diminuíram. Segundo a afirmação de um trabalhador : "Existem mais carregadores do que consumidores". Outro problema que os

\footnotetext{
${ }^{11}$ O chamado mercado das flores é visitado, também, por turistas, por conta da sua beleza.
} 
preocupa é a implantação das máquinas empilhadeiras, que podem substituí-los, levando-os a compor o exército de desempregados.

Assim, encontramos uma série de transformações que o processo de modernização e a racionalidade impõem, que modifica e que mobiliza os migrantes. A metrópole se desenvolve combinada com um processo crescente de desemprego estrutural, e nessa simultaneidade aparecem ou ampliam-se formas de trabalho precarizado a que os migrantes nordestinos, dentre outros, se sujeitam.

O abastecimento ocorre em meio ao processo de racionalização, que impõe modificações naquele espaço. As alterações ocorrem também no modo de abastecer a metrópole e circular a mercadoria, o alimento. Cada vez mais as pessoas vão aos supermercados e hipermercados, deixando de frequientar as feiras e quitandas ${ }^{12}$; esse fato justificaria o declínio das vendas na CEAGESP, e a diminuição, da necessidade dos serviços dos carregadores.

O debate sobre o trabalho está na ordem do dia, tanto na academia como no setor público e na sociedade em geral. A discussão sobre mobilidade do trabalho, nos conduziu a estudar a categoria trabalho. Iniciamos nossos estudos a partir de Marx que concebe o trabalho sob o capital. O trabalho realiza a mediação entre a natureza e o homem, transformando-a em mercadoria. O trabalho é a força de trabalho que passa a ter um valor de troca, então, ele é uma forma de mercadoria. Atualmente, existe uma diversidade de enfoques teóricos que buscam fazer uma interpretação da obra de Marx para entender a categoria do trabalho nesse período pós-fordista. Identificamos duas vertentes diferentes que estudam a categoria trabalho. A primeira, parte da leitura de Lucács, e tem no Brasil Ricardo Antunes como um desses autores que ontologizam o trabalho. A segunda vertente considera o trabalho em sua determinação histórica e, portanto não pode esse ser naturalizado, linha em que nos referenciamos em parte, apoiados em Postone (2000) e Kurz (1996). O trabalho não é suprahistórico ou trans-histórico, pois esse só pode ser concebido sob a lógica da mercadoria. Nessa lógica, conseguimos visualizar a sua transformação, ou metamorfose. Desse modo, apesar das duas vertentes divergirem em seu cerne, os estudos da primeira vertente contribuem no sentido de explicitar as metamorfoses que o trabalho sofre no pós-fordismo e assim como para compreendermos os processos que ocorrem com o trabalho no Terminal de Abastecimento da Grande São Paulo.

Assim a nossa trilha de estudos segue em torno da relação trabalho e capital, em que o trabalho é mercadoria. Dessa maneira, se o trabalho é mercadoria, então devemos estudá-lo

\footnotetext{
${ }^{12}$ Cf. CACCIAMALI (1983).
} 
em seus circuitos, e para isto, encontramos a teoria dos circuitos da economia urbana, de Milton Santos (2004 [1979]:37), um referencial teórico significativo. Vejamos como explica o autor:

A existência de uma massa de pessoas com salários muito baixos ou vivendo de atividades ocasionais, ao lado de uma minoria com rendas muito elevadas, cria na sociedade urbana uma divisão entre aqueles que podem ter acesso de maneira permanente aos bens e serviços oferecidos e aqueles que, tendo as mesmas necessidades, não têm condições de satisfazê-las. Isso cria ao mesmo tempo diferenças quantitativas e qualitativas no consumo. Essas diferenças são a causa e o efeito da existência, ou seja, da criação ou da manutenção, nessas cidades, de dois circuitos de produção, distribuição e consumo dos bens e serviços.

A modernização gera dois circuitos que estão intimamente interligados o superior e o inferior pois fazem parte de um único sistema. Essa designação vem superar a visão dual dos circuitos moderno e tradicional, enfatizando o seu comportamento e a sua organização, não a sua idade. Esses circuitos estão em constante transformação, assim como o próprio capital e apresentam uma interdependência.

Entre os trabalhos do circuito inferior, Milton Santos (2004 [1979]:255) cita o de carroceiro, uma espécie de carregador. São serviços que foram fracionados em múltiplas e infinitas tarefas, que absorvem aqueles que são desprovidos de capital e qualificação profissional. Como diz o autor em sua reflexão, "O circuito inferior, por sua capacidade de inchamento, intervém então para absorver o excesso de mão-de-obra”. Identificamos na atividade dos carregadores esse processo de absorção, que chega então ao limite, e o controle é realizado pela Administração e pelo Sindicato, como trataremos no desenvolvimento da pesquisa.

No espaço interno da Companhia encontramos uma enorme rede social de nordestinos, que se inseriram nas diferentes formas de trabalho não regulamentado desse mercado de trabalho. Em meio à diversidade de formas de trabalho que encontramos na CEAGESP, a que mais nos chamou atenção foi a figura do carregador, a atividade cuja expansão foi determinada principalmente pelas redes sociais. Identificamos que uma grande parte dos carregadores da CEAGESP é composta por migrantes oriundos do estado do Piauí. Em geral, eles residem na Grande São Paulo, sobretudo, no município de Osasco ${ }^{13 .}$ Buscaremos em autores como Baptista (2000), Ramella (1995), Gomes (2002), um arcabouço teórico para substanciar-nos no estudo do assunto.

\footnotetext{
${ }^{13}$ Esse deslocamento entre a periferia da metrópole e a CEAGESP é viabilizado pelo serviço de transporte urbano, principalmente pela ferrovia que se encontra próxima ao Entreposto.
} 
Em Ramella (1995), conseguimos uma vertente teórica que identifica a rede social como um recurso de relações da qual o migrante pode se servir para obter as informações necessárias à sua inserção no mercado de trabalho, análise esta fundamentada sob a lógica do capital.

$\mathrm{O}$ fato de encontrarmos uma comunidade de origem regional relacionada a uma mesma ocupação não é fato novo nas pesquisas, como apresenta Miguez ${ }^{14}$ (1995) em um artigo que debate alguns dos estudos realizados na Argentina. Seus estudos apresentam as redes como canais de seleção da mobilidade ocupacional, vinculados a etnias de origem. Nosso intuito é entender o comportamento da rede social em face da modernização, observar como ocorre esse mecanismo de recrutamento frente à reestruturação da produção e circulação. Encontramos denominações para tal processo, como por exemplo, Especialização Ocupacional Étnica, mas não nos preocuparemos em denominar essa forma de trabalho que envolve basicamente um dado grupo de migrantes de mesma origem, mas em perceber a mobilidade do trabalho que essa rede social enfrenta sob o capital.

Nossos estudos da rede social como suporte de inserção no mercado de trabalho, observando o seu comportamento, identifica em princípio que a rede social ocupa outras atividades, brechas no Terminal, como no caso das mulheres piauienses que se inseriram na atividade de servir cafés aos carregadores, permissionários-atacadistas ${ }^{15}$, caminhoneiros, atravessadores, e demais pessoas que freqüentam a CEAGESP.

Essas redes sociais de nordestinos nos conduziram a pensar a territorialidade dos piauienses no Terminal de Abastecimento, assim como os outros territórios que se imbricam ali, como o político, o econômico e dos negócios ilícitos. Para nos apoiar nessa reflexão, buscamos idéias de Rogério Haesbaert (2004). O autor faz uma leitura de diversos enfoques que abordam o território e o mito que cerca o conceito da desterritorialização, apontando o processo único dos múltiplos territórios ou a multiterritorialidade.

Nos caminhos percorridos ao longo da pesquisa procuramos diversificar as fontes, desde registros escritos a fontes orais, desde dados quantitativos a fontes com dados qualitativos.

O primeiromaterial que procuramos foram os periódicos que publicaram artigos ou matérias sobre a CEAGESP. Consultamos tanto jornais com maior escala de circulação, como a Folha de São Paulo e O Estado de São Paulo, como também os jornais de bairro, e publicações internas ligadas a sindicatos, à administração e mesmo as autônomas. Os

\footnotetext{
${ }^{14}$ MigUEZ (1995:31).

15 Comerciantes que têm a permissão para trabalhar na CEAGESP. Eles alugam determinadas áreas para a realização de sua atividade.
} 
periódicos locais tiveram um papel significativo no registro das relações de trabalho, de como se manifestavam e como eram concebidas pela imprensa local (Ceagente, Jornal Elo, Jornal Entreposto), assim consideramos a maneiracomo as informações foram apuradas para aqueles leitores, e buscamos uma releitura dos fatos. A leitura desses tablóides auxiliou na construção dos primeiros roteiros de caminhos que poderíamos na aplicação da entrevista.

As fontes quantitativas foram diversas; desde de dados do IBGE ou de outras instituições de pesquisa, até os próprios dados econômicos da Companhia do Entreposto. A administração da CEAGESP nos concedeu acesso às informações das fichas de cadastro dos carregadores, como sua origem por município e estado, residência por município e distrito, ou como idade, escolaridade, data de entrada no Terminal. Com esses dados em mãos, construímos algumas tabelas. Por serem estatísticos, nos possibilitaram a construção de varias representações cartográficas, como mapas e gráficos, que serviram para a análise do perfil daqueles carregadores do Terminal. Essa porta de entrada em nosso caminhar dentro da pesquisa contribuiu para visualizarmos o universo do nosso objeto de estudo e o cenário de sua inserção.

No que se refere às fontes orais, procuramos diversificar também as pessoas entrevistadas. Foram realizadas 36 entrevistas, envolvendo 28 carregadores e 8 pessoas que não trabaalham de carregadores. Neste último grupo estão os funcionários da CEAGESP, atacadistas e a médica do sindicato. Além das conversas que travamos com um grande número de pessoas que ali trabalham, compram e vivem, organizamos um roteiro de questões com temas centrais para as entrevistas. Aplicamos algumas entrevistas piloto, reelaboramos o roteiro e à medida que surgiam novas, ou as antigas indagações eram respondidas, os roteiros sofriam alterações, tendo uma dinâmica no evento da entrevista. Em nosso percurso de leituras de apoio e formação acadêmica, tivemos contato com o método de História oral, do que nos utilizamos de alguns instrumentais na escolha do momento e da forma da entrevista, assim como orienta Alberti (1990). Já em Queiroz (1988) encontramos um apoio teórico mais próximo de nosso propósito para a coleta dos relatos orais, pois o narrador seguia os assuntos propostos pelo roteiro preliminar. Depois de muitos meses de observação, escolhemos realizar as entrevistas com os carregadores no espaço do galpão do Sindicato, de preferência após o término de horário de expediente de trabalho, pois conseguíamos mais tempo disponível desses trabalhadores. As tentativas de entrevistas durante o expediente traziam um duplo problema, além da qualidade do som que ficava comprometida, às vezes não se conseguia completar o roteiro, que era interrompido por algum serviço a ser executado. O caminho da seleção dos entrevistados, seguia o das possibilidades. Mesmo assim procuramos distribuir o 
número do total de carregadores entrevistados pelos diversos setores (pescado, flores, frutas, legumes, batata), para compreendermos suas especificidades; variamos também pela faixa etária, conforme os resultados das participações, apresentados pelas tabelas que organizamos, cuja fonte foi o cadastro.

Para a compreensão de nosso objeto, estruturamos a pesquisa em quatro capítulos que, articulados, revelam o estudo da mobilidade de nordestinos na Grande São Paulo.

O primeiro capítulo, "Bandeirantes às avessas - A migração de nordestinos para a Grande São Paulo", trata da migração de nordestinos para São Paulo e das diversas políticas públicas que estimularam esse fluxo com a finalidade de ampliar a reprodução do capital. Para tal, elegemos analisar a o caráter historico dessa mobilidade, sempre sob a ótica da mobilidade do trabalho. Nos debruçamos, também, sobre uma revisão da literatura que abordou tal temática e, a partir desses estudos, pudemos um esboço da territorialidade nordestina na metrópole, e suas formas de apropriação do espaço urbano. Assim, procuramos, nesse início de investigação, entender os nordestinos em São Paulo, no espaço e no tempo, para prosseguirmos então para o nosso objeto de estudo.

O segundo capítulo, "Frutas, flores, verduras e baião de dois", aborda a Central de Abastecimento de São Paulo, o Terminal da sede da CEAGESP, como um grande mercado de trabalho, que inseriu principalmente o migrante nordestino na metrópole, entre outros migrantes. O Entreposto sempre foi estudado, em razão de sua principal função, a circulação de mercadoria, dealimento, entretanto nossa pesquisa busca um outro viés do Entreposto. Destarte, estudamos a sua importância, sua dimensão, sua dinâmica e seu funcionamento, para decifrar a diversidade de formas de trabalho que brota em seus interstícios, tanto na sua área interna, quanto, no seu entorno. Nessa parte da investigação, fomos historiar o Entreposto em São Paulo, a fim de identificar o processo de mobilidade e metamorfose desencadeado naquele espaço, importante no entendimento da presença e inserção dos nordestinos.

O terceiro capítulo, "Os carregadores do Entreposto: território dos piauienses", evoca o nosso empírico ao analisar o trabalho do carregador do Entreposto, identificando-o como uma ocupação de grupo regional ${ }^{16}$ assumida por nordestinos e, principalmente, por uma grande rede social de piauienses. A caracterização desses trabalhadores autônomos em todas as suas facetas nos levou a alguns debates sobre as suas condições e a sua organização. Algumas dessas contradições são expostas, como o conflito entre o trabalhador cadastrado e o clandestino. Outros temas surgiram à medida que a investigação prosseguia, trazendo a tona à discussão sobre o processo de modernização do abastecimento e seus reflexos nesse trabalho

\footnotetext{
${ }^{16}$ Conceito utilizado por MIGUEZ (1995).
} 
do chamado circuito inferior. Nosso foco de investigação foi estudar a mobilidade do trabalho a partir dos carregadores do terminal, entre elas a mobilidade social e as trajetórias desses migrantes.

O quarto capítulo, "Presença e rede social de Paiuienses no Terminal da Ceagesp", discute a presença da rede social de piauiense no Entreposto de Abastecimento e seus desdobramentos. A rede de piauienses materializou-se não só no espaço do trabalho como também da moradia. Identificamos essa rede social como um componente que ajuda no entendimento da mobilidade do trabalho, em que tal rede é um suporte para a força de trabalho submeter-se ao movimento da reprodução e ampliação do capital. Assim, a mobilidade do trabalho desses piauienses também envolverá temas como a migração de retorno e a migração temporária, identificadas na malha dessa rede social. Nossa pesquisa conduziu-nos a ampliar nossa análise da inserção do nordestino, ao constatar que essa inserção produz e intensifica uma territorialidade, sob o manto da modernização. O mercado de trabalho da CEAGESP é constituído por diversos territórios, além do território gerido pelo Estado ou de grupo regional, mas também, territórios geridos por economias "ilegais", apontando a fragmentação da metrópole e do migrante nesse espaço da circulação de mercadorias. 


\section{1."BANDEIRANTES ÀS AVESSAS"17 - A MIGRAÇÃO DE NORDESTINOS PARA A GRANDE SÃO PAULO}

\section{1. Uma aproximação à questão da migração nordestina: políticas públicas e a questão da seca}

O entendimento da presença maciça dos nordestinos na metrópole de São Paulo só é possível quando estudamos o processo de formação econômica do espaço brasileiro e a reprodução ampliada do capital. Tanto a compreensão das áreas de expulsão, quanto das áreas de atração fazem parte do mesmo processo. Para desvendá-lo seguimos os passos de Oliveira (1981), sob a ótica da divisão regional do trabalho e da crítica ao conceito dos "desequilíbrios regionais". A "região" é fundamentada na particularidade da reprodução do capital. Há

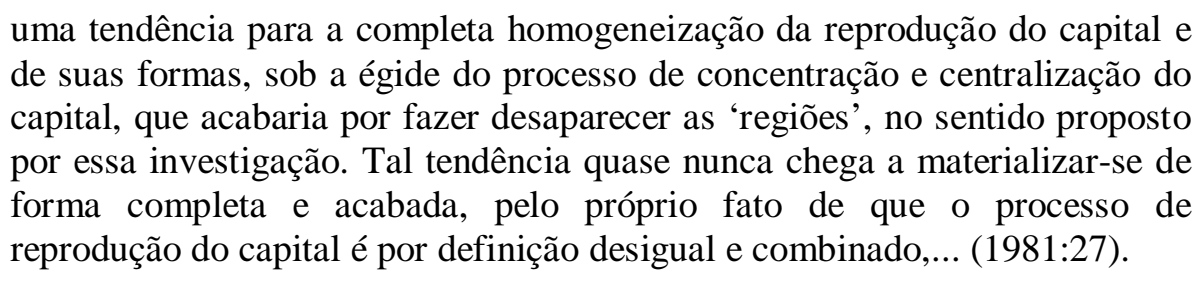

Tal reflexão teórica é a referência que o autor utiliza para explicar o desenvolvimento desigual e combinado do Nordeste e do Centro-Sul do Brasil ${ }^{18}$. Essas regiões se diferenciaram nas suas formas de desenvolvimento do capital. A partir de transformações sociais, políticas e econômicas sofridas por essas regiões, Oliveira (1981) analisa a complementaridade entre elas.

O Nordeste "açucareiro" se transformou em Nordeste "algodoeiro-pecuário" subordinado ao mercado internacional, principalmente, no século XIX. Essa economia formou uma classe latifundiária, com o controle político local, os chamados "coronéis". "Nesse rastro é que surge o Nordeste das secas" (OLIVEIRA, 1981: 35).

No Centro-Sul formou-se a oligarquia dos Barões do Café, que seguia a mesma estrutura de subordinação do Nordeste, viabilizando a reprodução do capital e atendendo aos

\footnotetext{
${ }^{17}$ Poema de Chico César recitado na Câmara dos Vereadores de São Paulo quando foi homenageado.

${ }^{18}$ Ver, também, a dicussão sobre a Divisão Territorial do Trabalho no caso brasileiro em artigo GOLDENSTEIN, L. e SEABRA, M., "Divisão Territorial do trabalho e a nova Regionalização". Revista do Departamento de Geografia. São Paulo: IGEOG/USP n.1,p.21-47,1982
} 
interesses do mercado externo. “A 'região' do café passa a ser a 'região' da indústria: São Paulo é o seu centro, o Rio de Janeiro o seu subcentro,..." (OLIVEIRA, 1981: 37).

Essas transformações ocorrem sobretudo a partir de 1930 e são resultados de uma política centralizadora, fortalecendo o Estado; tanto no Nordeste como no Centro-Sul existe uma mudança estrutural e há um enfraquecimento do poder local e das economias regionais; os chamados "arquipélagos" ligados a uma economia externa são substituídos por uma economia integrada. A concentração fundiária, e a modernização do campo somadas às mudanças nas relações de trabalho e de poder provocam uma grande expropriação e estimulam um grande fluxo migratório. Esses fluxos se intensificam nos períodos das secas. $\mathrm{O}$ crescimento demográfico se acelera, nesse período. Ao mesmo tempo, o Centro-Sul se transforma em um grande pólo de atração, pela dinâmica de sua economia.

A conversão da região do café em 'região` da indústria começa a redefinir a própria divisão regional do trabalho em todo o conjunto nacional. Seu papel nessa divisão regional do trabalho no que respeita à região Nordeste passa a ser de um lado, sistematicamente, a reserva do exército industrial de reserva: as migrações Nordeste - São Paulo chegam a constituir um formidável contingente que vai suprir os postos de trabalho criados pela industrialização, e contribuir para manter baixos os níveis de salário real de toda a massa trabalhadora..." (OLIVEIRA, 1981: 37).

Singer (1973) reforçou a teoria de que as desigualdades regionais são o motor das migrações internas, as quais acompanham a industrialização das regiões mais desenvolvidas. A divisão regional do trabalho aponta para a interdependência dessas regiões. Há uma subordinação econômica em que algumas regiões do país que exportam matéria-prima e mãode-obra, denominada naquele contexto de exército de reserva, e importam produtos industrializados de outra região. Singer faz uma leitura da urbanização brasileira, principalmente de São Paulo:

A mobilização deste exército de reserva se fez paulatinamente, entre 1930 e 1945, a partir da abolição da autonomia dos estados, que serviu tanto para unificar o mercado interno como derrubar oligarquias locais, cujo poder sobre a população rural foi consideravelmente enfraquecido. A construção de uma rede de rodovias, que passou a interligar as principais regiões do país, facilitou as comunicações e estimulou enormemente as migrações internas. (SINGER, 1973:122).

A cidade de São Paulo, desde o início do século XX, concentrou um grande número de indústrias. $\mathrm{O}$ ciclo do café trouxe à cidade alguns elementos, como a ferrovia, bancos, mãode-obra, mercado regional, entre outros, que serviram de apoio para as primeiras indústrias nacionais. Explica o autor: 
O fator isoladamente mais importante que privilegiou São Paulo como zona industrial é a sua situação geográfica, que lhe assegurou acesso a uma área, onde se encontrava a maior parte do mercado interno brasileiro. Fatores puramente geográficos, estudados sobretudo por Caio Prado Jr., [...], tornam tributária de São Paulo uma ampla área do país, que ultrapassa as fronteiras do atual Estado de São Paulo. Os laços que ligam esta área à cidade de São Paulo foram reforçados pelo sistema ferroviário, construído para atender ao escoamento do café, o sistema São Paulo - Santos. (SINGER,1974: 51).

Não há dúvida que a integração do espaço nacional, por meio de ferrovias e rodovias, acelerou e estimulou a migração inter-regional, aumentando deliberadamente o número de nordestinos em São Paulo. Outros elementos contribuíram para a expansão dessa migração, como a política trabalhista de Getúlio Vargas que regulamentava algumas reivindicações do operariado, entre elas o salário mínimo. Os salários nas áreas urbanas eram um atrativo à migração inter-regional, pois os ganhos salariais, apesar da legislação federal, eram e são diferenciados.

Outro fator significativo é a política migratória, em 1930, para a qual Getúlio Vargas, na gestão do Ministro do Trabalho Lindolfo Collor, propõe uma lei de cotas (Decreto n.19482 de 12/12/1930), que desestimula a imigração externa. Ele assina um decreto que limita “... em 1/3 o número de trabalhadores estrangeiros por empresa, é dado um passo decisivo para que os trabalhadores nacionais superem em número os estrangeiros na composição da classe operária”.(ALBUQUERQUE Jr., 1990: 28). A partir da publicação do decreto, havia o prazo de 90 dias para a verificação dessa cota de brasileiros natos em todas as categorias profissionais. A reserva de mercado para o trabalhador nacional se viabilizaria a partir da limitação da entrada no país de passageiros de $3^{\mathrm{a}}$ classe da lei de cotas. ${ }^{19}$ Essa lei tinha um efeito desmobilizador para o movimento operário. A política de nacionalização da mão-deobra foi reafirmada no Decreto 19.770 de 19/03/1931, em que exigia a proporcionalidade de 2/3 de nacionais para os cargos de direção na estrutura sindical. Houve uma simultaneidade entre a política de nacionalização da mão de obra e a migração de nordestinos para São Paulo. Vejamos a seguinte afirmação:

Esta releitura do movimento imigratório e da função social das migrações internas tinha um conteúdo político esclarecedor. Os nordestinos que desde meados da década de 1920 haviam começado a se deslocar para São Paulo e Rio, assumiam a personalidade de novos bandeirantes que 'retomariam' a terra para os nacionais. Tal deslocamento não possuía, portanto, um conteúdo negativo, na medida em que o Nordeste - vestindo-se de brasilidade - nacionalizaria o Sul, esmagado pelo internacionalismo...(GOMES, 1982:161).

\footnotetext{
${ }^{19}$ Nos estudos de MONBEIG (1998:155) ele faz referência a lei de cotas , que foi inspirada na legislação norteamericana.
} 
Paiva (2004) destaca o processo de modernização sem mudanças, em que o projeto de integração nacional pautava um novo padrão de acumulação do capital; nesse cenário estimula-se a migração de nordestinos para São Paulo, o que significa a materialização e visibilidade desse processo de modernização. A construção negativa de uma representação do Nordeste como lugar de atraso, em que a imagem de região seca, pobre e inviável é reforçada, colocava se diante da visão que se tinha de que São Paulo representava o lugar das possibilidades de uma vida melhor. Tais representações acabam promovendo a migração e escamoteando as relações econômicas presentes nessa totalidade.

Outro aspecto desse processo é evidenciado no documento elaborado pelo governo em um projeto apresentado à República Federal Alemã (SUDENE-BOLETIM ECONÔMICO, vol. 1, 1962): "a crescente pressão demográfica que se destaca no Nordeste tem suscitado problemas sociais e políticos de suma gravidade..." (OLIVEIRA,1981:114). O texto segue citando o aparecimento de associações camponesas, ou seja, havia uma pressão social para a distribuição de terras, que se não fosse "resolvida" poderia estourar em grandes movimentos sociais, reivindicando a Reforma Agrária. A válvula de escape que o governo encontrou foi estimular a migração para o Centro-Sul, desarticulando os movimentos sociais. Assim "as migrações internas apareciam antes como solução do que como problema"(VAINER, 2000: 25).

O problema da seca sempre elevou o número de migrantes nordestinos para o CentroSul. Muitas vezes, a questão era falsamente tratada como uma catástrofe natural que ocasionava esses deslocamentos forçados. Todavia, identificamos a "questão da seca" como um problema social, a qual denominou-se de indústria da seca, em que a estrutura agrária fez com que o camponês nordestino participasse dessa "grande diáspora".

Desde o período colonial, tanto no nordeste açucareiro como no sertão algodoeiro e pecuário, a sociedade nordestina era controlada politicamente e economicamente pelos senhores de engenho e coronéis do sertão.

Cada latifúndio constituía uma realidade social à parte, muitas vezes superior à ordem pública. Coronéis e senhores de engenho dominavam, sem concorrentes, as câmaras municipais e as representações políticas tanto a nível estadual quanto a nível federal. Por isso, cada coronel ou senhor do engenho possuía em torno de si pequenos exércitos de cangaceiros (sic) formados pela parentela numerosa, pelos agregados e moradores. Aos que não pertenciam a esta instituição restavam apenas o silêncio e a resignação. (SOUZA e MEDEIROS F ${ }^{\circ}$, 1983: 26).

Nesse momento da história, as manifestações da população, encontradas diante do quadro apresentado, ou era pelo cangaço ou pelo messianismo. Esse poder das oligarquias 
regionais só perde suas forças diante do centralismo, nos anos 30, com o "Getulismo". Todavia, os mesmos grupos continuam a dominar, mas agora usando outros instrumentos: as burocracias oficiais. Mesmo com as mudanças sociais e políticas desde a colonização, a estrutura fundiária continua concentrada nas mãos de poucos proprietários.

Nos períodos de seca, as primeiras vítimas são os pequenos proprietários ou os "deserdados da terra". A agricultura de subsistência não resiste aos longos períodos de seca e o trabalhador rural se vê obrigado a migrar para a sua manutenção e, muitas vezes, a de sua propriedade. Os grandes proprietários quando eram atingidos pela seca, ora recebiam créditos em longo prazo e juros muito baixos, ora tinham o apoio do Estado, via SUDENE (Superintendência e Desenvolvimento do Nordeste) e DNOCS (Departamento Nacional de Obras Contra a Seca). Os recursos destinados para o combate à seca eram desviados e absorvidos pelos latifundiários, alguns dos quais ocupavam e ainda ocupam cargos nos órgãos do Estado. "O meio rural, sobretudo as pequenas propriedades, se transformam num verdadeiro campo de fuga" (SOUZA e MEDEIROS Fº 1983: 51).

Souza e Medeiros $F^{\mathbf{o}}$ (1983) historiam as secas no Nordeste, desde os primeiros registros no século XVI, relatando a fuga dos indígenas do sertão para o litoral, contada pelos jesuítas, até o século XX. Sua pesquisa registra o flagelo ocasionado pelas secas, em que a fome, a miséria, a morte do gado e o grande número de óbitos são as figuras constantes dessa saga. Cena constante nos períodos de seca é o consumo de água enlameada pelos flagelados que cavam as cacimbas no leito dos açudes. Com a falta de chuva e os poços vazios, as pessoas recorrem a todo tipo de estratégia de sobrevivência, como se alimentar de calango, maniçoba, aproveitar a água reservada pelo Xiquexique ou Macambira, buscar água a muitos quilômetros de distância; e numa atitude desesperada, saquear o comércio das cidades. E, por fim, a alternativa é partir, mobilizados para outras áreas, fugindo desse flagelo. ${ }^{20}$

Azevedo (2002) estudou a experiência dos migrantes nordestinos em relação a sua memória, e uma das fontes foram os romances, a música popular e a representação pictórica que monumentalizam a experiência migratória, o que a autora denomina de patrimônio figurativo do tema.

\footnotetext{
20 Essa situação foi bastante representada por poetas, escritores, artistas plásticos, músicos, repentistas e fotógrafos, segue alguns exemplos - Na literatura: Morte e vida Severina (João Cabral de Melo Neto), O Quinze (Raquel de Queiroz), Menino do Engenho (José Lins do Rego), Vidas Secas (Graciliano Ramos). Nas artes plásticas: Os Retirantes(Cândido Portinari), Segunda Classe (Tarsila do Amaral), na música: Asa Branca, Vozes da Seca, A volta da Asa Branca, Pau-de- Arara (Luiz Gonzaga/Zé Dantas); no cordel: Triste Partida (Patativa do Assaré,1957), Paulista Virou Tatu Viajando pelo Metrô (Rodolfo Coelho Cavalvante), A Migração do Nordeste a São Paulo, O que faz o Nordestino em São Paulo (João de Barros).
} 
Em 1959, foi criada a SUDENE (Superintendência para o Desenvolvimento do Nordeste), que criou as chamadas "frentes de trabalho", proporcionando empregos nas barragens e estradas. Porém, todas essas medidas foram emergenciais e insuficientes. As histórias, tanto da SUDENE, quanto do DNOCS, foram acompanhadas de corrupção e desvio de recursos. Estes órgãos foram extintos em 2002, no governo de Fernando Henrique Cardoso e ressuscitados na gestão de Luís Inácio Lula da Silva.

A "indústria da seca" é a denominação dada a todo esse processo, em que há a apropriação indevida dos recursos financeiros públicos enviados para socorrer os flagelados, ou o tráfego de influência em benefício dos detentores do poder, ou ainda a montagem de um sistema de exploração em cima de uma população exaurida nos seus pequenos e inexistentes recursos. ${ }^{21}$ Era prática comum montar, próximo as frentes de trabalho, os "barracões" que vendiam, a preços exorbitantes gêneros alimentícios, tornando os trabalhadores escravos por endividamento; ainda, formavam-se esquemas de agenciamento de mão-de-obra, com o objetivo de extorquir dinheiro; outra forma de enriquecer com a seca era a partir das obras superfaturadas, que muitas vezes nem existiam. Dessa maneira, a seca gerava "lucro" para determinados grupos, daí a denominação "indústria da seca".

Vejamos o quadro, organizado por Souza e Medeiros (1983) que mostra a dimensão das secas em diversos períodos:

21 Souza \& Medeiros (1983). 
Tab. 1: Quadro das secas ocorridas no Nordeste

\begin{tabular}{|c|c|c|c|}
\hline \multicolumn{2}{|c|}{ ANOS SECOS } & \multirow{2}{*}{$\begin{array}{c}\text { DURAÇÃO DAS SECAS (em anos) } \\
01\end{array}$} & \multirow[t]{2}{*}{ TOTAL DAS SECAS } \\
\hline Século XVI & 1559 & & \\
\hline & 1587 & 01 & \multirow{3}{*}{04} \\
\hline & 1564 & 01 & \\
\hline & 1592 & 01 & \\
\hline \multirow[t]{6}{*}{ Século XVII } & 1603 & 01 & \multirow{6}{*}{06} \\
\hline & 1609 & 01 & \\
\hline & 1614 & 01 & \\
\hline & 1645 & 01 & \\
\hline & 1652 & 01 & \\
\hline & 1692 & 01 & \\
\hline \multirow[t]{7}{*}{ Século XVIII } & $1710-1711$ & 02 & \multirow{7}{*}{07} \\
\hline & 1722 & 01 & \\
\hline & $1723-1728$ & 06 & \\
\hline & $1744-1746$ & 03 & \\
\hline & 1766 & 01 & \\
\hline & $1777-1778$ & 02 & \\
\hline & $1790-1793$ & 04 & \\
\hline \multirow[t]{12}{*}{ Século XIX } & 1803-1804 & 02 & \multirow{12}{*}{12} \\
\hline & $1808-1810$ & 03 & \\
\hline & 1814 & 01 & \\
\hline & 1817 & 01 & \\
\hline & $1824-1825$ & 02 & \\
\hline & 1833 & 01 & \\
\hline & $1844-1846$ & 03 & \\
\hline & 1860 & 01 & \\
\hline & 1869 & 01 & \\
\hline & $1877-1879$ & 03 & \\
\hline & 1888-1889 & 02 & \\
\hline & 1898 & 01 & \\
\hline \multirow[t]{12}{*}{ Século XX } & 1900 & 01 & \multirow{12}{*}{12} \\
\hline & 1903-1904 & 02 & \\
\hline & 1915 & 01 & \\
\hline & 1919 & 01 & \\
\hline & 1931-1932 & 02 & \\
\hline & 1942 & 01 & \\
\hline & $1951-1953$ & 03 & \\
\hline & 1958 & 01 & \\
\hline & 1966 & 01 & \\
\hline & 1970 & 01 & \\
\hline & 1976 & 01 & \\
\hline & 1979-1982 & 04 & \\
\hline \multicolumn{2}{|c|}{ Total Geral } & & 41 \\
\hline
\end{tabular}

Fonte: Souza \& Medeiros $\mathrm{F}^{o}$. Os degredados filhos da seca, 1983:.38. 
A seca de 1970 atingiu cerca de 500 mil pessoas, diretamente, alcançando outros dois milhões, posteriormente; afetou oito estados, 605 municípios, o que corresponde a 570 mil $\mathrm{Km}^{2}$. Foi, portanto, uma das mais violentas do século XX.

A seca que se iniciou em 1979 e termina, segundo o Centro Técnico Aeroespacial, em 1985, atingiu todos os estados nordestinos, afetando 9 milhões de pessoas, nos mais de mil municípios castigados.

Para se referir aos migrantes nordestinos, encontramos na literatura uma diversidade de denominações como, "retirantes", "flagelados da seca", "vítimas das secas"; havia uma leitura do processo migratório, baseada na teoria positivista, que via a migração de nordestinos para o Centro-Sul como fato ocasionado estritamente pelo fenômeno natural da seca. Essa naturalização do processo, em que se reforça o uso das expressões acima, acaba remetendo a migração ao problema da seca; desorientando a discussão central que é a da mobilidade do trabalho.

\section{2. O processo de mobilização dos nordestinos para São Paulo}

A teoria da mobilidade do trabalho, formulada por Gaudemar (1977), cujo enfoque está na produção e na circulação da força de trabalho, ajuda-nos a compreender melhor a migração de nordestinos para São Paulo. O deslocamento espacial dos nordestinos para São Paulo contribuiu, assim como os imigrantes externos, de forma decisiva para viabilizar o processo de produção capitalista. Parte dessa força de trabalho é formada pelos nordestinos que vêm para São Paulo integrar o denominado exército industrial de reserva, que é um excedente de mão de obra, mantendo os salários baixos. Gaudemar elabora sua teoria a partir das análises de Marx sobre a reprodução do capital. Denomina-se mobilidade do trabalho na medida em que há um uso capitalista dos corpos dos trabalhadores. Esse uso determina, também, deslocamentos espaciais, bem como, o uso dos corpos em diferentes condições de intensidade e ritmos de produção com o propósito de extrair a máxima produção de valor.

O capital mobiliza um exército de homens para a sua reprodução, o que explica os deslocamentos populacionais, os grandes fluxos de pessoas que buscam "melhores condições de vida". As condições políticas, econômicas e sociais vigentes no Nordeste, ao longo do século XX, "excluem" grande parcela dessa população dos elementos vitais de sua sobrevivência. Constatamos que essa migração é uma mobilidade forçada, uma estratégia que o capital usa para a sua reprodução. O capital acaba designando a esse grupo as áreas de destino, ou os chamados pólos de atração, que no caso é São Paulo. Nesse período de 
flexibilização das relações de trabalhado encontramos uma parte dos migrantes nordestinos em mobilidade contínua. Devemos considerar que a teoria de Gaudemar foi elaborada, na fase do fordismo, em que as questões sobre trabalho eram outras.

Para compreender, portanto, a mobilidade do trabalho, sentimos necessidade de recuperar o processo histórico da migração nordestina para São Paulo. Para isso, recorremos a uma revisão da literatura historiográfica, que reconstrói o processo e aponta para novas questões sobre a vinda dos nordestinos para São Paulo.

Em estudos anteriores, encontramos registros cuja fonte básica era a Hospedaria do Imigrante e que datavam a chegada dos primeiros migrantes nordestinos na cidade e no estado de São Paulo, em 1901. Assim registra Bosco e Jordão Neto (1967: 10): "Estado recebeu nesse ano [1901], 1434 migrantes internos frente aos 70.348 migrantes estrangeiros".

Entretanto, recentes pesquisas mostram uma outra versão dos fatos como encontramos em Gonçalves (2002) e Paiva (2003), autores em quem nos embasamos para esse resgate histórico. O primeiro autor estudou as migrações nordestinas, no final do século XIX, para o Centro-Sul do país, onde se procurava superar o modelo escravista. Contratava-se essa força de trabalho nordestina para as lavouras cafeeiras, que estavam em plena expansão.

Diferente da maioria da literatura que trata da mão-de-obra livre para o café, associada a imigrantes estrangeiros, o autor registra um contingente "significativo" de nordestinos neste setor especialmente cearenses, atingidos pela seca de 1877. A pesquisa mostra a existência de uma política de mobilização de nordestinos para as lavouras de café, desde o Império até o início da República. Eles eram requisitados pelos fazendeiros para a formação, trato e colheita do café. Entretanto, a divisão do trabalho também é registrada, pois os migrantes nordestinos, junto com os caboclos, eram contratados por empreitada; realizavam o serviço de derrubada da mata para a abertura de novas áreas de lavoura cafeeira, enquanto aos europeus eram designadas as tarefas menos rústicas. ${ }^{22} \mathrm{O}$ Governo Federal financiava o deslocamento desses contingentes, custeando as passagens e, assim, eles se transformavam em "força de trabalho disponível para a lavoura", não somente para as fazendas do Centro-Sul, mas também para os engenhos de Pernambuco e para as plantações de cacau da Bahia. Esse processo ocorreu de forma diferenciada nos espaços do Centro-Sul. O trabalhador nacional dentre eles, inclusive nordestinos, foi a principal mão-de-obra no Vale do Paraíba e na Zona da Mata Mineira, enquanto que no Oeste Paulista, predomina a mão-de-obra estrangeira.

\footnotetext{
22 ESTRELA (2003:45-46) encontrou referências sobre baianos que foram arregimentados por emissários de fazendeiros paulistas, em 1850, tanto na obra de João Gumes, como também, na obra de Walter Fraga Filho.
} 
No caso do aproveitamento dos retirantes cearenses, surgiu, simplesmente, a oportunidade de se conseguir aumentar a oferta de trabalhadores na tentativa de baixar ainda mais os custos de produção. Os grandes proprietários, contando com o apoio do poder central, não hesitaram em aproveitar os migrantes como mão-de-obra para seus cafezais. (GONÇALVES, 2002:169).

Vejamos dois momentos de ações dessa política migratória. O primeiro em 1888 e 1889, o presidente da província do Ceará, o paulista Caio da Silva Prado, de família tradicional ligada à economia cafeeira, estimulava a ida dos "flagelados" para São Paulo e o segundo, em 1900, o Governo Federal, tendo Campos Salles como presidente da República, por ocasião das secas, financiou passagens às vitimas para São Paulo.

Mesmo estigmatizados pela elite paulista em relação à sua capacidade de adaptação ao trabalho regular, os migrantes nacionais participaram juntamente com o imigrante europeu, na conformação do trabalho-livre, abaixando os custos da reprodução da cafeicultura. A política de estímulo à migração interna não era consensual, pois alguns políticos se referem, em seus discursos, ao temor do despovoamento ou esvaziamento das áreas de expulsão. Gonçalves (2002) recupera as discussões acaloradas do parlamento, os jornais, os congressos agrícolas e os relatórios oficiais em que os preconceitos e a desconfiança aparecem nos discursos: "Os que eram contra afirmavam que a preguiça e o ócio faziam parte da índole dessa população pobre. Os que defendiam creditavam tais características a suas precárias condições de vida."

(GONÇALVES, 2002: 170).Vejamos um discurso na sessão da Câmara dos Deputados, em 1879:

Tem-se querido concluir que o imigrado do norte é um homem incapaz do trabalho, naturalmente desidioso, não senhores, o caso é diverso. [...] A Verdade é esta: não se espere no entanto que a maioria dos cearenses emigrados preste à lavoura grandes serviços. Os que não eram pastores, eram lavradores, porém livres, ou proprietários. A subdivisão do solo no Norte do Império é completa; todos que querem podem ter sua casa, quase todos possuem seu palmo de terra. Estes homens podem sujeitar-se ao trabalho das fazendas do Rio de Janeiro, Minas e São Paulo? Podem facilmente tomar a enxada ao lado do escravo que lhes desconhecem como seus iguaes para o trabalho agrícola, e têm em certa aversão? Elles não comem de ração, são jornaleiros algumas vezes, mas tendo a sua vivenda, livre da autoridade senhorio. (Anais da Câmara dos Deputados in: GONÇALVES,2002: 152).

Outro registro encontrado no Boletim do Departamento Estadual do Trabalho, em 1920:

O Cearense precisa de ser acclimatado e de aprender a maneira de trabalhar nas lavouras de café paulistas, como qualquer outro immigrante. Reconhecemos mesmo que elle tem duas inferioridades sobre os immigrantes estrangeiros: 
1. ${ }^{a}$ Elles no chegam num estado de miseria organica deploravel, o que se dá pelo effeito da penunria a que são reduzidos quando, devido ás seccas, são tocados para fora de seu Estado.

2. ${ }^{a}$ Habituados a uma vida sem aspirações e a uma icerteza absoluta do dia de amanhã, quando chegam a São Paulo, mostram na sua maior parte, pouca ambição e daí uma natural indolência (sic). (LEME apud GONÇALVES, 2002: 165$)^{23}$.

Para a elite paulista, o trabalhador nacional era desqualificado, exigia-se "disciplina, eficiência, sobriedade e morigerado". E, então, essa mesma elite para lidar com o trabalhador "insubordinado e rebelde", criou leis coercitivas e instrumentos de repressão. Era o momento em que as relações de trabalho estavam se transformando, do trabalho escravo para o colonato. Os fazendeiros estavam começando a se relacionar com o trabalho livre, pois só conheciam o trabalho escravo. E o nordestino chega nesse contexto, em que muitas vezes foi tratado como "escravo"; ora regiam as condições contratuais e ora regiam as condições coercitivas.

Cabe lembrar que nesse período ocorreu um grande fluxo de nordestinos para trabalhar na extração da borracha, principalmente, na região amazônica. $\mathrm{O}$ custo da passagem para o Centro-Sul era superior ao custo para a Amazônia. Com o subsídio do Governo Imperial criam-se condições para que os fazendeiros de café pudessem competir com a economia da borracha, redirecionando o fluxo dessas migrações.

Os migrantes vinham em vapores denominados de "Navios Negreiros". Conforme afirma Souza e Medeiros Fo (1983:59) sobre a migração de 1904: “Aqueles grupos de camponeses que não queriam emigrar, o governo os obrigava através do seu aparelho policial. Houve casos de embarques realizados à força em que o marido foi para o Norte e a mulher para o Sul."

Era comum o desmembramento familiar no embarque caótico como bem ilustra o texto acima. Essas viagens tendiam a ser dramáticas, pois muitos embarcavam doentes ou adoeciam no trajeto e chegavam sem vida no seu destino.

Os nordestinos que vinham pelos vapores ainda no Brasil Império desembarcavam na capital, sobretudo, Rio de Janeiro e ficavam alojados na Hospedaria da Ilha das Flores, e de lá eram encaminhados para São Paulo, Espírito Santo, Rio de Janeiro e Minas Gerais. Esses podiam desembarcar também nos portos paulista e capixaba. No Rio de Janeiro, trabalharam

\footnotetext{
${ }^{23}$ André Betim Paes Leme. "Contribuição para o estudo da adaptação dos cearenses como colonos nas lavouras de São Paulo”. Boletim do Departamento Estadual do Trabalho. São Paulo: Typographia Brasil de Rottschild \& Cia, Ano IX, ns.34 e 35, 1920. pp.137-141.
} 
na lavoura canavieira e na construção da Estrada de Ferro Leopoldina; no Espírito Santo, eles trabalhavam na lavoura de café e na farinha de mandioca.

Depois da longa viagem a vapor, tanto aqueles que desembarcavam na capital do Império quanto àqueles que chegavam pelo porto de Santos, seguiam viagem pelas ferrovias para a hospedaria paulista. Porém, segundo registros, nem todos paravam na hospedaria, muitos seguiam direto para o interior paulista, para as fazendas.

Observamos que a maioria destes nordestinos que migraram para São Paulo eram oriundos do Ceará, mas houve também grupos menores de potiguás, que foram tratados como cearenses. A tabela "Entrada de Imigrantes e Nacionais em São Paulo entre 1870 e 1901" (anexo 1), organizada por GONÇALVES (2002), mostra como os números oficiais de entrada de nacionais indicam a pouca importância desse grupo de migrantes, resultando na subestimação da temática. ${ }^{24}$ Seus estudos avaliam que vieram com subsídio do Estado, 1.300 cearenses, aproximadamente, para São Paulo. É pertinente mencionar que 4.293 migrantes foram registrados entre janeiro e setembro de 1878, no porto do Rio de Janeiro, pela Inspetoria Geral de Terras e Colonização. O relatório do Presidente da Província de São Paulo registra uma dezena de migrantes cearenses que se hospedaram no Alojamento do Bom Retiro, entre 1881 e 1886.

A força de trabalho nordestina era, na verdade, apenas uma reserva de mão-de-obra, para os momentos de sua crise e esse situações eventuais, como foi usada circunstancialmente, como ocorre durante a Primeira Guerra Mundial (1914-1918), em que há falta de braços europeus para suprir as necessidades dos cafezais.

No entanto essa situação não se configura uma política sistemática, de acordo com GONÇALVES (2002), porém ela reordena os nossos estudos anteriores que indicavam os subsídios estatais aos nordestinos apenas após o grande fluxo de migrantes europeus e asiáticos. Após esta fase foi que a política de migração interna passou a ser mais organizada, viabilizou a transferência de milhões de nordestinos para o Centro -Sul.

Durante a política de "branqueamento" da população que se instaura, a migração estrangeira foi intensamente estimulada. Entraram 2.901.204 imigrantes, segundo as estimativas oficiais sobre o número de europeus e asiáticos que migraram para São Paulo entre 1887 e 1936. A eugenia, ou melhor, a idéia do "êxodo civilizador" era o discurso de

\footnotetext{
${ }^{24}$ A pesquisa de GONÇALVES (2002), além de consultar a Hospedaria do Migrante em São Paulo, recorre a outras fontes como a Companhia de Vapores e o Arquivo do Estado de São Paulo, diferente de JORDÃO NETO que usa somente a Hospedaria como sua única fonte.
} 
alguns intelectuais ${ }^{25}$, apropriado pelos fazendeiros de café do Oeste Paulista; reforçava-se o preconceito para com a mão-de-obra nacional ${ }^{26}$. Vejamos os dados que Martin (1984:63). apresenta:

Entre 1887 e 1930 deveriam entrar na Província de São Paulo, nada menos que 2 milhões e 500 mil imigrantes, incluindo-se aqui cerca de $280 \mathrm{mil}$ nacionais de outras províncias e 85 mil japoneses. A maioria deles contudo era composta por italianos. De 1887 a 1915 entraram na província cerca de 800 mil italianos, vindo a seguir em importância os espanhóis com 300 mil e os portugueses com 260 mil.

Essa política de branqueamento, vinha no sentido de combater a "onda negra"; com a chegada de ex-escravos oriundos do Nordeste, acentuava-se o temor coletivo na província de São Paulo, em relação à possibilidade de abalar a ordem estabelecida pela elite paulista branca. Pairava o fantasma da Revolução no Haiti e a Guerra da Secessão Americana, em que os negros conseguiram alguns direitos, além, de uma resistência no Brasil ao cativeiro. Nesse contexto, aparece o discurso imigrantista, que, ao pregar a purificação da raça, busca um projeto de identidade nacional. Assim, os nordestinos são aqueles que têm no sangue a "inferioridade racial", pois são caracterizadas pela indisciplina, vadiagem, ociosidade, preguiça, indolência e inaptidão. Havia uma série de adjetivos que desqualificavam o migrante nordestino, responsabilizando-o pelo atraso econômico do país, enquanto que o europeu representava o progresso e o avanço civilizatório. Na verdade, essa representação velava a não sujeição do migrante interno ao tempo, exigido pela reprodução do capital, pelos capitalistas fazendeiros de café; exigência que se confrontava com seu modo de vida e valores culturais, assim como a promoção da importação de braços em enormes quantidades criava condições de deteriorar os salários e desarticular qualquer possibilidade de resistência. ${ }^{27}$

A política do "branqueamento" permaneceu hegemônica até a Primeira Guerra Mundial, pois nesse momento, com a falta de mão-de-obra estrangeira, valoriza-se a nacional. Os migrantes estrangeiros, que antes representavam o progresso, passaram a ser considerados uma ameaça ao Estado, pois traziam consigo novas concepções de organização social, entre elas o socialismo e o anarquismo. A elite paulista se vê ameaçada e volta suas preocupações com relação à identidade nacional. O Estado deixa de promover a migração externa, passando a estimular a interna. Em 1927-1928 terminam os subsídios governamentais para a entrada de imigrantes estrangeiros, encerrando definitivamente essa política. Encontramos em Vainer

\footnotetext{
25 Arthur de Gobineau, José Ingenieros, Louis de County e Louis Agassiz (SKIDMORE apud GONÇALVES,2002:52).

${ }^{26}$ A mão de obra nacional envolve, não apenas os nordestinos, como também migrantes de outros estados como mineiros e os próprios paulistas.

${ }^{27}$ Ibid., p. 63
} 
(2000) alguns elementos que reorientam essas mudanças. A concepção de Kystos Éthnicos que ameaça a nacionalidade e a integridade territorial do país se faz presente, havendo a preocupação com o grande contingente de migrantes externos:

O imigrante, cujo amor ao trabalho, disciplina e eugenia haviam sido exaltados como salvação da pátria, aparecia, agora, à luz da problemática assimilacionista, como grande ameaça a esta mesma pátria. Desconhecedor de nossos costumes, fiel a outros Estados, o imigrante era ainda mais perigoso quando adepto do anarquismo ou socialismo, ideologias dissolventes completamente estranhas à índole pacífica e cordata de nosso povo. (2000:19).

A partir dos anos 30, principalmente na Segunda Guerra Mundial (1939-1945), deixase de promover esse fluxo. Enquanto isso havia uma crise agrária, ou melhor, uma pressão exercida por um grande contingente populacional, cada vez maior, sobre a estrutura fundiária. O estímulo à migração interna aparece, assim, como uma forma de controle social e político.

Nos corredores da Hospedaria do Imigrante, em São Paulo não se ouvem mais o italiano e o espanhol, agora substituídos pelos sotaques nordestino e mineiro... afinal de contas, São Paulo, que não pode parar, já havia descoberto desde os anos 40 que os nordestinos e mineiros, os trabalhadores nacionais podem ser disciplinados para o trabalho... (VAINER, 2000: 24).

Os migrantes nordestinos, incentivados pelo Estado, eram alojados na mesma estrutura usada para a recepção da imigração estrangeira, a Hospedaria do Imigrante. ${ }^{28}$ Situada nas proximidades da antiga Estação do Norte, atual Estação Roosevelt, possuía plataforma própria, o que auxiliava a recepção dos migrantes, tanto estrangeiros como os nacionais. $\mathrm{O}$ fato de estar localizada próxima da confluência entre importantes estradas de ferro, como a Estrada de Ferro Santos-Jundiaí ${ }^{29}$ (1867), e a Estrada de Ferro Central do Brasil (1877), que liga São Paulo ao Rio de Janeiro, permitiu a recepção dos migrantes da região norte de Minas Gerais e Nordeste e também daqueles que chegavam ao estado por via marítima, a partir do porto de Santos. Essa malha ferroviária, criada para facilitar o escoamento do café, serviu como apoio na distribuição dos migrantes em São Paulo, pois esses seguiam suas viagens pelas Companhias Sorocabana, Mogiana, Paulista, Noroeste e Araraquarense para a necessidade de suprir a mão-de-obra nas lavouras paulistas, conforme já discutido.

\footnotetext{
${ }^{28}$ Construída na gestão de Antonio de Queiroz Telles, como Presidente da Província e inaugurada em 1887, no bairro do Brás (ANDRADE, 1994).

${ }^{29}$ Denominada antigamente de São Paulo Railway -SPR.
} 
A Hospedaria de Imigrantes, com a capacidade de alojar cerca de 4 mil pessoas ${ }^{30}$, possuía uma Agência Oficial de Colocação, que passou, a partir da década de 1930, a receber, classificar e atender aos pedidos de mão-de-obra dos fazendeiros paulistas. Além da Agência, havia os dormitórios, refeitório, um depósito de bagagens, um pequeno hospital, enfermaria e um setor de recepção, triagem e encaminhamento dos trabalhadores que chegavam. $\mathrm{Na}$ Hospedaria, os nordestinos pernoitavam um ou dois dias e eram submetidos a uma triagem que consistia em verificar seus documentos, suas condições de saúde e o local de destino. $\mathrm{O}$ serviço médico na hospedaria tinha um papel significativo na triagem, encaminhamento, e até determinando o retorno ao local de origem, para os migrantes que eram considerados inaptos para o trabalho.

Atendendo às necessidades dos cafeicultores, o Estado criou em 1939, o Departamento de Imigração e Colonização, vinculado à Secretaria de Agricultura, Indústria e Comércio. O objetivo era conduzir os imigrantes nacionais às fazendas de café; estima-se que no ano de 1939 ingressou no Estado paulista 100 mil nordestinos e mineiros. ${ }^{31}$ Há uma queda deste fluxo na década de 40, em virtude de um novo ciclo extrativo da borracha na Amazônia. Essa diminuição continua em 1950, pois tanto a economia cafeeira declinou quanto as necessidades econômicas de São Paulo se transformaram. Segundo Jordão Neto, em entrevista realizada, em 1995, pelo grupo de estudos migratórios do Labur (USP)/CEM:

Iniciamos o trabalho no Departamento e ainda havia algum movimento de
imigrantes. A partir de 1960 foi arrefecendo, e hoje, a migração decaiu.
Quase todas as correntes migratórias passavam pelo Departamento de
Migração e Colonização. O pessoal vinha, desembarcava de trem na
estação Roosevelt, estação do Norte, e os imigrantes que vinham de Santos
já desciam diretamente no Departamento, pois ali havia uma estação. Até
aquele momento tinha um significado, o Departamento de Imigração e
Colonização ocupava um papel relevante, pois era um termômetro da
própria economia. Media o circuito, os círculos migratórios, registrava o
movimento e sabíamos quando significava uma situação de crise lá no
Nordeste com a diminuição da população; mas também podia estar
significando um fator de atração momentânea, relacionada ao círculo
vegetativo das culturas do estado de São Paulo. Sempre no início do ano o
afluxo era grande por causa das colheitas, mês de julho caía bastante,
depois, a partir de setembro loutubro, começava a crescer outra vez. (Jordão
Neto-18/08/95).

Jordão Neto destaca o grande fluxo no “alvorecer dos anos 30" pois a expansão dos cafezais e da cultura do algodão estava absorvendo mais mão-de-obra. Nesse relato, o

\footnotetext{
${ }^{30}$ Segundo Reale (1982) a Hospedaria passa a abrigar 2000 pessoas. No Catálogo publicado pelo Memorial do Imigrante (1997) afirma que sua capacidade é para receber 3.000 pessoas. "em ocasiões especiais chegou a abrigar até 8.000 de uma só vez" (p. 5)

${ }^{31}$ JORDÃO NETO (1967:12).
} 
sociólogo conta que em 1919 havia uma crise violenta de falta de "braços" na lavoura e, então, o Estado estimulou a migração interna: - “Em 1919, o próprio governo do estado chegou a mandar uma missão para o Ceará, para recrutar mão de obra”. Já em 1935, o governo do estado de São Paulo celebrou contratos com companhias particulares de imigração e de colonização, com o objetivo de aumentar o número de migrantes nacionais, "mediante uma subvenção oficial”. Essas Companhias iriam aliciar no Nordeste e norte de Minas Gerais pessoas interessadas em vir para São Paulo. "Pagavam a passagem e 60 mil réis por migrante avulso, maior de 12 anos, e 30 mil réis por menores de 3 a 12 anos" (Jordão Neto). Alguns fazendeiros utilizavam-se de um expediente próprio para trazer os migrantes para suas fazendas, em que capatazes ou administradores representantes, solicitavam as passagens ao Departamento de Terras, Colonização e Imigração, indo até o local de embarque / desembarque buscar esses trabalhadores para as fazendas de destino.

Em 1939, o próprio Estado faz esse aliciamento, criando a Inspetoria de Trabalhadores Imigrantes. Os funcionários do Departamento de Imigração e Colonização ficavam instalados nos terminais ferroviários de Montes Claros e de Pirapora, nas localidades portuárias, ao longo do percurso dos "gaiolas" 32 no Rio São Francisco. Os migrantes procedentes do sul da Bahia e do norte de Minas Gerais chegavam à cidade de Montes Claros pelas diversas estradas que para aí, confluíam e onde estava a localizada a estação ferroviária de Montes Claros, estava a final da Ferrovia Central do Brasil e, vindos de lá, embarcavam em direção a estação do Brás, em São Paulo. Os migrantes procedentes de vários estados nordestinos que chegavam às cidades de Juazeiro (Bahia) e Petrolina (Pernambuco) viajavam em vapores, pelo rio São Francisco, e desembarcavam em Pirapora (Minas Gerais) para o início da triagem (ver anexo 2).

Muitos problemas ocorriam nos postos da Inspetoria de Trabalhadores Imigrantes com esses migrantes, como ter que "favorer" algum funcionário, ou então, o constrangimento do assédio sexual. Após essa etapa, as famílias prosseguiam a viagem pela ferrovia até serem recebidas na Hospedaria do Imigrante. Ali os fazendeiros recrutavam os migrantes para trabalhar nas lavouras no interior de São Paulo. Havia uma orientação de que os migrantes não poderiam ficar na Capital e deveriam prosseguir até as fazendas. Esse aliciamento pelo Estado ocorreu até 1943, quando, a Hospedaria passou para o controle do Ministério da Aeronáutica. Entretanto a Inspetoria continuou funcionando e os migrantes que ali chegavam eram alojados em pensões da própria região do Brás, de forma caótica.

\footnotetext{
32 Denominação para os barcos a vapor que transportavam os migrantes nordestinos pelo rio São Francisco, denominados, também de vapores. Cf. Ely Estrela (2003), Gonçalves (2002) e publicação do Memorial do Imigrante (2001).
} 


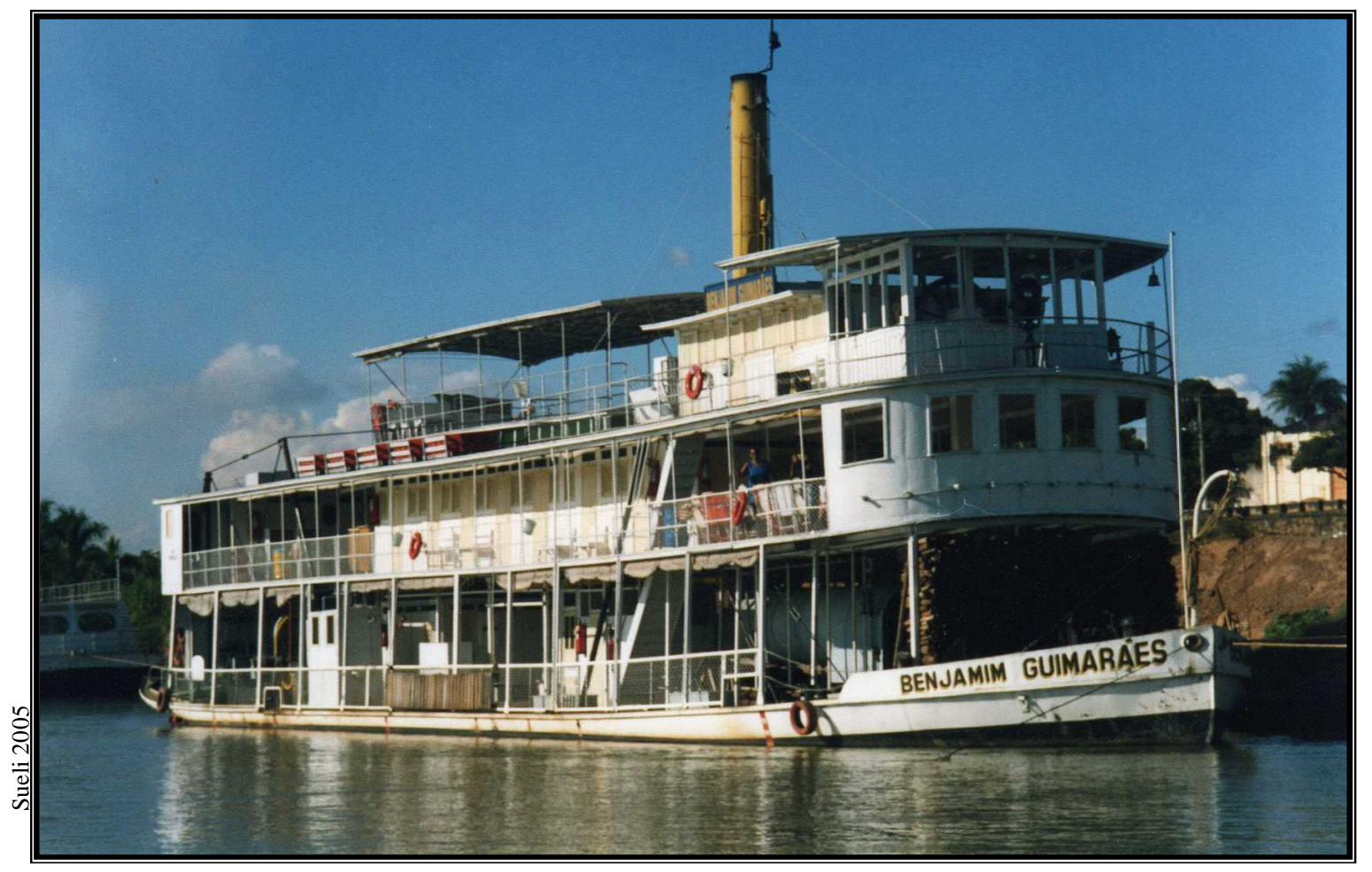

Foto 1: Vapor que transportava os migrantes pelo Rio São Francisco, estacionado na cidade de Pirapora (MG)

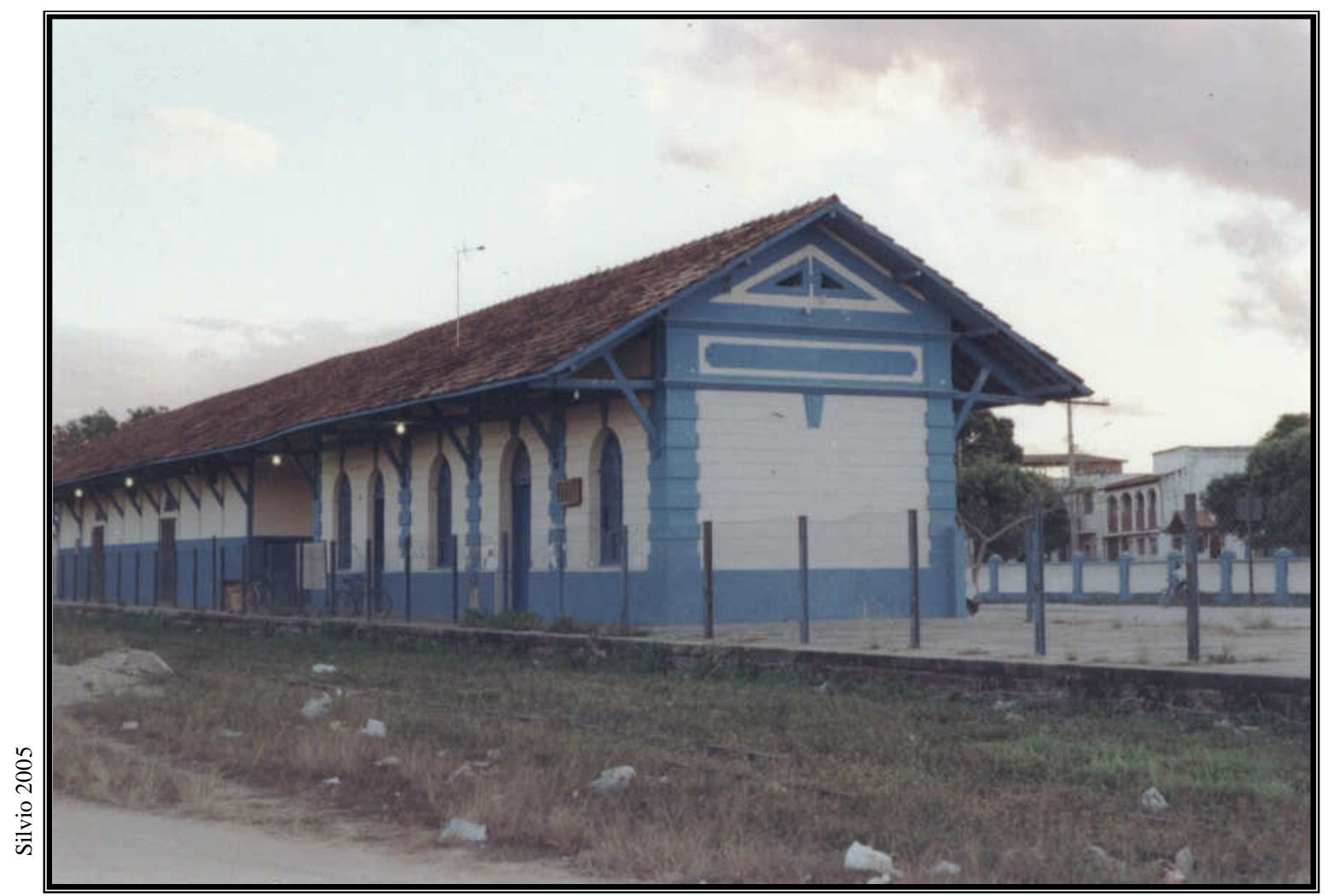

Foto 2: Estação de Trem de Pirapora (MG), local de instalação da Inspetoria de Trabalhadores Imigrantes 


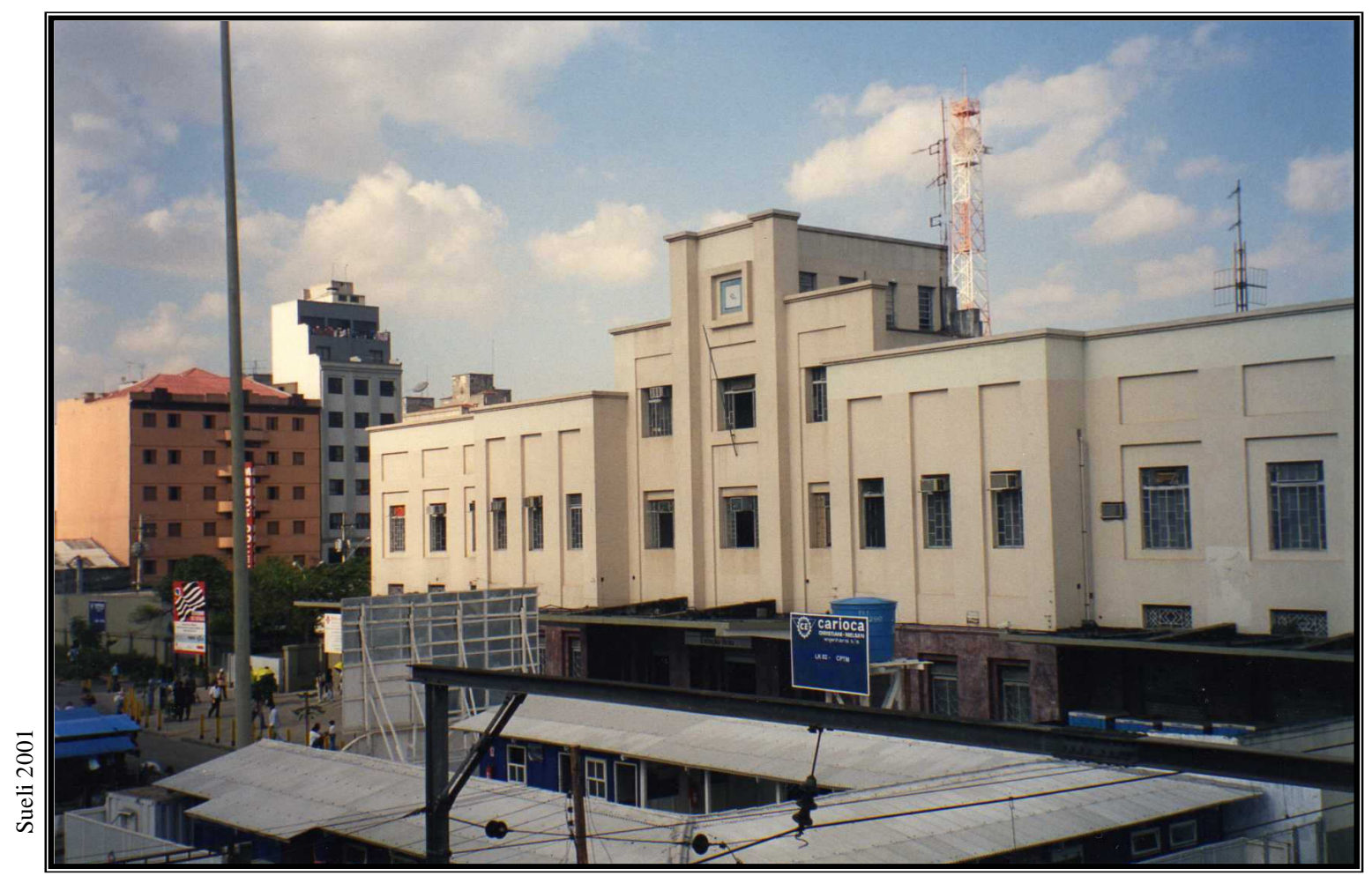

Foto 3: Estação do Brás, denominada na época pelos nordestinos que em São Paulo chegavam de Estação do Norte.

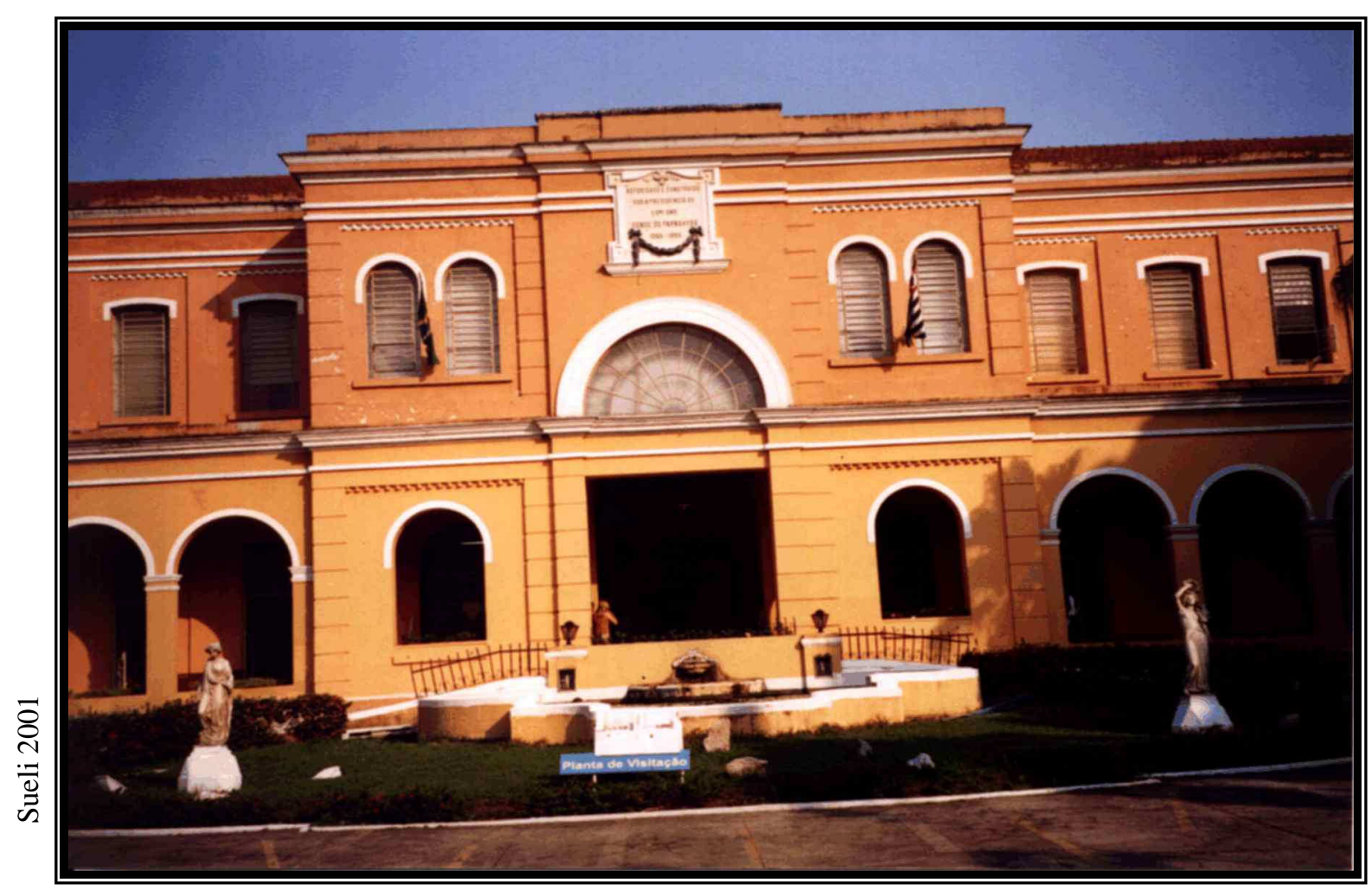

Foto 4: A Hospedaria do Imigrante, fundada em 1887. Hoje é o Memorial do Imigrante. 


\subsection{O território nordestino em São Paulo}

Os nordestinos foram se concentrando no Brás. Os antigos casarões passaram por subdivisões servindo de abrigo para os migrantes que ali residiam e ainda residem, em condições totalmente insalubres: são os cortiços. Assim, o Brás deixou de se destacar como um bairro italiano e passou a ser nordestino. Conforme Ayala (1982:31), "ficou no bairro a 'infra-estrutura' montada para receber, ainda que temporariamente, novos trabalhadores pobres, em seus cortiços, pensões e hotéis de má qualidade que margeiam a estação ferroviária." A autora desenvolveu sua pesquisa sobre os aspectos da cantoria nordestina e em um dos capítulos acaba retratando o Brás como um espaço de encontro dos repentistas nos anos 50, 60 e 70. Ela destaca o espaço simbólico que o Brás representa para os nordestinos. Demarca também, os anos 50 como o "início da nordestinização do Brás".

Os migrantes nacionais, que chegavam na Estação do Brás, que vinham inicialmente para a lavoura, cada vez mais se dirigem para trabalhar na indústria, na construção civil, na limpeza etc, permanecendo na cidade de São Paulo. Esse fluxo de nordestinos permanece até hoje, como tratado anteriormente. Os hotéis e pensões são a segunda forma de abrigar esses nordestinos, adquirindo maior importância com o fim do atendimento da Hospedaria. "As ruas mais próximas da Estação Presidente Roosevelt, nome atual da antiga Estação do Norte, são marcadas pela presença de hotéis e pensões de vários níveis e por um comércio varejista mais popular" (REALE, 1982: 58). Boa parte desses hotéis era controlada por portugueses e espanhóis, assim como os restaurantes. Eram mais de vinte hotéis nos anos 50, sendo que muitos serviam à alta rotatividade e à prostituição. Contam os depoimentos de alguns exproprietários, que um desses hotéis criou um Santuário de Nossa Senhora, para que os nordestinos recém-chegados deixassem uma contribuição para pagar a graça alcançada da “chegada em São Paulo" e esse mesmo hotel "embolsava" a doação.

Na praça, em frente à Estação Ferroviária do Brás, ao lado do Largo da Concórdia, por volta de $1988^{33}$, havia "Kombis" de agenciadores ou "gatos" que ofereciam empregos de vigias, de faxineiros, de caseiros, de trabalhadores na construção civil. Eles agenciavam para dentro e para fora do estado de São Paulo. Nos depoimentos de nordestinos que chegaram em São Paulo nos anos 50, colhidos por Estrela (2003 :183), aparece o registro de agências especializadas "em ludibriar os sertanejos que chegavam" no Brás. Assim, reafirma a autora com dois depoimentos, por ela colhidos:

\footnotetext{
${ }^{33}$ Cf. Trabalho de Campo realizado em 1988.
} 
Tinha no Brás um hotel que chamava Hotel Queiroz, então, eles pegava esse pessoal, que vinha de Imigração, então chegava, vinha o cara, o testa de ferro, chegava lá no hotel: é porque você vai ganhar tanto, vamos com sua mulher, eu pago as passagens e tudo mais, as despesas por consta, vai chegar lá vai trabalhar nisso e naquilo [...]. Lidibriava as pessoas [...]. (Antonio Castro Pereira in ESTRELA, 2003: 215).

O outro depoimento relata a dinâmica e o significado que tinha o Largo da Concórdia, em frente à Estação no Brás:

Ele chegou a São Paulo em princípios da década de 50, quando 'emprego era mato', e os arregimentadores, "os gatos", se postavam na 'Estação do Norte' chamando a atenção dos recém chegados:

- Emprego baiano, emprego baiano... (2003: 178).

Em 1891, as atas da Câmara registram o pedido de providência para os indivíduos oportunistas que se aproveitavam dos recém chegados na estação ferroviária, situação essa retratada no cordel "Brás da Malandragem". O bairro foi caracterizado pela desordem: "aflora o mundo da picardia", "Brás das malandragens, das brigas, das batidas policiais, do "rapa'." (AYALA, 1982: 40). O Largo da Concórdia e a Estação Roosevelt (Estação do Norte) foram primeiras referências para os recém chegados migrantes nordestinos, pois lá ficavam os pontos de parada dos caminhões ${ }^{34}$ e depois dos ônibus. Em 1950, os "paus-de-araras" foram proibidos, embora continuem até meados da década de 50. O primeiro ônibus, que pertenceu ao baiano Altino, saía do Hotel Carioca, para onde retornava lotado. As linhas de ônibus foram ampliadas, principalmente depois que a estrada Rio-Bahia foi asfaltada, na década de 60. As agências de passagens e os pontos rodoviários se concentraram na Rua Cavalheiro, pois até então não estava demarcada a estação rodoviária.

Simultaneamente, houve uma ampliação da frota de ônibus urbanos em virtude da ocupação de loteamentos periféricos da Grande São Paulo. No Largo da Concórdia se concentraram muitos pontos finais de linhas municipais. A interligação do Brás com a periferia de São Paulo fortaleceu o seu centro comercial, voltado para, principalmente, a população nordestina. Como registra Ayala (1982:44):

As imediações da Estação do Norte, mais especificamente o espaço compreendido entre a Avenida Rangel Pestana e a Rua Visconde de Parnaíba, partindo da Almeida Lima, que ladeia a Estação do Norte,

\footnotetext{
34 Os caminhões "pau-de-arara" paravam na rua, em frente a Avicultura Valença do Norte (no Largo da Concórdia, $\mathrm{n}^{\circ}$ 126).O cantor e compositor baiano, de Irará, Tom Zé, compôs a música Correio da Estação do Brás inspirado na Estação do Norte, que veio intitular seu disco, em 1978: "Eu viajo Quinta feira/ Feira de Santana/ quem quiser mandar recado/ Remeter pacote/ Uma carta cativante/ A rua numerada / O nome maiúsculoso...".
} 
começou a ganhar características nordestinas, quer pelos transeuntes, quer pelas lojas de comércio. Pequenas lojas, bazares, bares, casas de lanches, 'Casas do Norte'(vendendo produtos alimentícios regionais), agências de passagens para o Nordeste, pontos de ônibus interestaduais, hotéis e pensões de baixa categoria instalaram-se nesse local.

Atualmente, encontramos nas ruas do Brás, lojas com produtos típicos nordestinos, empresas de ônibus que, no conjunto, caracterizam um terminal rodoviário clandestino ${ }^{35}$; há também transportadoras com seus caminhões, fazendo ligações diretas para o Nordeste e as casas de forrós.

A pesquisa de Jacqz (1982) faz referência à localização de alguns "focos" nordestinos, que evidenciaram certos bairros como "bem nordestinos", em razão dos "trens baianos na estação Roosevelt e à presença das agências de ônibus para o Norte", e continua:

Ali se concentra ainda hoje as lojas tipicamente nordestinas, onde pode se comprar chapéus de vaqueiros, violão e sanfonas, discos de música sertaneja; encontra-se também os ingredientes típicos da comida nordestina, como óleo de dendê, carne de sol, etc... (JACQZ, 1982: 107).

A "Estação do Norte" representava também espaço de lazer, naqueles anos; era o ponto de encontro dos conterrâneos. Muitos nordestinos, que moravam em São Paulo, iam todos os fins de semana, religiosamente, à Estação do Norte para ver os "nortistas chegando" ou então, "marcam encontro na frente da Estação do Norte por causa do vício do tempo do ônibus." (Januário in AYALA, 1982: 44).

Encontramos alguns elementos materializados que marcam, atualmente, a presença nordestina: como a rua Coronel Trancoso, conhecida como a Rua do Forró, com lojas de CDs especializadas em forró, que aos sábados se torna um ponto de concentração, onde nesta rua, também, ocorre um "arrasta pé" no bar Estrela do Forró (Ver foto no 6). Na rua Almirante Barroso está localizada a Editora Luzeiro, especializada em literatura de cordel. Ela existe há 80 anos e pertencia a portugueses, hoje pertence a um paulista.

\footnotetext{
${ }^{35}$ São 35 empresas: 3 delas são registradas e as outras, clandestinas, como foi relatado em um depoimento e constatado em artigo de jornal (Folha de São Paulo - 27.05.2001).
} 


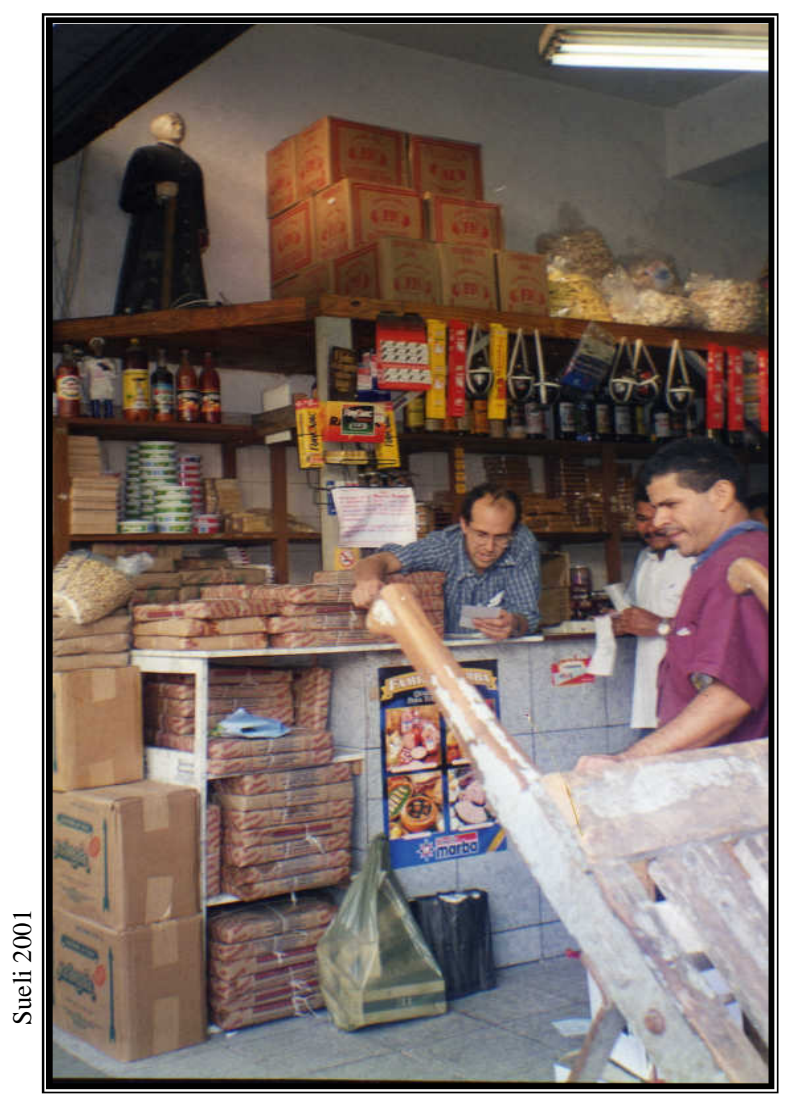

Foto 6: Comércio no Brás voltado para a culinária nordestina com a imagem do Pe. Cícero ao fundo, padroeiro dos nordestinos.

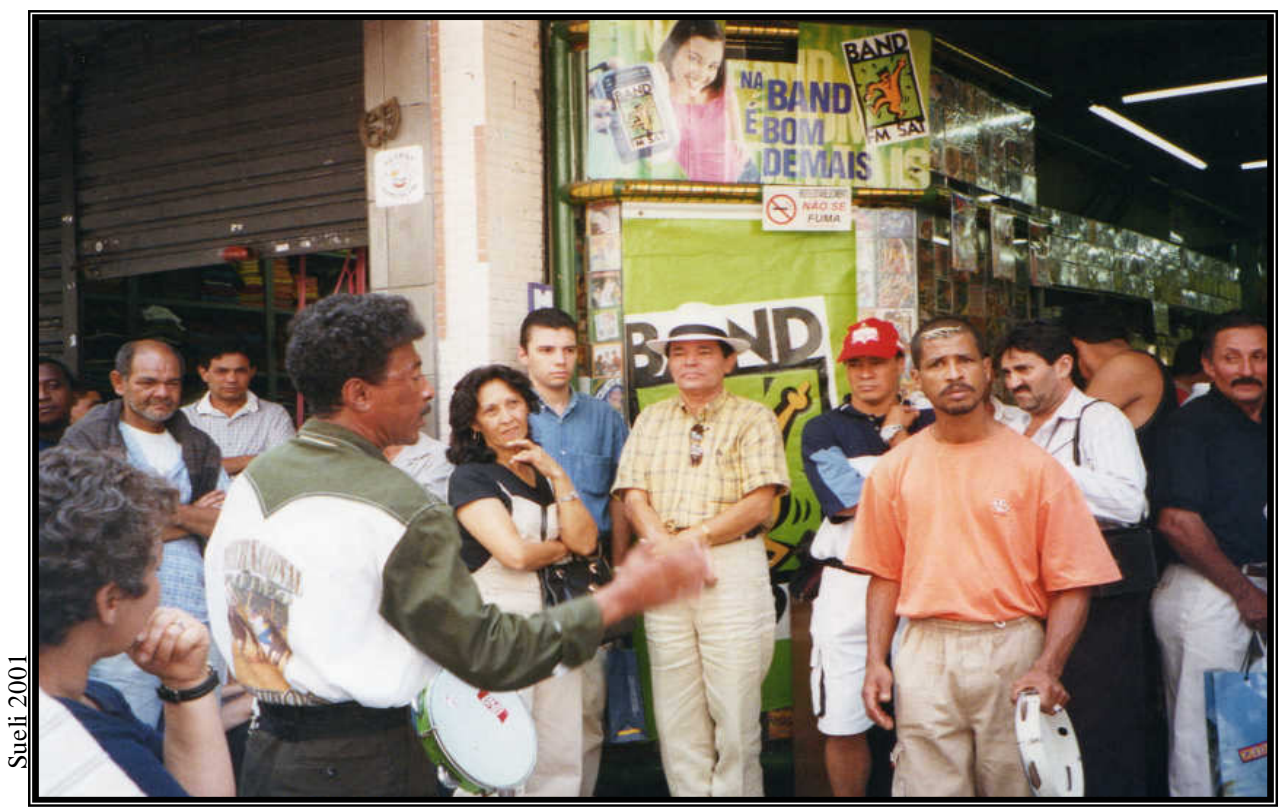

Fotos 7:Emboladores na Rua Coronel Trancoso, conhecida como Rua do Forró, no Brás. 
Nas ruas em torno da estação, o comércio de alimentos e outros artefatos típicos do Nordeste é grande, tomando alguns quarteirões (Ver fotos $\mathrm{n}^{\circ} 5$ e 6). Na rua Gomes Cardim está instalada a sede da ANESP -Associação de Nordestinos do Estado de São Paulo, entidade que existe desde 1987. Ela publica um jornal chamado "Eco- Nordestino" que acaba tendo mais um papel de associação de bairro. Veja parte de seu editorial:

O Eco-Nordestino é o único jornal dirigido à comunidade nordestina e luta pela mesma. Já fora plantado várias árvores em parceria com a Secretaria do Verde e Regional da Sé. Acreditamos que o asfalto da rua Gomes Cardim estará concluído até o final do mês, algumas lixeiras também foram instaladas, a Rua de Cultura e Laser já inauguramos, na rua 21 de Abril, 188 (sic) já inauguramos a biblioteca, sala de computação e a creche já está atendendo 10 crianças e alojamento para algumas famílias. Junto a VITAL TURISMO e outras agências temos conseguido passagens para ajudar alguns conterrâneos a voltar para sua terra natal.

Ao anunciar no Jornal Eco-Nordestino você estará ajudando neste projeto, que é a nossa luta. Não queremos apoio de nenhum Órgão Governamental, só assim nos sentimos livres, o que queremos e o que estamos realizando e levar ao sacoleiro, ao médio e pequeno empresário as empresas aonde eles devem comprar em São Paulo. Pois os ônibus que chegam do norte-nordeste enfim, do Brasil inteiro, são os nossos homens e mulheres que vão gerando renda neste país.

Queremos agradecer aos nossos patrocinadores que é com o anúncio deles que mantemos os nossos projetos, nas mãos das crianças de hoje está o futuro do amanhã que já começou.

(Francis Bezerra, outubro de 2001)

Como o texto mostra, a prefeitura juntou-se com a associação e criou a rua de Cultura e Lazer Nordestina; onde ocorrem brincadeiras para as crianças e forró no palco. $\mathrm{Na}$ inauguração estavam presentes três mil pessoas, segundo o artigo do jornal.

Outros depoimentos mostram o Brás como um local de estudos noturnos, havendo cursos de alfabetização e técnicos, para aquela população não escolarizada que estava chegando na cidade. Dessa forma, o Brás foi se consolidando como um território dos nordestinos.

O desenvolvimento industrial brasileiro impulsionou o acelerado crescimento urbano, próprio da metropolização. A cidade passa então a concentrar o fluxo migratório interno de trabalhadores expulsos do campo. Estes, por sua vez, recriaram os espaços da cidade de São Paulo. Nesse contexto, "até 1940 haviam entrado cerca de 1,2 milhões de migrantes nacionais, principalmente nordestinos, no estado de São Paulo. Daí até 1970 chegariam mais de 4,5 milhões, sendo que 1,5 habitam o município" (MARTIN, 1984: 170). 
Depois dos anos 50, há uma alteração no quadro de registros desses migrantes, que não necessariamente passam pela Hospedaria, porque já têm outros pontos de apoio, como os familiares. A orientação de mandar a pessoa para o Interior de São Paulo deixa de existir e as pessoas acabam permanecendo na Capital, pois o quadro econômico é outro. A situação no campo se modifica: em 1963, vigorar o Estatuto do Trabalhador Rural e não há mais interesse dos fazendeiros em levarem pessoas para morarem nas fazendas, os expulsos tornam-se bóiasfrias, que vão engrossar as periferias das cidades.

BOSCO e JORDÃO NETO (1977) trazem alguns dados sobre a migração dos nordestinos, na qual registra:

A título de ilustração vejamos: dos 404. 960 trabalhadores nacionais chegados a São Paulo entre 1941 e 1949, 94,5\% seriam lavradores. [...] Até 1951, 95\% dos nordestinos dirigiram-se para a lavoura. (BOSCO e JORDÃO NETO, 1967:100).

Vejamos outros dados:

A partir da década de 50, o fluxo de migrantes orienta-se fundamentalmente em direção às cidades, sobretudo para a região metropolitana de São Paulo. Um estudo efetuado numa fábrica paulistana abrangendo os anos de 195658 , revelou que $1 / 4$ dos operários não qualificados e/ou semi-qualificados era formado por nordestinos. (CEM, 1988:8).

O Departamento de Imigração e Colonização passou a atuar na Capital no sentido de atender também dos moradores de rua e dos desempregados. Nos anos 60, houve uma mudança na política de atendimento ao migrante, uma reestruturação ampla que transfere para a assistência social o atendimento. Como bem disse em entrevista Jordão Neto (18.08.95):

O problema surgiu quando a migração deixou de ser uma solução para ser um problema [...]. O Estado investiu, a economia investiu. No momento que deixou de ser uma solução para ser um problema, 'deixou' de haver os serviços.

Outro fator importante no deslocamento dos nordestinos é a mudança do meio de transporte: ferroviário para rodoviário. "Para se ter uma noção da importância da Rio-Bahia como via de 'êxodo', basta atentar para o fato de que em 1950, somente $12 \%$ dos migrantes entravam em São Paulo por via rodoviária; em 1961 cêrca de 34\%”. (BOSCO e JORDÃO NETO,1967: 26). 
Foram muito utilizados os caminhões chamados "paus-de-arara", e posteriormente, ônibus, para a travessia. ${ }^{36} \mathrm{O}$ relato dessas viagens e desse cotidiano encontramos na pesquisa de Estrela (2003) e Zambiasi (2005), revelando diferentes percursos, a alimentação, as bagagens, os vestuários, e as muitas dificuldades sofridas durante a viagem para São Paulo. $\mathrm{O}$ Pe. Alberto Zambiasi e o Pe. Alvírio Morés (2005), enquanto seminaristas, realizaram uma pesquisa, em 1968, em que viajaram no "trem baiano", pela ferrovia Central do Brasil, realizando o percurso de Monte Azul à Estação Roosevelt, de São Paulo, e trouxeram uma série de depoimento e o relato do que era esse deslocamento. Constataram todos os constrangimentos a que os migrantes nordestinos eram submetidos. Esse artigo faz referência aos paus-de-arara e questiona se aqueles que dizem que o migrante é vagabundo "sabem que há 18 caminhões paus-de-arara trabalhando continuamente, dia e noite, no transporte de escravos do Nordeste para o Centro-sul?" Os nordestinos viajavam de 8 a 15 dias, passavam fome, sede, não dormiam, ficavam doentes ou até morriam, conta um agenciador que por, 16 anos alugou 12 paus-de-arara, "convidando" grupos numerosos de nordestinos a migrarem. ${ }^{37}$

O crescimento urbano de São Paulo está relacionado diretamente ao fenômeno migratório, e este, ao processo de industrialização. O fluxo migratório nacional de maior destaque foi o de nordestinos para São Paulo. Da inserção dos migrantes no espaço urbano aparecem os “... contornos físicos e sociais da capital paulista...” (PAIVA, 2004: 271)

Dentre as áreas de concentração de nordestinos, na metrópole de São Paulo muitas conhecidas e estudadas pelos pesquisadores, lembraremos os espaços de maior referência e significado para a comunidade nordestina.

A primeira referência da comunidade nordestina, como tratado anteriormente, foi o bairro do Brás, região central da capital (GOMES, 2002). Com o crescimento urbano surgiram novas áreas de concentração e de referência, nas quais os elementos nordestinos ganham visibilidade.

Rigamonte (2001) identifica esses espaços de concentração como "manchas" ou “pedaços”, apoiada na leitura antropológica de Magnani (1992) ${ }^{38}$ :

\footnotetext{
${ }^{36}$ Ver anexo 2 o Mapa do Roteiro das Migrações para o Estado de São Paulo organizado pela Secretaria da Agricultura, Indústria e Comércio de São Paulo (1951)

${ }^{37}$ ZAMBIASI e MORÉS (2005: 14 -15).

${ }^{38}$ Magnani afirma a respeito de mancha: "Existe uma outra forma de apropriação do espaço quando se trata de lugares, que funcionam como ponto de referência para um número mais diversificado de freqüentadores. Sua base física é mais ampla, permitindo a circulação de gente oriunda de várias procedências. São manchas, áreas contíguas dos espaços urbanos dotadas de equipamentos que marcam seus limites e viabilizam -cada qual com sua especificidade, competindo ou completando - uma atividade ou prática dominante. Numa mancha de lazer, os equipamentos podem ser bares, restaurantes, cinemas, teatros, o café da esquina etc. Os quais seja por competição ou complementação, concorrem para os mesmo efeito: constituem pontos de referência para a prática de determinadas atividades (MAGNANI apud RIGAMONTI, 2001:48). Enquanto que o pedaço é o espaço intermediário entre o privado e o público, onde se desenvolve uma sociabilidade básica,
} 
As marcas da cultura nordestina estão em toda parte: nas Casas do Norte, nos Salões de Baile, em determinadas praças, em lojas de produtos típicos, mercados e feiras. Alguns espaços - seja por razões históricas, seja pela quantidade de pessoas que atraem, ou pela variedade de produtos que oferecem para a venda e o desfrute - são, entretanto, particularmente representativos da presença dos migrantes nordestinos; pode-se dizer que constituem verdadeiras "manchas" no espaço urbano. (RIGAMONTE, 2001: 48).

A autora identifica, na metrópole, alguns espaços ocupados pelos nordestinos como manchas, como, por exemplo, o CTN, Casas do Norte, e outros; e, como pedaço, a Praça Silvio Romero, no Tatuapé. Essas duas áreas foram selecionadas e estudadas por Rigamonte, que identificou diferentes dinâmicas de socialização. Porém, percebemos que tanto a mancha como o pedaço são classificações que partem da premissa da identificação de estratégias de sociabilidade. Sentimos falta nesse conceito uma crítica de como essas relações sociais estão cooptadas pelo processo de metropolização ao capital, desvendando as relações de poder que perpassam por elas, assim, não nos satisfaz essas categorias.

HAESBAERT (2005) identifica uma reterritorialização dos migrantes, marcada por elos de identidade cultural nesses espaços característicos que se formaram. A reterritorialização ocorre por meio das redes regionais ${ }^{39}$ que viabilizam a migração. Diferente de Rigamonte, nós entendemos que esses espaços de aglutinação dos nordestinos na metrópole, na verdade, são territórios, no sentido de sua totalidade, em que vivenciam a experiência integral do espaço em todas as suas dimensões - simbólicas, política, física e econômica -, em que a coesão e o adensamento dos migrantes se dão pela força da identidade e de suas práticas sociais.

A partir de um levantamento dos estudos já realizados sobre os nordestinos em São Paulo, nos diferentes distritos da cidade, identificamos alguns territórios nordestinos. A maioria desses estudos está localizada no município de São Paulo, não encontramos pesquisas que tem o seu empírico em outros municípios que compõem a metrópole, mostrando uma ocupação mais recente da metrópole.

Sobre a Zona Leste da cidade encontramos a obra de Odair da Cruz Paiva (2004) que registrou a ocupação da periferia de São Paulo, a partir da década de trinta, por migrantes nordestinos, especialmente o atual distrito de São Miguel Paulista, estimulada pela implantação da fábrica da Companhia Nitro Química Brasileira (1935). Esse estudo permite identificar as primeiras formas de inserção dos nordestinos em São Paulo, como trabalhadores

mais ampla que a fundada nos laços familiares, porém mais densa, significativa e estável que as relações formais e individualizadas impostas pela sociedade". (RIGAMONTI, 2001:24).

${ }^{39}$ São as redes de migração que ocorrem no interior do Estado -Nação 
operários. Essa fábrica foi fator fundamental para a reconfiguração do espaço no seu entorno e proximidades e estimulou a reapropriação desses espaços pelos nordestinos que se estabeleciam no bairro. Mesmo aqueles que não se inseriram como operários na fábrica encontravam outras formas de inserção, o que o autor denomina, conforme seus depoentes, o encontro entre o sertão e a cidade. Na década de 1940, os dados apontam o crescimento vertiginoso de população nesse distrito e suas proximidades em razão da chegada dos nordestinos na cidade de São Paulo. Assim, loteamentos, muitas vezes clandestinos, distantes 25 quilômetros do centro de São Paulo eram ocupados rapidamente de forma desorganizada.

O autor faz uma relação entre o "Brasil Moderno" e o processo migratório em sua pesquisa. Esse processo aponta para três fatores de entendimento: "sua interface com o desenvolvimento urbano (mão-de-obra e indústria), a reconfiguração do espaço urbano e, por fim, uma nova divisão cultural na cidade”. A mudança na política de incentivo à imigração estimula a mão-de-obra nacional e muda o perfil e a origem do operariado nas fábricas. São Miguel Paulista, por muito tempo, foi denominada de Bahia Nova devido ao grande número de migrantes baianos ou de outros estados do Nordeste. Algumas pesquisas, conforme Paiva $(2002)^{40}$, registram depoimentos nas quais a própria empresa tinha a prática de aliciamento de operários no Nordeste. Eles vinham de caminhão, atraídos por varias promessas; aqui chegando percebiam que as condições eram diferentes do esperado. Após os anos 1940, o recrutamento se restringia apenas a trabalhadores mais qualificados, pois para a mão-de-obra menos qualificada a prática do aliciamento já não era necessária, já havia uma rede de apoio, o que, também, estimulava esse fluxo migratório.

Nas fábricas, os operários nordestinos lembram das péssimas condições de trabalho, periculosidade, regras rígidas, rudeza dos chefes e contramestres, estereótipos criados que os estigmatizavam (Cabeça Chata, Bahia, Farofa...), baixos salários, mas também destacam a série de benefícios oferecidos pela empresa, que nada mais são que os direitos trabalhistas ${ }^{41}$.

Rigamonte (2001) estudou, entre outros pontos, a praça Silvio Romero, localizada no distrito do Tatuapé, na Zona Leste da Cidade. Essa praça tornou-se referência para a comunidade nordestina por ser um ponto de encontro, em que os caminhoneiros e sua frota informal transportam mudanças, encomendas, dinheiro e levam notícias para as áreas de origem dessa comunidade. Esse encontro ocorre aos domingos pela manhã. Existem, também, os espaços de salão de forró, como o CTB (Centro de Tradições Brasileiras),o Gigantão,o

\footnotetext{
${ }^{40}$ ROCHA, Antonia Sarah Aziz. O bairro à sombra da chaminé - um estudo sobre a formação da classe trabalhadora da Companhia Nitro Química Brasileira de São Miguel Paulista (1935 -1960). Dissertação de Mestrado em Filosofia da Educação, São Paulo: PUC, 1992; e FONTES, Paulo.Trabalhadores e cidadãos. Nitro Química: a fábrica e as lutas operárias nos anos 50. São Paulo: Annablume, 1997.

${ }^{41}$ A CLT, governo de Getúlio Vargas (1942).
} 
Centrão. Há, também, como ponto de encontro, o Pavilhão do Nordeste (inaugurado em 1981) ou chamado Mercado Municipal de São Miguel Paulista.

$\mathrm{Na}$ Zona Sul da cidade houve um rápido crescimento urbano atingindo as áreas de mananciais. A especulação imobiliária foi acentuada, expandindo o número de loteamentos clandestinos, desrespeitou a legislação, a fiscalização e ocupou as áreas de proteção aos mananciais, assim explicitando a fragilidade da presença do Estado. Encontramos alguns espaços de referência para a comunidade nordestina, nessas áreas, como assinala o periódico Folha de S. Paulo:

A Prefeitura de São Paulo recebeu denúncias de que até vaquejadas competições entre duplas a cavalo que precisam derrubar um boi, embaladas por forró - ocorrem na área de manancial. Porém, ainda não houve flagrante para punir os organizadores. (F.S.P.08/05/2005).

O evento da vaquejada ocorreu no município de Itapecerica da Serra e o debate sobre o evento apareceu entre os nossos entrevistados na CEAGESP. Identificamos uma diversidade de posições no grupo de nordestinos: muitos contrários ao evento, outros questionando os gastos para a sua montagem ou então, penalizados com a "judiação com os animais". De qualquer maneira, a vaquejada migrou com os nordestinos para São Paulo, contrariando a legislação paulista que proíbe esse evento, por considerar crime contra os animais.

A Praça da Árvore cumpre a mesma função que a praça Silvio Romero, porém em menor escala. O Largo de Santo Amaro é um subcentro comercial que agrega "camelôs" e todo tipo de mercadoria consumida pela comunidade nordestina: desde artigos da culinária nordestina, até as ervas medicinais. Em Santo Amaro (Zona Sul) também temos os grandes salões de forró como o Centro de Lazer Patativa. Silva (2000) registra em sua pesquisa uma rede de canudenses (oriundos de Canudos - BA), concentrada na zona sul da cidade ${ }^{42}$, onde, inclusive, organizou-se uma sede de encontro denominada UPIC - União Pelos Ideais de Canudos.

Para se ter uma dimensão desse universo, Ângelo (1996) afirma que existem mais de 200 pontos de encontro de nordestinos espalhados por toda cidade de São Paulo. ${ }^{43} \mathrm{O}$ autor faz um levantamento minucioso dos restaurantes, casas noturnas, incluindo lojas que vendem

\footnotetext{
${ }^{42}$ Os canudenses além de ocupar os bairros de Jardim São Luís, Jd. Jacira, Jd. Marcelo, Piraporinha, Grajaú, Pq. Santa Madalena, Jd. Ângela, Campo Limpo e Capão Redondo, todos na zona sul da cidade, ocupam, mais espalhados, outros bairros e municípios da metrópole (Taboão da Serra, São Bernardo do Campo, Santo André, São Caetano, Mauá, Guarulhos, entre outros)

${ }^{43}$ Além das centenas de Casas do Norte, espalhadas por toda cidade, destacamos, outros locais de encontro e lazer da comunidade nordestina, como: A Galinhada do Dema (Canindé), o restaurante Andrada (Pinheiros), Recanto do Picuí (Pompéia), Recanto Nordestino (S. Joaquim), Embaixada Nordestina (Osasco), Bambulê, Mercadão da Cantareira, Tropical (Butantã), Brasileirão, Brilho da Lua (Brás- Av. Celso Garcia), Estrela do Forró (Brás- R. Cel Trancoso), O Patativa (Santo Amaro), Prainha do Forró (Guarapiranga).
} 
discos, CDs e livros ligados à cultura nordestina. $\mathrm{O}$ primeiro estabelecimento a ser inaugurado foi o forró de Pedro Sertanejo, no começo dos anos 60.

$\mathrm{Na}$ zona Norte (rua Jacofé), há o concorrido Centro de Tradições Nordestinas (CTN); na zona Leste, o tradicional Forró de Pedro Sertanejo e o Espaço do Forró mantido, este, pela Prefeitura, com entrada grátis. No bairro de Santana, há Um Cantinho do Nordeste e a lanchonete Boa Viagem... (ANGELO,1996:119-120).

O autor completa:

Nesses pontos reúnem-se até 20 mil pessoas a cada fim de semana, chova ou faça sol, frio ou calor. É uma barulheira dos diabos, mas os freqüentadores não ligam, parece até que não se importam muito com o desconforto, que, aliás, é grande. (ANGELO,1996:120).

Rigamonte (2001) com um olhar antropológico, estuda alguns espaços de lazer da comunidade nordestina. Ela remonta aos pequenos bailes familiares, para comemorar aniversários e casamentos que, com o processo de metropolização, transformaram se em salões de forró da cidade. Assim, resgata a história do Forró do Severino, que nasceu em 1971, quando um barraco na favela de Vila Prudente se tornou salão de baile. Até que encerrou suas atividades em 1984, pois o crescimento da cidade impôs um cotidiano que tornou o empreendimento com base na estrutura familiar inviável.

$\mathrm{Na}$ Zona Norte (Z.N.) da cidade, encontramos outro local de referência, espaço com signos que representam a cultura nordestina: o Centro das Tradições Nordestinas. Na entrada há imagens como a de Luiz Gonzaga, Pe. Cícero, Lampião e Maria Bonita em forma de estátuas que remetem a esse campo simbólico. Lá há uma igreja e uma capela que cultuam as figuras de Pe. Cícero e Frei Damião. Há um parque de diversões e jogos, porém o que mais atrai o público são as barracas de comidas típicas nordestinas e os forrós com shows regionais.

Azevedo et al. (1999:42) mostram a dinâmica do CTN, ao definirem esse local: “o CTN foi criado como um espaço comercial, cuja clientela atende especialmente ao apelo de ser ali um lugar de encontro de nordestinos". ${ }^{44}$ Funciona no CTN a radio Atual que juntamente com programas de outras rádios (Imprensa, Bandeirantes, Tropical, Capital) ${ }^{45}$, está voltada para o público nordestino.

\footnotetext{
${ }^{44}$ Hoje o CTN apresenta uma diminuição na freqüência, segundo o depoimento, já chegou a reunir 40 mil pessoas, quando Frei Damião veio a São Paulo.

${ }^{45}$ A rádio Capital possui um programa chamado "São Paulo - Capital - Nordeste" apresentado por Assis Ângelo.
} 


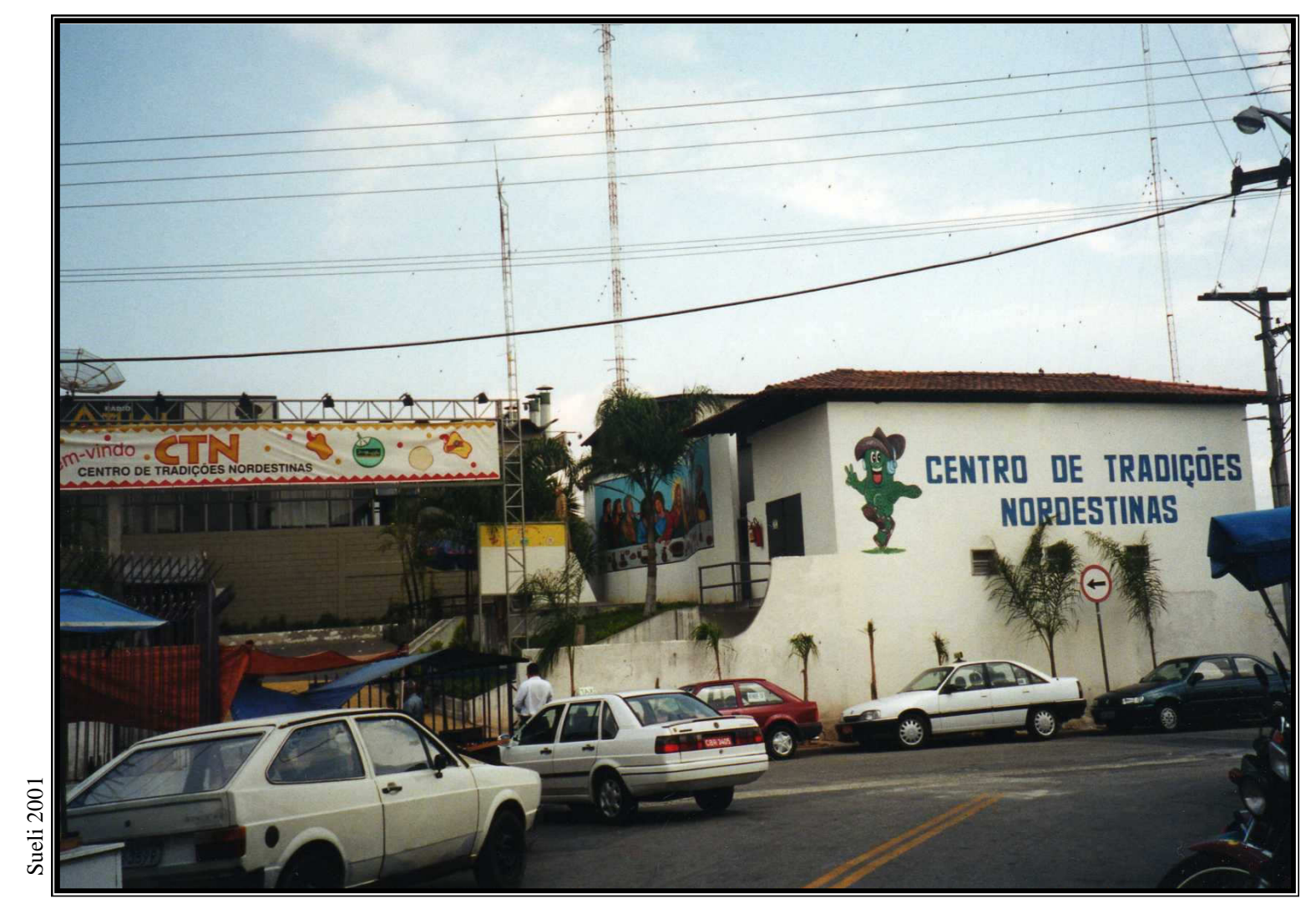

Foto 7 : Centro das Tradições Nordestinas em São Paulo.

Não podemos deixar de mencionar, ainda, a Praça da Sé e o Parque Ibirapuera ${ }^{46}$ como pontos de encontro de migrantes nordestinos. Em 1978, o Terminal Rodoviário da Luz começou a receber os migrantes nordestinos, os quais acabaram se instalando naquela região e proximidades. A rodoviária foi transferida, para o terminal Interestadual do Glicério, provisoriamente, onde também se encontra forma de ocupação nordestina nos arredores. Em 1982, o Terminal Rodoviário foi novamente, transferido para o Tietê e o processo de fixação do migrante nordestino nas proximidades do ponto de chegada se repetiu. Desse modo, os locais determinados pelo transporte, a exemplo do que aconteceu no passado com a Estação do Brás e com o Largo da Concórdia, acabam se tornando referências para os migrantes.

A pesquisadora Rosani C. Rigamonte (2001) organizou um inventário de locais onde as práticas de lazer e de sociabilidade ocorrem na metrópole paulistana, o que permitiu a elaboração de um mapa dos nordestinos na metrópole e suas formas de ocupação (ver anexo $3)$.

\footnotetext{
${ }^{46}$ Esses espaços foram bastante mencionados por migrantes recém chegados, alojados no albergue Casa do Migrante, em entrevistas obtidas pelo Grupo de Estudos Migratórios do Labur/USP e CEM.
} 
Os caminhoneiros da Praça Silvio Romero vão buscar, muitas vezes, as encomendas nas casas dos migrantes. Tal fato nos permite identificar também os locais de moradia dos migrantes que usam desse expediente. Segue abaixo alguns dados, em que se identifica a cidade de origem dos migrantes, no Estado da Bahia, e a atual residência em São Paulo:

\section{Tab. 2: Origem e residência do migrante}

\begin{tabular}{|l|l|}
\hline Município de origem do migrante: & Local de residência na metrópole: \\
\hline Piripá, Tremendal & Vila Formosa (ZL) \\
\hline Jânio Quadros & Itaim Paulista (ZL) \\
\hline Condeúba, Piripá, Tremendal & Guainazes (ZL) \\
\hline Piripá, Caculé, Cordeiro & Campo Limpo (ZS) \\
\hline Piripá & Jardim Santa Catarina (ZS) \\
\hline Piripá, Tremendal & Parque do Carmo (ZL) \\
\hline Belo Campo & Pinheiros (ZO) \\
\hline São João do Paraíso & Lapa (ZO) \\
\hline Piripá, Tremendal & Jardim Imperador (ZL) \\
\hline Lagoa Preta, Piripá, Lagoa Grande & Brasilândia (ZN) \\
\hline Piripá & Jardim Boa Vista (ZL) \\
\hline
\end{tabular}

A autora enumera uma série de pontos espalhados pela cidade de São Paulo ${ }^{47}$, que vale a pena listarmos novamente, pois são também "nós" de concentração de nordestinos, para seguirmos o propósito desse capítulo: Largo da Batata (Pinheiros), Largo do Japonês (Cachoeirinha), Largo do Limão, Largo do Socorro, Largo Nossa Senhora do Ó, Largo São Matheus, Largo Treze de Maio (Santo Amaro), Mercado da Penha, Parque da Aclimação, Parque da Conceição (Jabaquara), Parque da Luz, Parque do Piqueri, Parque Dom Pedro, Parque Fernando Costa (Água Branca), Parque Pirituba, Praça da Árvore (denominada no final dos anos 70 como a Embaixada dos Baianos), Praça Silvio Romero (Tatuapé), Santana (Terminal de ônibus). Normalmente, os terminais de ônibus e trem são espaços de aglutinação dos migrantes, onde esses instalaram-se como "camelôs" e comercializa-se a pinga, o churrasquinho, a tapioca, entre outros.

\footnotetext{
47 A autora tenta construir um mapa "Pontos de Referência: migrantes nordestinos pela cidade" em que encontramos uma lista ampliada dos locais citados acima.
} 
O importante desse inventário é lembrar que muitas vezes a paisagem se repete, as barracas de "camelôs", as comidas típicas e, a paisagem sonora, pois, há sempre alguém comercializando música. Para vender CDs, fitas cassete e discos, é colocada uma pequena caixa de som ligada no volume máximo, o que possibilita identificar ritmos e estilos do público nordestinos.

Outro aspecto fundamental é que os espaços de lazer são, simultaneamente, espaços de trabalho. Nesses locais realizam-se compras, vendas, trocas, encontros, informações de emprego, e, principalmente, onde o desemprego se materializa e obriga a várias outras formas de inserção do migrante na cidade.

Os nordestinos, na sua maior parte, residem, tanto nas periferias como nos centros deteriorados, nos cortiços, nas diversas favelas da metrópole ${ }^{48}$, por serem estas alternativas de moradia barata. À procura de preços baixos dos terrenos eles rumam para os loteamentos clandestinos, as áreas de risco e insalubres, e conjuntos habitacionais ${ }^{49}$. Segundo pesquisa da Datafolha, $41 \%$ dos moradores da área Sé/Brás (distritos do Brás, Bom Retiro, Cambuci, Pari e Sé) são nordestinos. É o maior índice das 19 áreas do município pesquisadas (F.S.P. 25/01/2004).

\footnotetext{
${ }^{48}$ Lembrando a pesquisa de BAPTISTA (1998) que estudou uma rede social de nordestinos na favela de Jardim Colombo (Zona Sul).

${ }^{49}$ DAMIANI (1994) e RODRIGUES (1991)
} 


\section{Mapa 1:}

\section{MIGRANTES NORDESTINOS NO MUNICÍPIO DE SÃO PAULO}

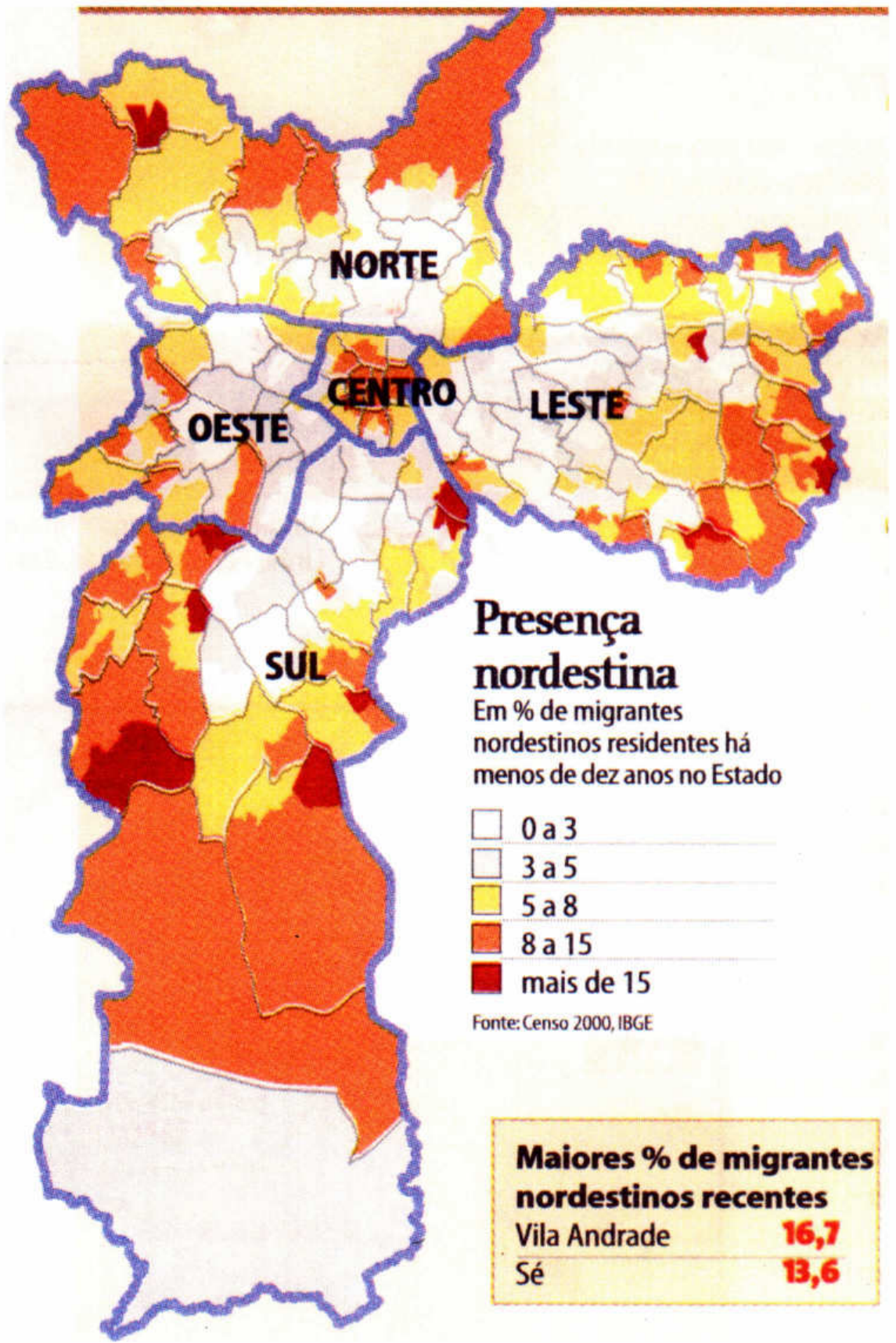

Fonte: Folha de São Paulo, 09 de fevereiro de 2004. Caderno Especial.Mapas

Existe uma série de estudos que contam a saga dos nordestinos em São Paulo, estivemos em contato com alguns deles como os artigos de Albuquerque Jr. (1990) e Menezes (1990). Esses autores pesquisam a migração de nordestinos para São Paulo e Rio de Janeiro, 
na perspectiva de entender a sua inserção no mercado de trabalho. O primeiro autor buscou compreender a formação de estereótipos dos migrantes - Baianos e Paraibanos - e como eles se identificam ou não, com a classe operária destas duas cidades; a segunda autora, que discute a corrente migratória de paraibanos para São Paulo e o seu retorno, faz uma investigação sobre a busca do migrante que almeja o trabalho por conta própria. Outras pesquisas mais recentes continuaram a estudar esse fluxo migratório como: Bison (1995) que estudou a migração das empregadas domésticas do Vale do Jequitinhonha (MG) para São Paulo; outra pesquisa em destaque é a de Estrela (2003), que estudou o fluxo de baianos que migraram para São Paulo e depois retornaram, os chamados "Sampauleiros". Para entender esse fluxo, a autora examinou aspectos do cotidiano dessa migração bem como suas representações.

Esses estudos tratam do migrante que chega em São Paulo com pouca ou nenhuma escolaridade; que, na maior parte das vezes, trabalha na construção civil ou no serviço doméstico, e que vai morar em pensões, cortiços ou favelas, que enfrenta as dificuldades de andar na grande cidade e que sente saudades do local de origem.

Ângelo (1996: 85) faz a seguinte afirmação

[...] a Capital paulista, aliás, transformou-se nesta segunda metade do século numa espécie de extensão do Nordeste, tanto que estatisticamente é a cidade brasileira que tem o maior número de nordestinos residentes ou em trânsito: cerca de 6 milhões, incluindo descendentes.

Para dimensionarmos o universo de nordestinos na Grande São Paulo apresentamos algumas referências e dados encontrados: em Baptista (1998:32), que informa sobre a participação dos migrantes nordestinos, no total de migrantes em São Paulo em diversos períodos, vejamos: em 1950, era de 27,8\%, em 1974 de 49\%, em 1982 de 56\% e em 1997 de 46\%; os dados referentes ao censo demográfico de 2000, divulgados pelo IBGE, apresentam 3.641 .148 nordestinos, que representam $20 \%$ da população da região metropolitana paulista. Esses dados consideram o lugar de nascimento da população residente na Metrópole. A Fundação SEADE revela ${ }^{50}$ que, no mesmo censo:

A Região metropolitana de São Paulo (RMSP) recebeu cerca de $720 \mathrm{mil}$ migrantes de outros Estados brasileiros, o que corresponde a praticamente $58 \%$ do total de pessoas que chegaram ao Estado de São Paulo entre 1995 2000. Para a metrópole, prevalecem os fluxos do Nordeste $(72,8 \%)$, principalmente os originários da Bahia $(29,1 \%)$ e Pernambuco $(14,1 \%)$, vindo a seguir os procedentes de Minas Gerais (10,2\%). A capital paulista recebeu quase 410 mil migrantes, praticamente $57 \%$ do total de pessoas que

\footnotetext{
${ }^{50}$ Fonte: SP Demográfico. Setembro de 2003
} 
chegaram à RMSP, destacando-se os fluxos com origem no Nordeste $73,1 \%$ ) e, a seguir, nas Regiões Sudeste e Sul. Dos que se dirigiram para a capital, destacaram-se os provenientes da Bahia (30\%), Pernambuco $(13,1 \%)$ e Minas Gerais $(9,6 \%)$.

Veja os gráficos a seguir:

Gráfico 1: Migrantes Interestaduais, segundo Local de Origem (em \%)

Estado de São Paulo - 1986-1991 e 1995-2000

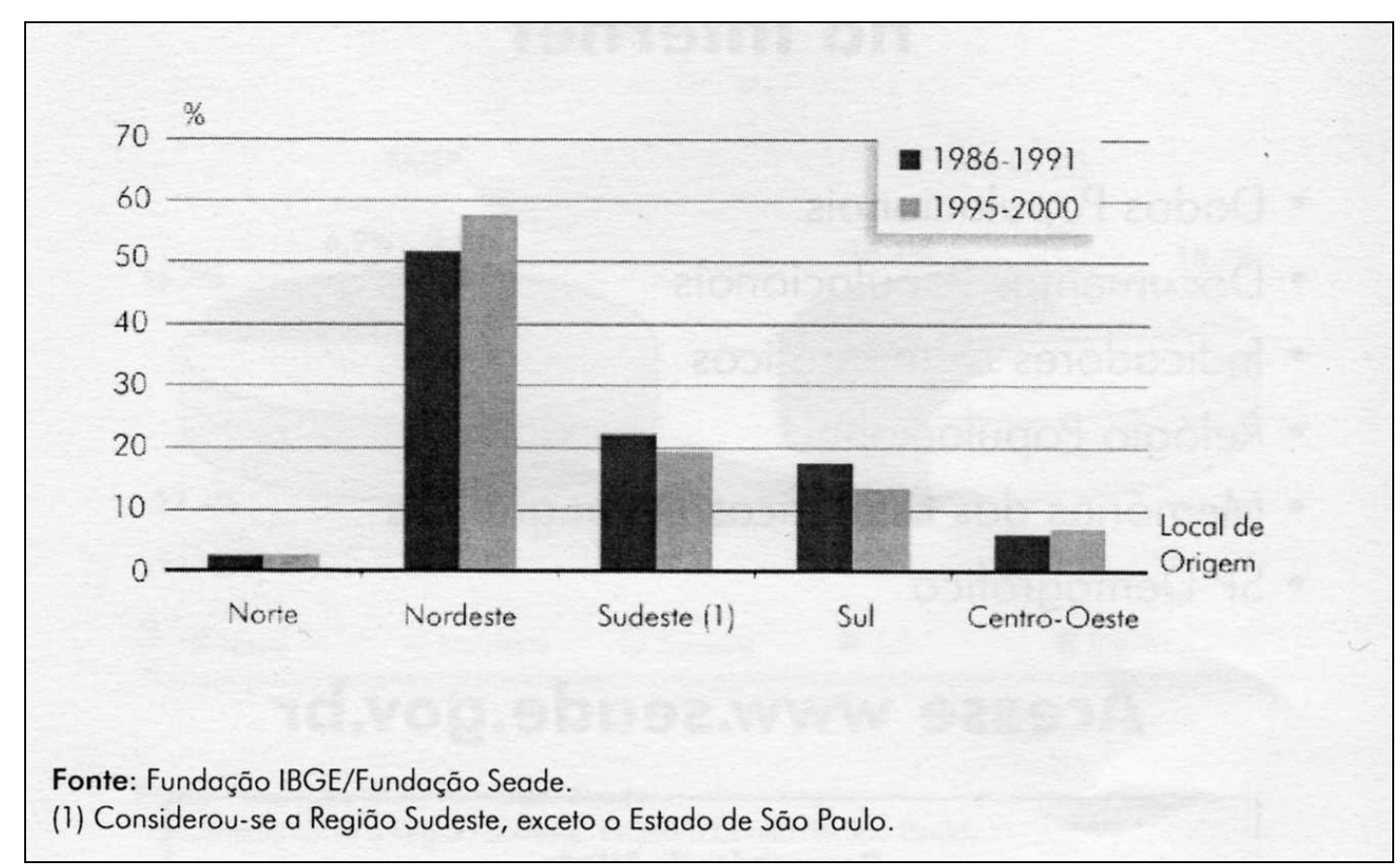

Gráfico 2: Migrantes Interestaduais, segundo Local de Origem (em\%) RMSP e Interior - 1995-2000

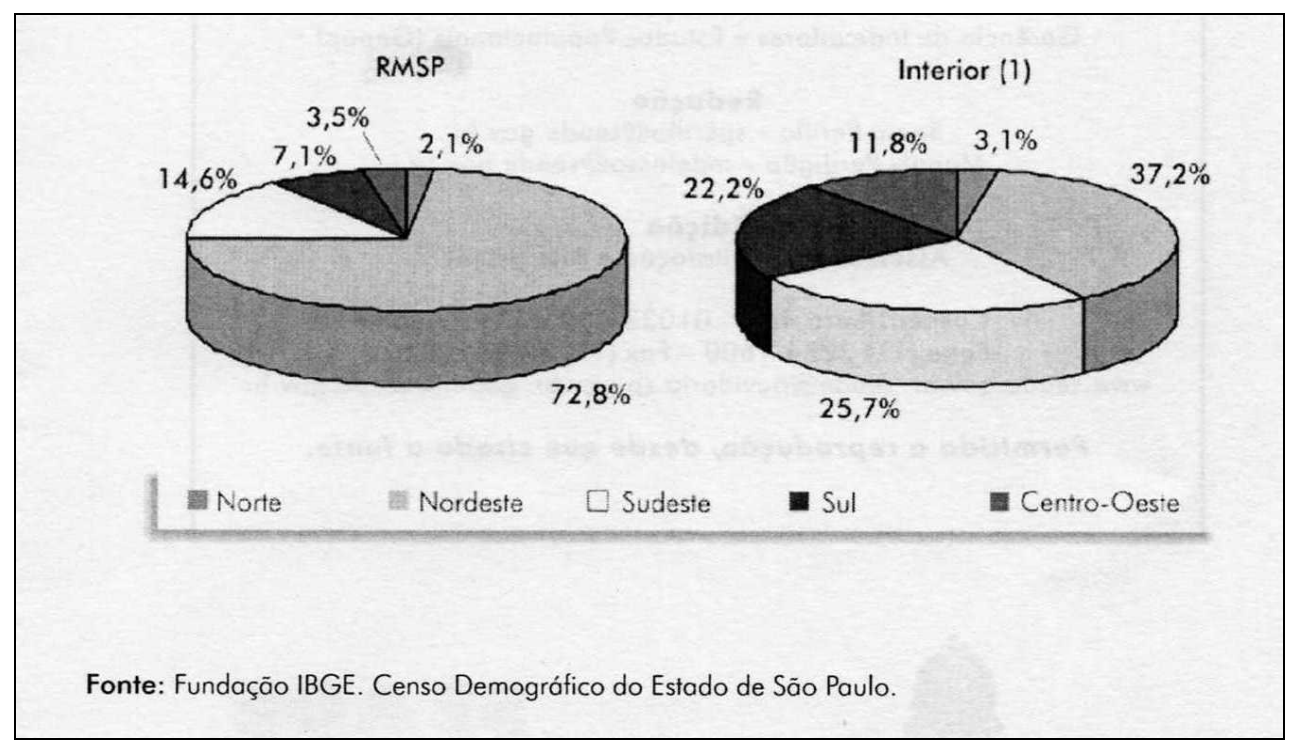


Os dados do censo 2000 (IBGE) considera migrante, as pessoas não residentes no município em 01/09/1991, com 4 anos ou mais de idade. ${ }^{51}$. Em nossa pesquisa consideramos como migrante nordestino, não apenas o recém chegado, mas todo universo de nordestinos, incluindo, os seus descendentes, que mantêm manifestações de uma cultura nordestina, mesmo que apresente forma residual. O critério determinado pelo IBGE - Instituto Brasileiro de Geografia e Estatística - que considera o migrante a pessoa não residente no município em 01/09/91, restringe o conceito de migrante. Outro problema apresentado nesse universo é o fato de o Instituto considerar migrante, aquele que muda de residência de um município vizinho a outro, mesmo que seja a curta distância. Nessa circunstância devemos relativizar esses indicadores obtidos pelo IBGE. Apesar de diferenças conceituais foi possível construir a seguinte tabela, que mostra em linhas gerais, o número de migrantes nordestinos na Região Metropolitana da Grande São Paulo e os estados de origem, do último censo demográfico.

\footnotetext{
${ }^{51}$ Essa pesquisa foi realizada em 2001 no site do IBGE( www.ibge.gov.br) O corte em 01/09/91 para efeito de coleta da informação, se dá em função da data de referência do censo demográfico de 1991, o que permitiu avaliar o movimento migratório neste intervalo, segundo os dados do IBGE na contagem da população.
} 
Tab. 3: Migrantes nordestinos recentes na metrópole da Grande São Paulo, 1991 - 2000

\begin{tabular}{|c|c|c|c|c|c|c|c|c|c|c|}
\hline & $\mathbf{M ~ A ~}$ & PI & $\mathbf{R N}$ & $\mathbf{A L}$ & PB & SE & BA & PE & $\mathbf{C E}$ & Total: \\
\hline Arujá & 47 & 64 & 26 & 100 & 83 & 51 & 709 & 355 & 96 & 1531 \\
\hline Barueri & 199 & 790 & 199 & 652 & 368 & 166 & 2722 & 1580 & 762 & 7438 \\
\hline Biritiba-Mirim & 2 & & 3 & 20 & 10 & 2 & 93 & 63 & 1 & 194 \\
\hline Cajamar & 33 & 103 & 105 & 83 & 58 & 43 & 604 & 650 & 69 & 1748 \\
\hline Carapicuíba & 279 & 965 & 433 & 980 & 707 & 230 & 4596 & 1709 & 1084 & 10983 \\
\hline Caieiras & 40 & 74 & 43 & 170 & 18 & 17 & 639 & 324 & 171 & 1496 \\
\hline Cotia & 63 & 243 & 126 & 286 & 220 & 96 & 1552 & 588 & 237 & 3411 \\
\hline Diadema & 525 & 905 & 276 & 869 & 831 & 185 & 4940 & 2890 & 2171 & 13592 \\
\hline Embu & 161 & 412 & 199 & 582 & 4547 & 134 & 520 & 1195 & 775 & 8525 \\
\hline Embu Guaçu & 4 & 17 & 14 & 63 & 46 & 18 & 492 & 225 & 91 & 970 \\
\hline Franco da Rocha & 121 & 325 & 127 & 485 & 300 & 60 & 1519 & 837 & 336 & 4110 \\
\hline Francisco Morato & 178 & 433 & 119 & 571 & 357 & 97 & 2237 & 1010 & 530 & 5532 \\
\hline F. Vasconcelos & 149 & 188 & 67 & 478 & 318 & 87 & 1992 & 1027 & 487 & 4793 \\
\hline 1Guararema & 5 & - & 12 & 07 & 08 & 02 & 64 & 31 & 18 & 147 \\
\hline Guarulhos & 1159 & 1587 & 1138 & 3624 & 2521 & 867 & 17465 & 11230 & 4093 & 43684 \\
\hline Itapevi & 107 & 438 & 93 & 381 & 247 & 65 & 1732 & 833 & 464 & 4360 \\
\hline Itap. da Serra & 90 & 136 & 111 & 259 & 242 & 80 & 1822 & 810 & 397 & 3947 \\
\hline Jandira & 44 & 224 & 54 & 271 & 204 & 22 & 930 & 430 & 248 & 2427 \\
\hline Itaquecetuba & 338 & 526 & 172 & 768 & 574 & 194 & 4616 & 2156 & 919 & 10263 \\
\hline Juquitiba & 14 & 7 & 2 & 117 & 53 & 3 & 345 & 90 & 52 & 683 \\
\hline Mauá & 269 & 1382 & 173 & 1018 & 763 & 202 & 3775 & 2699 & 836 & 11117 \\
\hline Mairiporã & 27 & 49 & 38 & 150 & 59 & 58 & 784 & 257 & 107 & 1529 \\
\hline Mogi das Cruzes & 96 & 200 & 213 & 445 & 346 & 107 & 1731 & 934 & 417 & 4489 \\
\hline Osasco & 532 & 3809 & 431 & 1603 & 1131 & 334 & 6026 & 3252 & 2026 & 19144 \\
\hline Pirap. Bom Jesus & - & 8 & - & 15 & 7 & - & - & 48 & 3 & 81 \\
\hline Poá & 45 & 84 & 36 & 77 & 38 & 27 & 541 & 296 & 160 & 1304 \\
\hline Ribeirão Pires & 47 & 136 & 47 & 221 & 135 & 66 & 682 & 320 & 233 & 1887 \\
\hline Rio G. da Serra & 19 & 71 & 19 & 140 & 45 & 37 & 251 & 281 & 104 & 967 \\
\hline Salesópolis & - & - & 3 & 5 & - & 4 & 70 & 22 & 3 & 107 \\
\hline Santa Isabel & 7 & 8 & 38 & 27 & 54 & 7 & 294 & 125 & 61 & 621 \\
\hline San. do Parnaíba & 37 & 290 & 49 & 314 & 112 & 41 & 822 & 595 & 221 & 2481 \\
\hline Santo André & 250 & 1401 & 287 & 1030 & 906 & 267 & 4645 & 3353 & 937 & 13076 \\
\hline S. B. do Campo & 539 & 1928 & 625 & 967 & 2126 & 283 & 6821 & 3813 & 2723 & 19825 \\
\hline S. C. do Sul & 89 & 271 & 51 & 76 & 287 & 28 & 749 & 516 & 159 & 2226 \\
\hline São Paulo & 9441 & 15899 & 8001 & 19367 & 18989 & 5832 & 112561 & 50809 & 30893 & 271792 \\
\hline S. Louren. Serra & 18 & 73 & 28 & 259 & 177 & 79 & 616 & 376 & 99 & 1725 \\
\hline Suzano & 133 & 195 & 107 & 419 & 227 & 99 & 1420 & 1058 & 429 & 4087 \\
\hline Taboão da Serra & 201 & 398 & 171 & 389 & 404 & 144 & 3640 & 707 & 605 & 6659 \\
\hline Vargem G. Pta. & 10 & 12 & 19 & 62 & 52 & 22 & 289 & 125 & 53 & 644 \\
\hline Subtotal & 15318 & 33651 & 13655 & 37350 & 37570 & 10056 & 195306 & 97619 & 53070 & - \\
\hline TOTAL: & & & & & & & & & & 493595 \\
\hline
\end{tabular}

Dados preliminares do Censo de 2000 - IBGE, em que considera pessoas não residentes no município em 01/09/1991, com 4 anos ou mais de idade.

Fonte: www.ibge.gov. br

Elaboração: Sueli de Castro Gomes 
Pela Tabela, dentre outras considerações pode-se constatar que:

- O maior grupo de migrantes nordestinos para a Metrópole continua a ser o dos baianos (195.306); seguido por pernambucanos (97. 619); em terceiro lugar encontram-se os cearenses (53. 070), quarto lugar os paraibanos (37. 570); quinto colocado estão os alagoanos (37. 350 migrantes); sexto lugar estão os piauienses (33 651), sétimo lugar no ranking, ficam os maranhenses (15.318), oitavo os "potiguás" (13. 655) e em nona colocação e última os sergipanos (10. 056).

- O Município de São Paulo, continua a receber migrantes nordestinos em maior número por razões sócio-econômicas e históricas, atraindo 271.792 nordestinos. Entretanto, destacam-se alguns municípios na Metrópole, como áreas de maior concentração de nordestinos: em primeiro lugar, Guarulhos, que atraiu 43.684 nordestinos; em segundo lugar está o município de São Bernardo do Campo com 19. 825 nordestinos; em terceiro, segue o município de Osasco com o universo de 19.144 nordestinos; depois em quarta posição está Diadema (13.592 nordestinos), em quinto lugar encontra-se Santo André (13.076 nordestinos), em sexta posição está Mauá (11.117 nordestinos); em sétimo lugar, o município de Carapicuíba, com um total de 10.983 nordestinos.

- Enquanto a maioria dos municípios que compõem a metrópole apresenta um quadro comum no ranking de participação de migrantes nordestinos em que em primeiro lugar sempre estão, os baianos, em segundo colocado, estão os pernambucanos e em terceiro, os cearenses; ocorre um diferencial no município de Osasco em relação aos outros municípios da metrópole, pois o segundo grupo mais numeroso, nesta cidade, são os piauienses (3.800) e ultrapassando a presença dos pernambucanos (3.252). Depois do município de São Paulo que atraiu 15.899 piauienses, segue o município de Osasco que atraiu 3809 migrantes piauienses. Esses dados mostram que existe um grande número de piauienses concentrados em Osasco no território da metrópole paulistana. No andamento da pesquisa, em observações de campo, encontramos um vereador de Osasco, oriundo do Piauí, Aluísio Pinheiro, do Partido dos Trabalhadores, participando dos eventos do Sindicato dos Carregadores, na CEAGESP, pois a maioria dos carregadores, piauienses, reside em Osasco. Assim, podemos constatar a territorialidade dos piauienses no município de Osasco e que esses possuem um representante conterrâneo no poder público municipal.

No município de São Paulo, a comunidade nordestina está sendo cada vez mais lembrada pelo poder público, pois foi instituído, oficialmente, o Dia do Forró como 13 de dezembro, de acordo com a Lei municipal $n^{\circ} 13.901$ de autoria da vereadora Tita Dias, que passou a constar no calendário de eventos do município de São Paulo. Lei que passou a 
vigorar em 2004. A data foi escolhida por ser o dia de nascimento de Luiz Gonzaga, cantor, criador e divulgador do forró. A Ex-Vereadora Tita Dias faz a seguinte declaração:

Propor o Dia do Forró é reconhecer a influência da cultura nordestina na cidade de São Paulo. É abraçar esses filhos de outras terras, migrantes, que através da cultura nordestina se misturam aos sudestinos e se integram com o Brasil todo. Quanto mais orgulhosos somos de nossa cultura, com mais veemência atuamos como cidadãos. ${ }^{52}$

Partindo dos dados das tabela acima, construímos dois mapas com o propósito de visualizar a presença nordestina na Metrópole e perceber os novos espaços de ocupação desse grupo de migrantes. Veja os mapas nas páginas que se seguem.

\footnotetext{
${ }^{52}$ Fonte:www.rebele-se.org.br (da Vereadora Tita Dias) consulta dia 20/12/2004.
} 


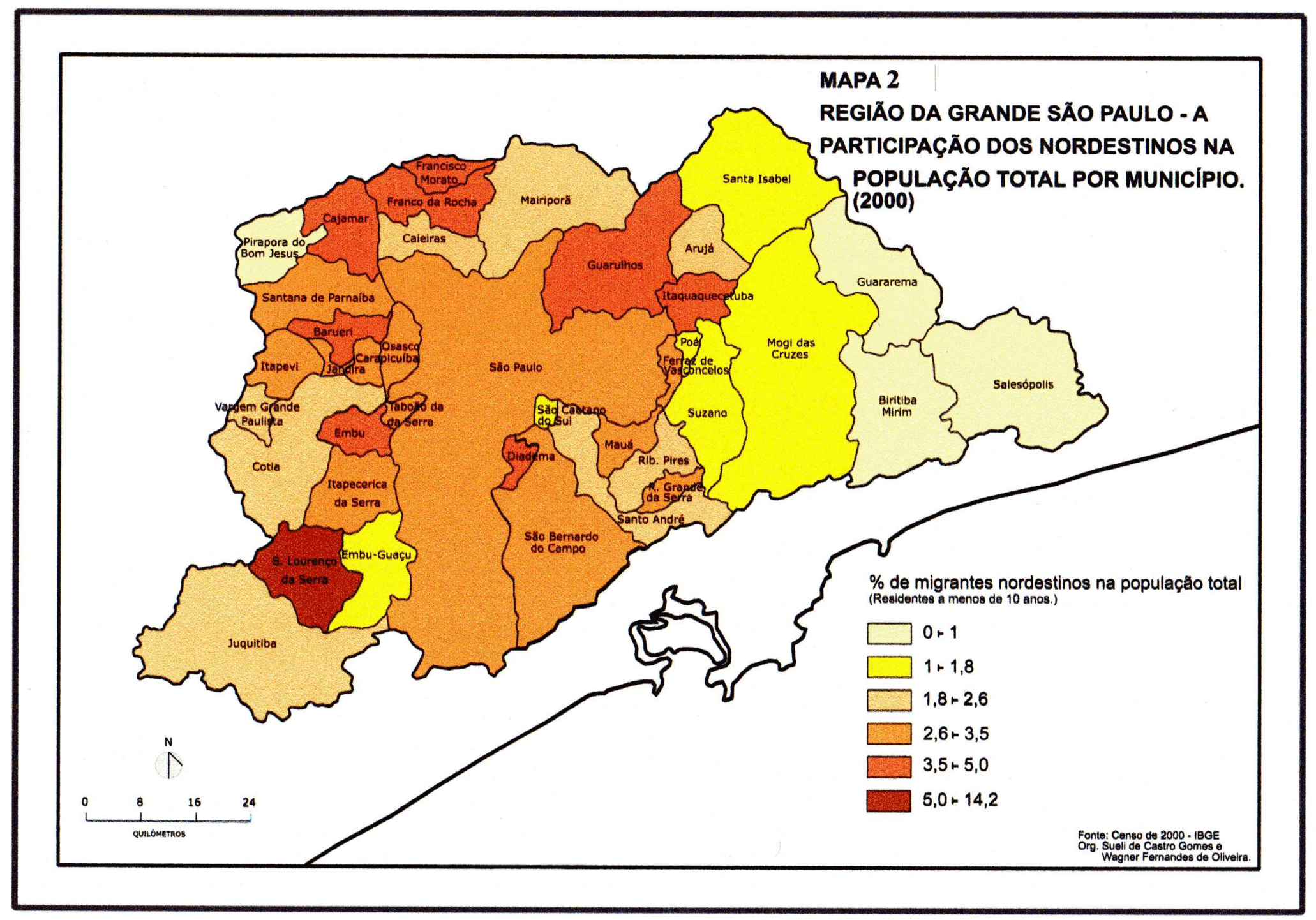


Mapa 3 - Região da Grande São Paulo - Migrantes Nordestinos Residentes por Município

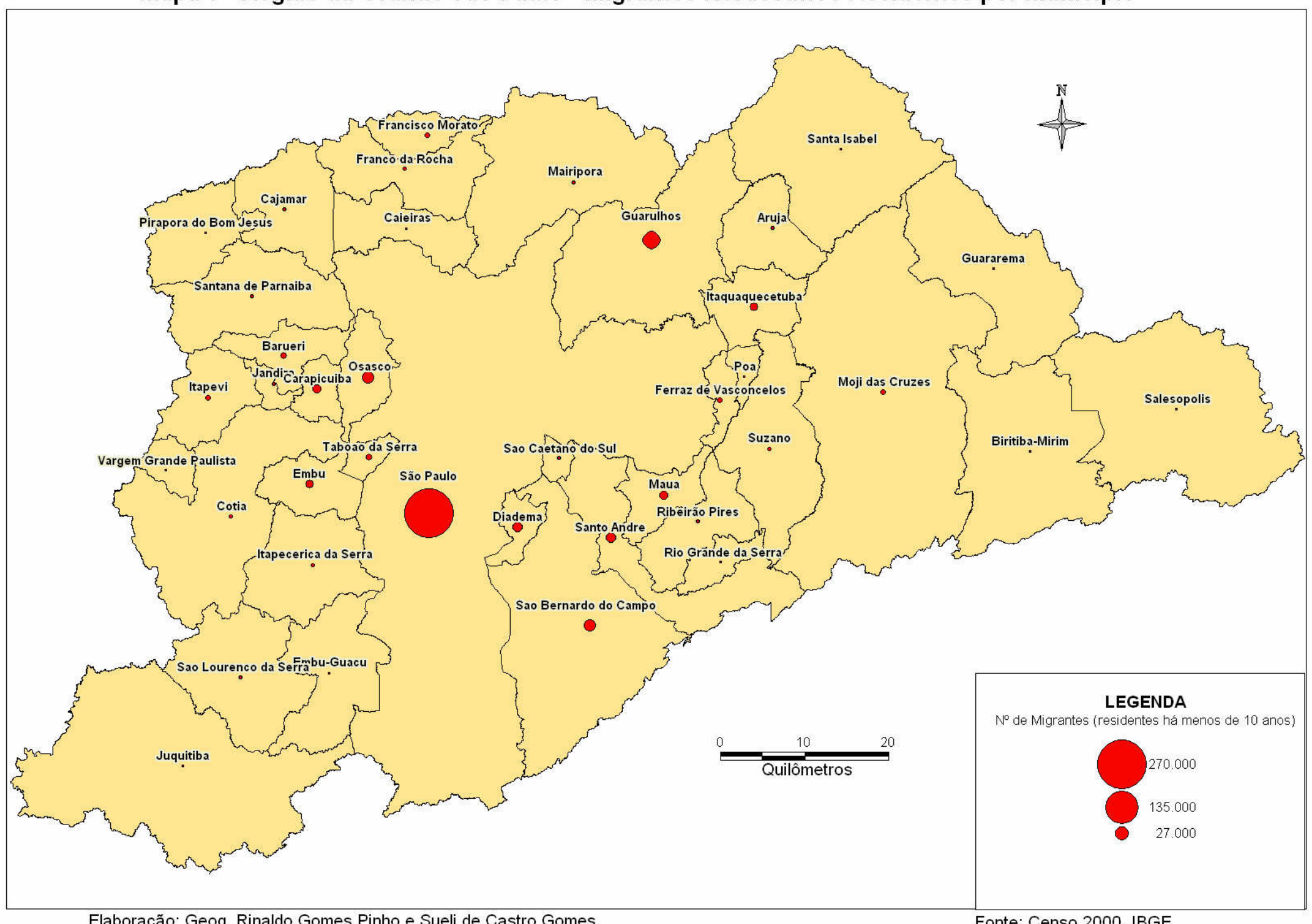

Fonte: Censo 2000, IBGE 
O primeiro mapa "Região da Grande São Paulo - participação dos Nordestinos na População Total por Município" (mapa $\mathrm{n}^{\circ}$ 2) mostra a participação dos nordestinos na população total da Região da Grande São Paulo. ${ }^{53}$ O resultado destacou São Lourenço da Serra como um município em que a população nordestina representa $14 \%$ do conjunto de seu número de habitantes, esse dado mostra o município como uma nova área de ocupação, porém a sua população muito menor (12.199 hab.) comparada como de outros municípios, faz com que a participação relativa dos nordestinos ganhe aí um maior destaque, frente aos outros municípios da Metrópole. Mais relevante é constatar taxas de 3,5\% até $5 \%$ de participação em Barueri, Cajamar, Diadema, Embu, Franco da Rocha, Francisco Morato, Guarulhos, Itaquaquecetuba. Esse conjunto de municípios considerados como cidades-dormitório, é também, provido de parques industriais e algumas atividades econômicas, estimulados pelos eixos viários importantes; essas características motivam uma atração maior dos migrantes. Com uma participação entre 2,6\% e 3,5\% estão municípios como São Paulo, Osasco, Carapicuíba, São Bernardo do Campo entre outros, em que apesar dos nordestinos ter em uma participação menor que o segundo grupo de municípios, são números absolutos significativos, que se diluem no conjunto total da população, que é mais numerosa, particularmente na Metrópole de São Paulo.

A leitura do segundo mapa "Região da Grande São Paulo - Migrantes Nordestinos por Município" (mapa $\mathrm{n}^{\circ} .3$ ) revela melhor, as dimensões da representatividade da atual migração de nordestinos para São Paulo. Observamos, que São Paulo continua sendo ainda o maior centro de atração desses migrantes com quase 272 mil ingressantes, número muito maior que os outros municípios que ficam abaixo dos 50 mil migrantes. Segue, três conjuntos de municípios, que tem sua área urbana conurbada ao município de São Paulo onde entraram de 10 a 50 mil nordestinos nestes últimos dez anos. Esses municípios servem como local de residência, as chamadas cidades-dormitório, mas podem ser também, local de trabalho São os seguintes aglomerados de municípios: um grupo corresponde à região do $\mathrm{ABC}$, integrando Santo André, São Bernardo do Campo, Diadema e Mauá seguindo os eixos viários da Rodovia dos Imigrantes e Rodovia Anchieta, em que a partir dos anos 50, serviram para implantação do pólo industrial automobilístico; outro grupo é constituído por Guarulhos e Itaquecetuba, municípios servidos pelos eixos viários da Rodovia Dutra e Rodovia Airton Sena (antiga Rodovia dos Trabalhadores) onde estão instaladas grandes empresas multinacionais de setores diversificados. E por fim, um grupo constituído por Osasco, Carapicuíba e Barueri, servidos pelos eixos viários da Rodovia Raposo Tavares e Rodovia

\footnotetext{
${ }^{53}$ Ver Tabela II, anexo 4
} 
Castelo Branco. O município de Osasco recebeu importantes indústrias multinacionais de ramos diversificados, hoje se transforma em uma cidade de serviços e comércio, enquanto Carapicuíba é, principalmente, uma cidade-dormitório. Barueri está conurbada à área urbana de Carapicuíba. É importante enfatizar que todos esses grupos de municípios estão interligados, também, pelo transporte ferroviário metropolitano, o que possibilita um melhor deslocamento desses migrantes trabalhadores, do local de residência para o trabalho.

Ocorreram algumas alterações no grande fluxo de migrantes nordestinos nas últimas décadas conformes os últimos estudos vêm apontando, e que devemos considerar para entender essas mudanças na mobilidade dos nordestinos, devemos estudar as modificações econômicas e transformações espaciais da Metrópole da Grande São Paulo, assim como em outros territórios.

A pesquisa de Sandra Lencioni (1991) mostra que há uma ampliação da metrópole, que segue em um raio de $150 \mathrm{Km}$ a partir do pólo da capital paulista. As unidades fabris, atraídas por terrenos baratos, favores fiscais, proximidade do mercado consumidor vão se instalar nessa metrópole expandida, provocando uma desconcentração industrial. A autora, apoiada em Negri, mostra como o número de empregos segue essa reestruturação da localização da indústria: no período de 1980 a 1985. O Interior paulista criou cerca de 87, 6 mil novos empregos na indústria, enquanto a metrópole perdeu cerca de 144 mil postos de trabalho.

Além da dispersão industrial, há os avanços tecnológicos, que provocam o chamado desemprego estrutural. O migrante, portanto, possivelmente, está sendo mobilizado por essa reestruturação espacial, haja vista o crescimento acelerado da região de Campinas. $\mathrm{O}$ nordestino continua migrando para a Capital paulista, mas em maior número desloca-se para a metrópole expandida. As pesquisas ${ }^{54}$ apontam o "corredor" do Estado que está se constituindo como uma área de expansão da migração nordestina, "passando o Nordeste a vigorar como a principal procedência dos migrantes interestaduais de Campinas, Jundiaí, Bragança Paulista, Limeira, Piracicaba...". 55

Os números do Pnad de $2004^{56}$ (Pesquisa Nacional por Amostra de Domicilio) apontam um grande fluxo inverso, reforçando a migração de retorno dos nordestinos desde a metrópole. Enquanto que 400 mil pessoas migraram do Nordeste com destino a São Paulo, 457 mil pessoas migraram de São Paulo para o Nordeste. As pesquisas de Herton Ellery de

\footnotetext{
${ }^{54}$ BAENINGER (2000:131). Ver anexo 5 e 6

${ }^{55}$ LENCIONI (1991)

${ }^{56}$ Fonte: Folha de São Paulo, 23 de abril de 2006.
} 
Araújo $^{57}$ do IPEA (Instituto de Pesquisa Econômica Aplicada) mostram o perfil desse migrante que retorna: a maior parte tem menos de 45 anos, uma escolaridade média de 7,1 anos. - "os nordestinos que vivem em São Paulo nos últimos cinco anos enfrentam taxa de desemprego 18,3 \%, praticamente o dobro da média nacional". Enquanto que os residentes no Nordeste procedentes de São Paulo enfrentam uma taxa de desemprego 12,5\%. Os estudos do IPEA ainda mostram como os nordestinos em São Paulo preenchem as vagas com salários baixos, quando empregados. Um terço trabalha na construção civil ou em serviços domésticos e $67 \%$ ganham um salário mínimo. ${ }^{58}$

Pesquisas que mostram a inserção do migrante nordestino na economia informal, que cresce na mesma ordem que segue o avanço do desemprego na Grande São Paulo ${ }^{59}$. Assistimos diariamente o aumento de vendedores ambulantes nos semáforos, nas ruas, nas calçadas, nas portas das casas, com as mais diversas mercadorias.

A recepção aos nordestinos em São Paulo; desde os precursores até os dias atuais, sempre foi carregada de muita discriminação e preconceito, estigmatizando-os como "Baianos" ou "Cabeça Chata". O estudo de Maura Penna (1992) trata da identidade do nordestino em São Paulo e aborda o preconceito que ele enfrenta. A autora faz um levantamento, na imprensa, de diversos artigos e situações, na época em que a paraibana Luísa Erundina venceu as eleições para a Prefeitura da Capital, levantamento que mostra a xenofobia dos paulistanos. ${ }^{60}$

Os migrantes nordestinos aparecem no plano do visível e do invisível, ocupam os poros da metrópole. Eles não estão somente nos espaços de aglutinação, concentração, mas aparecem na forma de trabalho e não trabalho no processo de formação da metrópole.

Nesse contexto da migração de nordestinos para São Paulo, aparece a necessidade do migrante criar novas formas de inclusão na metrópole. Estudamos um dos grupos de nordestinos que se inseriu em uma dessas formas de inclusão: são os carregadores do Terminal da CEAGESP.

\footnotetext{
${ }^{57}$ Fonte: Folha de São Paulo, 23 de abril de 2006

${ }^{58}$ Salário Mínimo: R\$ 350,00 (23.04.2006)

${ }^{59}$ RAMIRES, 2001

${ }^{60}$ Encontra-se o debate sobre a identidade, preconceito e a imagem do nordestino, também, em autores como PÓVOA NETO (1994) e SOBRAL (1993).
} 


\section{FRUTAS, FLORES, VERDURAS E BAIÃO DE DOIS}

\subsection{A CEAGESP: uma história de mobilidade e metamorfose}

A CEAGESP possui um movimento incessante de entrada e saída de toneladas de produtos agrícolas, que servirão, em sua maior parte, para abastecer a metrópole da Grande São Paulo. O Terminal é o terceiro centro de comercialização de perecíveis do mundo e o maior da América Latina, perdendo apenas para os terminais de abastecimento de Paris (Rüngis) e de Nova York. Para tanto, ele ocupa uma área de $700 \mathrm{mil} \mathrm{m}^{2}$ na Vila Leopoldina ${ }^{61}$. Faremos um recuo histórico do processo de formação desse Centro de Abastecimento ${ }^{62}$ para compreender a sua importância enquanto mercado de trabalho.

O Centro de Abastecimento de São Paulo, antes da Vila Leopoldina, estava estabelecido no entorno do Mercado Municipal $^{63}$, na rua Cantareira e Adjacências ${ }^{64}$. Além das enchentes constantes que inviabilizavam a circulação da mercadoria, outros elementos justificaram a mudança do entreposto comercial, tais como problemas com o tráfego de veículos e o excesso de lixo nas ruas do centro. Os congestionamentos e as enchentes elevavam os preços dos produtos.

O crescimento rápido da cidade e o adensamento da região central, na década de 50, desencadearam alguns estudos de planejamento para uma nova área a serviço do abastecimento, como registrou a obra do jornalista e engenheiro agrônomo José Calil. Nesse documento encontramos o relato do projeto de construção da CEASA, na Vila Leopoldina. Sua principal publicação, além de uma série de artigos, foi o "Estudo para a Melhoria das Condições de Abastecimento"65.

\footnotetext{
${ }^{61}$ Endereço Oficial: Av. Dr. Gastão Vidigal,1.946, V. Leopoldina - São Paulo. Nesse terreno, a Companhia possui $271 \mathrm{mil} \mathrm{m}^{2}$ de área construída.

${ }^{62}$ Cf. site da CEAGESP (www.ceagesp.gov.br)

${ }^{63}$ Instalado desde 1933 numa área de $12.600 \mathrm{~m}^{2}$

${ }^{64}$ Ruas adjacentes: Frutas Nacionais: Rua Cantareira, Rua Barão de Duprat, Rua Pagé, Rua Carlos de Souza Nazareth; Banana: confluência das Ruas Barão de Duprat e Rua Cantareira; Verduras: entreposto da Cantareira, Praça Santo Antonio do Mercado Central; Batata, Cebola e Alho: Rua Américo Brasiliense, Rua Mendes Caldeira, rua Santa Rosa; Aves e Ovos: Praça Fernando Costa, Rua 25 de março.(Relatório de 1965)

${ }^{65}$ Cf. Jornal EntrePosto (maio de 2002). Esse documento foi publicado no Governo Lucas Nogueira Garcez (1951 - 53) e pelo Secretário da Agricultura, o deputado João Pacheco Chaves. Participaram desse estudo o engenheiro agrônomo José Calil, na condição de coordenador geral e os especialistas do quadro técnico da Secretaria da Agricultura e o Prof. André Toselo da Universidade de São Paulo.

CEREAIS: Engenheiro Agrônomo André Toselo (USP/ESALQ), responsável pelos silos e armazéns; FRUTAS, HORTALIÇAS, BATATA, CEBOLA, SUPRIMENTO DE FORRAGENS: José Calil; CARNE BOVINA: médico-veterinário J. Barison-Vilares (diretor Geral de Produção Animal); LEITE E LATÍCINIOS: médico-veterinário Fidelis Alves Neto;
} 
Em 1953, esses estudos foram encaminhados para o então Governador Lucas Nogueira Garcez, que baixou um decreto lei declarando de utilidade pública a área de $700 \mathrm{mil} \mathrm{m.}{ }^{2}$, previamente delimitada, entre o Rio Pinheiros, Loteamento Mofarrej e a Avenida Jaguaré ${ }^{66}$, para a construção da CEASA/SP. O terreno escolhido era uma área de várzea, próxima da ponte do Jaguaré sobre o Rio Pinheiro. Essa área pertencia aos irmãos Mofarrej, Nacib e Hassib. Apesar da distância de 10 quilômetros do centro, apresentava boas condições topográficas, era servida pela ferrovia e possuía bons acessos rodoviários. Assim, essa área foi declarada de utilidade pública para fins de desapropriação.

O planejamento da construção do Terminal de Abastecimento incluía também outros projetos anexos, como o Serviço de Fomento Agropecuário da Capital, a Sede do Cinturão Verde; a Fábrica de Rações e Viveiros de Mudas; o Posto de Mecanização Agrícola; a Central de Incubação e a Usina para desidratação e aproveitamento de resíduos; a construção da área da administração do "complexo" de abastecimento, com bancos, lojas para o comércio local; serviços acessórios, como estação "geradora de força", postos de combustíveis, instalações sanitárias, entre outros. Muitos desses projetos acabaram ficando apenas no papel e não foram implementados.

Apesar do governador Carvalho Pinto $\left(1959\right.$ - 1962) ${ }^{67}$ assumir a construção do CEASA na Vila Leopoldina ${ }^{68}$ juntamente com a construção de silos e armazéns do Estado, quem inaugurou a obra foi o governador Adhemar de Barros. Em 1966, uma enchente inundou o Mercado Central e a Zona Cerealista da Cantareira, fato que levou a uma transferência, por decreto do dia 14 de março desse ano, para a atual Vila Leopoldina. O projeto estava, ainda, incompleto, e muitos comerciantes resistiram em trabalhar no que na época chamavam de "mar de concreto armado". Erguido nos anos 60, o Terminal possuía uma área 17 vezes maior que a do antigo Entreposto. O motorista Joaquim Marques da Silva narrando a sua viagem para o Entreposto, com seu caminhão Ford F 600, no ano de sua inauguração, comenta “Tem a cara da capital, Brasília!". Essa expressão representa bem a

PESCADO: médico-veterinário Emílio Varoli;

AVES E OVOS: médico-veterinário Henrique F. Ramos;

ECONOMIA RURAL: Eng. Agrônomo Diretor do Inst. Econômico Rural;

PROJETOS E PLANTAS: Eng. José Del Nero e Dante Albuquerque Departamento de Mecanização.

${ }^{66}$ Atual Avenida Queiroz Filho.

${ }^{67}$ Lei promulgada 5.444 de 17.11.59, chamado plano de ação do Governo Carvalho Pinto. Ele cria comissão para estudar e propor ao governo do Estado as medidas necessárias à constituição de uma sociedade por ações, sob a denominação de Centro Estadual de Abastecimento S.A., no dia 02 de fevereiro de 1960, resolução $\mathrm{n}^{\circ} 1.170$, dois dias após o diário oficial publica a concessão do crédito concedido pela Secretaria da Agricultura, no valor de Cr\$ 125 milhões para iniciar o projeto. Os recursos financeiros, na ordem de 1 bilhão e 600 milhões de cruzeiros, foram mobilizados pelo BNDES, CREAT, Banco Nacional de Crédito Cooperativo e o Governo de Juscelino Kubitschek. Na época, a área construída era da ordem de 350 mil metros quadrados, mas ela foi substancialmente ampliada com o acréscimo de outras obras necessárias.

${ }^{68}$ Documentos da época se referem à atual área como Jaguaré. 
concepção da arquitetura daquele período, que trazia nos traçados a representação da modernização.

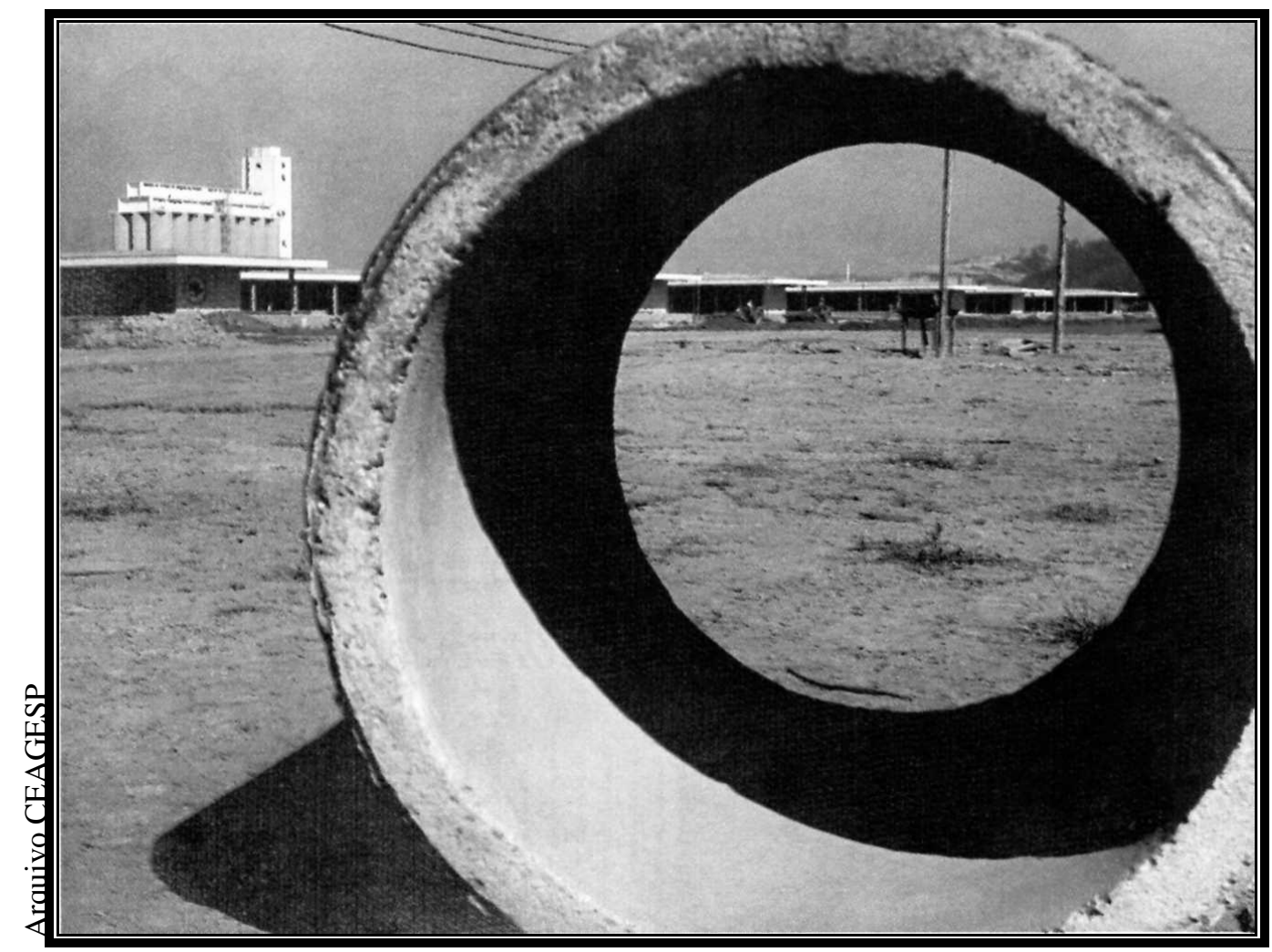

Foto 8: A construção do Entreposto sob o comando do CEASA na Vila Leopoldina.

As pesquisas encontradas nas áreas de geografia e economia, vinculadas às temáticas em torno da CEAGESP, sempre tiveram como preocupação central o abastecimento. Nos anos 60 e início da década de 70, o Instituto de Geografia desenvolveu pesquisas sobre o "Abastecimento em gêneros alimentícios da cidade de São Paulo"69. Dessas pesquisas resultaram vários artigos publicados, como o de Adilson Avanci Abreu (1966), que discutia a ocupação em torno do Mercado Central; de Manoel Seabra (1966), sobre o plano de coleta de dados para essa pesquisa; de Judith de La Corte (1971 e 1978), que estudou alguns aspectos do abastecimento da uva, do figo e do tomate na cidade São Paulo, e por fim, a pesquisa de Rosa Ester Rossini (1971), que estudou o abastecimento de alface na capital. Nessas pesquisas

\footnotetext{
${ }^{69}$ Essas pesquisas iniciaram-se em abril de 1964, quando o Entreposto funcionava na área central da cidade de São Paulo. Os pesquisadores acompanharam as instalações do CEASA, atual CEAGESP, para a Vila Leopoldina, na época chamada de Jaguaré - "(...o que na verdade já estava previsto para mais cedo ou mais tarde) com o apressamento da mudança do Entreposto Municipal de Gêneros Alimentícios e outros setores do Abastecimento (pescado, flores, etc.) para as instalações do Ceasa no bairro do Jaguaré, o que se verificou em janeiro do ano de 1965" (SEABRA, 1966:3).
} 
encontramos referências à mudança do Entreposto do centro da cidade para uma área mais periférica, naquele período.

A época de menores remessas, janeiro e fevereiro, vincula-se ao excesso de chuvas que prejudica não apenas as culturas mas também a comercialização, pois como dissemos chegava a criar sérios problemas junto à Zona Central do mercado devido ao extravasamento do Rio Tamanduateí. (ROSSINI,1971:15).

Essas pesquisas fazem referência às diferenças entre os entrepostos; a CEASA, na Vila Leopoldina, trazia elementos da modernização no setor de abastecimento e era muito mais amplo que o antigo Entreposto Municipal de Produtos Hortifrutigranjeiros da Prefeitura, estimulando o aumento dos volumes de mercadorias que circulam no entreposto da cidade.

A CEASA entrou para a história do abastecimento porque centralizava a comercialização de hortifrutigranjeiros de parte do País. Exceto Pernambuco, nenhum Estado possuía algo igual ao CEASA. As centrais da antiga Guanabara e do Rio Grande do Sul estavam em licitação.

No início, eram poucos agricultores e permissionários, e as instalações eram péssimas. Os trabalhadores enfrentavam os mosquitos, a lama e o descrédito da maioria, que não acreditava no empreendimento. Não havia energia elétrica e a comercialização era iluminada por lampião a gás. Quando perguntamos a um carregador do Mercado Municipal por que ele não foi trabalhar na nova área destinada ao CEASA, ele recordou que era uma área muito fria, e esse foi o argumento para continuar na região central. Só existia uma linha de ônibus, apelidada de "cai duro". Carro de passeio não entrava no Entreposto, por causa da lama e do barro. A maioria dos compradores utilizava carroças como meio de transporte. O portão principal, e único naquele período, era o portão 5. O endereço era rua Froben, sem número, pois não existia a atual avenida Dr. Gastão Vidigal e nem a avenida Marginal Pinheiros. Entretanto, esse local atraiu uma enorme quantidade de trabalhadores que se inseriram de diferentes formas na circulação da mercadoria- alimento. $O$ primeiro presidente da companhia, David Maluf, denomina aqueles tempos heróicos de "Uma festa do trabalho", trazendo uma visão ufanista de sua época, em que o debate da exploração do trabalho era abafado pela Ditadura Militar.

Assim relatam os primeiros atacadistas permisssionários ${ }^{70}$, um grupo de migrantes portugueses, que atuam até hoje. Vejamos a fala de Manuel dos Santos Ochôa que atua no Mercado Livre do Produtor Ele iniciou suas atividades em 14 de março de 1966 - "Isto aqui

\footnotetext{
${ }^{70}$ Entrevistas realizadas por Paulo Fernando Costa do Jornal Elo, março de 2002
} 
era um deserto com chácaras, bois, cavalos, galinhas, etc. [...] Nos primeiros dias ficamos no pavilhão onde está a abóbora".

Sr. Antônio Joaquim Cabecinho, permissionário do Mercado Livre do Produtor, outro migrante português mobilizado para Vila Leopoldina, recorda:

Era muito bom. Lembro-me que eu e os demais que aqui estavam jogávamos malha no MLP. No inverno, acendíamos uma fogueira e ficávamos contando histórias. O pessoal era muito unido. [...] Naquela época, o presidente do CEASA cumprimentava permissionário por permissionário, todas as sextas -feiras.

Outro depoimento:

Aqui era só mato... vim para o CEASA na "marra" [...] Forneciam gelo gratuitamente e ainda não cobravam o aluguel. (Luigi Vennneri, 72 anos, setor de pescados).

Migrante de origem japonesa, Sr. Tadashi Yamashita, mobilizado para o Entreposto, lembrava de suas inquietações: "Brejo! Como é que isso aqui vai encher de gente?”.

Outro depoimento:

Não havia energia elétrica nem restaurante para nos alimentarmos. Enfrentávamos problemas com o transporte para escoar novas mercadorias, a Av. Dr. Gastão Vidigal não existia. Depois surgiu o Restaurante Ceasa (do seu Michel) com a tradicional sopa. (Mário Benassi, atacadista do setor das frutas).

Nos anos 70, o Entreposto, ganha um papel de ponto turístico, nas madrugadas paulistanas, com a famosa sopa de cebola. ${ }^{71}$ A história da sopa de cebola possui duas versões. A primeira se inicia nos anos 60, durante a construção do Entreposto. A diretoria do antigo CEASA convida o português Gouveia, proprietário de boteco da região, para preparar as refeições dos peões-da-obra. Nasce, então o restaurante do Gouveia. Lá era servido, por sugestão do filho do proprietário, Sidônio Gouveia, um caldo "estupidamente" quente e gratinado, que servia para espantar a umidade oriunda do brejo do Jaguaré. A segunda referência é a famosa Sopa de Cebola que teve sua origem no Mercado de Paris, "Les Halles" ${ }^{72}$. Essa tradição foi trazida para o CEASA, no Brasil ${ }^{73}$. Na avaliação do

\footnotetext{
${ }^{71}$ Em 2000, o restaurante CEASA, tenta recuperar o "glamour dos anos 70, da sopa de cebola", no início foram muitas pessoas saudosistas prestigiar - '...à cada 30 pessoas que vem degustar, 18 são de fora'. Em 2006, aconteceu o evento - Virada no Mercado (ver folder anexo 7), onde serviram a sopa para comemorar os 40 anos do Terminal.

${ }^{72}$ O filme "Irma la Dulce", 1963, dirigido por Billy Wilder, tem como cenário o antigo Mercado de Paris e registra toda a dinâmica de seu entorno, inclusive os restaurantes que serviam a sopa.

${ }^{73}$ Fonte: Registro do folder adquirido na Festa dos 40 anos da CEAGESP, no dia 20 de outubro de 2006 e BRENNAN (2004) - anexo.
} 
permissionário Luigi Venneri, do setor de Pescado, a famosa sopa de cebola atraía o consumidor do varejo e ampliava os rendimentos e a comercialização das mercadorias em geral, considerando que os horários de atividade do varejo e atacado eram diferentes dos atuais.

No início só funcionavam os Pavilhões do Armazém dos Produtores (AP's), local em que hoje se comercializa a abóbora, e a Praça do Abacaxi. Em 1976, concluem-se os pavilhões Hortifrutícolas e o pavilhão especializado em frutas (MFE-B), local que foi um campo de futebol. As frutas eram comercializadas onde funciona o atual setor de legumes. Em 1979, termina a duplicação do Pavilhão do Mercado Livre do Produtor. As edificações foram, ao longo dos anos, tomando todos os espaços disponíveis do terreno, seguindo a lógica da racionalidade que a mercadoria impõe, e os espaços em que se jogava bocha, fazia-se fogueira e se conversa em torno e os campos de futebol foram desaparecendo. Esses elementos revelavam os aspectos lúdicos da vida do Entreposto. ${ }^{74}$ Além das mudanças na organização do espaço físico interno do Entreposto, haviam metamorfoses nas esferas administrativas e da vida, modificando o cotidiano dos trabalhadores. Até os horários de funcionamento da Companhia seguiam a lógica da racionalidade, modificando e regulando a vida de seus trabalhadores. Desse modo, o tempo do comércio foi alterado ao longo dos anos, acompanhando a dinâmica da circulação da mercadoria e da metrópole.

\footnotetext{
${ }^{74}$ SEABRA, Odette (2000).
} 
Tab. 4: Resumo dos horários de comercialização praticados no ETSP de 1966 a 2006

\begin{tabular}{|c|c|c|c|c|}
\hline Ano/setor & HF'S & MFE'S & AP'S & MLP \\
\hline $03 / 1966$ & 00:00 às 05:00 & 00:00 às 05:00 & 00:00 às 05:00 & 00:00 às 05:00 \\
\hline $08 / 1971$ & 18:00 às 06:00 & 18:00 às 06:00 & 18:00 às 06:00 & 18:00 às 06:00 \\
\hline $11 / 1974$ & 12:00 às 05:00 & 12:00 às 05:00 & 19:30 às 05:00 & 19:30 às 05:00 \\
\hline $07 / 1976$ & $12: 00$ às $02: 00$ & 12:00 às 02:00 & 20:00 às 02:00 & 20:00 às 02:00 \\
\hline $07 / 1981$ & 13:00 às 24:00 & 13:00 às 24:00 & 19:00 às 01:00 & 19:00 às 01:00 \\
\hline $02 / 1983$ & 12:00 às 23:00 & 12:00 às 23:00 & 19:00 às 01:00 & 19:00 às 01:00 \\
\hline $12 / 1989$ & 08:00 às 20:00 & 12:00 às 20:00 & 17:00 às 23:00 & 17:00 às 23:00 \\
\hline $07 / 1993$ & 08:00 às 18:00 & 08:00 às 18:00 & $15: 00$ às 23:00 & $15: 00$ às 23:00 \\
\hline $07 / 1995$ & 14:00 às 22:00 & 14:00 às 22:00 & 17:00 às 22:00 & 17:00 às 22:00 \\
\hline $12 / 1996$ & 08:00 às 20:00 & 08:00 às 20:00 & $14: 00$ às $21: 00$ & 5:00 às 22:00 \\
\hline $02 / 1997$ & 00:00 às 06:00 & 00:00 às 06:00 & 00:00 às 06:00 & 00:00 às 06:00 \\
\hline 02/1997 & 14:00 às 22:00 & 14:00 às 22:00 & $14: 00$ às 22:00 & 15:00 às 22:00 \\
\hline $04 / 1997$ & 10:00 às 18:00 & 10:00 às 18:00 & 14:00 às 21:00 & 15:00 às 22:00 \\
\hline $05 / 2001$ & 08:00 às 17:00 & 08:00 às 17:00 & 08:00 às 17:00 & $\begin{array}{l}08: 00 \text { às } 17: 00 \\
\left.12: 00 \text { às } 17: 00 \text { ( } 6^{\mathrm{a}} \mathrm{f} .\right)\end{array}$ \\
\hline $07 / 2001$ & 07:00 às 18:00 & 07:00 às 18:00 & 08:00 às 17:00 & $\begin{array}{l}08: 00 \text { às } 18: 00 \\
\left.12: 30 \text { às } 18: 00 \text { ( } 6^{a} \mathrm{f} .\right)\end{array}$ \\
\hline $10 / 2005$ & 06:00 às 20:00 & 06:00 às 21:00 & 08:00 às 21:00 & $\begin{array}{l}08: 00 \text { às } 21: 00 \\
\left.12: 30 \text { às } 22: 00 \text { ( } 6^{\mathrm{a}} \mathrm{f} .\right)\end{array}$ \\
\hline
\end{tabular}

Fonte: Jornal Entreposto, março de 2006.

Esse fato comandava as jornadas de trabalho no entreposto, modificando as rotinas de seus trabalhadores.Desse modo, o Terminal absorvia os atacadistas, carregadores, e outras formas de trabalho do circuito da mercadoria-alimentos, atraindo muitos migrantes ${ }^{75}$ e seus descendentes mobilizados para essa nova organização no setor de abastecimento de alimentos.

O taxista Evaristo Oliveira da Silva, 69 anos, nasceu em Maranguape, no Ceará chegou em São Paulo no dia 06 de fevereiro de 1940. Sua história de vida está vinculada ao Entreposto. Veja o seu depoimento:

O Mercadão encheu e eu fui para o Campo de Marte com os permisssionários de lá. Depois, o Campo de Marte também encheu e a gente foi para o Pacaembu [Praça Charles Muller], que também encheu. Depois disso tudo, eu vim para cá junto com os 'meninos' [permisssionários]. Não tinha nem lugar para comer aqui. A gente comia no 'cai duro', um barracão de madeira que ficava onde é o posto de gasolina BR [portão cinco]. Tinha muita fila para comer prato feito de lá. Onde fica aquele posto Esso na [avenida Dr.] Gastão Vidigal era uma cocheira das vacas criadas na região. Naquele tempo, a gente chegava às 7 horas com um copo na mão, retirava o Leite das vacas e bebia na hora ${ }^{76}$.

\footnotetext{
${ }^{75}$ Encontramos um número expressivo de descendentes de japoneses no Terminal, além dos próprios imigrantes. Além da colônia, destacamos, também os portugueses, e mais especificamente no comércio das flores, pode-se encontrar holandeses e seus descendentes, migração externa, mais recente.

${ }^{76}$ Entrevista concedida a Paulo Fernando Costa, jornalista do EntrePosto (março de 2005).
} 
Ele continua seu relato, no qual permite explicitar a dinâmica daquele período em relação aos horários e aos vínculos com outros espaços da cidade:

Só a noite. Aqui começava às 7 horas da noite e terminava às 5 horas da manhã. À tarde, eu ia para [o largo] Concórdia, no Brás para puxar a lotação da turma de lá para cá...permissionário, carregador, todo mundo. Era DKW [decavê], era esse carro aí que você nem sabe como ele é. Eu trazia o pessoal de lá e descarregava no Restaurante Ceasa. (Evaristo, março de 2005).

A CEAGESP (Companhia de Entrepostos e Armazéns Gerais de São Paulo) surgiu como locadora de espaços para a comercialização e armazenagem de produtos agrícolas. Nasceu da fusão do CEASA (Centro Estadual de Abastecimento S.A.) e da CAGESP (Companhia de Armazéns Gerais do Estado de São Paulo), que atuavam nessas frentes relacionadas à Agricultura. A criação da CEAGESP aconteceu quando o Entreposto São Paulo funcionava há três anos, em 31 de maio de 1969. Na época, o Estado de São Paulo tinha 18 milhões de habitantes, menos da metade dos atuais 37 milhões e a Grande São Paulo apresentava 7.863.534 habitantes. As feiras livres eram a principal forma de abastecimento da população. Vejamos o volume comercializado naquele período:

\section{Tab 5:}

\begin{tabular}{||c|c||}
\hline \multicolumn{2}{|c|}{$\begin{array}{c}\text { Quantidades anuais dos produtos } \\
\text { hortifrutigranjeiros e pescados no ETSP }\end{array}$} \\
\hline \hline Ano & Toneladas \\
\hline \hline 1968 & 1.107 .185 \\
\hline \hline 1969 & 1.099 .818 \\
\hline 1970 & 1.257 .378 \\
\hline
\end{tabular}

Fonte: Relatório da Diretoria - CEAGESP (1970).

Quando o Ceasa deu lugar à CEAGESP, o entreposto já centralizava o abastecimento de parte do país. Até o comércio de flores foi levado da praça Charles Müller no bairro do Pacaembu para o Entreposto de São Paulo, em 1967. Naquela época, a feira funcionava, das 11:00 às 16:00 horas de $3^{\mathrm{a}}$ e $6^{\mathrm{a}}$ feira ${ }^{77}$.

\footnotetext{
${ }^{77}$ Fonte: Jornal CEAGENTE, setembro de 1976 - ano I, no 2. Jornal Oficial da Empresa, Presidente José Henrique Turner.
} 
Em 1977, quando o Pavilhão Livre do Produtor foi duplicado, a CEAGESP bateu um recorde: comercializou 6,2 mil toneladas de produtos num dia, superando o maior mercado do mundo, o Paris - Rüngis, na França.

Em 1997 o controle da CEAGESP foi transferido para a União, subordinado ao Ministério da Agricultura, Pecuária e Abastecimento. O Estado de São Paulo, na Gestão Mário Covas ${ }^{78}$, procurando amortizar parte de suas dívidas junto ao Governo Federal, repassou a Companhia como uma forma de pagamento.

Em 2001 cogitou-se a mudança da CEAGESP para uma área próxima do Rodoanel, entre as Rodovias Raposo Tavares e Régis Bittencourt. Esse projeto partiu da Secretaria Estadual de Agricultura e Abastecimento, assumida pelo Secretário João Carlos de Souza Meirelles, na gestão Geraldo Alckmin. Era um projeto de privatização da CEAGESP, assumido pelo Ministério da Agricultura. À frente dos governos estadual e federal estava o mesmo grupo político ${ }^{79}$, o que possibilitava tal encaminhamento. Um dos argumentos mais fortes para a transferência da CEAGESP da Vila Leopoldina foi o congestionamento, principalmente nos horários de pico, sobretudo na sexta-feira, ocasionado pelos 17.500 veículos, dos quais 10 mil são caminhões que trafegam nessas áreas, atraídos pelo Entreposto. Outro ponto de congestionamento é o centro da cidade, onde circulam 5 mil veículos, na atual Zona Cerealista da Rua Santa Rosa. Vejamos o que dizia o Secretário Estadual da Agricultura:

As atuais instalações estão no seu limite. O local está ultrapassado porque não há logística para o transporte. Foi projetado nos anos 60 . A central não suporta mais o trânsito da região... É necessário um local que tenha pontos de eletricidade para abastecer caminhões refrigerados. O espaço físico do mercado foi programado para receber caminhões pequenos, não carretas. (João Carlos Meireles, F.S.P, 18.11.2001).

Nesse mesmo período, inicia-se uma intensa verticalização da Vila Leopoldina. As rápidas transformações urbanas pressionam a Prefeitura de São Paulo, que encaminha à Câmara de Vereadores o Plano Diretor Estratégico do Município e um Plano de Operação Urbana para a Vila Leopoldina, desenvolvidos pela Secretaria Municipal de Planejamento (Sempla), com o propósito de atrair investimentos, serviços, comércio e escolas.

O projeto da transferência da CEAGESP e a saída das várias indústrias da Vila Leopoldina, ia ao encontro de um projeto de reurbanização, pretendido pelo município e Estado. A pesquisa de Silva (2006) que estuda essa relação institucional, e também o modo

\footnotetext{
${ }^{78} \mathrm{Na}$ gestão do Governador Mario Covas, a CEAGESP foi a leilão duas vezes, porém não houve nenhum interessado na proposta, segundo depoimento do Jornalista Paulo Fernando Costa do Jornal Entreposto.

${ }^{79}$ PSDB (Partido da Social Democracia Brasileira).
} 
como as operações urbanas tratam os espaços como negócio, atraindo "as contrapartidas" com os empreendimentos, constata essa relação na Operação Urbana Vila Leopoldina, quando estuda a urbanização da Favela Nova Jaguaré.

Os galpões das fábricas, vazios, estão sendo ocupados aos poucos por lojas, academias, concessionárias de carros, e principalmente, estão dando lugar a edifícios de alto padrão imobiliário. O projeto estimulou a especulação imobiliária, pois a ventilação da notícia atraiu novos investimentos para a região, que se configura como uma extensão das áreas nobres adjacentes ,como a City Lapa, o Alto da Lapa e o Alto de Pinheiros.

O preço médio do metro quadrado na Vila Leopoldina varia de $\mathrm{R} \$ 300,00$ a $\mathrm{R} \$ 400,00$, enquanto que nos eixos viários, como a Av. Doutor Gastão Vidigal e Imperatriz Leopoldina, o preço se eleva de $\mathrm{R} \$ 600,00$ até $\mathrm{R} \$ 1.000,00$ o metro quadrado (18.11.2001 - Estado de São Paulo).

A imprensa trazia a informação da mudança como algo dado:

- "Muda o Cenário na Vila Leopoldina.” (Estado de São Paulo.18.11.2001).

- "Ceagesp vai para o rodoanel até o fim de 2003." (Estado de São Paulo. 18.11.2001).

- " "Entalado, Ceagesp pode ir para o Rodoanel.” (Folha de São Paulo. 18.11.2001).

- "Ceasa deixa cidade em busca de eficiência.” (Folha de São Paulo. 31.03.2001).

- "Mudança da CEAGESP para Rodoanel abre espaço para um novo bairro de alto padrão na Vila Leopoldina.” (Revista Exame, setembro de 2001).

- "Esta área será da FAPESP." (Jornal da Gente, 15.06.2002).

Vejamos parte de um artigo da imprensa escrita sobre esse fato - “... segundo o engenheiro Henrique Peters Jr., a saída do Ceagesp (sic) para a região do Rodoanel é esperada, pelo mercado imobiliário, para o próximo ano.” (Folha de São Paulo. 14.02.2002).

O artigo de Gedanken (2001), na revista EXAME, exalta as potencialidades da área, por sua excelente localização, como um novo pólo aglutinador, para moradores tanto de Alphaville quanto do Alto de Pinheiros e do Alto da Lapa. A revista encomendou um estudo sobre as novas formas de ocupação da atual área da CEAGESP, a partir dos padrões de uso e ocupação do solo da Avenida Luiz Carlos Berrini. Para o terreno vizinho à CEAGESP, de 32 mil $\mathrm{m}^{2}$, já existe um projeto denominado Gold Center, caracterizado como um complexo empresarial e cultural para o qual um grupo de empresários destinou $\mathrm{R} \$ 150$ milhões para a sua construção. Esse empreendimento é coordenado pela IBGM (Instituto Brasileiro de Gemas e Metais Preciosos) e CGN (Galli Construtora e Incorporadora). Vejamos o 
depoimento do coordenador da Operação Urbana Vila Leopoldina, Marcelo Bernadini, em entrevista realizada por Flávia Elaine da Silva (2006: 17):

... o que impulsionou esta operação foi o anúncio de Fernando Henrique dizendo que ia doar a CEAGESP para a FAPESP. Aí, criou-se a possibilidade, a iminência, de você ter uma área de 900.000 metros quadrados que iam despencar no mercado, da noite para o dia, sem o menor controle. Eu acho que o mercado também entendeu o recado, e saiu correndo atrás. A área é também localizada, próxima ao alto da Lapa, é 'boca de estrada', mas tem acessos ao centro.[...]

A autora se utiliza desse depoimento para analisar o processo de valorização da área, através da aquisição de grandes lotes da Vila Leopoldina pelas incorporadoras e construtoras. Assim, vemos o 'jogo' do mercado imobiliário, enquanto se especulava a saída da CEAGESP da Vila Leopoldina.

Em maio de 2001 o Conselho Nacional de Desestatização, órgão interministerial do governo Federal, já havia dado o seu aval. Duas empresas coordenadas pelo BNDES (Banco Nacional de Desenvolvimento Econômico e Social) estavam fazendo uma avaliação da companhia para poder efetuar a venda. A empresa Desenvolvimento e Planejamento Ltda. era a consultora responsável pela avaliação econômica - financeira; o HSBC, além de fazer a avaliação econômica, faria a proposta de venda e definiria o valor. Toda a proposta estava tão certa para a gestão de Fernando Henrique Cardoso, que durante a festa de 40 anos da Fundação de Amparo à Pesquisa do Estado de São Paulo - FAPESP, que ocorreu em junho de 2002, ele anunciou a doação da área da CEAGESP para a instituição.

O projeto inclusive alterava o nome de CEAGESP para CIAP - Central Integrada de Abastecimento de São Paulo ${ }^{80}$ ou CIASP (Centro Integrado de Abastecimento de São Paulo $)^{81}$. Segundo o Secretário da Agricultura, J.C. Meirelles, já havia uma nova área de mais 1 milhão de metros quadrados no Rodoanel Mário Covas ${ }^{82}$. O CIAP reuniria os permissionários e empresários cerealistas em uma Sociedade de Propósitos Específicos (SPE). A concepção neoliberal chegava às filigranas do abastecimento, no qual o Estado teria uma participação mínima. Ele entraria com o terreno e o projeto.

A idealização de modernização da CEAGESP aparece em razão de indicadores da obsolescência, declínio e diminuição do comércio. O projeto contemplava a instalação de fibra ótica para permitir o comércio de flores, verduras e cereais pela Internet $\mathrm{O}$ comércio

\footnotetext{
${ }^{80}$ Fonte: Estado de São Paulo 18.11.2001.

${ }^{81}$ Fonte: Folha de São Paulo 31.03.2002

${ }^{82}$ Anel Viário de $170 \mathrm{Km}$ que circundará a capital paulista (.Cf. VEJA, 23 de outubro,2002). A área destinada à nova CEAGESP localiza-se no trecho entre as rodovias Régis Bittencourt e Raposo Tavares. O jornal Estado de São Paulo afirma que a área tem 1 milhão $\mathrm{m}^{2}$. A Folha de São Paulo registra 1,5 milhão de $\mathrm{m}^{2}$, dos quais de 800 a 900 mil m. ${ }^{2}$ deveriam ser ocupados.
} 
eletrônico evitaria viagens desnecessárias até a Central da CEAGESP, melhorando a qualidade dos produtos e diminuindo o desperdício. O custo do projeto foi estimado em $\mathrm{R} \$$ 300 milhões, e previa que até 2004 a obra estaria concluída. Fazia estimativas que o movimento anual ampliaria de 3,6 milhões (CEAGESP e Zona Cerealistas) para 5,4 milhões de toneladas.

Nesse projeto os permissionários deixariam de ser locatários e passariam a ser proprietários, sócios da nova central. Aquele que não tivesse recursos faria um financiamento junto ao BNDES - Banco Nacional de Desenvolvimento Econômico e Social. Para esse processo ocorreria uma licitação pública. A idéia era viabilizar o novo centro de abastecimento para desativar o atual. As entidades sindicais e associações representativas não foram consultadas nesse processo e se posicionaram contra a proposta, do modo como foi conduzida.

No fim de 2002, o PSDB - Partido da Social Democracia Brasileira - perdeu as eleições, no pleito presidencial para o PT - Partido dos Trabalhadores - e, em 2003, Luiz Inácio Lula da Silva assumiu o Governo Federal. A mudança de gestão reorientou a gestão da CEAGESP e a possibilidade de sua transferência, ou seja, de sua privatização, foi engavetada, apesar de estar no plano de desestatização do BNDES. Buscou-se aumentar o volume financeiro da Companhia ${ }^{83}$ e outras formas de modernização da CEAGESP foram propostas pelo novo governo.

A gestão do Governo de Luiz Inácio Lula da Silva (2003 -2006) reorienta as ações da CEAGESP, ressaltando o papel social deste Centro de Abastecimento. A Companhia se insere no mais importante programa de Governo dessa gestão - o Programa Fome Zero - sobretudo na implementação de algumas políticas estruturais: geração de emprego e renda, incentivo à agricultura familiar e combate ao desperdício. Essa última ação ocorre através da coleta de alimentos destinados a algumas instituições filantrópicas, do reaproveitamento dos alimentos descartáveis ao consumo humano como ração destinada à criação de suínos e da produção de adubo orgânico oriundo dos alimentos descartados. A idéia do reaproveitamento dos alimentos que eram desperdiçados é produzir novas fontes de matérias-primas e gerar novos empregos. Assim, a CEAGESP assume o papel de ser uma referência em reaproveitamento de

\footnotetext{
${ }^{83}$ Até o encerramento desta pesquisa, a CEAGESP continuava no programa de privatização, o Plano Nacional de Desestatização do BNDES. Seu último Presidente Francisco Cajueiro registra em suas entrevistas, favorável a tal programa, diferentemente de seu antecessor Wladimir Pracidelli. As duas direções ocorreram na primeira gestão do Governo Lula, seguindo orientações diferentes, pois ficaram sob o contexto político que o país atravessou nesse período e a política de alianças construída pelo Partido dos Trabalhadores, daí originando diferentes direções da diretoria.
} 
seus resíduos, conforme registramos na entrevista com Luciano Legaspe ${ }^{84}$, geógrafo e responsável pelos Serviços Gerais.

Em 2006, a imprensa escrita publica um artigo, reorientando o discurso em relação ao CEAGESP. Vejamos:

... Morar perto dessa Meca da alimentação é uma vantagem do ponto de vista econômico. Isso porque três vezes por semana acontecem varejões na Ceagesp, onde é possível adquirir produtos que apresentam alta qualidade com preços bem em conta.

Esses varejões movimentam 250 toneladas de produtos por mês, um número que revela que os moradores de bairros próximos - Alto da Lapa, Alto de Pinheiros e a própria Vila Leopoldina - já despertaram para a facilidade... (Folha de São Paulo, 04 de junho de 2006).

$\mathrm{O}$ artigo segue mostrando dados de março de 2006. Nesse período, os produtos desses varejões estão $38 \%$ mais baratos, em média, que nas feiras-livres. Ele se encerra, comunicando que a subprefeitura da Lapa está revitalizando o entorno do local. Vemos aqui que há uma reorientação do discurso. $\mathrm{O}$ que antes era um estorvo para o setor imobiliário, agora, com a política de não transferência do Entreposto, transforma-se em vantagem por se morar próximo do Centro de Abastecimento. Assim, o capital imobiliário sempre busca a sua valorização tornando a CEAGESP da Vila Leopoldina um bem imobiliário.

\footnotetext{
${ }^{84}$ Entrevista realizada em: 16.12 .2003$.
} 


\subsubsection{A organização, o funcionamento e a importância da CEAGESP}

No ano de 2004, a cidade de São Paulo completava 450 anos; e a prefeitura estabeleceu que o tema do Carnaval para o desfile das escolas de samba fosse sobre a cidade. Então, com o tema "Tá na Mesa! Com a CEAGESP a fome é Zero. Devaneio de uma Cidade Abastecida", a escola de samba Acadêmicos do Tucuruvi, de São Paulo, homenageou a CEAGESP, contando a sua história (veja anexo o samba-enredo - $\mathrm{n}^{\circ} 8$ ). Assim, pode-se sentir a importância do Terminal para a cidade de São Paulo. Um equipamento urbano que se destaca na cidade e que acabou sendo escolhido no plano do simbólico para representar o que é São Paulo pelo carnavalesco, naquele ano.

A localização da CEAGESP na Vila Leopoldina (Zona Oeste do Município de São Paulo), entre as Marginais do Rio Pinheiros e Rio Tietê, próxima de rodovias importantes, como a Anhanguera, Bandeirantes, Régis Bittencourt, Raposo Tavares e Castelo Branco, facilita a confluência de caminhões com produtos de diversas partes do país, assim como a circulação de feirantes, quitandeiros e comerciantes dos sacolões. Lembrando que $90 \%$ das mercadorias que chegam no Entreposto são transportadas por caminhões. ${ }^{85}$ Além da estrutura rodoviária, bem próxima à CEAGESP, existe a linha ferroviária da CPTM (Companhia Paulista de Trens Metropolitanos), que possibilita o transporte dos trabalhadores e a circulação de grãos ou outros produtos, para armazenagem ou comercialização.

Entre novembro de 2003 e julho de 2004, pesquisadores do Laboratório de Planejamento e Operação de Transportes do Departamento de Engenharia da Escola Politécnica da USP realizaram um diagnóstico da situação do Entreposto Terminal de São Paulo, CEAGESP, na Vila Leopoldina. O objetivo era desenvolver um Plano Diretor para essa área. Esse trabalho foi realizado pelo Prof. Dr. Nicolau Dionísio Fares Gualda (2004), intitulado "Estudos básicos para a elaboração do Plano Diretor do ETSP". ${ }^{86}$ Esse documento afirma que a localização do Entreposto na Vila Leopoldina é boa por ser um local estratégico. Essa pesquisa originou o estudo de Bianca de Cássia Romero (2006) que abordará o CEAGESP como uma Plataforma Logística, voltada ao transporte, armazenagem e comercialização.

\footnotetext{
${ }^{85}$ Fonte: ROMERO $(2006,58)$.

${ }^{86}$ Houve uma pesquisa de campo realizada em 15/05/2004, em que realizaram 291 entrevistas e a partir daí construíram algumas tabelas como: Veículos de Transporte Utilizados pelos Usuários, Origem das Mercadorias Comercializadas, segundo o Tipo de Carga, Destino das Mercadorias Comercializadas, segundo o tipo de Carga, Destino das Mercadorias Comercializadas, segundo a Natureza do Destinatário, Destino das Mercadorias por região brasileira, metrópole da Grande São Paulo e outros países do Mercosul, destino por estado brasileiro, municípios da metrópole de São Paulo e regiões do Estado, veja no anexo 9 ao 16.
} 
Nas plataformas logísticas européias há uma característica de intermodalidade, ${ }^{87}$ diferente desse Entreposto. Mesmo assim, ele é "um ponto chave da cadeia logística, de onde estão concentradas atividades e funções que agregam valor aos produtos comercializados." (ROMERO,2006: 59-60).

Os estudos de Romero (2006) revelam que $68 \%$ do total comercializado no Terminal chega pelas rodovias Regis Bittencourt, Presidente Castelo Branco, Raposo Tavares, Bandeirantes e Anhanguera. Tais rodovias convergem para a região do Jaguaré e da Vila Leopoldina, onde o Entreposto está localizado, com acesso pela marginal do Rio Pinheiros e Rodoanel "Mário Covas".

Vejamos o mapa de localização da CEAGESP:

${ }^{87}$ Fonte: Romero (2006). 


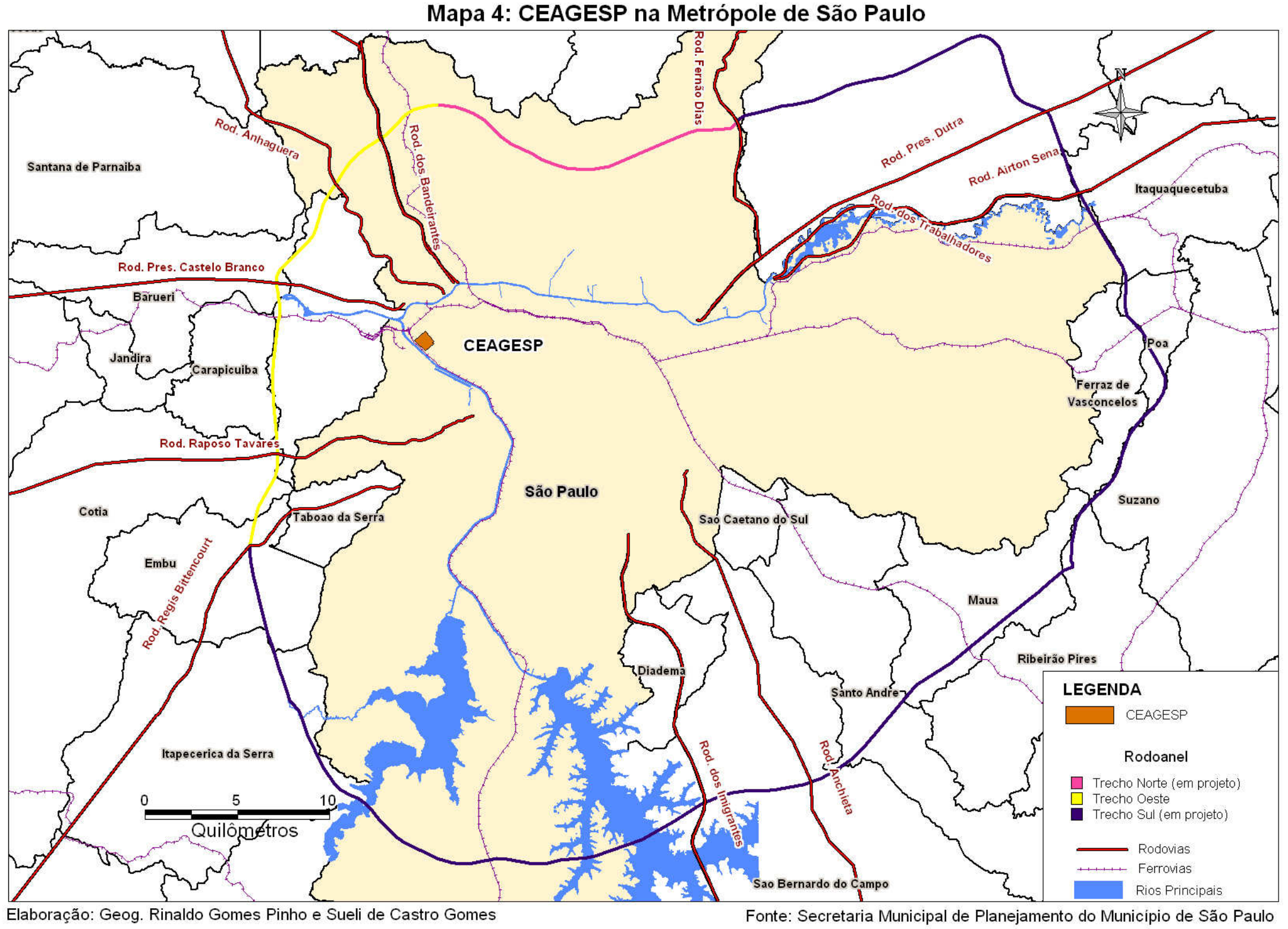


Tab. 6 : Resumo das quantidades e em notas, por via de acesso a São Paulo

\begin{tabular}{|c|c|c|c|c|}
\hline \multirow[b]{2}{*}{ VIA DE ACESSO } & \multicolumn{4}{|c|}{2000} \\
\hline & Quantidade (notas) & $\%($ em notas $)$ & Quantidade (em Kg.) & $\%(\mathrm{em} \mathrm{Kg})$ \\
\hline SP 270 - Raposo Tavares & 216.643 & 26,88 & 405.282 .439 & 15,48 \\
\hline SP 330 - Anhanguera & 136.046 & 16,88 & 703.362 .782 & 26,87 \\
\hline SP 280 - Castello Branco & 113.050 & 14,03 & 229.051 .240 & 8,75 \\
\hline BR 116 (Sul) - Regis Bittencourt & 53.663 & 6,66 & 193.721 .937 & 7,40 \\
\hline SP 066 - (Suzano / Mogi) & 44.332 & 5,50 & 27.295 .131 & 1,04 \\
\hline BR 381 - Fernão Dias & 42.867 & 5,32 & 94.473 .368 & 3,61 \\
\hline SP 348 - Bandeirantes & 25.048 & 3,11 & 39.014 .285 & 1,49 \\
\hline SP 150 - Via Anchieta & 3.760 & 0,47 & 7.751 .938 & 0,30 \\
\hline Transferência & 69.043 & 8,57 & 384.581 .145 & 14,69 \\
\hline São Paulo & 3.340 & 0,41 & 857.872 & 0,03 \\
\hline Totais Analisados & 755.147 & 93,69 & 2.353 .347 .471 & 89,91 \\
\hline TOTAIS MOVIMENTADOS & 805.989 & 100,00 & 2.617 .540 .770 & 100 \\
\hline
\end{tabular}

Fonte: Banco de Dados fornecidos pelo Departamento de Informática da CEAGESP in: ROMERO (2006). 
Aproximadamente $70 \%$ das mercadorias que chegam ao Terminal passam pelos principais eixos rodoviários que cruzam a cidade de São Paulo, conforme observamos no mapa $n^{\circ} 4$ e na tabela $n^{\circ} 6$, assim tornando a acessibilidade um ponto que fortalece a integração do Terminal na Vila Leopoldina.

Atualmente, a Companhia concentra a comercialização, segundo as estimativas, de mais de 10 mil toneladas de alimentos por dia - que abastecem $60 \%$ da Grande São Paulo ${ }^{88}$ e parte do país - além de 30 mil toneladas de flores por ano ${ }^{89}$. Os negócios realizados pelos 3.800 permissionários ${ }^{90}$ somam $\mathrm{R} \$ 9,5$ milhões $/ \mathrm{dia}^{91}$. Diariamente circulam aproximadamente 50 mil pessoas e o movimento de volume comercializado mensal é estimado em 243 mil toneladas. $^{92} \mathrm{O}$ lixo produzido chega a 100 toneladas por dia São resíduos orgânicos gerados pelo Entreposto, o que corresponde a cerca de $1 \%$ do volume de produtos que circulam neste centro de abastecimento. Nesse Entreposto são comercializados os mais diversificados produtos, vindos de 1.475 municípios, de 25 Estados brasileiros e também de outros 11 países: Argentina, Chile, Espanha, China, Portugal, Uruguai, EUA, Itália, França, Peru e Canadá, nesta ordem de importância na participação de volume comercializado."O vai-e-vem de veículos e de pessoas nesta pequena cidade nunca pára e depois da comercialização, os caminhões carregados partem da capital para abastecer a população do interior e de outros Estados." (CEAGESP).

Romero (2006) afirma que através do ETSP comercializa-se $24,56 \%$ de todo volume negociado nas centrais de abastecimento do país. Desde 1999, as mercadorias estocadas na CEAGESP podem ser vendidas através do sistema de Leilão Eletrônico do Banco do Brasil S. A., que está conectado a todas as bolsas de mercadorias existentes no país. A Companhia atua no setor atacadista, e também no varejo. Além do Entreposto da Vila Leopoldina, ela possui 47 unidades varejistas, que comercializam 11 mil toneladas mensais de alimentos, em varejões, comboios e sacolões. Esses são fiscalizados pela Companhia em relação ao preço e qualidade do produto. O valor do varejo não deve ultrapassar $20 \%$ do valor do atacado.

A autora Bianca Romero (2006), estudou as vantagens e desvantagens da implantação de um outro entreposto como o Terminal na cidade de São Paulo. Dois locais foram

\footnotetext{
${ }^{88}$ Informe do site da CEAGESP, acessado em janeiro de 2005.

${ }^{89} \mathrm{O}$ volume de flores comercializado no Entreposto da capital de janeiro a junho de 2006, conforme seção de Economia da CEAGESP é de 14.446 toneladas, média mensal de 2.407 toneladas.

${ }^{90}$ Comerciantes atacadistas, varejistas ou de serviços que tem permissão para trabalhar na Ceagesp, pois alocam uma determinada área do Terminal.

91 Fonte: o dado do site http:// ultimosegundo.ig.com.br (25.05.06) era de R\$ 7 milhões,. Já em setembro de 2006, o setor de comunicação atualizou os dados o para $\mathrm{R} \$ 9,5$ milhões.

${ }^{92}$ Fontes: Folha de São Paulo. 25 de abril 2004 e site da empresa acessado em 12.05.06. O volume mensal é da ordem de 240 mil toneladas. Isso significa um movimento anual de 2880 mil toneladas. Os dados de setembro de 2006, foram fornecidos pelas estimativas da seção de Economia da Administração da CEAGESP.
} 
cogitados: primeiro, um local próximo ao Rodoanel, conforme anteriormente projetado pelo governo Estadual. Segundo, um local na Zona Leste da cidade. Como um número significativo de usuários do terminal é da Zona Leste, abriu-se a possibilidade de projetar um outro entreposto que fosse filial do existente na Vila Leopoldina. A dissertação identifica a especulação imobiliária e a cultura dos permissionários e usuários, refratários às inovações, como ameaça a possibilidade de mudança do local. A poluição causada pelo tráfego de veículos, a baixa eficiência causada pela precariedade nas instalações e os transtornos causados por possíveis reformas seriam pontos desfavoráveis à permanência do entreposto na Vila Leopoldina. No entanto, a manutenção dos clientes atuais, a proximidade dos centros consumidores, a sua acessibilidade e o fato de ser um pólo gerador de empregos são considerados pontos fortes para a sua permanência. Os aspectos favoráveis à sua permanência apontam para as oportunidades do entreposto na Vila Leopoldina como sua modernização, o aumento da capacidade das instalações, criação de novos negócios e um programa de redução de perdas. Quanto à transferência do Entreposto para o Rodoanel, entre as desvantagens citadas na pesquisa, foi citado o impacto social causado por alterações em relação à mão-deobra, entre outros. A pesquisa aponta no sentido de se pensar em uma descentralização, criando outros espaços filiados ao Terminal da Vila Leopoldina, que possui uma situação geográfica de localização privilegiada.

Presente em todo o Estado de São Paulo, a Companhia mantém doze Entrepostos Atacadistas no interior, que descentralizam o abastecimento, além do Entreposto Terminal da capital. São as CEASAs de São Paulo, Ribeirão Preto, Sorocaba, São José do Rio Preto, São José dos Campos, Presidente Prudente, Piracicaba, Araraquara, Bauru, Araçatuba, Franca e Marília, apresentados pela ordem de importância, isto é, volume de produtos comercializados. O Entreposto de Guaratinguetá está subordinado à gerência de São José dos Campos e comercializa apenas flores. A Companhia possui 30 unidades de armazenagem com capacidade de 1,3 milhão de toneladas de produtos. Seus principais clientes são produtores rurais, órgãos governamentais, empresas exportadoras e importadoras, cooperativas, empresas rurais e usinas. A CEAGESP, além de locadora de espaços, também tem programas de capacitação do produtor, classificação e controle de qualidade dos produtos. Para nossa pesquisa nos restringimos a estudar o Terminal da Vila Leopoldina, enquanto mercado de trabalho no qual foram inseridos os migrantes, principalmente os nordestinos.

No ano de 2006, o setor de Controle da Qualidade de Hortifrutigranjeiros (CQH) realizou uma pesquisa com os clientes do Terminal e identificou que os feirantes continuam a ser a maioria dos clientes $(31,55 \%)$, seguidos pelos supermercados $(19,43 \%)$ e distribuidores 
(19,07\%). A Região Metropolitana de São Paulo é destino final da maioria das mercadorias comercializadas $(76,11 \%)$, o restante é comercializado para o Interior $(15,33 \%)$ e outros Estados $(6,24 \%){ }^{93}$

O Terminal completou seus quarenta anos de existência com alguns problemas visíveis e que foram detectados pelo seu Plano Diretor, como a precariedade das instalações físicas, que necessitam de reformas emergenciais; a falta de segurança no espaço interno, exigindo maior controle na circulação de pessoas e veículos; e a ausência de um plano de marketing, visando explorar o potencial mercadológico do Terminal, considerando que nos últimos tempos, a Companhia perdeu muitos clientes, como os grandes supermercados, que montaram plataformas próprias de compras. ${ }^{94}$

\subsubsection{A caracterização da área interna do Terminal na Capital}

O espaço do CEAGESP foi projetado para ser dividido em setores, conforme as características do produto-alimento e de sua comercialização. As edificações são divididas em seis setores (frutas; legumes e abóboras; verduras; batata, cebola e coco), identificadas por um conjunto de letras. Vejamos a seguir:

- Os setores MFE (Mercado de Frutas Estacionais) e HF (Pavilhões de Hortifrutícolas) são responsáveis pelo embalamento e comercialização de frutas;

- O setor MLP ${ }^{95}$, que significa Mercado Livre do Produtor, é o Pavilhão que vende, no atacado e no varejo, flores, verduras e legumes;

- O setor MSC (Mercado de Secos e Cereais) é responsável pelo embalamento e comercialização de verduras;

- Os setores AM e BP é responsável pelo embalamento e comercialização de batatas, cebola e alho;

- Pavilhão PBC (Praça da Batata e Cebola) onde se realiza o varejão, a feira dos automóveis e a venda de flores no atacado;

\footnotetext{
${ }^{93}$ A pesquisa foi realizada com 561 compradores (uma amostra de $30 \%$ do universo total), aplicada entre os dias 26 de abril e 07 de julho de 2005 e publicada no jornal EntrePosto, de setembro de 2005.

${ }^{94}$ Fonte: Entrevista com o Prof. Dr. Nicolau Dionísio Fares Gualda (Escola Politécnica da USP) para o Jornal EntrePosto (2004)

${ }^{95}$ Esse setor envolve as edificações e o Pavilhão. No pavilhão MLP são comercializadas as hortaliças de folhas, talos, como também, o milho verde. Como as hortaliças são mais perecíveis, determinou-se o horário da tarde (após às 11:00, horário de pico ocorre às 17:00 ) para o seu comércio. No passado essa atividade ocorria durante toda a madrugada. Atualmente o espaço da pedra (módulos) encerra a venda de hortaliças às 20:00. Nas terças e sextas-feiras esse pavilhão é ocupado pelo Mercado das Flores, durante a madrugada até às 11:00 da manhã.
} 
- Os pavilhões de AP's (Armazéns de Produtores).

As edificações desses setores são subdivididas em pequenos estabelecimentos denominados de boxes e módulos ${ }^{96}$, que são alugados pela administração aos permissionários para a atividade. A grande maioria deles é atacadista. Os horários de funcionamento segue os tipos de produto, conforme o quadro que se segue:

Tab. 7: Horários de vendas no atacado

\begin{tabular}{|l|l|}
\hline \multicolumn{1}{|c|}{ SETORES } & \multicolumn{1}{c|}{ Horário e dias de funcionamento: } \\
\hline Legumes & $2^{\mathrm{a}}$ a Sábado, das 8:00 às 21:00 \\
\hline Frutas & $2^{\mathrm{a}}$ a Sábado, das 8:00 às 18:00 \\
\hline Verduras & $2^{\mathrm{a}}, 4^{\mathrm{a}}$ e $5^{\mathrm{a}}$ feiras, das 15:00 às 21:00 \\
& $3^{\mathrm{a}}$ e $6^{\mathrm{a}}$ feiras, das 11:00 às 21:00 \\
\hline Diversos (batata,cebola, coco seco, ovos) & $2^{\mathrm{a}}$ a Sábado, das 9:00 às 20:00 \\
\hline Abóbora & $2^{\mathrm{a}}$ a Sábado, das 2:00 às 6:00 \\
\hline Pescado & $3^{\mathrm{a}}$ a Sábado, das 2:00 às 6:00 \\
\hline Flores & $2^{\mathrm{a}}$ e $5^{\mathrm{a}}$, das 10:00 às 18:00 \\
& $3^{\mathrm{a}}$ e $6^{\mathrm{a}}$, das 4:00 às 11:00 \\
\hline
\end{tabular}

Fonte: site www.ceagesp.gov.br e Jornal Entreposto.

\footnotetext{
96 A pesquisa de Navarro (1992) traz alguns dados que complementam nossa investigação, como: O setor das frutas é composto por 14 pavilhões constituído de 180 boxes, providos de escritório, telefone, área de vendas e sanitários individuais; o setor de Frutas Estacionais é composto por 1 pavilhão de 320 módulos e um segundo pavilhão de 680 módulos; há um pavilhão especial que comercializa melancias e bananas verdes; o setor de legumes é composto de 6 pavilhões com 228 boxes e 306 módulos; o setor de verduras é composto por um pavilhão (MLP) com 260 módulos; o setor da BATATA, CEBOLA,COCO, ALHO e OVOS é composto por 5 pavilhões de 120 boxes (nessa área encontramos a comercialização de produtos de jardinagem, padaria e Casas do Norte)
} 


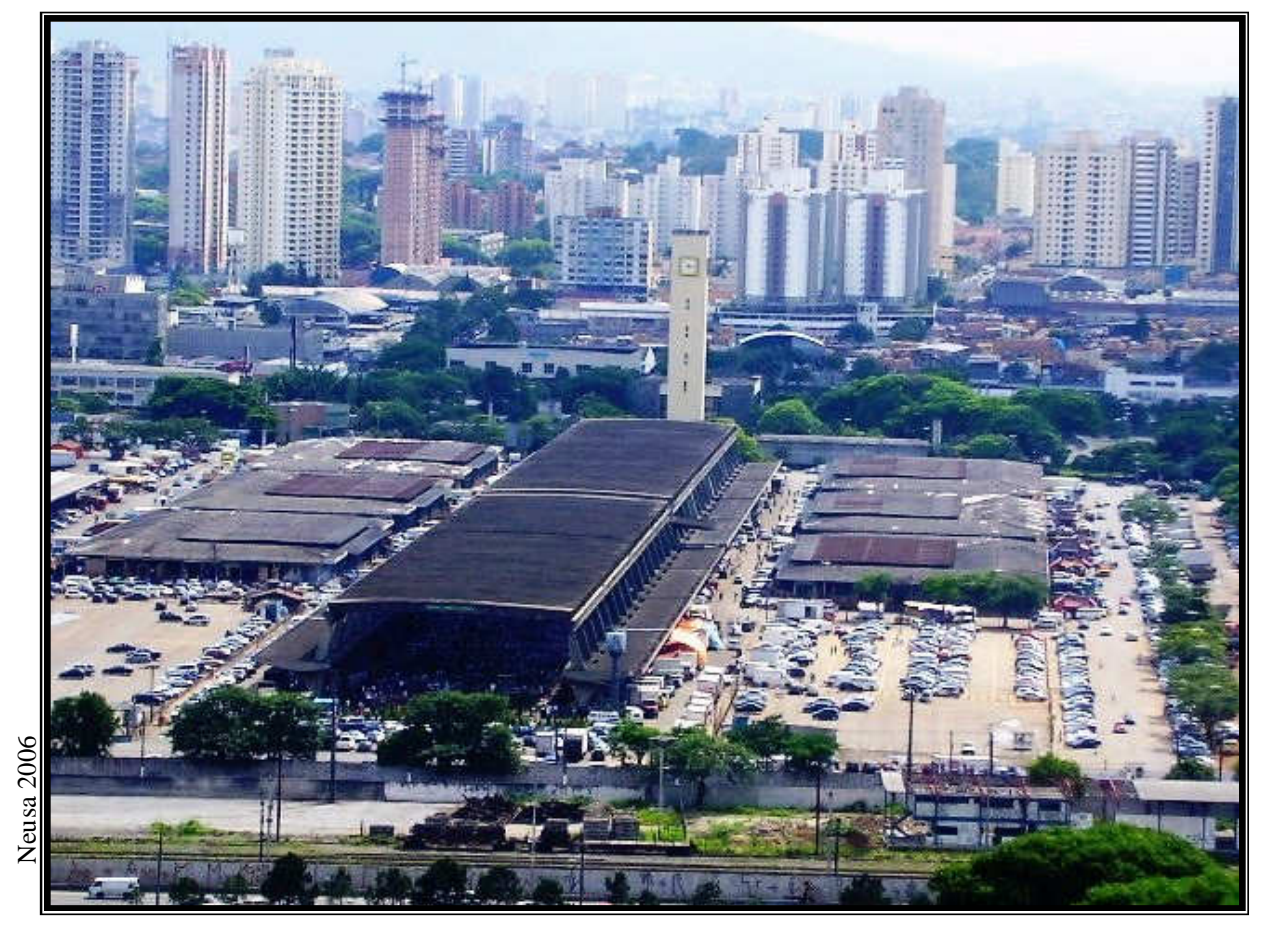

Foto 9:Vista Panorâmica de parte central do Terminal da CEAGESP a partir do Relógio do Jaguaré.

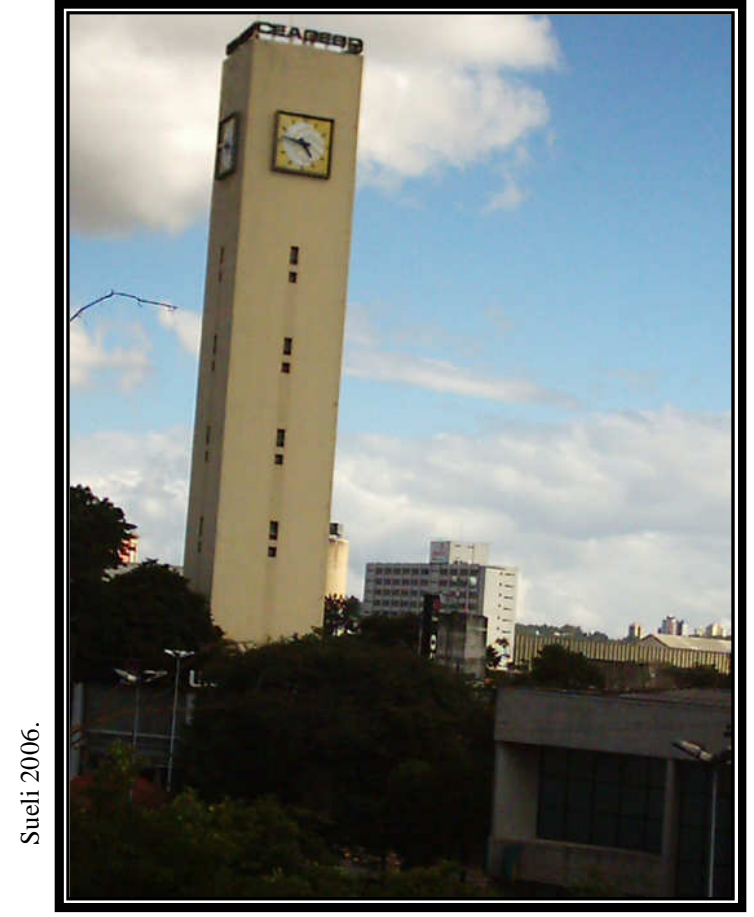

Foto 10 O Relógio Central é o símbolo da CEAGESP

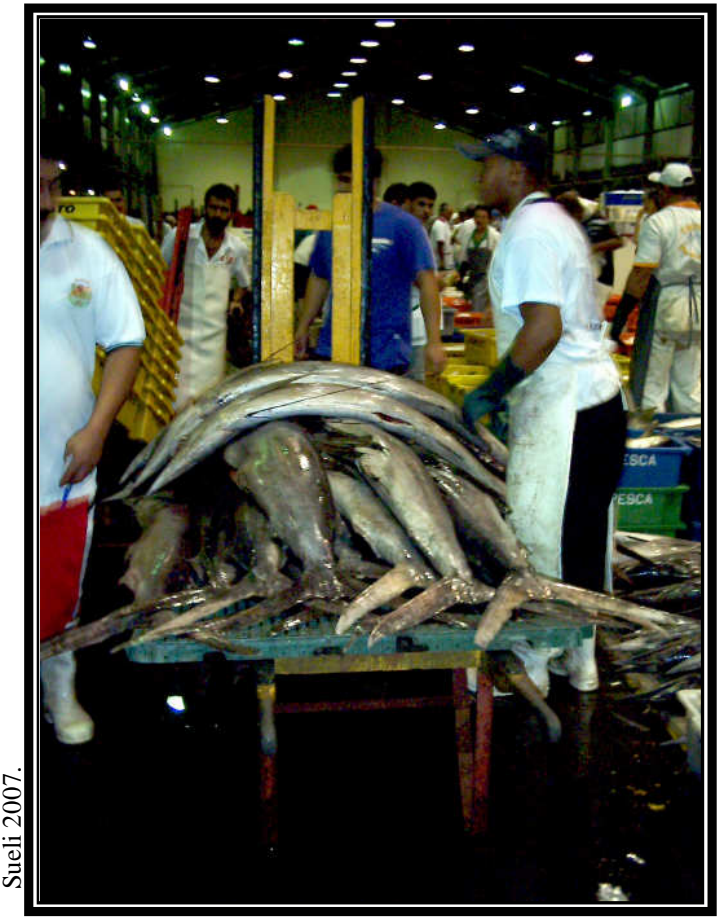

Foto 11 O Mercado do Peixe 
Há outros espaços diferenciados desse conjunto padronizado de edificações de concreto, como a área destinada à comercialização do Pescado. O Mercado do Peixe acontece de terça-feira a sábado, durante a madrugada. ${ }^{97}$ Nessa área há um galpão adequado para essa atividade, com a presença de um frigorífico. Esse local fica próximo da Marginal Pinheiros, conforme mostrado no mapa CEAGESP na Metrópole de São Paulo. Uma parte dessa área também é denominada de Praça do Pescado, e tem acesso pelo portão 13. O setor do pescado reúne 60 atacadistas que comercializam 3,5 toneladas por mês, em um faturamento de $R \$ 11$ milhões mensais. ${ }^{98}$ Comercializa-se diferentes pescados: salmão, sardinha, atum e muitas outras variedades de peixes e frutos do mar. ${ }^{99}$ Veja foto $n^{\mathbf{o}} 11$.

Ao lado do Mercado do Peixe encontra-se um grande galpão destinado ao Sindicato dos Carregadores (SINDCAR). Existem outras sedes de sindicatos espalhadas pelo Terminal, mas que demandam um espaço físico menor. Há também, próximo do SINDCAR, quatro oficinas, voltadas para a manutenção dos carrinhos dos carregadores.

Também, ao lado da Marginal Pinheiros, oposto ao Terminal de Pescado, encontramos o edifício do Silo Vertical. O Silo do Jaguaré, assim denominado, opera recebendo grãos já processados e tem capacidade estática de 20 mil toneladas. Há também o Armazém Convencional, com capacidade para 9 mil toneladas. Apresenta desvio ferroviário de bitola mista (larga e estreita) ${ }^{100}$. Próximo ao silo, está localizada a Unidade Frigorífica e Armazenadora Polivalente (FAP), com capacidade estática de 16.650 toneladas e fluxo operacional de 50 toneladas por hora. Essa área está cedida por permissão remunerada de uso.

Junto à Avenida Gastão Vidigal encontra-se uma grande área, espécie de "pátio", denominada de Praça da Batata, destinada a diversos usos, como: o comércio de plantas e produtos de jardinagem no "atacado", que tem como apoio caminhões baús, e acontece nas segundas e quintas-feiras, das 5:00 às 13:00 horas; um varejão e uma feira dita, noturna, que acontece nas quartas-feiras, das 16:00 às 21:00 horas. Aos domingos, no período da manhã, das 7:00 às 13:00 horas, o espaço é reservado para uma grande feira de automóveis. ${ }^{101}$ Essa feira é administrada por uma empresa especializada, Matel, que aloca o espaço do Entreposto. Essa área, apesar de ser um espaço totalmente aberto, é denominado de Pavilhão BPC, e pode ser acessado pelo portão 7. Ao lado dessa área, no espaço interno da Companhia, encontramos

\footnotetext{
${ }^{97}$ Fonte: Revista da Folha, 13 de março de 2005. O Varejo ocorre nas quartas-feiras, das 16 horas às 22 horas, sábados: 7h às $12 \mathrm{~h} 30$ e domingos: $7 \mathrm{~h}$. às 13:30. O atacado ocorre de terça a sábado: $2 \mathrm{~h}$ às $6 \mathrm{~h}$.

${ }^{98}$ Fonte: Jornal Entreposto, julho de 2006

${ }^{99}$ Fonte: Folder organizado pela CEAGESP.

${ }^{100} \mathrm{O}$ endereço do Silo é rua C, s/ n ${ }^{\text {o }}$ (Travessa a Av. José Cesar de Oliveira, $111^{\text {a }}$ Jaguaré. SP)

101 A primeira feira do automóvel aconteceu dia 15 de janeiro de 2000, no Sábado e noticiada pelo Jornal Elo,janeiro de 2000.
} 
a Escola Nossa Turma, que atende crianças de favelas vizinhas e do conjunto habitacional Maderit.

Uma das edificações, denominada de LEA (Lojas, Escritórios e Administração), próxima, também, da Avenida Gastão Vidigal, foi destinada, no seu piso térreo, para a instalação de comércio e serviços diversos, como padaria, farmácia, lojas, dentistas, redação do jornal, Rádio EntrePosto, correio e restaurantes, além da parte administrativa. No piso superior, encontramos parte do setor administrativo da Companhia. Existem outras edificações destinadas à administração e gerenciamento da Central. Há, também, algumas edificações vazias. Logo na entrada principal da Central, ainda próximo à Avenida Gastão Vidigal há uma concentração de agências bancárias (Banco do Brasil, Unibanco, Real), com edificações que seguem uma disposição diferenciada do conjunto arquitetônico padronizado, que marca a paisagem de construções do Terminal.

No espaço central do Terminal, encontra-se um pavilhão coberto, com uma área de 20 mil metros quadrados, identificado como MLP. Neste local funciona a Feira de Flores, (às terças e sextas feiras, com início às 02:00 e término às 11:00 horas). Após o término dessas atividades, entra o Varejão de Verduras, Legumes e Milho. Aos sábados e domingos pela manhã acontece uma grande feira, o varejo. Esse espaço é delimitado com uma pintura no chão e uma numeração, que é denominada de pedra pelos permissionários, e considerado um módulo pela administração. Essa pedra é alugada pela administração aos permissionários. $\mathrm{Na}$ troca de mercadorias a serem comercializados é tocada uma sirene e entra a equipe de limpeza ${ }^{102}$ para preparar o espaço, para os permissionários das verduras entrarem, nas laterais vemos os caminhões e os carregadores aguardando para colocar a mercadoria nas "pedras". Veja as fotos $n^{\circ} 12$ e 13 , que mostram o pavilhão ocupado de duas formas diferenciadas, conforme o dia e o horário.

\footnotetext{
${ }^{102}$ A limpeza do Terminal é terceirizada.
} 


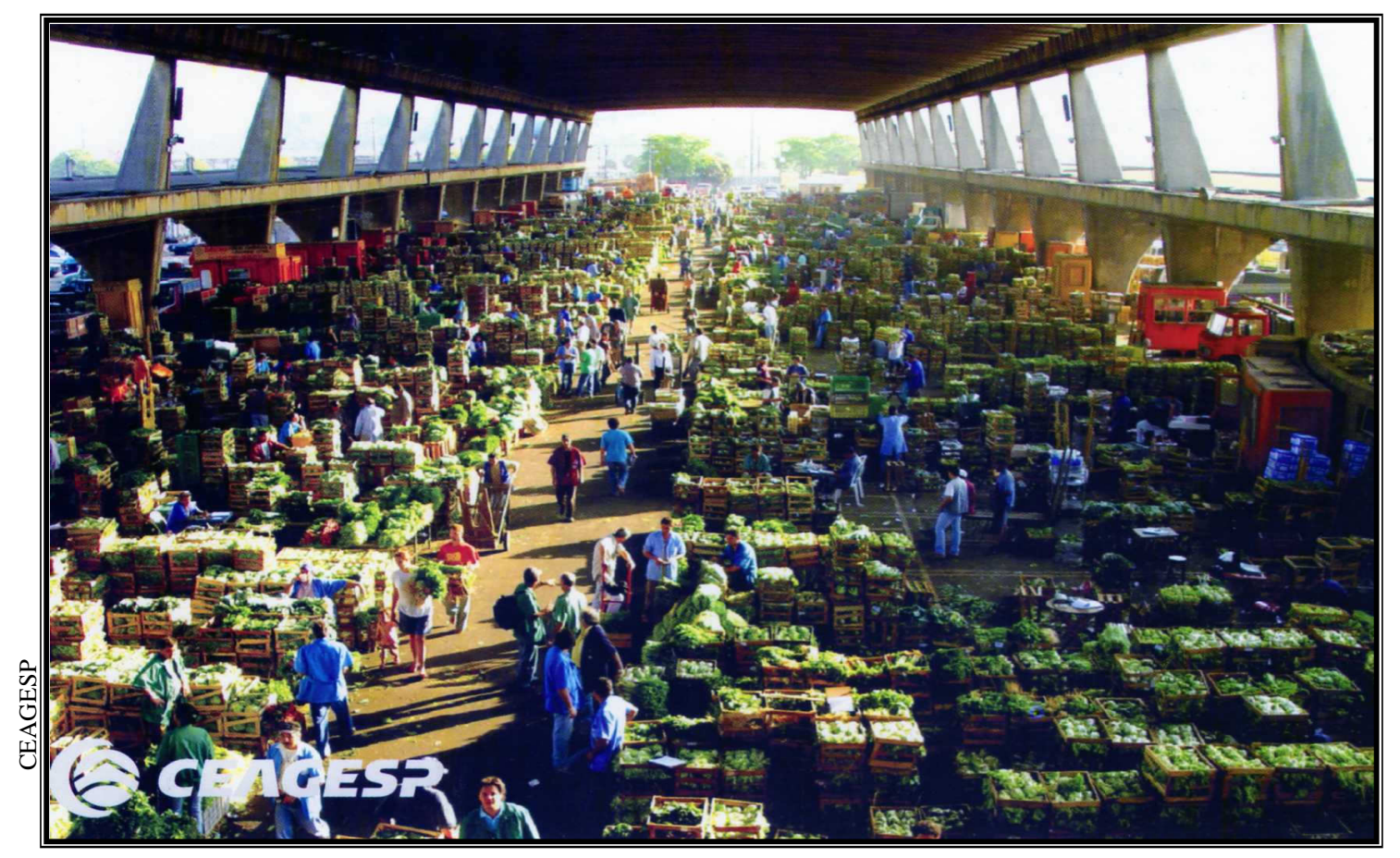

Foto 12: Pavilhão denominado Mercado Livre do Produtor comercializando Verduras.

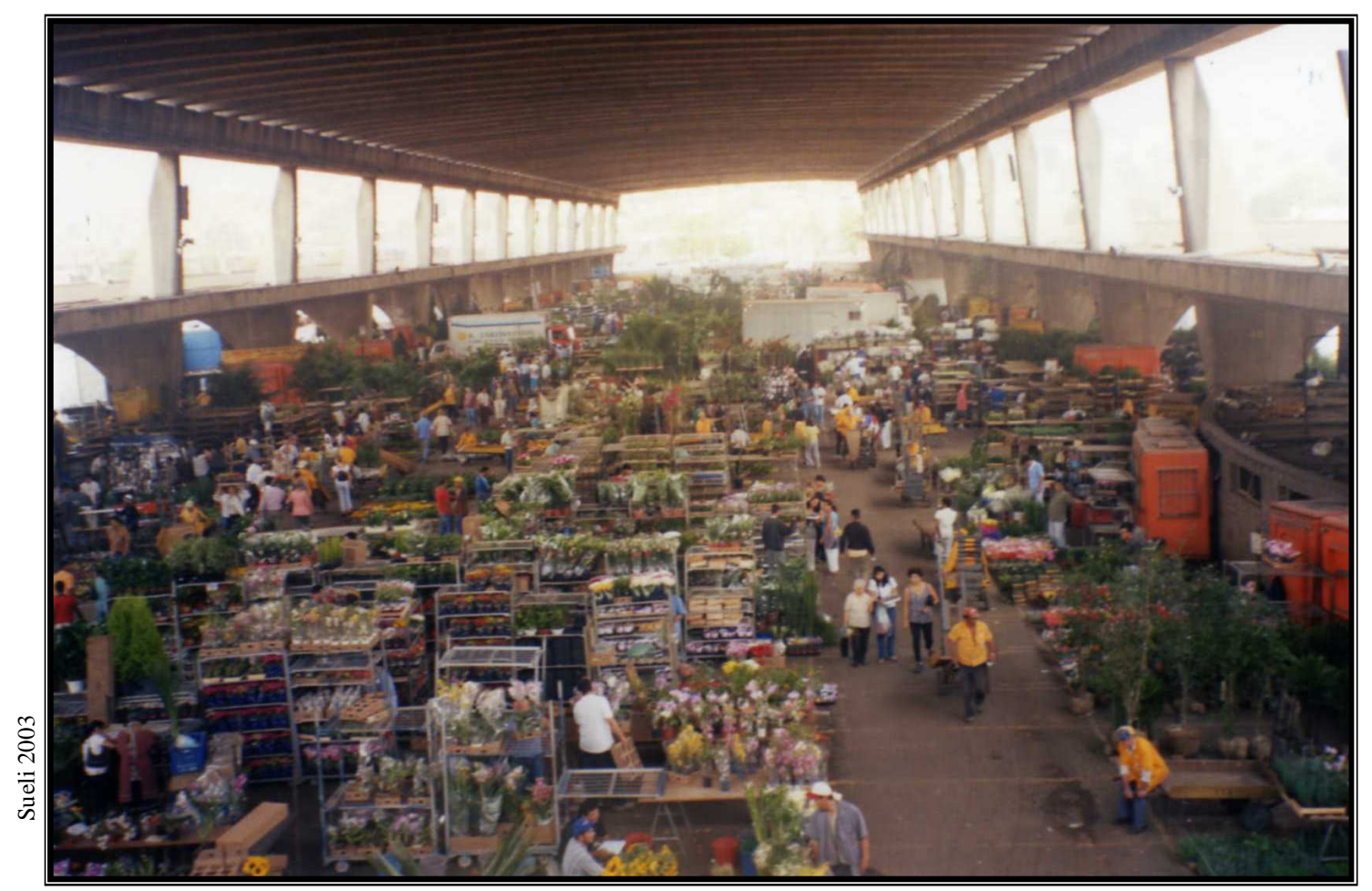

Foto 13:Feira das Flores no Pavilhão do MLP 
No Terminal há restaurantes de gastronomia variada, que servem a diferentes grupos sociais. Dois restaurantes ${ }^{103}$ servem refeições por quilo com cardápio diverso. No entanto, o que nos chamou a atenção foi a quantidade de "quiosques" voltados para alimentação, espalhados pelo Entreposto. Essas lanchonetes, que apresentam um ambiente simples, sempre trazem em seu cardápio pratos que compõe a culinária nordestina. As refeições são geralmente porções generosas e reforçadas, para atender as necessidades e os hábitos da maior parte de sua clientela, composta por caminhoneiros e carregadores, que consomem uma refeição rica em calorias devido à exigência de seu trabalho diário. Encontramos nos boxes do setor da Batata duas "Casas do Norte", comercializando produtos típicos da culinária nordestina. Isso reforça a nossa pesquisa, sobre a presença nordestina no Terminal, evidenciada na paisagem pela delimitação de seu território de trabalho.

Foram projetadas áreas destinadas à circulação de grandes veículos ${ }^{104}$, para o estacionamento $^{105}$ desses caminhões, tanto para carga e descarga, e também para aguardar o tempo para completar o circuito entre a descarga e o novo carregamento. Existem entre essas edificações amplos estacionamentos, próximos das plataformas, assim como posto de abastecimento e apoio voltados para o caminhão e o caminhoneiro. $\mathrm{Na}$ área interna, ao lado da Av. Gastão Vidigal há um estacionamento privado - Point Park - para os veículos pequenos, principalmente para atender parte das necessidades do Varejão e do Mercado das Flores. Existem 1.700 veículos cadastrados autorizados para adentrar o Entreposto, que pertencem a funcionários, permissionários e ambulantes. Porém, o Terminal possui para eles uma capacidade de 400 vagas, ocasionando problemas de excesso de veículos. ${ }^{106}$ Em outubro de 2004, novas regras de circulação foram impostas para os veículos pequenos, restringindo a sua entrada.

Um enorme relógio de quatro faces, construído em 1974, ${ }^{107}$ com mais de 15 metros de altura, acabou simbolizando a paisagem urbana da CEAGESP, cercado por uma pequena praça, que ocupa a área central, próxima da entrada principal da Companhia (Ver foto $\mathrm{n}^{\mathrm{o}} 10$ ).

\footnotetext{
103 Em 2003, havia um restaurante japonês um pouco mais sofisticado, que atendia o grande número de freqüentadores e permissionários, na maioria descendentes da comunidade nipônica. Ele ocupava o local do famoso restaurante que servia a sopa de cebola nas madrugadas frias de São Paulo. Hoje essa edificação está vazia.

104 A pesquisa de Navarro (1992) registra 280.000 metros quadrados de ruas e avenidas e 27.900 metros quadrados de estacionamentos.

105 Há grandes áreas para o estacionamento de veículos ao lado e atrás do MLP, utilizada às terças e sextasfeiras, para atender às necessidades das vendas de flores, plantas, etc. e, aos sábados e domingos, pela manhã para atender ao varejão, quando também outras áreas destinadas a caminhões para carga e descarga são usadas com a finalidade de estacionamento de veículos de usuários destes varejões de fim-de-semana.

${ }^{106}$ Fonte: EntrePost, outubro de 2004

${ }^{107}$ O seu maquinário foi trocado, no ano de 2005, pela Dimep, a mesma empresa que o construiu .
} 
Há espaços ocupados por alguns projetos sócio-ambientais que são desenvolvidos na Companhia, como o Banco de Alimentos (Cozinha-Escola) que administra as doações de alimentos para entidades filantrópicas e desenvolve o programa de combate à fome denominado "Fome Zero". O programa de reciclagem envolve uma série de ações, entre elas, o aproveitamento dos resíduos orgânicos. Parte dos produtos impróprios para o consumo humano são transformados em ração animal, parte em adubo orgânico, produzido em uma pequena área destinada a uma composteira. Existem também cursos de compostagem para agricultores e chacareiros que circulam no Terminal. Foi implantado um Box de produtores cooperados para comercializar os produtos orgânicos. E por fim, a já referida Escola Nossa Turma, localizada na área do Entreposto, voltada para as crianças das comunidades carentes do entorno do Terminal.

Veja a representação, Mapa $n^{\circ}$ 5, para melhor entender a área interna do Terminal. 


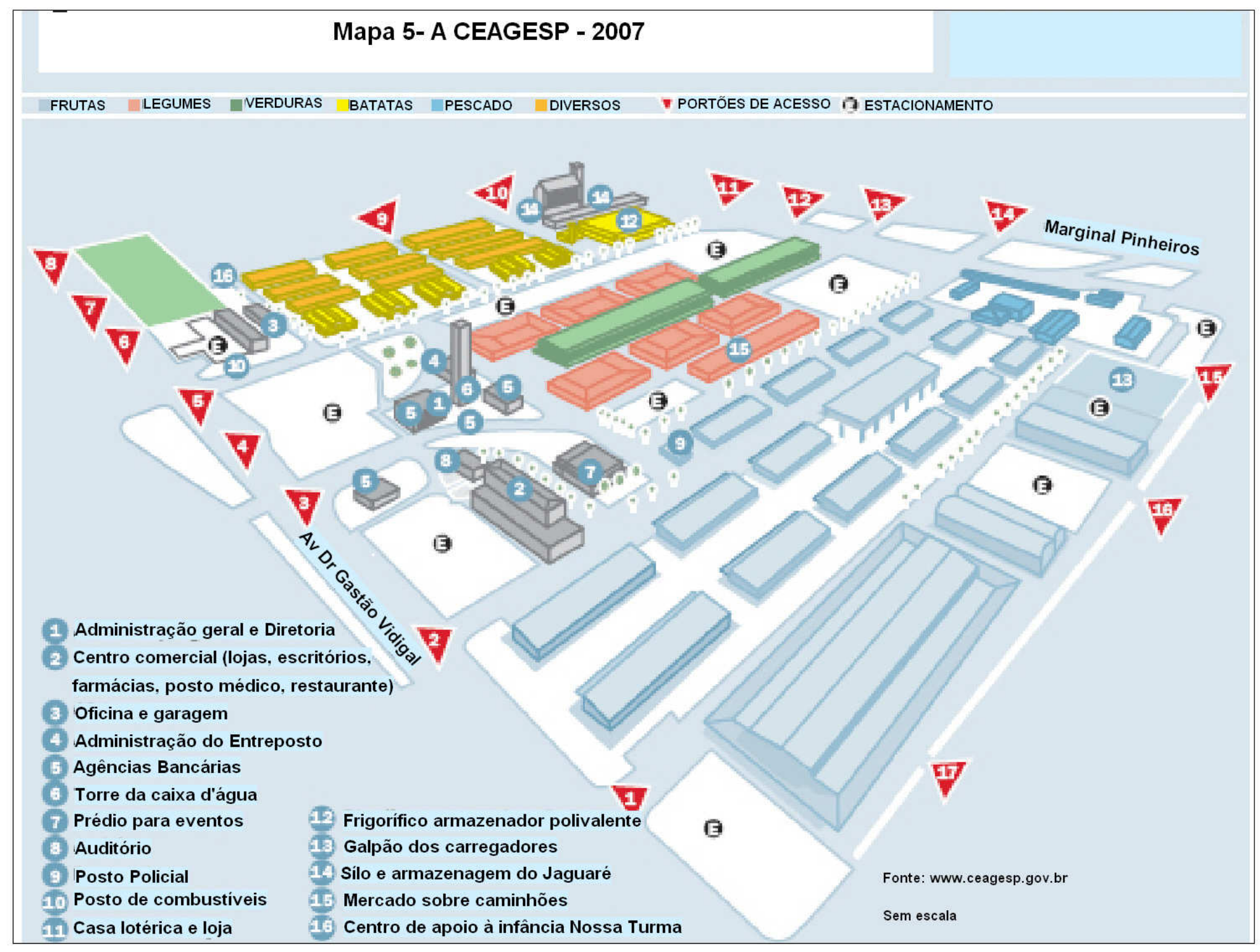


O índice de ocupação das áreas para serem alocadas gira em torno de 97\%, sendo que há 109 áreas em licitação Isso não significa que elas estão vazias, pois 80 delas estão ocupadas, em modalidade de ocupação provisória.

A CEAGESP, nas terças e sextas-feiras pela manhã, além da função de abastecimento, ganha um novo caráter, que é o de centro turístico. Nesses dias ocorre a Feira das Flores instalada no Pavilhão MLP, de 20 mil metros quadrados. Devido à expansão dessa atividade, atualmente ela ocupa também o estacionamento lateral. A Feira das Flores, em dias regulares, costuma receber 3 mil pessoas. São paisagistas, comerciantes ou mesmo o consumidor varejista. Essa Feira reúne 1100 produtores, que vendem no atacado e no varejo, plantas e flores de vaso e de corte, mudas de árvores, arbustos e uma variedade de acessórios para jardinagem. Observamos, em campo, alguns ônibus com grupos de terceira idade e pessoas de outros municípios e estados, passeando, admirados entre orquídeas, rosas ou qualquer outra flor exótica. É uma verdadeira exposição de plantas e acessórios para a jardinagem. Essa Feira é citada nos guias turísticos e publicações sobre lazer em São Paulo.

Quem pensa que pelo Terminal só circulam frutas, verduras, legumes e pescado, se equivoca. A Ceagesp possui um cadastro para cafezeiras, vendedores de roupas, sapatos, tênis, comida, pacote de viagem, padaria e até uma rádio por Alto Falante - a Rádio EntrePosto.

Os periódicos internos apareceram já nos anos 70, durante os governos militares. Havia uma publicação oficial ligado à administração da Companhia que editava um jornal denominado CEAGENTE. ${ }^{108}$ Os artigos enfocavam questões ligadas ao dia à dia do CEASA. Traziam também informações sobre campeonatos de futebol, dominó, botão; iniciativas dos funcionários como biblioteca, "pic-nic", festas de Natal. Mostravam os chamados “funcionários padrão" e as homenagens aos funcionários da administração, enfocando suas atividades recreativas. Publicavam todos os benefícios concedidos pela diretoria administrativa aos funcionários. Parecia que os outros trabalhadores não existiam, e principalmente, o carregador!

Depois identificamos um outro jornal, que existe no Terminal, denominado ELO. Este não possui uma periodicidade regular e é vinculado ao Sindicato dos Permissionários, trazendo questões vinculadas a essa categoria, além elementos do cotidiano do Terminal. O jornal Elo no ano 2000 chegava a sua $20^{\circ}$ edição. Ele ainda se mantém, porém sem a mesma

\footnotetext{
108 Encontramos edições do CEAGENTE até 1984, nº 90, ano IX. Muitas edições se perderam. Funcionários contam que havia uma funcionária que fez uma faxina e que se desfez de muitos materiais que hoje poderiam auxiliar a reconstruir a história da Companhia. Assim, encontramos pouca documentação e apenas algumas edições que restaram desse jornal.
} 
periodicidade anterior, tendo mais um formato de boletim, pois os patrocinadores migraram, com o mesmo grupo de jornalistas que o organizava, para criar o jornal EntrePosto, um novo periódico.

A rádio e o jornal apareceram em junho de 2000 e sobrevivem com patrocínio de Grandes Empresas - como as concessionárias, a Mercedes-Benz, General Motors, Volkswagen, Volvo e Ford -, construtoras, além dos maiores comerciantes do Entreposto. O jornal tem uma edição mensal e aborda uma diversidade de assuntos relativos aos interesses da comunidade do Terminal. Ele se auto-designa "Um jornal a serviço do agronegócio" e circula no Terminal e em pequena parte da região Oeste da cidade. Com esse perfil, ele abre espaço para artigos sobre o agronegócio, investimentos, tecnologia na agricultura, embalamento, transporte de alimentos, Feiras e Exposições do setor, artigos sobre a propriedade dos alimentos, os diferentes problemas no Terminal, fatos e eventos que ocorrem no Terminal e curiosidades. O Sindicato dos Carregadores tinha um espaço reservado no jornal para publicar seus textos em que discutia a saúde do trabalhador, anunciava as missas que promovia e divulgava as conquistas da categoria. Por causa de um estremecimento nas relações, o presidente do sindicato deixou de publicar no jornal.

O Terminal possui um conjunto de atividades econômicas, como padaria, farmácia, salão de beleza, banca de jornal, lotérica, agências bancárias, correio, agência de viagens, escola, oficinas, posto de gasolina, enfim, atividades que permitem uma determinada autonomia e dinâmica nesse espaço. ${ }^{109}$ A administração da Companhia usa o seguinte jargão para o Terminal da Vila Leopoldina "A cidade que nunca pára". A comunidade que circula e gira entorno da companhia compara o espaço do Terminal da Vila Leopoldina (CEAGESP) a uma cidade, inclusive com os problemas comuns, considerando que em seu entorno há a ocorrência de favelas, moradias precárias, moradores de rua e violência urbana.

\subsubsection{O Entorno do Terminal e os vestígios da migração}

Nossa área de estudo se delimita a partir da CEAGESP, enquanto espaço de polarização e atração. Nosso propósito é compreender esse entorno no que se refere aos elementos da paisagem como indicativos da mobilização. Esses elementos podem estar tanto no distrito do Jaguaré, como no da Vila Leopoldina. Entendemos que a Vila Leopoldina é muito mais do que os elementos que destacamos no entorno da CEAGESP, porém o nosso

\footnotetext{
${ }^{109}$ No início da pesquisa, em 2003, havia um posto policial, atualmente desatividado. As ocorrências policiais são registradas na delegacia de policial localizada ao lado do Terminal, na Av. Gastão Vidigal.
} 
critério está focado nos indicadores de mobilidade, como o albergue, os moradores de rua, o conjunto habitacional e as favelas, e não em um estudo de bairro e nem em um estudo de distrito. Queremos também lembrar que não pretendemos desenvolver um estudo das transformações da Vila Leopoldina enquanto um distrito; segundo a sua delimitação oficial. Nosso ponto de referência é a área do Entreposto, sua centralidade Transborda a delimitação do terreno destinada a essa circulação, onde uma série de serviços e atividades foram sendo criadas, mobilizadas e reorganizadas conforme o Mercado exigia e exige para a sua ampliação e reprodução. Vamos fazer um rastreamento das diversas formas de trabalho e mobilidade que essas atividades apresentam na paisagem urbana, as quais denominamos de vestígios da mobilidade.

A Companhia, pela sua dimensão na circulação de mercadoria e sua importância, atraiu uma série de serviços e comércio que estão interligados às necessidades e funções do centro de abastecimento. A paisagem das ruas próximas apresenta uma diversidade de estabelecimentos comerciais que demonstram esse vínculo. Vejamos abaixo quais setores comerciais que estão presentes nesse entorno:

- Concessionárias de automóveis, caminhões e tratores: Chevrolet, Cintröen, Ford, Fiat, Mercedes-Benz, Nissan, Wolkswagen, Honda, Peugeout, Renault e Toyota. Atualmente, essas concessionárias comercializam veículos de pequeno e grande porte. Outros estabelecimentos comercializam acessórios para caminhões e tratores, autopeças, e prestam serviço de mecânica para atender à grande quantidade de caminhões que circulam na área. Estima-se que são 17.500 veículos, dos quais 10 mil são caminhões que trafegam no local, atraídos pelo Entreposto.

- Lojas de embalagens plásticas, papelão e outras necessidades para a comercialização dos produtos hortifrutigranjeiros.

- Comércio de plantas ornamentais, que surgiu com a chegada do Comércio de Flores do Pavilhão MLP e, posteriormente, com os caminhões que comercializavam plantas em outros espaços da Companhia. Existem no entorno grandes estabelecimentos desse setor. Essas lojas buscam atender um consumidor mais sofisticado, que estimula o mercado da jardinagem e paisagismo, cujo crescimento é vertiginoso.

- Comércio de insumos agrícolas (adubos, sementes, defensivos, instrumentos agrícolas, etc) na Avenida Imperatriz Leopoldina e ruas transversais.

- Atividades de economia informal, como a atividade de produção de caixas e pallets de madeira, denominada de caixaria. 
- Há uma concentração de restaurantes japoneses na Avenida Imperatriz Leopoldina e proximidades, assim como lojas de equipamentos de pesca, no entorno da Companhia. Podemos vincular esses estabelecimentos ao Mercado do Peixe e a presença dos migrantes e descendentes de japoneses ${ }^{110}$ que foram atraídos e inseridos no comércio de hortaliças, verduras, flores e legumes. Encontramos muitos descendentes ou japoneses como permissionários, donos de boxes ou de pedras Esses aos poucos estão sendo substituídos pelos nordestinos mais capitalizados.

Entretanto, essa breve caracterização da importância da CEAGESP como espaço mobilizador não dá conta de uma realidade muito mais complexa, que se instalou no entorno da Companhia, a partir da facilidade de se conseguir alimentação e trabalho, mesmo que em condições de precariedade.

Identificamos uma grande quantidade de moradias precárias que se formaram antes e após o período de instalação do CEAGESP, em 1966. Os migrantes nacionais chegavam na cidade e se instalavam nas periferias e nas áreas mais baratas e insalubres; ocupavam os espaços vazios, como fundos de vales, encostas de morros e a beira das linhas ferroviárias; ampliava-se assim o número de favelas e moradias precárias, como os cortiços.

Os espaços próximos da CEAGESP apresentam os maiores indicadores de pobreza da subprefeitura da Lapa. Vejamos alguns deles: o Conjunto Habitacional Maderit (antiga Favela da Maderit), Viela Um -Votorantim, Manoel Bandeira, a Favela Nova Jaguaré, Morro do Continental (Nossa Senhora das Virtudes) e adjacências (Sambra, Tancredo Coutinho, Antonio de Souza Nochese, Andries Both, Sem Nome), ainda no Jaguaré - as favelas Torres de Oliveira e Beira Linha; Parque São Domingos, as famílias removidas do viaduto do CEASA (Mofarrej), Jd. Haddad ${ }^{111}$ e o espaço da Caixaria. Uma parte dos moradores dessas áreas sobrevive de algumas atividades internas ou externas ao Terminal; trabalham na coleta de materiais recicláveis e com pequenos "bicos" no Entreposto, além, da coleta das sobras de alimentos da CEAGESP. Reconhecemos essas áreas como vestígios da mobilidade do trabalho, pois aparecem em forma de moradia precária na paisagem urbana, 'alocando' as forças de trabalho que foi mobilizada pelo capital. Vamos fazer um reconhecimento de

\footnotetext{
${ }^{110}$ A colônia japonesa possui hábitos da prática da pesca, como lazer, em sua cultura.

${ }^{111}$ Foram removidas 50 famílias do Viaduto do CEASA, contudo várias ainda permanecem. Em 2003 foram removidas outras 50 famílias do Viaduto do Mofarrej, proximidades do CEAGESP. Recentemente, onde será instalado o complexo da Febem, foram novamente retiradas algumas famílias do terreno, anteriormente designado (2006).
} 
algumas dessas áreas, que identificamos como vestígios da mobilidade na paisagem, caracterizando esses vários conjuntos de moradias precárias no entorno do Entreposto.

O Conjunto Habitacional Maderit, formado por um conjunto de prédios baixos populares, é composto por 400 unidades habitacionais. Esse projeto, denominado de Cingapura, inaugurado na gestão do Governo de Paulo Maluf, foi uma iniciativa que alojou parte dos moradores da favela Maderit, que permanece até hoje e se estende ao longo da linha de trem desativada, fazendo limite com o Entreposto.

A Favela Casinha de Cachorro, localizada no Viaduto Mofarrej, mais conhecido como Ceasa $^{112}$, foi removida em 2002. Além de moradia, o espaço servia como local de produção e comercialização de casinhas de cachorro, através do reaproveitamento das caixas de frutas, verduras ou outros produtos que a CEAGESP descarta. As 54 famílias foram removidas para um abrigo provisório, no Jardim Humaitá, distrito da Vila Leopoldina. A produção das casinhas de cachorro foi instalada em um terreno do Estado na Marginal Tietê. Atualmente, essa área foi designada para a construção da Febem e novamente essas famílias foram removidas.

A favela Andries Both, composta por 80 barracos, e a Favela da Sambra, composta por 100 barracos, situados no Jaguaré, mantém alguns vínculos, apesar de estarem separadas pelo Rio Pinheiros. Seus moradores buscam parte de sua alimentação e trabalho no Entreposto. Observamos em diferentes horários um grande fluxo de pedestre atravessando a ponte do Jaguaré ou se deslocando pelo transporte público. ${ }^{113}$

A Favela Nova Jaguaré composta por 3000 barracos, foi estudada por SILVA (2006) que mostra a gênese desse núcleo de moradias precárias, anterior à presença da Companhia. As primeiras ocupações da área foram nos anos 30. Observamos em campo, uma faixa que anunciava uma festa, comemorando os 50 anos da "Vila Nova Jaguarée'114. Assim, seria errôneo associar o surgimento desta favela ao CEAGESP. Entretanto, vemos que o seu adensamento ocorre posteriormente à transferência da Companhia, que segundo a autora,

\footnotetext{
112 O documentário "Casa de Cachorro", direção Thiago Villas Boas. ECA (2001) registra parte do drama da remoção violenta realizada pela prefeitura em agosto de 2000. O vídeo parte do relato desses trabalhadores, a maioria migrantes nordestinos, os quais mostram seu trabalho e moradia no mesmo local e a comercialização das casinhas nas Marginais do Rio Pinheiros e Tietê.

${ }^{113}$ Fonte: Evelyn (1988:96) e dado obtido na experiência do ano de 2001, em que exerci a representação de Conselheira de Transportes pela Subprefeitura da Lapa, nesse período organizamos uma reunião com moradores do Jaguaré no salão paroquial da Igreja São José, com o apoio do Padre Roberto. Estiveram presentes, principalmente, moradores da favela Nova Jaguaré. Uma das sugestões que apareceu durante essa reunião foi a de que se fizesse uma nova ponte que ligasse a favela ao CEAGESP. Essa proposta, que parecia absurda, do ponto de vista dos planejadores urbanos, demonstrava a forte ligação desses moradores com o Entreposto. Além de encontrarmos em nossas entrevistas carregadores temporários de Inhumas (PI) residindo na casa de seus primos (carregadores), que são moradores das favelas no Jaguaré.

${ }^{114}$ Agosto de 2006 na rua Baepentiba, na Igreja São José.
} 
ocorreu com maior intensidade nos anos 80 e 90. Encontramos também, no cadastro dos carregadores, o vínculo entre residência e trabalho, bem como na pesquisa de Evelyn (1988), com os seus entrevistados que residem no Morro do Continental e nas favelas do Jaguaré, e trabalham no Entreposto. (Ver foto $n^{\circ} 14$ ).

Uma das moradoras relata que os donos dos boxes ${ }^{115}$ já tem designada uma família para doar os alimentos, mercadorias que não servem para comercializar, como se houvesse um cadastro de famílias e vínculos estabelecidos por muitos anos entre os doadores e os receptores.

Observa-se uma grande circulação de pessoas no seu entorno, que saem do Terminal com sacolas, carrinhos, caixas cheias de frutas, legumes, verduras e outros produtos hortifrutigranjeiros. Essa mercadoria é transportada de diversas maneiras: por peruas velhas, nos ônibus ou em uma grande marcha a pé para o seu consumo direto Também são transportadas para revenda, como no caso dos "vendedores de milho verde", que encontramos nas calçadas, com uma estrutura precária de apoio. Essa população, diariamente se mobiliza para buscar os alimentos no Terminal, diminuindo os custos de sua reprodução. Nem sempre são os moradores das proximidades que realizam essa marcha até o Terminal. Encontramos nos pontos de ônibus pessoas com carrinhos de feira, sacos e sacolas que vêm de longe buscar alimentos para consumir ou revender.

A Favela da Caixaria (veja foto, $\mathrm{n}^{\mathrm{os}} 15,16$ e 17), com 150 barracos, e a Favela Manoel Bandeira $^{116}$, com 200 barracos, na Vila Leopoldina, e a Favela da Viela Um/Votorantim, possuem um vínculo ainda maior com a CEAGESP, em relação ás favelas do Jaguaré, em razão de agregar, um espaço particular de trabalho que depende das embalagens de madeira reutilizáveis da Companhia. Essas áreas denominadas de caixarias ${ }^{117}$ são apoiadas por uma rede social de nordestinos, ou melhor, paraibanos, predominantemente. Eles ocupam as calçadas desde o início da implantação do Terminal, na década de 60, porém, só no ano de 2003, ganharam um terreno da prefeitura, e uma parte deles organizou e fundou uma cooperativa. Outra parte continua a ocupar e controlar diferentes pontos das calçadas, nos quais comercializam as caixas com os agricultores ou permissionários da CEAGESP. Os donos dos pontos trazem seus conterrâneos para "bater ripa" ${ }^{" 118}$, isto é, martelar as caixas para eles. No entanto, o mercado imobiliário que investe em empreendimentos de alto padrão, está pressionando a sua saída e reordenando essa ocupação. Uma construtora que comprou parte

\footnotetext{
1153800 permissionários que comercializam os produtos hortifrutigranjeiros.

116 Rua Jupiaçu

117 Atividade que envolve a compra, a recuperação e a venda de caixotes de madeira.

118 Expressão que denomina os trabalhadores que recuperam as caixas de madeira, vinculados à atividade da caixaria.
} 
do terreno, cedeu outra área, no município de Osasco, para os moradores que trabalham na recuperação de caixas vazias da CEAGESP manterem a sua atividade. Essa população está indo para o município de Osasco, na Grande São Paulo, e outra parte da população está mudando de atividade. ${ }^{119}$ A aceleração desse processo ocorre a partir do início de 2006. Simultaneamente ocorre um outro processo de modernização, que corresponde à mudança das embalagens. A caixa de madeira reutilizável, denominada de "caixa $\mathrm{K}$ " 120 , foi proibida pelo Ministério da Agricultura, que exige embalagens mais higiênicas, reduzindo os desperdícios. O mercado está buscando soluções alternativas e mais baratas, adotando o discurso da modernização. Esse processo de modernização das embalagens, somado a valorização da área pelo capital imobiliário provoca uma mobilidade do trabalho, expulsando esses trabalhadores do entorno do Terminal.

${ }^{119}$ Conforme a informação de José Aparecido da Silva, trabalhador da caixaria e Entreposto, janeiro de 2007.

${ }^{120}$ A caixa de madeira recebe essa denominação porquê no passado serviam para carregar o querosene, que em inglês se escreve Kerosene. 
Mapa 6: A CEAGESP e seu Entorno

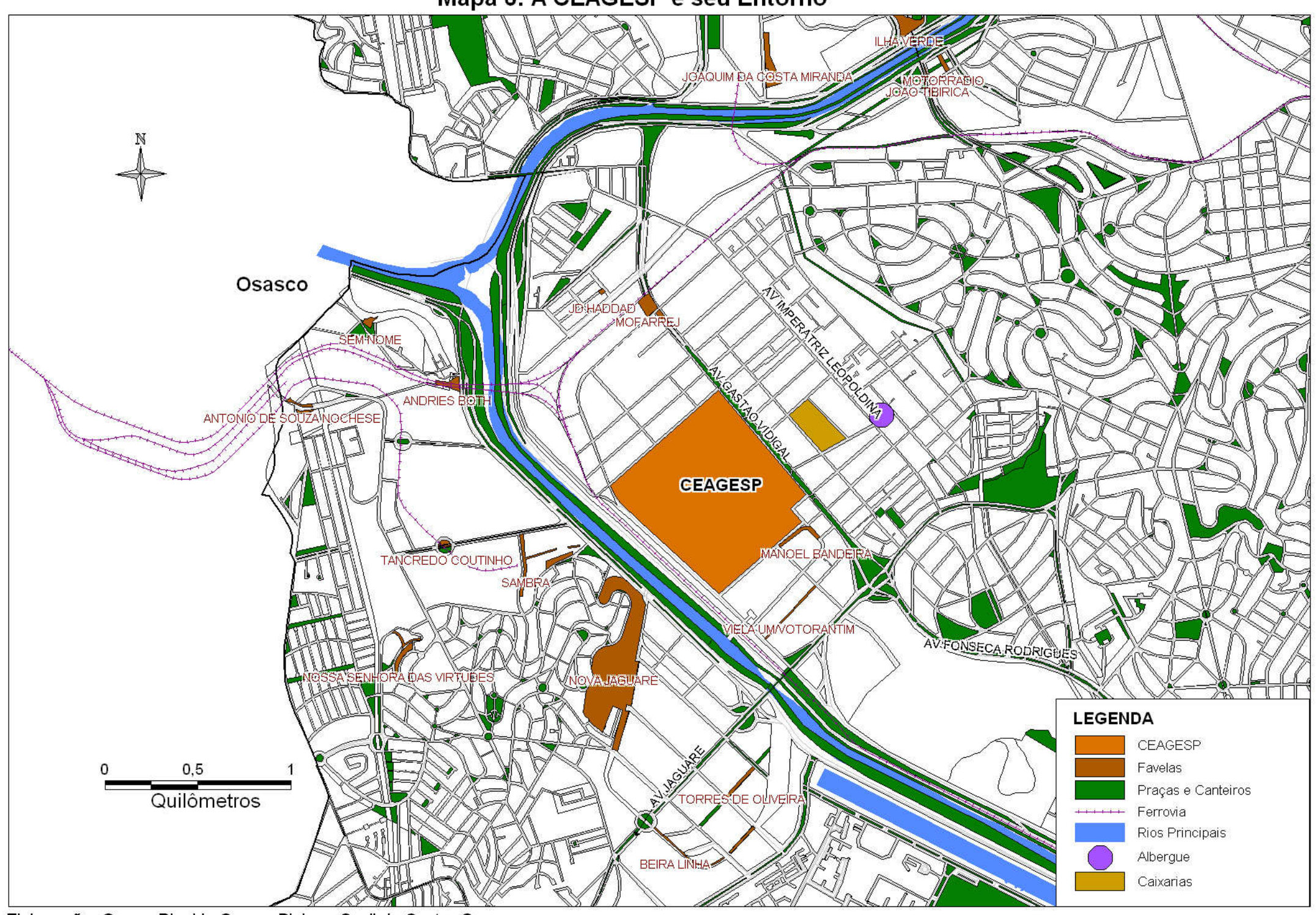


O Diagnóstico do Plano Diretor ${ }^{121}$ do município, que teve na sua elaboração a participação da população, identifica as áreas de maior concentração de pobreza da área da Subprefeitura da Lapa. Vejamos o que afirma esse documento:

Já os moradores de Vila Leopoldina alertam para a migração de carroceiros, catadores de lixo, dentre outros moradores de rua, vistos como ameaça aos moradores do distrito com a prática de atos ilícitos. Tal situação além de seu aspecto social deverá também ser vista sob o aspecto de segurança pública, podendo ser previstas Bases Comunitárias de Segurança nesses locais, com o apoio das empresas prestadoras de serviços e comerciais existentes na região, para coibir os atos ilícitos mencionados pela população.

Os moradores de Vila Leopoldina reivindicam áreas destinadas ao atendimento social, que inclua atendimento à saúde, à educação, aos esportes e lazer além de campanhas educativa voltadas à compreensão da responsabilidade de cada cidadão do significado da cidadania." $(2003: 56)^{122}$.

Nesse documento é reconhecida a centralidade da CEAGESP, visto como um equipamento institucional de grande porte, com uma imensa área de comércio atacadista. Além dos indicadores de manifestação da mobilidade do trabalho que apontamos acima, encontram-se no entorno da área do CEAGESP muitos galpões vazios que outrora foram ocupados por indústrias, que fecharam ou se transferiram para outros lugares. $\mathrm{O}$ uso residencial deste entorno também está presente, entretanto em plena metamorfose, pois antes a Vila Leopoldina caracterizava-se por um bairro de pequenos sobrados ou casas térreas, em que residiam, muitas vezes, os operários das antigas metalúrgicas. Atualmente, há uma rápida verticalização e valorização desses imóveis, em que as empresas estão construindo edifícios de médio e até de alto padrão, com apartamentos de dois, três ou quatro quartos, suítes, mais de uma vaga na garagem e uma diversidade de ofertas de conforto para atrair uma população de maior renda. ${ }^{123}$

Encontramos nas ruas próximas da CEAGESP um grande número de moradores de rua, que também circulam dentro da Companhia em busca de trabalho e alimento. No ano de 2002, a Secretaria da Assistência Social do Município organizou uma pesquisa que identificou um grande número de moradores de rua, cerca de 200 pessoas, dos quais 45 foram entrevistados, na época. A pesquisa indicou justamente a relação entre os moradores de rua e o Entreposto, pois esse pode oferecer alimentos e trabalho com menos dificuldade. Os homens predominam e possuem idade avançada, indicando os traços do perfil do grupo. Depois da pesquisa de diagnóstico, foram realizados debates com a comunidade da Vila Leopoldina, que

\footnotetext{
${ }^{121}$ Fonte: Plano Diretor Regional -diagnóstico - Plano Regional da Subprefeitura da Lapa - Quadro Situacional preliminar Lapa. 2003. Fundação para a Pesquisa Ambiental.

${ }_{122}^{12}$ Debate do Plano Diretor Regional

${ }^{123}$ SILVA (2006) faz desse debate em sua dissertação.
} 
demonstrava uma certa rejeição à proposta de implantação de um albergue na área. Essa discussão $^{124}$ ocorria no processo de debate ao Plano Diretor da Cidade. As resistências à instalação do albergue foram as mais diversas, desde o repúdio dos moradores e comerciantes da Vila Leopoldina que temiam a falta de segurança, a desvalorização de seus imóveis, até a dificuldade de alugar um imóvel que atendia às necessidades e aceitação do proprietário para esse fim.

Em 2003 a Prefeitura do Município de São Paulo implanta um albergue na Vila Leopoldina $^{125}$. As assistentes sociais da Subprefeitura da Lapa nos informaram que o albergue da Vila Leopoldina tem um alto atendimento de idosos na cidade, acima da média. Essa instituição é administrada por uma organização não governamental, no caso, o Instituto Rogacionista, que recebe o repasse de verba da Prefeitura. O albergue possui capacidade para abrigar 80 (oitenta) homens no período noturno e 120 pessoas para banho e higiene pessoal, almoço, orientação e documentação. Esses albergados se identificam, normalmente, como catadores de papel. Além do albergue, há um apoio da igreja Nossa Senhora de Lourdes ${ }^{126}$ que fornece há muito tempo um sopão no período da janta, para essas pessoas.

Dessa maneira, temos na paisagem das ruas do entorno da CEAGESP uma série de manifestações de mobilidade do trabalho que estão vinculadas à centralidade que o Terminal exerce. Para melhor compreender o processo de mobilidade, selecionamos estudar as atividades desenvolvidas na área interna desse Centro de Abastecimento.

\footnotetext{
${ }^{124}$ Em reunião, realizada dia treze de novembro de 2002, assisti a reação da comunidade frente a proposta da instalação do albergue, pois nesse período fui representante do Conselho de Transporte pela Subprefeitura da Lapa.

${ }^{125}$ Endereço: Avenida Imperatriz Leopoldina, 1335

${ }^{126}$ Endereço: Rua Bretania, Vila Leopoldina.
} 


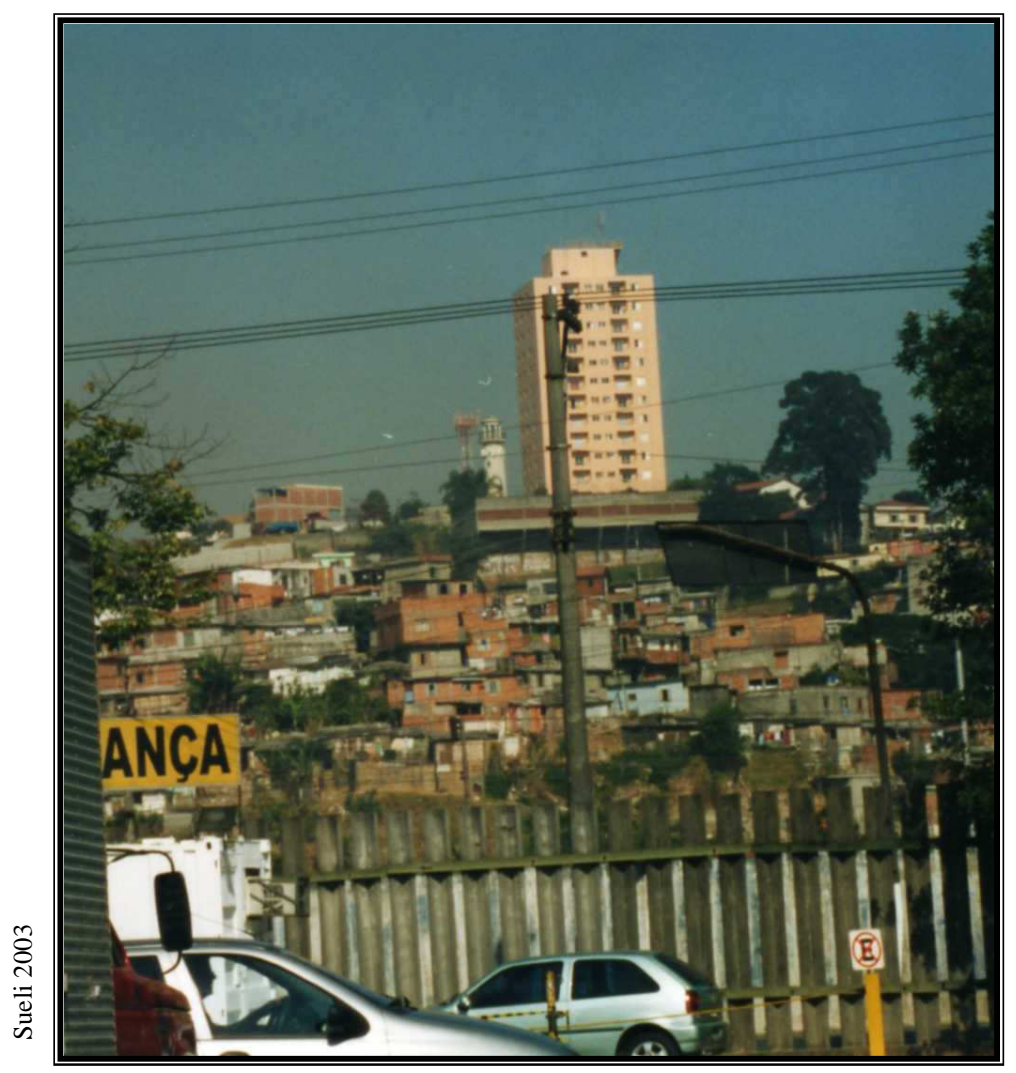

Foto 14: A Favela Nova Jaguaré vista a partir do Terminal da CEAGESP

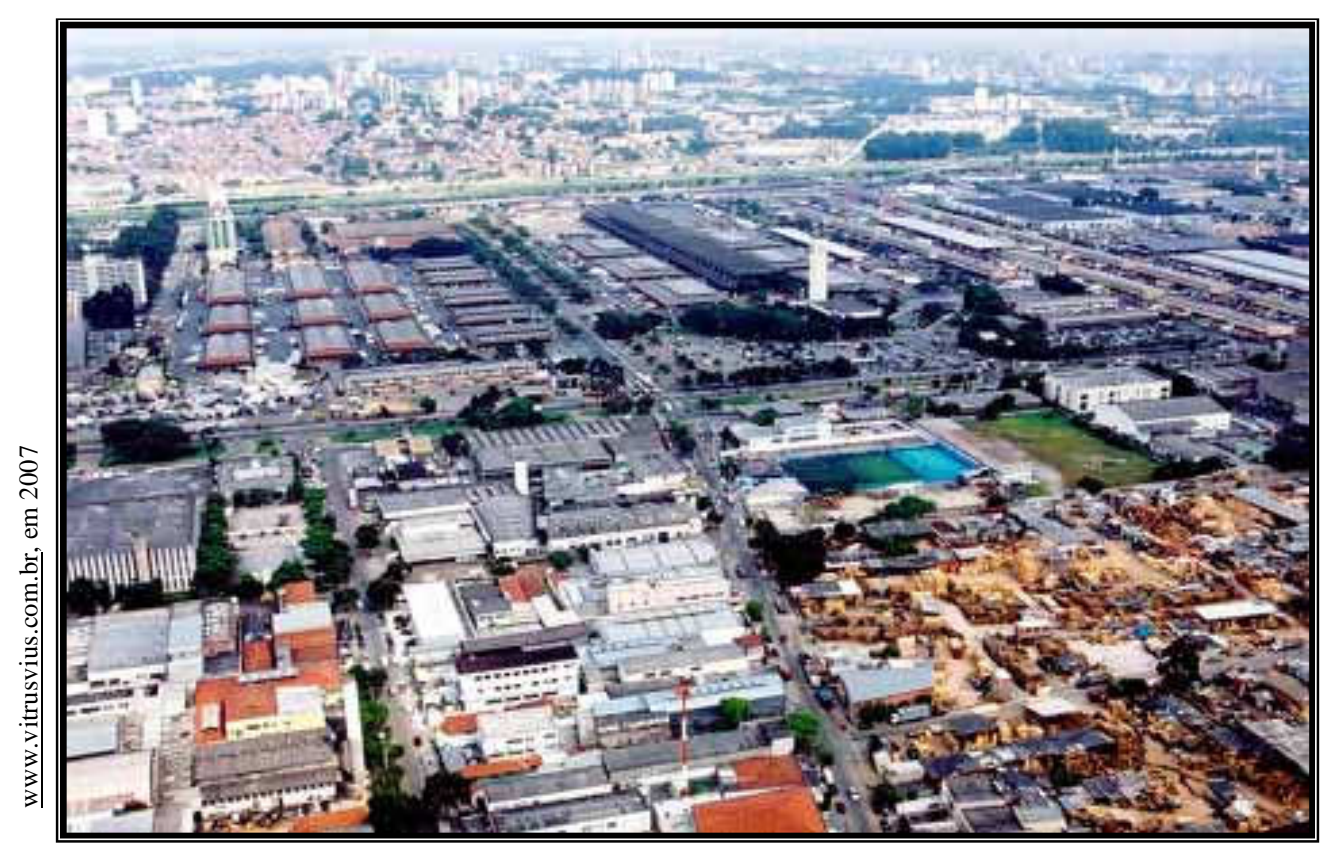

Foto 15: Vista Panorâmica da CEAGESP na parte central da foto; imagem a partir da Av. Imperatriz Leopoldina. No canto direito da foto pode ser ver o terreno ocupado pela Atividade e favela da Caixaria. 


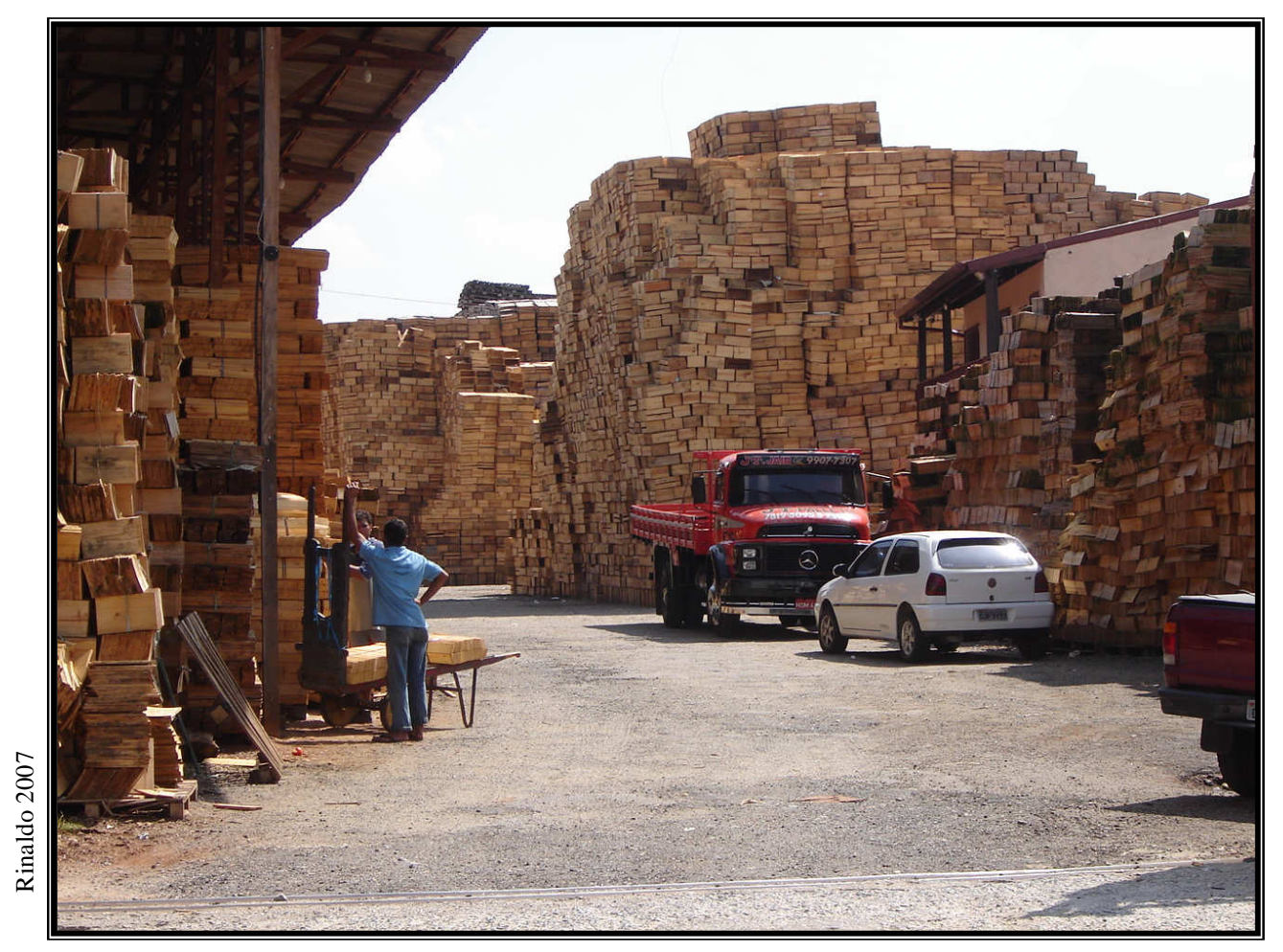

Foto 16: Imagem aproximada da Caixaria como atividade vinculada a CEAGESP presente no entorno da Central.

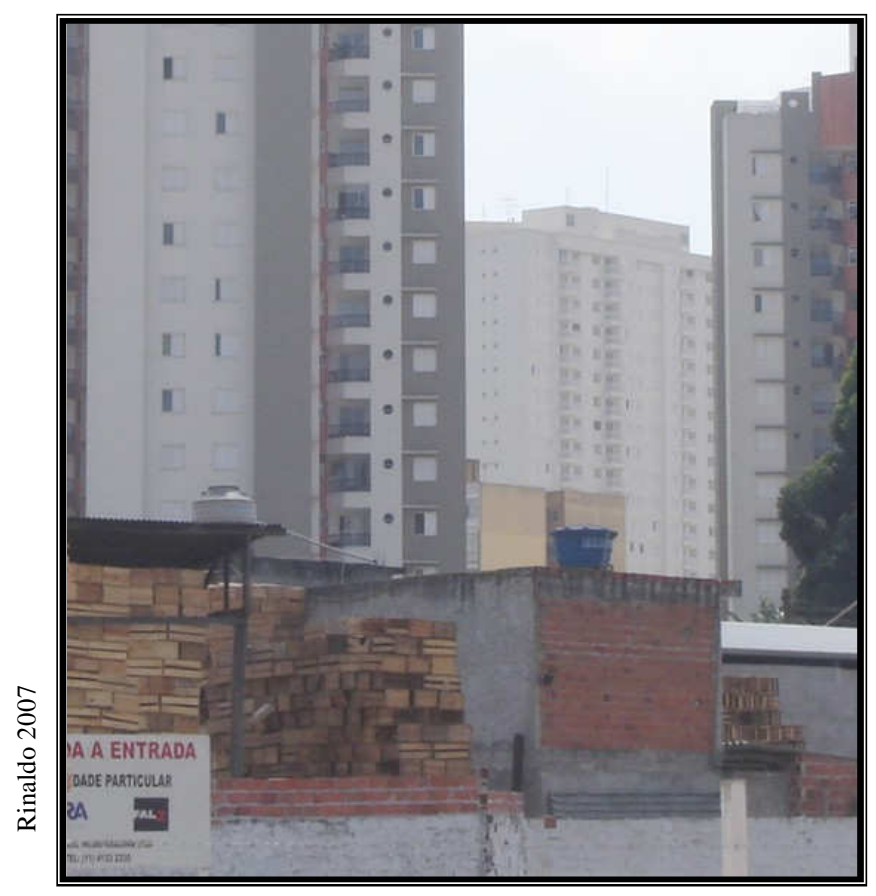

Foto 17 : A caixaria e a verticalização da Vila Leopoldina 


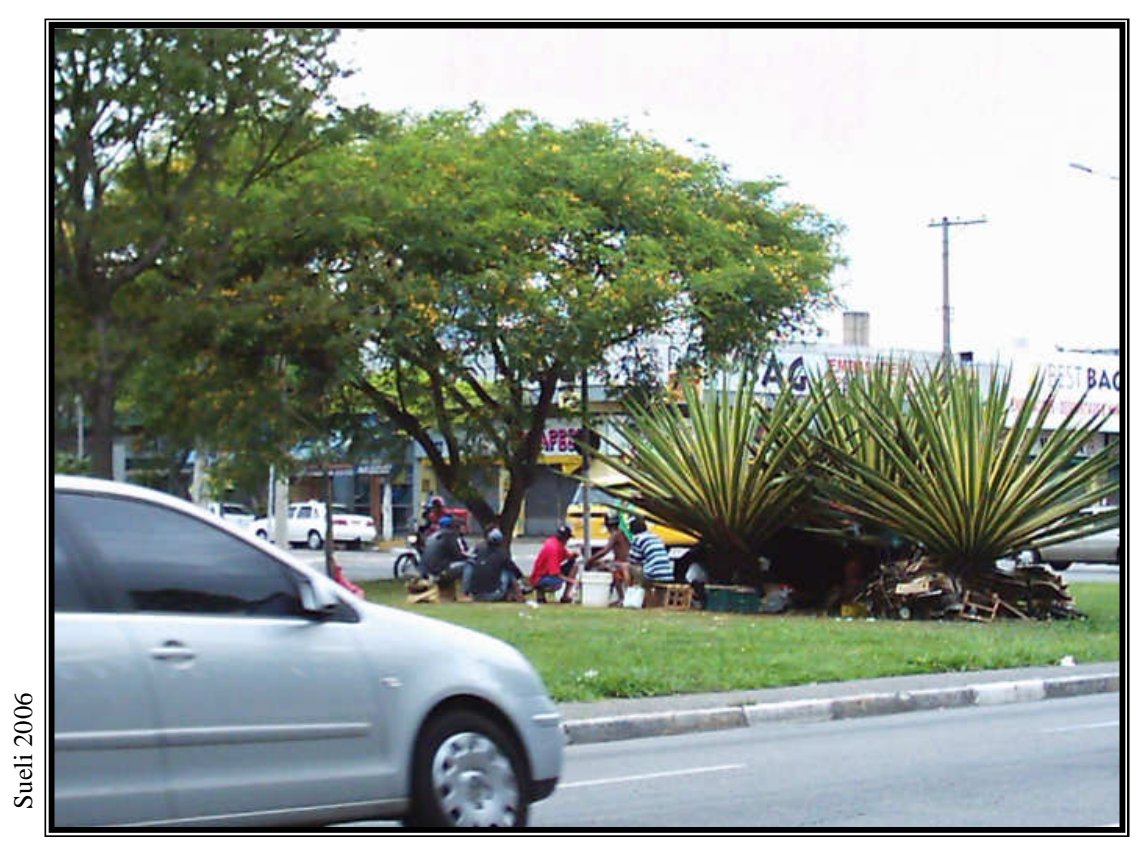

Foto 18: Moradores de Rua no canteiro central da Av. Gastão Vidigal

Foto 19: Pessoas que buscam alimentos no Terminal.
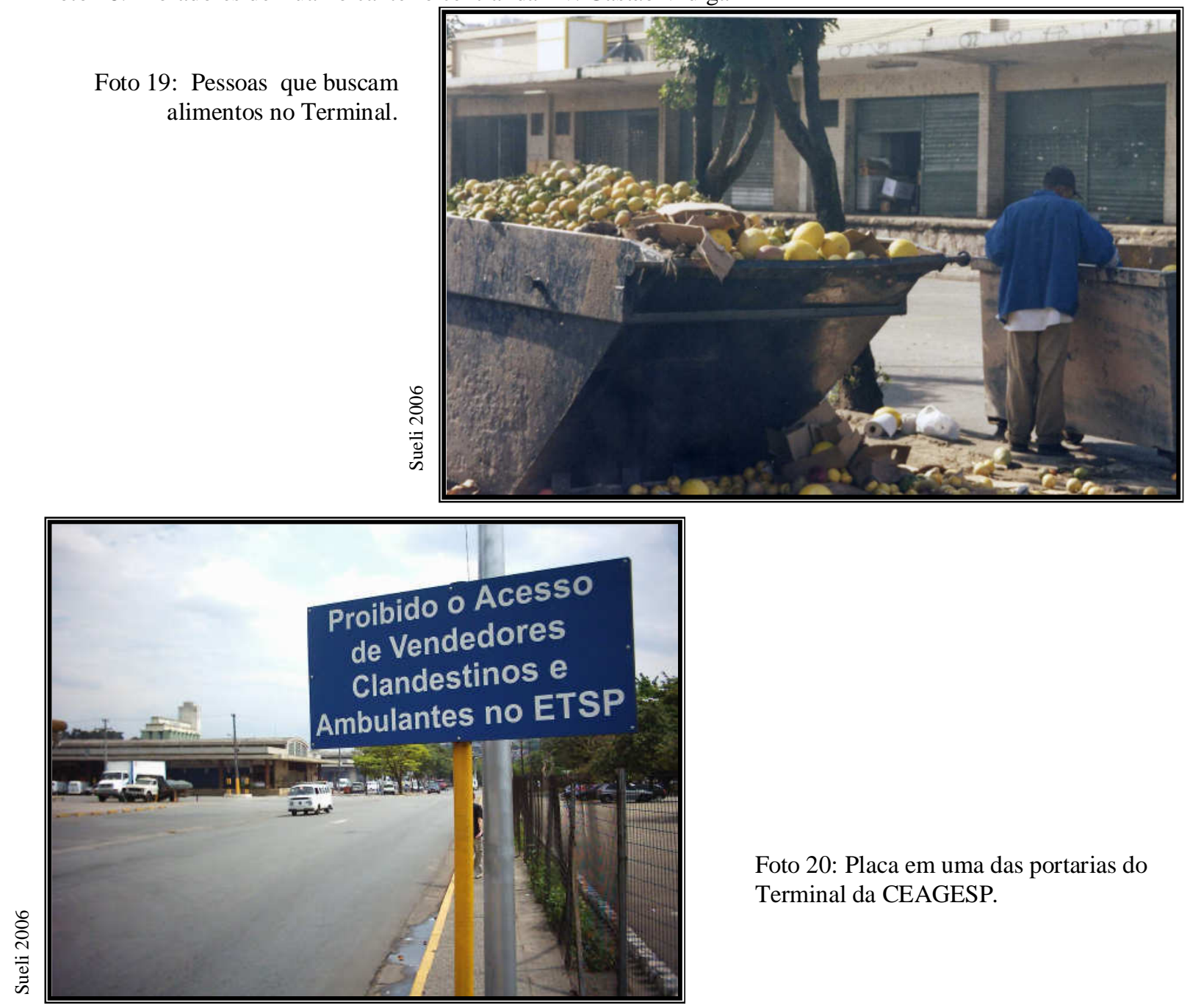

Foto 20: Placa em uma das portarias do Terminal da CEAGESP. 


\subsubsection{CEAGESP: mercado de trabalho}

Esse Terminal da CEAGESP normalmente é conhecido e estudado pelo seu papel principal, que é o abastecimento da metrópole e de outros espaços do território nacional. No entanto, pouco ou quase nada foi estudado a respeito das diversas formas de trabalho que existem nesse local, necessárias para viabilizar a circulação da mercadoria alimento. Portanto, procuramos revelar o papel de Mercado de Trabalho que o Terminal de Abastecimento da Vila Leopoldina (CEAGESP) representa. Vejamos alguns dados que obtivemos ao longo da pesquisa. Na leitura do Plano Diretor Regional da Subprefeitura da Lapa, no quadro situacional preliminar (2003) encontramos a seguinte afirmação:

Esta Subprefeitura ainda conta com um grande parque industrial que gera cerca de 200 mil empregos, sendo a maior oferta de postos de trabalho nas indústrias químicas e de produtos alimentícios, indústria mecânica, metalúrgica e de comunicação e editoração, mas, é no setor terciário, que há a maior oferta de empregos com cerca de $85 \%$, integrando esta oferta o $3^{\circ}$ comércio atacadista e produtos perecíveis do mundo (CEAGESP), cujo desempenho só fica atrás de Nova York e Paris." ${ }^{127}$

Em 1995 o SINCAESP (Sindicato dos Permissionários) encomendou uma pesquisa que mostrava os seguintes resultados: os permissionários ${ }^{128}$ geravam cerca de 18.000 empregos diretos apenas no ETSP (CEAGESP na Vila Leopoldina). Essa mesma pesquisa revelou que dos 1.672 permissionários pesquisados no ETSP, 64,7\% organizavam-se como empresas familiares. Nesse grupo de permissionários estudados, $62 \%$ dos que trabalhavam no ETSP também desenvolviam atividades ligadas ao setor agrícola, com destaque para os que comercializavam ovos $(100 \%)$ e flores $(90,6 \%) .{ }^{129}$ Além dos próprios permissionários, devese considerar a categoria dos seus funcionários. Existia, em 2001, aproximadamente 12 mil empregados das 3.800 empresas permissionárias ${ }^{130}$.

Há também os trabalhadores que circulam no espaço do Entreposto, como os caminhoneiros, que dirigem os 10 mil caminhões que circulam nesse local ${ }^{131}$, e os

\footnotetext{
${ }^{127}$ Plano Diretor - diagnóstico - Plano Regional da Subprefeitura da Lapa, Quadro Situacional preliminar Lapa. São Paulo:FUPAM. 2003.

${ }^{128}$ Número de permissionários: 3 800, porém o setor de comunicação estima 3000.

${ }^{129}$ Fonte: SILVEIRA, Nemo. Jornal EntrePosto, março de 2002.

${ }^{130}$ Fonte: Folha de São Paulo, 18 de novembro de 2001, caderno Dinheiro, pp. 3-4

${ }^{131}$ Fonte: Romero (2006). A imprensa divulgava, no ano de 2000, 5 mil caminhões. Não é permitida a entrada dos chapas, em acordo estabelecido entre a Companhia e o Sindicato dos Carregadores. Essa categoria foi estudada por Mezgraves (2006). Chapa de caminhão é o acompanhante do motorista que tem a função de descarregar o caminhão e também servir de guia na cidade de descarga e carga. Uma pesquisa sobre os Chapas de Caminhão registra uma entrevista, realizada em Ribeirão Preto, que o avô do chapa trabalhou de carregador na CEAGESP, depois o Pai e, hoje ele trabalha de Chapa de Caminhão. Esse depoimento reforça, que na
} 
compradores (feirantes, supermercados, restaurantes e distribuidores), que trabalham com a circulação dos alimentos e vão ao Terminal adquirir a mercadoria, para revendê-la em outro local.

Atualmente, existem na Administração da CEAGESP, trabalhando na Vila Leopoldina, aproximadamente 500 funcionários. ${ }^{132}$, entre operacionais e administrativos, que cuidam de gerir, alocar os módulos e os boxes, cadastrar, fiscalizar, gerenciar a manutenção e a limpeza. Navarro (1992) investigou a política do Departamento Pessoal da Companhia em relação aos recursos humanos, à política salarial, ao treinamento e ao sistema de avaliação e desempenho. Observamos no plano operacional e administrativo a diversidade de profissionais, divididos em classes nas quais se inserem desde técnicos e universitários até cargos de menor exigência de qualificação. Essa investigação, quando relacionada à graduação do curso de Assistente Social, constatou que a Companhia criou o cargo de Serviço Social em 1978, voltado para os funcionários e seus dependentes, bem como a presença da ABRECE (Associação Beneficente e Recreativa dos empregados da CEAGESP). Essa associação tem um cunho assistencial, beneficente e financeiro voltado para os funcionários. Além dos funcionários regulares, há também empresas terceirizadas, que contratam os trabalhadores da limpeza e segurança ${ }^{133}$. No período entre os anos 70, 80 e início de 90 identificamos que a Assistência Social, restrita aos funcionários, assim como a Associação, ignorou determinados problemas sociais, como: trabalho infantil, prostituição, moradores de rua e outros trabalhadores da área interna da Companhia.

Existem trabalhadores ligados aos serviços já mencionados, como agências bancárias, correio, padaria, dentistas e lanchonetes, que também alocam espaços e são considerados permissionários. Outras formas de trabalho se fazem necessárias no terminal, como a exercida pelos trabalhadores da Escola Nossa Turma.

Há uma série de formas de trabalho do circuito inferior que foram organizadas: ambulantes, cafezeiras e carregadores, que se denominam como trabalhadores autônomos, sendo reconhecidos e cadastrados pela administração da CEAGESP. Justamente essas formas de trabalho são as que buscamos estudar mais atenciosamente nesta pesquisa, além dos

CEAGESP não há chapas pois, "lá, o pessoal é contratado". Existe uma reserva de trabalho estabelecido pelo Sindicato.

${ }^{132}$ Fonte: Entrevista com Flávio Godas, chefe de seção de Economia e Desenvolvimento. Em julho de 2000 é publicado no jornal do entreposto, artigo sobre três dias de greve da categoria dos funcionários, por reajustes salariais. Naquela matéria, o presidente do SINDBAEST, Alemão, registra "á dez anos a companhia tinha 2500 funcionários dos quais 250 não trabalhavam. Ninguém abria a boca contra isso... deixasse de ser um cabide de empregos. Hoje, eu não considero que haja excesso de funcionários. Hoje, pode haver uma redistribuição de pessoal. A CEAGESP tem 750 trabalhadores na administração indireta, o que é pouco pelo tamanho da empresa."(julho de 2000, Jornal EntrePosto).

${ }^{133}$ A empresa responsável pela segurança é a Capital Seguros. 
trabalhadores que estão à margem do reconhecimento, em posição de clandestinidade e sempre na fuga da fiscalização. Dessa forma, encontramos trabalhadores que não compõem o circuito superior, mas tem uma "certa" regulamentação e os que estão no circuito inferior e estão "desregulamentados" e, portanto, fora do controle do Estado. Em geral, essas atividades são assumidas principalmente pelos migrantes sem ou nenhum recurso.

A mobilidade encontrada não se refere apenas ao deslocamento espacial, mas também à mudança social de alguns antigos carregadores e empregados que se tornaram atacadistas. Encontramos esse processo presente nos depoimentos sobre a história de trabalho na CEAGESP. Vejamos o depoimento de um taxista cearense, que desenvolve em suas simples palavras, essa mobilidade do trabalho: "Já vi muitos ficarem ricos e muitos quebrarem. Muita gente quebrou aqui, mais do que enriqueceu”. Ele relata que antigos comerciantes não existem mais; apenas a empresa que se mantém: "Pela família, não, mas pelos empregados que roubaram tudo. (risos) Tem um monte de empresa assim, aqui dentro. É sério". Nos trabalhos de campo pudemos identificar esse processo conversando com alguns permissionários.

Sobre os Atacadistas do Terminal, o Centro de Qualidade em Horticultura da Ceagesp, realizou em 2005 uma pesquisa, entrevistando-os para caracterizar o perfil desse permissionário. A partir de 108 entrevistas em diferentes pavilhões chegou-se a algumas conclusões: a metade deles está trabalhando no Terminal desde o seu início, pois foram deslocados do antigo Entreposto. Somados ao grupo que está há mais de 15 anos, formam um conjunto de $70 \%$, sendo assim a grande maioria dos atacadistas; o segundo grupo está no mercado entre 6 e 15 anos (40\%); e apenas 1,83\% estão a menos de um ano. Desses atacadistas a maioria não é produtor $(68,81 \%)$ e apenas 30,28\% é produtor agrícola, sendo que desses $4,59 \%$ comercializam somente a produção própria. A maioria indicou a inadimplência $(52,29 \%)$ como um dos maiores problemas que enfrentam no Entreposto, depois segue a insegurança $(10,09 \%)$, a falta de compradores $(4,58 \%)$ e a caixa vazia ${ }^{134}(3,67 \%)$.

Um indicador importante para mostrar como a CEAGESP é um mercado de trabalho são os sindicatos que tem sede instalada no Terminal da Vila Leopoldina. Vejamos: SINDCAR, SINCAESP (Sindicato dos Permissionários em Centrais de Abastecimento de Alimentos de São Paulo), SINDBAST (Sindicato dos Funcionários), APESP (Associação dos Permissionários do Entreposto de São Paulo), SINCOMFLORES ${ }^{135}$ (Sindicato do comércio

\footnotetext{
134 Caixas vazias são as caixas devolvidas pelo comprador ao atacadista, que atravancam o Mercado, atrapalhando a carga e a descarga, ocupando espaço.

135 A sede do sindicato saiu do Terminal, por inadimplência, recentemente.
} 
Atacadista de Flores e Plantas de São Paulo), ACAPESP (Associação dos Permissionários). Encontra-se aí também a sede da Associação das Cafezeiras.

A Seção de Economia da Administração da Companhia estima que, ao todo, o Entreposto gera cerca de 15 mil empregos diretos e indiretos. Nesse sentido, considerar o Terminal, também, como um Mercado de Trabalho é significativo. Entretanto, o que nos incomoda, é a redução dos números estimados de emprego. Antes a estimativa era de 18 mil empregos; hoje é de 15 mil, apesar da elevação da movimentação financeira, nesse mesmo período. Em relação a informações que tínhamos no início de 2000 sobre o cadastro de cafezeiras, ambulantes e carregadores, também ocorreram reduções sobre o número de empregos. Nesse sentido, partimos para estudar em particular uma dessas atividades, a dos carregadores, para entender melhor essa redução.

\subsection{A CEAGESP e a inserção do migrante}

No espaço interno à Companhia encontramos uma enorme rede social de migrantes nordestinos que se inseriram nas diferentes formas de trabalho, não regulamentado e regulamentado. A Companhia foi instalada em 1966 na Vila Leopoldina, período em que grandes levas de migrantes nordestinos chegavam em São Paulo à procura de um emprego. $\mathrm{Na}$ década de 70 houve uma grande expansão da atividade comercial e da ação da Companhia. Assim, as oportunidades de trabalho no Terminal eram fartas nesse momento e possibilitaram a inserção de um grande número de migrantes, entre eles os nordestinos. Assim, o Entreposto, conhecido pela sua dimensão no setor do abastecimento, também é um grande Mercado de Trabalho. Vejamos o depoimento:

\footnotetext{
Porque quando começou o CEASA... O CEASA já foi..., por que muitas pessoas falam - 'É o CEASA só tem nordestino' Não. Quem fez São Paulo foi nordestinos. Isso a pessoa devia entender, quando esses prédios feito em São Paulo, toda escada ali, era nordestino que carregava lata de concreto nas costas e de massa, não tinha elevador... Então, São Paulo foi construído pelo nordestino. E o CEASA, aí veio o CEASA, por causa das enchentes do $P q$ D. Pedro, fez aí o CEASA. Aí veio os cearenses que tinha lá, e os Piauiense, já subiram pro CEASA, aí... (Zé Pinheiro)
}

Nessa pesquisa elegemos os migrantes trabalhadores da CEAGESP, que contribuem no processo de circulação da mercadoria alimento, sendo que estudamos principalmente o trabalhador que se inseriu no circuito inferior, e sofre um processo de precarização, pois esse tende a crescer exponencialmente em tempos de crise. Essa diversidade de formas de trabalho, 
assumida pelos migrantes regulamentados, autônomos e precarizados foram ocupando as brechas do mercado de trabalho da CEAGESP, como: carregadores, cafezeiras, camelôs, "bate-ripas" que encaixotam as mercadorias antes de chegar aos boxes, prostitutas, bicheiros e matadores de aluguel. Entre a circulação de homens e mercadorias, selecionamos para esse estudo as atividades dos carregadores. Nas metrópoles, como a Grande São Paulo, o trabalhador migrante se associa basicamente à circulação, pois adquire plasticidade, mesmo que precariamente.

Identificamos algumas das atividades do circuito inferior que foram criadas pelos migrantes como uma estratégia de inserção no Entreposto. Os primeiros que chamam a atenção são os "bate-ripas". Cobram geralmente $\mathrm{R} \$ 0,10^{136}$ para embalar e fechar as caixas de frutas em uma caixa de madeira, pois é assim que elas precisam chegar aos boxes, antes de serem comercializadas. Cada batedor consegue fechar 900 caixas por dia, o que lhe dá um rendimento diário de $\mathrm{R} \$ 90,00$. Ao fim do dia, os dedos desses trabalhadores estão machucados. Por isso essa atividade é feita em dias alternados. Essa é uma tarefa árdua, que possibilita um trabalho para os migrantes que residem nas favelas entorno do entreposto.

Outra forma de inserção dos migrantes é como vendedores de sobras do dia. Ao final da tarde, eles catam as frutas do chão e as arrumam em caixas para revendê-las em bairros periféricos da cidade. Essa prática não é bem vista pelos comerciantes do entreposto, pois esses vendedores de sobras cobram pelas frutas a metade do preço. Assim, indiretamente, esses vendedores de sobras se transformam em seus concorrentes.

Há outros migrantes que moram no entorno do Terminal e que recolhem pedaços de madeira do chão e os reutilizam, construindo novas caixas, que serão vendidas para os comerciantes de flores.

Os negócios chamados "paralelos" crescem na área do Entreposto. Estimava-se que essa economia, invisível, que denominamos de circuito inferior, movimentava em 2001, por volta de R\$ 5 milhões, por dia ${ }^{137}$. Este era o mesmo movimento oficial daquele período. Se esta estimativa manteve-se até hoje, esses negócios paralelos poderão movimentar $\mathrm{R} \$ 9,5$ milhões por dia.

Existe uma fiscalização e um cadastro da Administração do Entreposto e dos Sindicatos de algumas dessas atividades. Entretanto, há uma quantidade desses trabalhadores que permanecem na irregularidade, pois o cadastro é limitado e além disso é necessário pagar uma taxa, o que reduz os seus ganhos. Lembrando que algumas atividades que estão no

\footnotetext{
${ }^{136}$ Fonte: Folha de São Paulo, 18 de novembro de 2001

${ }^{137}$ Folha de São Paulo, 18.11.01
} 
circuito inferior são ilícitas, como a prostituição, os jogos e outras práticas que discutiremos no final dessa pesquisa. Dados da imprensa de 2001 estimava por volta de 350 ambulantes não cadastrados, entre "cafezeiras", "pingueiras" 138 , vendedores de roupas, sapatos, tênis, relógios, etc. Existem 326 ambulantes cadastrados na Administração do Entreposto ${ }^{139}$, vejamos os dados desse cadastro:

Tab. 8: Número de ambulantes cadastrados

\begin{tabular}{|c|c|c|}
\hline Atividade (comércio e serviços): & 2001 & 2006 \\
\hline Café & 246 & 173 \\
\hline Lanches & 37 & 37 \\
\hline Salgados & 18 & 13 \\
\hline Sorvetes & 06 & 16 \\
\hline Doces & 06 & 09 \\
\hline Roupas e complementos & 08 & 09 \\
\hline Ferramentas & 04 & 05 \\
\hline Marmitex & 03 & 01 \\
\hline Bilhetes de loteria & 01 & 03 \\
\hline Mocotó & 01 & 01 \\
\hline Conserto de lonas & 01 & 01 \\
\hline Jornais velhos & 01 & -- \\
\hline Iogurte & 08 & 04 \\
\hline Água de Coco/Frutas & 12 & 09 \\
\hline Calçados & 03 & 0 \\
\hline MilhoVerde & 01 & 02 \\
\hline Caldo de Cana & ---- & 03 \\
\hline Frentistas & ---- & 17 \\
\hline Gelo & ---- & 09 \\
\hline Materiais Diversos & ---- & 07 \\
\hline Saúde & ---- & 01 \\
\hline Taxista & ---- & 16 \\
\hline Total: & 356 & 326 \\
\hline
\end{tabular}

Fonte: Folha de São Paulo (2001) e Administração do CEAGESP (2006)

Org.: Sueli de Castro Gomes

\footnotetext{
${ }^{138}$ Comércio de bebidas alcoólicas

${ }^{139}$ Os dados da Administração em anexo 17.
} 
Existe na tabela "Número de Ambulantes Cadastrados" ausência de informações, referentes ao ano de 2001, sobre algumas categorias, que foram consideradas pela administração da Companhia como ambulantes em 2006: taxistas, frentistas, vendedores de caldo de cana, de gelo, de materiais diversos, saúde. Houve uma redução no número de ambulantes ${ }^{140}$ cadastrados no Terminal, pois o cadastro está fechado há mais de dois anos.

Para ser cadastrado como ambulante é preciso apresentar uma relação de documentos (anexo 18), entre eles o cadastro na Prefeitura de São Paulo (lembrando que deve pagar uma taxa para o Município), a inscrição no INSS e o imposto sindical. Depois, paga-se uma taxa mensal para a Companhia, que varia conforme a atividade. A mais elevada é do marmitex, $\mathrm{R} \$$ 690,00 , a menor é do taxista $\mathrm{R} \$ 28,75$. As cafezeiras pagam $\mathrm{R} \$ 69,00$. Ficam isentos os deficientes físicos, os ambulantes com mais 60 anos e aqueles que estão no Terminal há mais de 5 anos ininterruptos. Existe, segundo as informações da administração, um número altíssimo de inadimplentes. Pelas normas, após dois meses de atraso no pagamento da taxa, o ambulante perde o direito de trabalhar no Terminal. Esses ambulantes devem ter um crachá e vestir um guarda-pó branco. Esse uniforme auxilia na diferenciação entre o camelô regulamentado e o não regulamentado. Assim, a presença do ambulante no Terminal é toda normatizada. Entretanto, no trabalho de campo, encontramos várias vezes cafezeiros clandestinos, servindo lanches e cafés, em sacolinhas. Quando visitamos o setor de fiscalização, observamos que é rotineira a apreensão desses trabalhadores que fogem do regulamento.

Entre a diversidade de formas de trabalho que encontramos na CEAGESP, a que mais nos chamou a atenção foi figura do carregador. Essa função foi sendo assumida pelos migrantes nordestinos recém chegados na cidade de São Paulo. Atividade cuja expansão foi determinada, principalmente, pelas redes sociais. Identificamos que uma grande parte dos carregadores da CEAGESP são migrantes oriundos do estado do Piauí. Em geral, eles residem na Grande São Paulo, em especial, no município de Osasco ${ }^{141}$.

\footnotetext{
${ }^{140}$ Teríamos que discutir o conceito de ambulante. Se considerarmos todas as atividades que não possuem ponto fixo, talvez pudéssemos considerá-lo como ambulante, mesmo assim, ele possui um espaço determinado para iniciar o seu trajeto. Assim, no nosso ponto de vista, não consideramos o taxista como um ambulante, mesmo porque o seu capital "automóvel" é bem diferente do capital necessário para os outros grupos.

${ }^{141}$ Esse deslocamento entre a periferia da metrópole e o CEAGESP é viabilizado por veículo particular, pelo serviço de transporte urbano e pela rede ferroviária, que se encontra próxima ao Entreposto.
} 


\section{OS CARREGADORES DO ENTREPOSTO: TERRITÓRIO DOS PIAUIENSES}

No Entreposto da CEAGESP podemos identificar uma diversidade de formas de trabalho nas quais os nordestinos, em São Paulo, puderam se inserir. Escolhemos estudar com mais acuidade a categoria dos carregadores, pois esta acabou sendo controlada por uma rede social de piauienses. Esta grande aglutinação nos despertou para a questão da rede social, de ser um dos mecanismos para determinar um dos diversos territórios que compõem a metrópole. Faz-se necessário o estudo desse território nordestino dentro da metrópole, em que tais trabalhadores se apropriam e controlam algumas formas de trabalho nesse Terminal de Abastecimento da Grande São Paulo. Eles formam esse território de trabalho, dentro de um espaço em que existem ainda múltiplos territórios que se imbricam. ${ }^{142}$

Para a compreendermos a formação desse território de trabalho de nordestinos estudaremos, assim, os carregadores no que diz respeito às suas relações de trabalho, à sua organização e aos aspectos referentes à sua mobilidade do trabalho, ao passo que os temas estritamente relacionados a rede social e territorialidade, serão melhor discutidos melhor no capítulo posterior.

\subsection{A caracterização dos trabalhadores}

Entre as flores, as frutas e os pescados encontram-se um exército de homens vestidos com jaleco (ou guarda-pó) de coloração única, pode ser cinza, laranja e branco dependendo do setor; eles estão sentados, conversam, observam, sozinhos ou em grupos em seus carrinhos numerados, apenas aguardando a sua vez, ou esperando que sejam chamados para o trabalho, assim como outros milhares de migrantes que aguardam os seus "gatos" para serem contratados... Eles passam também ligeiros, carregando frutas, legumes, verduras, peixes e até flores e plantas ornamentais; são responsáveis por transportar ali os alimentos que abastecem boa parte das mesas da metrópole paulistana, assim como uma parcela do território nacional. Eles são os carregadores da CEAGESP.

\footnotetext{
${ }^{142}$ Encontramos essa reflexão em HAESBAEST (2005). O autor estudou o território gaúcho em sua tese de Doutorado (1995) .
} 
Os carregadores do Terminal da Vila Leopoldina compõem um universo de três mil quatrocentos e cinco (3405) trabalhadores cadastrados na Administração ${ }^{143}$. Esses trabalhadores autônomos, ou seja, que trabalham por conta própria são regulamentados, e identificados, nessa condição, por seus uniformes (guarda-pós), como também por seu número de registro. O uniforme de cor laranja é usado para atuar no Mercado das Flores; no Mercado do Peixe, no setor de Pescado, a coloração é branca; no restante do Entreposto o uniforme é cinza. Há carregadores que trabalham, também, como empregados nos boxes, mas os que estamos estudando são aqueles que se encontram na condição de autônomo.

Constam carregadores regularizados a partir de 18 anos e até mesmo, acima de 80 anos. Os dados do cadastro da Administração ${ }^{144}$ revelam melhor a faixa etária que predomina desse trabalhador. Os que registraram as suas datas de nascimento atingem $78 \%$ (2998 carregadores) do total de cadastrados. ${ }^{145}$ Dentre os que deram a informação, distinguimos três grupos: o primeiro considera os mais jovens, na faixa etária dos 18 aos 29 anos, com 429 carregadores, o que representa 14,2\% do total; o segundo grupo reúne os de 30 a 59 anos de idade, que são 2261 trabalhadores, 78\% da categoria; o terceiro grupo, com carregadores acima de 60 anos, constituí 7,8\% do grupo, ou seja, são 234 homens ainda na ativa. Assim, constatamos a pequena participação e inserção dos jovens nessa atividade, o que nos indica, somando as entrevistas, a sua saturação e a menor absorção destes nessa função. Há um acentuado decréscimo de participação do subgrupo 46-50 anos de idade em diante. Sendo que quanto mais velho, há uma redução leve de sua participação, conforme demonstra o gráfico seguinte e as tabelas construídas (tabelas: faixa etária e idade, anexos n²0 e 21). Segue o gráfico 3, em que agrupamos os carregadores por faixa etária, em intervalos de 5 em 5 anos, a partir dos dados do cadastro dos carregadores na Administração.

\footnotetext{
${ }^{143}$ Dados de junho de 2006. Além dos cadastrados, há também, uma pequena parte dos carregadores que exercem a atividade de forma irregular, portanto, sempre devemos considerar que o universo é maior do que o número oficial.

${ }^{144} \mathrm{O}$ carregador é cadastrado pela CEAGESP, para tal ele deve preencher uma ficha (Anexo 19) com seus dados pessoais e uma série de informações como data de nascimento, origem (Estado e Município), estado civil, número de filhos, escolaridade, residência (município e distrito) que nos serviu como fonte para traçar um perfil desse trabalhador. De um total de 3405 carregadores, 417 não informaram ou preencheram incorretamente o espaço reservado para informar a data de nascimento (participação de $12 \%$ do universo total). Esses dados foram transformados na variável idade e organizados em uma nova tabela sobre faixa etária, nas que se encontra em anexo (20 e 21).

${ }^{145}$ Nesse universo, 417 carregadores não informaram ou informaram incorretamente a data de nascimento.
} 
Gráfico 3

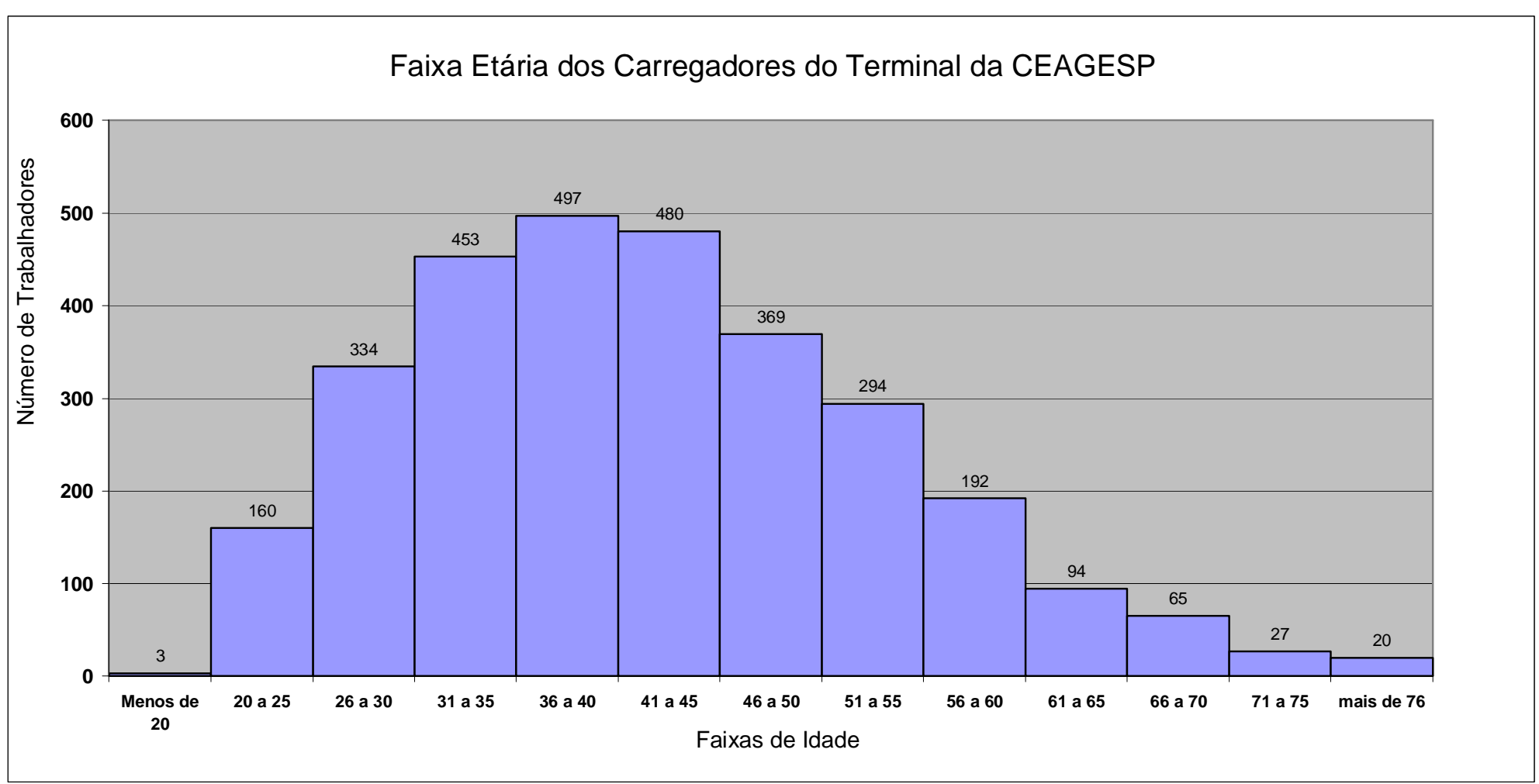

Fonte: CEAGESP (2006) e Org. : Sueli de Castro Gomes 
Outro dado significativo é a participação dos carregadores acima dos 60 anos, que representam 7,8\% da categoria (234 trabalhadores). Apesar do esforço físico que a atividade exige, esses trabalhadores que podem ser classificados como idosos, ainda, se mantêm ativos. Essa situação revela a precarização das condições dadas a eles. Recentes pesquisas mostram a grande ocorrência de uma migração de retorno dos nordestinos, entretanto, devemos pensar também nos que permaneceram na metrópole, e envelhecem e trabalham nesse espaço. Esses carregadores fazem parte daqueles migrantes que chegaram na cidade nas décadas de 50, 60 e 70, que se inseriram na CEAGESP e continuam até hoje. Poucos se aposentaram, já que a maioria não pagava a taxa de contribuição da seguridade social com regularidade e precisa continuar trabalhando. Mesmo aqueles que contribuíram com o INSS ${ }^{146}$ (Instituto Nacional de Seguro Social - Previdência), pagavam apenas o valor de um Salário Mínimo ${ }^{147}$, como autônomo. Essas contribuições acabam resultando em aposentadorias insuficientes para a manutenção daqueles idosos, que necessariamente precisam continuar trabalhando até enquanto suportarem as exigências da atividade ou o limite de uma enfermidade. Um destes casos é o Sr. Leonildes, que trabalhou até os seus $85 \operatorname{anos}^{148}$; outro, Sr. Wenceslau, com 81 anos, que está aposentado e mesmo assim, trabalha nas flores e na portaria do Sindcar. São homens que apresentam boa disposição física, apesar de suas idades avançadas. Encontramos os carregadores mais velhos concentrados na Feira das Flores, pois o peso dessa mercadoria é menor do que em outros setores do mercado.

Existe um acordo entre a CEAGESP e o Sindicato para que seja priorizado a atividade de carregador no setor das Flores para aqueles que possuem mais de 55 anos ou alguma enfermidade que limite o seu esforço físico. Há um número limitado de vagas de carregadores para o Mercado das Flores, em torno de 500, controlado pela Companhia, e também um número de cadastro separado para atuar em tal espaço. Como o setor das Flores é mais rentável e exige menos esforço físico do trabalhador, acaba sendo a solução encontrada para diminuir as agruras da atividade para os carregadores mais velhos.

Como já era esperado, numa atividade que exige maior esforço físico do que intelectual, a pesquisa revelou um baixo nível de escolaridade entre os carregadores. Os dados cadastrais $^{149}$ dos trabalhadores mostram um perfil de escolaridade no qual $12 \%$ deles são

\footnotetext{
${ }^{146}$ A Administração da CEAGESP exige a comprovação do último pagamento do INSS, para a renovação do recadastramento.

${ }^{147}$ Valor do Salário Mínimo em Agosto de 2006 era próximo de R\$ 350,00.

${ }^{148}$ Ele se aposentou da atividade de carregador na CEAGESP, em 2005.

${ }^{149} \mathrm{O}$ entendimento do nível de qualificação desse trabalhador foi obtido a partir dos dados cadastrais cedidos pela Administração da Companhia. Dos 3405, apenas 23 deles não informaram. As fichas do cadastro foram preenchidas por eles e no campo reservado à escolaridade solicita-se o grau de instrução (ver anexo a ficha 19). O vocabulário utilizado para expressar era diverso: No grupo de analfabetos reunimos as seguintes categorias:
} 
analfabetos, 5\% completaram o ciclo básico ou apenas iniciaram. Constam ainda os que não completaram o Ensino Fundamental, grupo predominante, 68\% do total, o que caracteriza a baixa escolaridade que a atividade exige para absorver esses trabalhadores. Entretanto, 9\% dos carregadores têm o Ensino Fundamental Completo, 2\% o Ensino Médio Incompleto, e $3 \%$ têm o Ensino Médio Completo. Alguns carregadores (5 trabalhadores) têm ainda Ensino Superior completo e Incompleto, o que aponta uma precarização do mercado de trabalho e da educação, em que o trabalhador com um grau de escolaridade elevado encontra-se inserido em atividades que exigem menos qualificação. Ver o gráfico a seguir (Anexo 22: Tabela de Escolaridade)

não alfabetizada, nenhum, e analfabeto; o ciclo básico nós agrupamos tanto o completo quanto o incompleto, em que apareceram todas as séries do ciclo e a expressão que corresponde ao antigo primário. O Ensino Fundamental corresponde ao antigo Primeiro Grau, aqui. O Ensino Médio corresponde ao antigo Segundo Grau ou o Colegial. Tanto no nível do Ensino Fundamental quanto no Médio foram registradas as séries em que o trabalhador deixou de estudar. Essas séries foram agrupadas nos níveis adotados. 


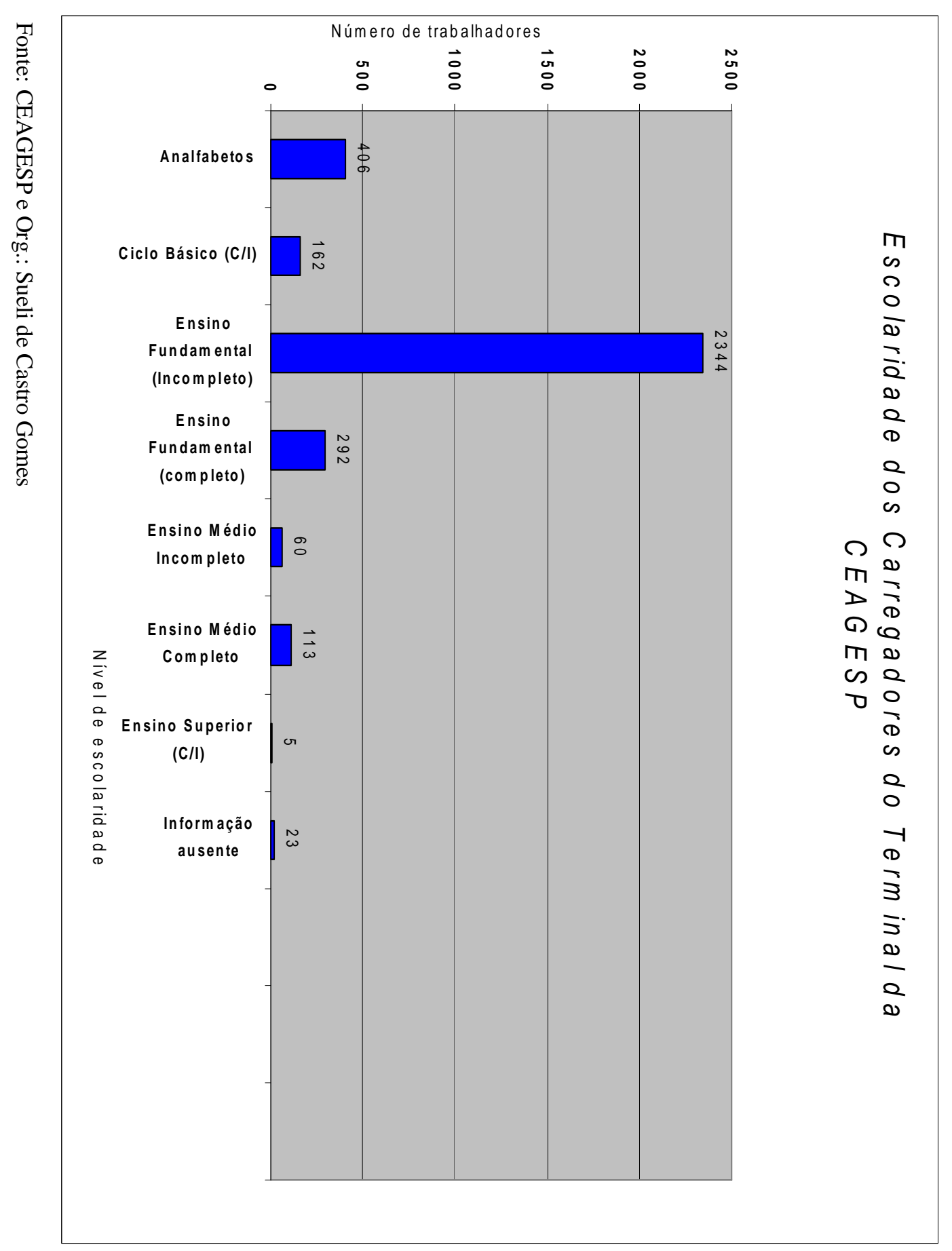

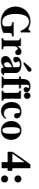


Os carregadores, que se designam como autônomos, ganham pela quantidade de carretos que fazem. Seus depoimentos registram que nos anos 70 e 80 os carregadores conseguiram comprar casa própria e carro zero; mostram, também, que alguns puderam comprar propriedade na área de origem, e que outros possuem chácara nas proximidades da metrópole, ou então são proprietários de boxes. Já a maioria dos carregadores que se inseriram depois dos anos 90 não possui o mesmo pecúlio pois a partir desse período, seus rendimentos caem vertiginosamente. Alguns carregadores que aproveitaram os ganhos do período do Plano Real conseguiram adquirir algum pecúlio, como o grupo de ex-carregadores piauienses que se tornaram atacadistas, o que aponta uma outra faceta da mobilidade do trabalho.

Há um acordo entre o Sindicato e a CEAGESP que determina o preço das "viagens" segundo uma tabela. Esse ajuste deveria possibilitar a manutenção do rendimento de tais trabalhadores. Mas com o agravamento da crise econômica, na década de 90, esse tabelamento perde a sua referência e as negociações, muitas vezes, passaram a ser individuais, entre carregadores e comerciantes. Em 2001, segundo a imprensa escrita, um trabalhador podia ganhar $\mathrm{R} \$ 30,00$ por dia, ou até menos, dependendo de seu ponto de trabalho (Pescados, Frutas, Flores). Vejamos o que diz o jornal: "Com um rendimento mensal que chega a $\mathrm{R} \$ 2000,00$ os carregadores autônomos do CEAGESP trabalham cerca de 12 horas por dia." 150

No entanto, nosso trabalho de campo indicou rendimentos bem menores que o publicado pela imprensa escrita. Houve dias em que pudemos observar carregadores que não tinham conseguido fazer sequer uma "viagem", que nem tinham ganho o suficiente para pagar o seu transporte até a sua residência. Outros carregadores contam que há períodos em que três desses carregadores dividem um só marmitex para se alimentar. No verão, o setor de frutas oferece mais oportunidades de serviço, e no inverno essas oportunidades migram para o setor da batata, cebola e diversos. De modo geral, no Terminal, há períodos de alta, em que se pode conseguir mais de um salário mínimo por dia, como no fim do ano. Assim, o rendimento maior do fim do ano serve para cobrir o período do inverno, em que os rendimentos são menores. Vejamos o gráfico que mostra o volume comercializado em toneladas nos anos de 2005 e 2006, distribuído pelos meses do ano (Anexo 23 - Tabela de dados da CEAGESP). Nesse gráfico podemos distinguir o período do ano que aumenta o volume em toneladas comercializado, assim aumentando a oportunidade de serviço para os carregadores. Segue o gráfico:

\footnotetext{
${ }^{150}$ Fonte: Folha de São Paulo, 18.11.01.
} 


\section{Gráfico 5}

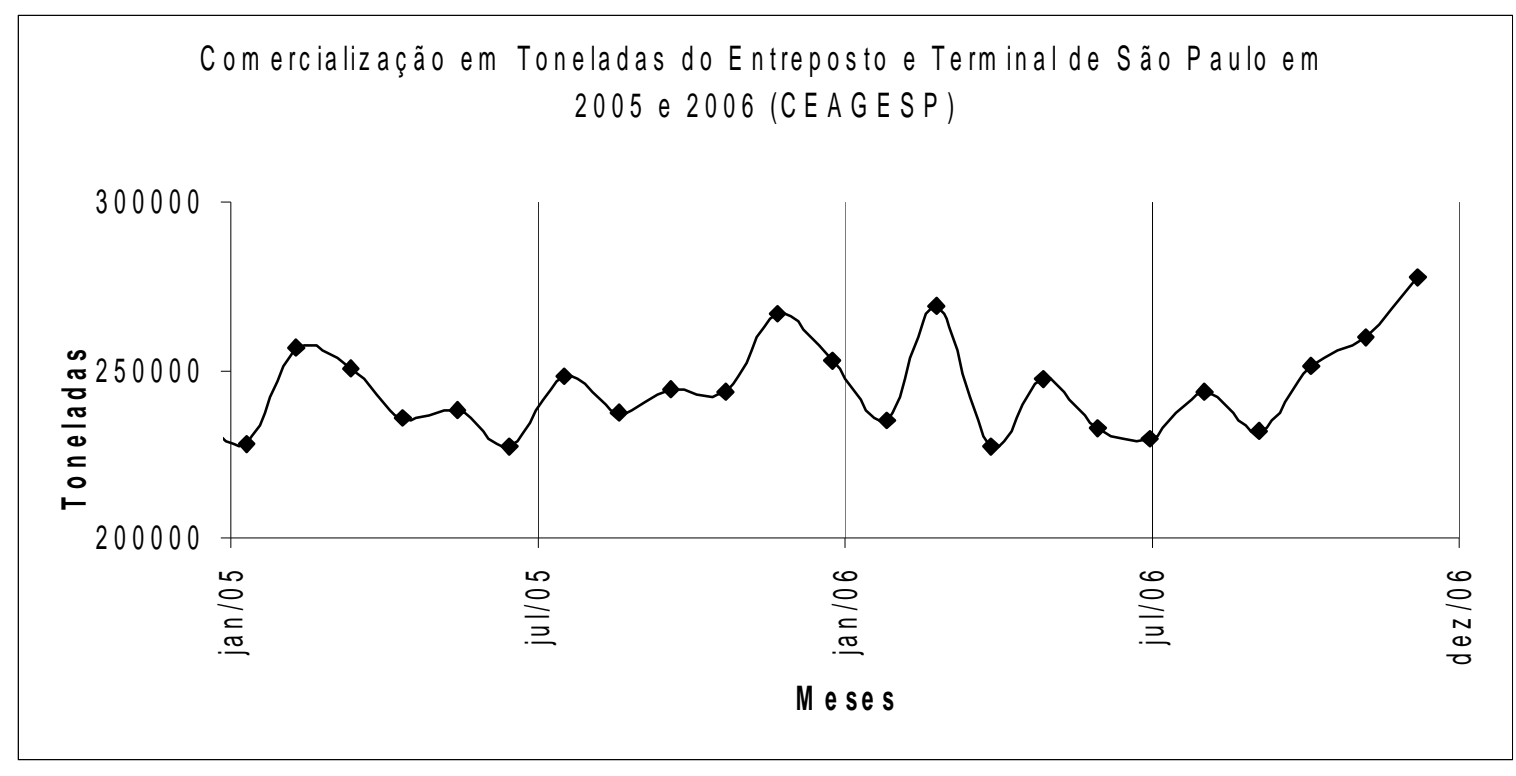

Org.: Sueli de Castro Gomes e Ary de A. R.odrigues Jr.

Fonte: CEAGESP (2007)

$\mathrm{Na}$ avaliação de alguns, são poucos os que conseguem um rendimento de $\mathrm{R} \$ 2000,00$. Estima-se de fato que muito poucos carregadores conseguem ter esse ganho, a média de rendimento gira entorno de dois salários mínimos, ${ }^{151}$ se considerarmos os custos que o trabalho autônomo tem que arcar, esses rendimentos são baixos. O fragmento abaixo é de uma entrevista a um carregador e pode nos indicar com mais clareza os rendimentos:

Olha só, vou te falar uma coisa. Tem muitos que tira esse salário, mas digamos assim, dez por cento. Se sabe, que em tudo que é setor, se trabalha em uma firma, tem aqueles que tem, os chefões, os encarregados. Eles tem um salário mais alto. Aqui é o seguinte, depende muito da sorte, a pessoa tem um serviço que dá pra tirar isso aí; mas... com certeza, porque eu te falo, é mais ou menos dez por cento, tira esse salário $(R \$ 2.000,00)$. Tem muitos que chega a tirar até um pouquinho a mais. Mas tem muitos que fica ali na faixa de $R \$ 600,00, R \$ 700,00$. Essa é a média. (Zé Francisco).

Vejamos a fala de carregador no mercado das flores, local que possibilita um rendimento maior:

Fiz apenas dois carretos. Tem dia que chego às 5:00 da manhã, fico até às 10:00 e não tiro nem $R \$ 160,00$. Atualmente, o ganho não paga o aluguel. Sendo que no passado, ganhava-se muito, há dez anos. (Eduardo).

Os comerciantes acabam pechinchando na hora de contratar, o que barateia o preço da mão de obra. O desemprego que atingiu a metrópole teve reflexos foi sentido no Terminal de

${ }^{151}$ Salário Mínimo:R $\$ 350,00$. 
Abastecimento, pois ampliou o número de carregadores disponíveis e a atividade ficou saturada. A quantidade de carregadores é maior do que a capacidade de sua absorção e a necessidade da circulação de mercadoria. Se antes, na tabela, a caixa carregada valia $\mathrm{R} \$ 0,50$, já em 2001 o serviço passou a custar $\mathrm{R} \$ 0,25$, e havia quem fizasse por $\mathrm{R} \$ 0,18 .{ }^{152}$ No fim de 2006, a caixa carregada vale $\mathrm{R} \$ 0,29$, e o carregamento ou descarregamento de um caminhão tinha um preço fechado, conforme a tabela do Sindicato. No setor geral, o carregamento de um caminhão variava entre $R \$ 200,00$ e $R \$ 250,00$, indo até $R \$ 400,00$ para uma carreta. $\mathrm{Na}$ feira de flores eram cobrados $\mathrm{R} \$ 10,00^{153}$ para o transporte das mercadorias adquiridas pelos compradores. Se no passado a tabela definia $\mathrm{R} \$ 15,00$ pelo carreto, o quadro instalado impôs uma redução nesse valor, diminuindo os ganhos. Muitos recordam dos tempos áureos e reclamam da crise que se instalou. Ocorrem períodos em que o rendimento é melhor, pois há uma maior circulação de produtos. $\mathrm{O}$ período de maior movimento começa em novembro e vai até abril, depois há uma queda no volume da comercialização e, portanto, acontece a diminuição dos rendimentos dos trabalhadores.

No setor do pescado, cada caixa transportada custa $\mathrm{R} \$ 1,00 .{ }^{154} \mathrm{O}$ Sr. Geraldo conta que em alguns dias chega a carregar apenas duas caixas - "Agente vê o que pode fazêe". Os mais jovens chegam a levar 30 caixas em uma "viagem", mesmo o limite de peso sendo 20 caixas; isso acontece quando tem serviço. O período em que os rendimentos são maiores no setor do pescado é a época da sardinha, que se inicia no fim de fevereiro e vai até a Páscoa; nesses meses os carregadores de outros setores (frutas, verduras, batatas, flores) trabalham também no pescado. Alguns dos depoentes não conseguiam estimar quantas viagens faziam por dia, pois a quantidade variava muito naquele período. Outros carregadores responderam que, na média, eles faziam umas cinco ou seis viagens. O rendimento dos carregadores mais novos na atividade parece ser menor se comparado aos carregadores mais antigos. Vejamos essa fala "Sempre [se] leva alguma coisa devido o conhecimento que a gente têm, é difícil ficar sem fazer nada em alguns dias” (Heleno) Esse carregador, paraibano, está desde 1987 trabalhando no setor do pescado. Quando ele se refere à expressão conhecimento, que é muito utilizada por eles, significa o poder do contato e da informação para obter serviço e realizar mais viagens, ampliando os rendimentos.

Acompanhamos durante o período da pesquisa (2003-2006) carregadores que estavam "desistindo" de trabalhar na CEAGESP nessa função, mas continuavam a buscar ali outras

\footnotetext{
${ }^{152}$ Fonte: Folha de São Paulo, 18.11.01.

${ }^{153}$ Fonte: Trabalho de Campo, outubro de 2006. Samuel conta que nas terças-feiras consegue fazer 5 ou 6 viagens e nas sextas-feiras, umas 12 viagens.

154 Janeiro de 2007.
} 
formas de trabalho: vendendo doces ou outro tipo de mercadoria, sempre em torno da Companhia. Segundo um funcionário da Companhia, no cadastramento constata-se menos de $1 \%$ de desistência, sendo assim, é fato muito difícil ocorrer, desprezível.

Com o processo de modernização e o desemprego, houve um aumento, já dissemos, do número de pessoas na função de carregador, muito mais do que o necessário. Elevou-se a concorrência entre eles e, conseqüentemente, seus ganhos diminuíram. Segundo a afirmação de um trabalhador - "Existem mais carregadores do que consumidores". Outro problema que os preocupa é a implantação de máquinas empilhadeiras, que podem substituí-los, levando-os a se juntar ao "exército" de desempregados.

A maioria dos carregadores têm seu próprio carrinho, que pode ser adquirido nas oficinas. O valor de um carrinho está em torno de $\mathrm{R} \$ 500,00$, além do custo de sua manutenção. Há uma minoria que aluga o carrinho no início da atividade, até adquirir o seu próprio. ${ }^{155}$ Um carrinho que recebe a manutenção pode durar até 15 anos. Os carregadores autônomos são identificados pelos carrinhos cinzas, enquanto os funcionários dos permissionários se utilizam de carrinhos amarelos.

Além disso, o carregador autônomo deve adquirir o uniforme, que pode ser comprado no Sindicato ou de uma pessoa autorizada pela Companhia. Ele paga ainda uma taxa mensal de $\mathrm{R} \$ 6,00$ de filiação ao Sindicato, além de uma taxa anual para a CEAGESP, de $\mathrm{R} \$ 15,00$; também, há taxas para a Prefeitura (ISS), para se trabalhar como autônomo. Paga-se, também, o valor mensal de $\mathrm{R} \$ 12,00$ para que o carrinho fique guardado no Galpão. Há, além disso tudo, despesas com a renovação do cadastro (exame médico, taxa anual de contribuição sindical $^{156}$, INSS). Então a contribuição mensal para a previdência social é a última a ser sanada no cômputo das despesas mensais dos carregadores, estando na maior parte em atraso.

Vale lembrar também que quando o carregador derruba uma mercadoria e esta é danificada, a responsabilidade é toda do carregador, que arca com essas despesas. As péssimas condições do asfalto, repleto de buracos, e a má conservação das áreas em que eles circulam acarreta constantes acidentes no transporte dos alimentos.

Vejamos o depoimento de um dos carregadores sobre a inserção nessa atividade:

Pra te falar a verdade, o serviço aqui é o seguinte, conforme vai pegando conhecimento, você não fica mais sem serviço, porque... isso depende muito do conhecimento. Olha! Pra quem entra hoje, que não tem muito conhecimento, arruma serviço, mas não é muito fácil. Aí, já sente um pouquinho de dificuldade. Outra, também, pra entrar aqui, não é muito

\footnotetext{
${ }^{155}$ Os carrinhos têm o número do registro geral e a cor de acordo com o setor: amarelo (flores), cinza (geral).

${ }^{156} \mathrm{O}$ valor da taxa sindical é de $\mathrm{R} \$ 105,00$,
} 
fácil, porque tem que ter um certo capital para desembolsar prá tirar documentação, que a gente trabalha assim autônomo, então tem que ter um certo capital. (Zé Francisco).

Dessa maneira, para começar na atividade de carregador, deve-se sempre ter um pequeno capital, para arcar com as taxas do cadastramento, uniforme e, principalmente, adquirir ou alugar o carrinho, nas oficinas. Encontramos, também, uma terceira situação, muito comum: são os empréstimos do conterrâneo, feirante, ou a troca por trabalho até ele ter seu próprio carrinho, revelando um outro significado da rede social.

\subsection{O trabalho por conta própria e os seus limites}

Apesar de todas as dificuldades, ainda é uma atividade de inserção relativamente fácil. Pois, essa condição exige pouca escolaridade e muitos preferem a condição de autônomo, já que os rendimentos são maiores do que os dos carregadores assalariados, que trabalhando para os permissionários, ganham um salário mínimo. As entrevistas com carregadores apontam que manter um empregado assalariado, como carregador dos boxes, saí muito mais barato para o atacadista do que o contrato com carregadores por conta-própria.

Esses trabalhadores autônomos começam a ter os seus primeiros desafios, no cadastramento em que encontram exigências para poderem se inserir nessa atividade. Vejamos o que é necessário para o carregador poder se cadastrar, quais as características de seu trabalho, as suas jornadas, as condições e dificuldades que enfrentam no exercício dessa profissão.

O depoimento do Sr. Mateus, carregador que já trabalhava no antigo centro de abastecimento (Entreposto e Mercado Municipal), relata que lá, os carregadores trabalhavam na rua. Somente o chamado chapa podia entrar no Mercado Municipal, enquanto os carregadores, não tinham essa permissão, nos anos 60: "Não tinha esse negócio [cadastramento]... se entrava o fiscal, nós 'saia'. Na rua não era clandestino. Aí nós viemô [para a Vila Leopoldina]”.

O Sr. Mario Benassi, um dos permissionários mais antigos do Terminal conta que só ele indicou para cadastrar mais de 200 carregadores, vejamos o seu relato:

Vamos supor, as pessoas vinham e começavam a trabalhar, o carregador trabalha comigo, dai vinha um parente dele,: ' - Olha Mario, arruma...', Então, eu ligava para o gerente do mercado, que era meu amigo e falava:Olha! Credencia fulano, que é gente boa. Então, dava indicação. Com a indicação era mais fácil. Na época tinha um sargento, sempre arrumava 
documento pros carregadores, cobrava 50 reais, dinheiro de hoje, por exemplo, de cada carregador pra credenciar, sendo que era de graça e os coitadinhos iam lá, precisam de indicação, iam lá, ele falava que arrumava, então, eu indicava de graça. (Benassi).

Nesse depoimento podemos identificar como foi a inserção desse grupo de nordestinos que buscavam trabalho na Companhia no período militar, em que vemos um dos escalões dos militares tirar proveito dessa relação.

As entrevistas com o funcionário do cadastro e com os carregadores apontam que desde o início do Terminal havia uma preocupação com o controle e o cadastramento desses trabalhadores. Houve uma pequena diminuição de carregadores, mas, o cadastramento nunca fechou. Na média, desde o fím dos anos 80, se mantém o número de 3.400 carregadores, segundo informações dos funcionários da Companhia. Atualmente, há uma limitação das vagas para que não ocorra uma ampliação na quantidade de carregadores além da necessidade do Entreposto. Existe um acordo entre o Sindicato e a Companhia, segundo o qual deve entrar o mesmo número de carregadores, que o número de cancelamentos. Assim, cada cancelamento possibilita a outro carregador cadastrar-se. Não existe um período reservado para o balanço da situação do cadastro, mas em geral, ele ocorre no meio do ano. O tempo de espera para conseguir o cadastramento varia muito, vejamos o depoimento de um piauiense que está na espera:

A maioria dos que conseguiu teve gente que passou muito tempo, teve um primo meu que passou mais de um ano, quase um ano e meio esperando. Já pra outros, eu não vou nem falar [...] que trabalha aqui, teve um que passou só um mês, dois meses, três meses, seis meses [...] depende da sorte da pessoa, também. (Anônimo).

Segundo os relatos, no fim da década de 60 iniciaram cerca de 200 a 300 carregadores no Entreposto. No início dos anos 80 , havia 2.500 carregadores $^{157}$, na virada da década, houve uma expansão da atividade devido à maior circulação de mercadoria na década de 90 . Vejamos o relato:

[...] porque quem era carregador não dava para trabalhar. Ele trabalhava 24 horas e não conseguia atender o público que era de em torno de 75 mil pessoas por dia, isso aqui não se andava na sexta- feira, não tinha movimento, 'parava' as marginais, era uma época que os mercados não tinham a sua produção própria nesse período[...]. (Sr. Raimundo).

\footnotetext{
${ }^{157}$ Fonte: entrevista realizada em outubro de 2006 com funcionário da Companhia.
} 
Sobre a data de entrada dos atuais carregadores no Terminal obtivemos as seguintes informações - entre os 2987 carregadores que informaram sobre a data de início da sua entrada na CEAGESP, isto é $78,8 \%$, do universo da categoria. ${ }^{158}$ Dos carregadores que estão na ativa hoje, apenas 2,6\% estão no Terminal desde sua abertura; $16,1 \%$ começaram na década de 70; já 22,7\% entraram na Companhia na década de 80; a maior participação está naqueles que iniciaram na década de 90 , com $36,1 \%$. Após o ano $2000^{159}$ encontramos uma participação menor, com $22,4 \%$ dos carregadores. ${ }^{160}$ Esses dados vão ao encontro dos relatos que mostram que a maior ampliação do número de carregadores ocorreu dos anos 80 em diante.

Para o carregador se cadastrar, este tem que apresentar uma série de documentos, como atestados de antecedentes criminais emitidos pelo D.E.I.C (Delegacia de Investigações sobre o Crime Organizado), comprovante de INSS (Instituto Nacional de Serviço Social), comprovante de ISS (Imposto Sobre Serviço) - esse documento pode ser providenciado na Prefeitura de São Paulo ou retirado no Sindicato - , 3 fotos $3 \times 4$ recentes, exames médicos recentes, 2 fotocópias (xerox) de RG e CIC, título de eleitor e comprovante de votação, comprovante de residência, contato de uma pessoa (amigo, parente, irmão) que seja credenciado, ponto de referência do endereço. Os carregadores acabam contratando o serviço particular de um despachante, que não é do Sindicato, para organizar essa documentação, principalmente em relação ao ISS, em que há particularidades. O cadastramento é renovado anualmente e exigem os exames médicos recentes ${ }^{161}$, taxa sindical, taxa do ministério do trabalho (INSS). Toda essa documentação gera custos, a que se soma ainda a necessidade de ter um carrinho ou alugá-lo.

Depois de cadastrado, ele recebe um número. Esse número do cadastro é chamado de chapa e deve constar no uniforme e no carrinho, de forma visível, assim como na carteirinha, documento oficial de sua regulamentação.

$\mathrm{O}$ cadastramento divide os carregadores em dois grupos. $\mathrm{O}$ primeiro, que abrange $\mathrm{o}$ maior grupo de carregadores, é aquele dos que trabalham no setor geral. Esse grupo pode trabalhar em qualquer ponto do Terminal, com exceção do setor das flores, sem um ponto

\footnotetext{
158 Do total de carregadores, apenas de 418 não obtivemos a informação correta, o que significa $12,3 \%$ do universo estudado. Ver as tabelas geradas (Anexo 24 e 25).

159 Conforme a entrevista com o funcionário do cadastro é insignificante o número de desistências ou cancelamentos. Assim, novas inserções dos carregadores são mais difíceis. Apenas de 22,4\% dos carregadores cadastraram-se depois de 2000.

${ }^{160}$ Em 2005 não havia nenhum registro, descobrimos, no entanto, uma outra fonte impressa do cadastro que trazia e completava essa lacuna de informação. Segundo entrevista, em 2005, entraram 145 novos carregadores e, em 2006, um número menor do que o anterior, porém não foi possível contabilizá-lo.

161 Os exames médicos exigidos são exame de sangue, urina, fezes, próstata.
} 
fixo. O segundo grupo é justamente o do setor das flores, que possui um outro controle e uma outra numeração.

Normalmente, o carregador já possui um cliente fixo, que pode ser um permissionário, feirante ou um mercado. Então, já tem estabelecidos os dias, horários, mercadorias, por muitos anos. O baiano Zé Francisco trabalha para o mesmo feirante há 24 anos. Já Zé Cândido, piauiense de Inhuma, não teve a mesma sorte, trabalhou para o mesmo feirante 13 anos e então, ele encerrou a atividade; vejamos a sua declaração:

Às vezes o carregador consegue trabalhar com um único feirante, durante anos e às vezes trabalha com três, e às vezes fecham. Nesse caso arruma outro.

Um carregador que trabalha para o mesmo feirante já tem uma lista de determinados produtos e a quantidade que deve carregar até o caminhão. Então, o caminhão permanece fixo em uma das plataformas e cabe ao carregador ir buscar as mercadorias que podem ser as mais diversificadas frutas ou legumes. Quando a encomenda está mais distante, como no setor da batata e proximidades, o caminhão se desloca até lá e o carregador também. De modo geral, a tarefa funciona assim, tendo pequenas mudanças de contrato para contrato, na relação entre o comprador e o carregador. Muitas vezes, vemos um carregador com um papel na mão, lendo a lista das encomendas para a atividade que se realiza. A quantidade de carregadores analfabetos $^{162}$ não impede a tarefa de leitura do pedido para executar o transporte. Primeiro, vai o feirante, ou qualquer outro comprador nos boxes ou nas pedras, e faz a negociação. Geralmente ocorre no mesmo atacadista; isso não muda muito. Depois, o comprador deixa a lista das mercadorias que pegando as caixas vazias tipo " $\mathrm{K}$ " no caminhão, irá buscar essas mercadorias nos atacadistas, retornando com elas ao caminhão do comprador, para carregá-lo. De vez em quando acontece algum problema, como relata o piauiense Jessé:

... às vezes ele manda você troca, se vai lá trocar, ... eles mandam outra fruta diferente, [...] e faz um carreto [...] Ele manda devolver. [...] Negócio de devolver fruta. As vezes, é a hora mais chata de trabalhar:" fulano mandou a fruta errada" [...] se fica no meio... Aí você fica com medo de ser mandado embora ou o cara mandar a fruta errada de novo, e achar que você não tá servindo pra trabalhar pra ele. (Jessé)

Geralmente, os caminhões carregados com mercadorias destinadas aos boxes são descarregados pelos empregados do próprio box. Mas, ocasionalmente, o carregador autônomo é contratado para auxiliar nesse trabalho. O mais comum é encontrarmos o carregador trabalhando para carregar os produtos para o feirante ou supermercados. Para o

162 São 406 pessoas. 
permissionário de maior pecúlio é mais barato ter empregados para o trabalho de descarregar do que contratar um carregador autônomo. Para outros permissionários, o volume de comercialização não justifica ter funcionários para descarregar os caminhões, então esses contratam os autônomos.

O grupo de carregadores do setor geral muitas vezes trabalha em parceria ${ }^{163}$. Pudemos observá-los os carregadores em um fim de expediente e nos chamaram atenção os vários carregadores que chegavam com dois carrinhos no galpão do SINDCAR. Pudemos, assim, identificar um grupo que trabalha em sistema de parceria, até então invisível ao nosso olhar. A cena que assistíamos era de um dos parceiros carregando o carrinho do outro, que já havia partido. Geralmente, eles buscam alguém de confiança, que pode ser um conterrâneo, um parente ou mesmo um antigo conhecido do Terminal, pois para descarregar um caminhão é necessário o trabalho de mais de um homem, então, uma relação de parceria cria maiores possibilidades de trabalho. Nessa relação os ganhos são divididos por igual.

Há uma preferência para se trabalhar com supermercados do que com feirantes, pois o primeiro tipo de cliente oferece mais estabilidade e rentabilidade que o segundo. Os supermercados, em geral, pagam o carregamento do caminhão, o que é mais rentável, enquanto os feirantes, que diminuíram a quantidade de compras, pagam pelo serviço da viagem. Para encher o caminhão, contratam-se, normalmente, dois ou três carregadores.

No grupo do setor geral está incluso o setor do pescado, no entanto, observamos em trabalho de campo que seus carregadores têm as suas especificidades. Eles formam um grupo de 120 carregadores, que durante a alta temporada,a época o período da sardinha, chega a 200 homens. Eles trabalham nas madrugadas, enfrentando as baixas temperaturas do inverno e outras agruras do trabalho nesse setor. No Mercado do Peixe, os carregadores trabalham com os pés na água, então, como proteção, usam uma bota de borracha e meias. Vemos que as oportunidades no setor estão ainda mais reduzidas. Os carregadores do setor do pescado no Terminal atribuem essa redução do mercado do peixe à elevação de preços do pescado e à comercialização de peixe nas grandes redes de mercados. Os dados econômicos ${ }^{164}$ da Companhia apontam uma redução do mercado anualmente, diferente dos outros setores que crescem.

\footnotetext{
${ }^{163}$ Essa relação de parceria não foi encontrada no setor do pescado.

${ }^{164}$ Em 2005, houve uma retração do setor do pescado (-7,79\%), o que já havia ocorrido em 2004 (-7,49\%) [fonte: Jornal Entreposto, janeiro de 2006,a partir dos dados da Seção de Economia e Desenvolvimento da Companhia] Em artigo do Jornal Entreposto, julho de 2006, O presidente da Companhia, Francisco Cajueiro, afirma que, entre 1998 e 2005, houve uma redução de $40 \%$ no volume de pescados comercializados no entreposto da capital, passando de 67,15 mil para 40,93 toneladas por ano. $\mathrm{O}$ ano de 2006 apresentou uma ligeira melhora.
} 
Os carregadores do pescado transportam a mercadoria, basicamente, dos ambulantes, marreteiros, peixarias e turistas, pois os feirantes peixeiros trazem os seus empregados, identificados por carrinhos vermelhos.

Tinha dia que nós trabalhava até 8 horas da manhã, hoje quando é 5 horas, não tem mais; todo mundo procurando lavar o carrinho pra guardar; caiu muito. Pessoa levava 100 caixas, hoje tá levando 20. Os supermercados tira o serviço de um de outro. $O$ Carrefour mesmo colocou gente pra comprar pra eles, mas viram que não tava dando certo. [...] Tem firma que compra para o Pão de Açúcar, eles não contratam carregador [...] marreteiro que compra 5 caixas. (Antonio)

Vejamos o depoimento do carregador do pescado explicando como decorre sua atividade:

Se a senhora vem comprar e a senhora não conhece nada aí dentro, eu trabalho, a senhora me chama e aí eu vou dar uma dica: "Esse peixe aqui é tanto, esse aqui é tanto..." O que seria pra senhora levar, a senhora leva. Se senhora não quiser ficar entrando lá dentro, porque tem água, a senhora fica no seu carro. Manda eu ir comprar, eu compro e coloco no seu carro e a senhora vai embora. Aí dali, eu já sou carregador seu, já. Toda semana que a senhora vier, a senhora só chama eu. (Antonio).

Antonio, que já tem três clientes fixos, revela em sua fala que o trabalho do carregador vai além do simples transporte, ele se torna um guia, uma pessoa de confiança do comprador. O carregador do setor do pescado, além de transportar as caixas plásticas com os diferentes peixes e outros frutos do mar, deverá saber que o atum não pode ser transportado junto com as caixas, pois esse peixe é muito sensível e pode perder a qualidade totalmente, devendo ser transportado de maneira isolada. Vejamos o depoimento de outro carregador sobre o início de sua inserção:

No começo era meio difícil, porque não tinha treino, não tinha experiência, aí depois foi aprendendo e peguei prática... dava umas dicas, dava uma ajuda, explicava como é que é [...] aí eu não sabia, aí quando batia a caixa e caía peixe pra todo lado e machucava a mão, aí foi aprendendo, aí quando fiquei prático... (Raimundo).

Outro grupo de carregadores é o que trabalham no setor das flores que reúne 500 homens, que na maioria trabalham também no setor geral. O que muda nessa relação é o tipo de comprador que usa o serviço do carregador, que pode incluir donas-de-casa, paisagistas e as floriculturas, que segundo eles, são clientes mais "refinados". Esse trabalho ocorre às terças-feiras e sextas-feiras, a jornada começa nas madrugadas e termina às 10:00, podendo esse grupo conciliar a atividade com outras (trabalhar no setor geral ou outro trabalho fora da CEAGESP). Esse grupo pode obter maior renda, por essa característica dos horários, além de 
ser um trabalho menos desgastante do que o do grupo de carregadores do setor geral. Muitos deles já têm clientes fixos de muitos anos, estabelecendo relações de confiança e amizade, como conta o Carregador Joaquim:

A minha freguesa das flores pra mim é uma mãe. Tanto ela como o marido dela. Os meninos dela já tá com 15 anos o mais novo, o outro tá com 18, o outro tá com 17. Chama tudo de (tio)... 14 anos trabalhando pra ela. Eu vou aniversário na casa dela, passar o Reveillon na casa dela. Ela pra mim é uma mãe [...]. Eu chego e digo, '- Sonay', ela chama Sonay, a japonesa: “ Sonay eu tô precisando de dinheiro pra visitar a minha mã', -' Quanto? 'Não sei'. -'Você nem sabe quanto vai levar, dá quinhentos contos?'. Pra mim ela é uma mãe...não tem ônibus pra ir, aí ela diz: 'Você tem dinheiro?'. 'Tenho', 'Vai para o aeroporto comprar a passagem e eu vou te buscar no aeroporto.' Pra mim, ela é uma mãe, tanto ela me ajuda muito ... e o marido é um pai. Nas flores, nós tamô trabalhando lá, pára a cafezeira pra tomar um cafezinho, ela me dá um café...bolo [...].

A preferência pelo trabalho no setor das flores vai além da possibilidade do bom relacionamento entre eles e os compradores. A grande vantagem está no maior faturamento que eles podem obter, assim como o seu menor esforço físico, pois o mercado das flores ocorre no Pavilhão, local coberto que não possui plataformas e nem rampas, diferente da maior parte do Terminal. Para entender melhor, vejamos o que diz o carregador Samuel, quando relata seu trabalho em outros setores:

Porque para subir essas plataformas o carrinho tem que fazer uma força muito grande. Se imagina nessa chuva, pra subir, força que a gente faz, faz o dobro da força que você faz em linha reta, o dobro ou o triplo na subida, ajudando a carga, tem que pedir ajuda. (Samuel)

Eles carregam, diariamente, volumes de mercadorias dos consumidores da CEAGESP, que chegam a pesar de maneira excessiva, gerando problemas de saúde. Nos horários de pico, caminhar no centro de abastecimento é um desafio. É muito comum, as pessoas terem que desviar umas das outras, tal a quantidade de carregadores que vêm de todos os lados, ocorrendo, algumas vezes, acidentes ${ }^{165}$.

Outro problema apontado nos depoimentos é a exposição ao mau tempo, em dias de chuva ou de sol intenso. Como eles dizem “... com o sol na cabeça”. O trabalho ao ar livre e a exposição a temperaturas e condições climáticas diversas acarretam alguns problemas de saúde nos carregadores como nos relata Sr. Cândido que, uma vez, em 1978 ou 1979, trabalhava debaixo de uma chuva muito forte e resolvera enfrentar, depois disso teve uma gripe muito forte seguida por uma pneumonia.

\footnotetext{
${ }^{165} \mathrm{Um}$ dos carregadores conta que conheceu um garoto que perdeu uma perna, pois ele foi atropelado por um dos carrinhos que circula no ambiente.
} 
Um dos grandes problemas que os trabalhadores em geral enfrentam no Entreposto, e principalmente os trabalhadores da limpeza, é a grande quantidade de ratos e baratas atraídos pelos resíduos. Eles relatam determinadas situações de maior risco, como em um episódio de enchentes, quando se registraram casos de leptospirose entre os carregadores. Além disso, a circulação das motos, caminhões e outros veículos em alta velocidade, acaba causando acidentes e colocando o carregador em perigo. A velocidade máxima permitida varia entre 10 a $20 \mathrm{~km} / \mathrm{h}$, no entanto, os veículos trafegam algumas vezes a $60 \mathrm{~km} / \mathrm{h}$.

Ao compararmos os problemas de cada setor, identificamos no trabalho do carregador do setor de pescados a questão do mal-cheiro, que impregna na roupa e no seu carrinho, além da jornada que ocorre na madrugada. Já, as condições de trabalho no setor de verduras ficam visíveis nos uniformes, que ficam molhados ou sujos, pois se transportam caixas com lama, principalmente quando se carregam mandiocas, enquanto o carregador do setor da fruta é o que tem seus uniformes mais limpos. 


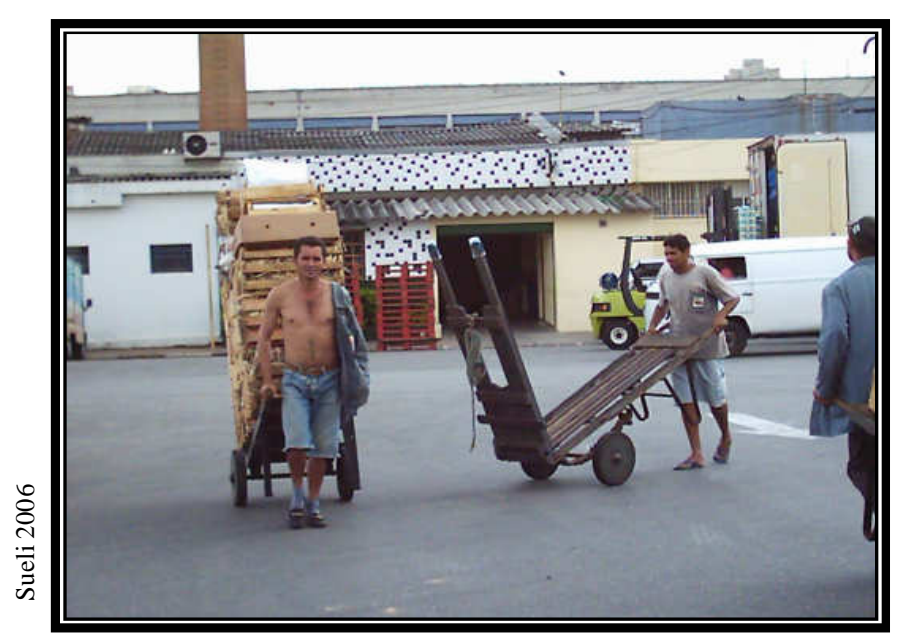

Foto 21: Carregadores do setor geral

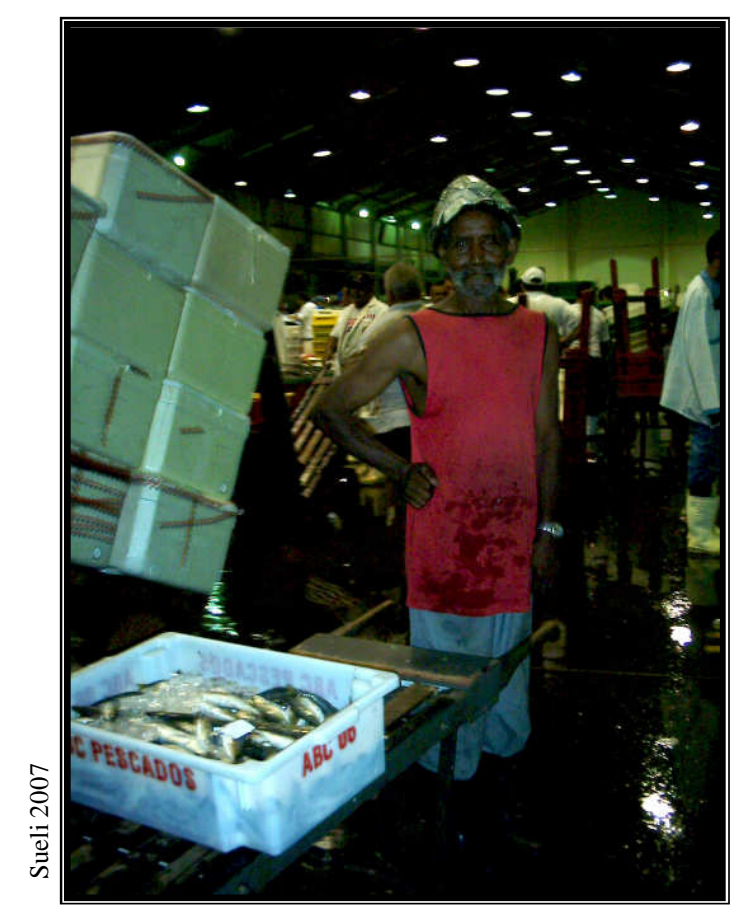

Foto 23: Sr. Geraldo, carregador do Pescado

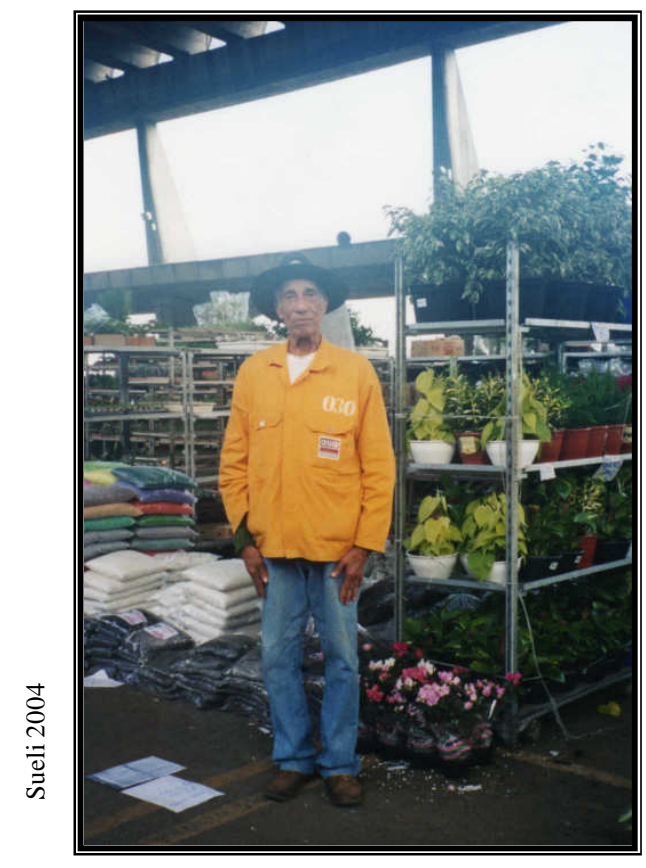

Foto 22: Sr. Leo, 83 anos, carregador do Mercado de Flores.

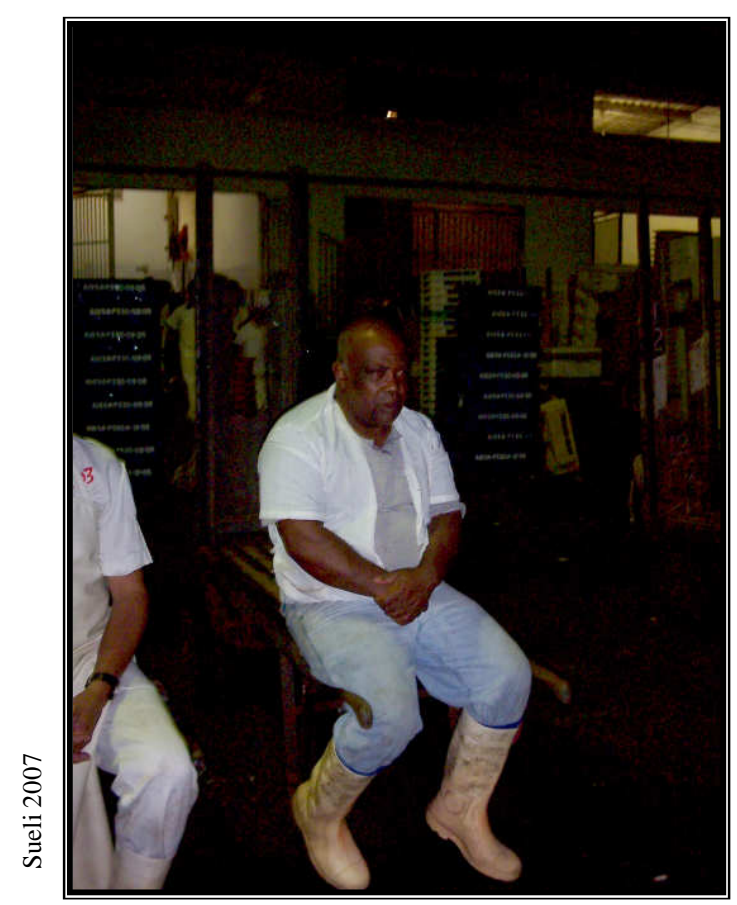

Foto 24: Sr. João, carregador do Pescado 
Uma parte dos trabalhadores almoça sentada em cima de seus carrinhos, com uma marmitex na mão que eles trazem de casa ou encomendam, outros comem nos quiosques instalados nas áreas internas do Entreposto. Caminhando pelo Terminal, às 10:30 da manhã, pode-se encontrar muitos deles já realizando a sua refeição pois começam a sua jornada muito cedo. Não há um horário fixo para comer as refeições, mas os relatos contam que havia, antigamente, muito mais carregadores que interrompiam as refeições no meio assim que aparecia um serviço e já iam transportar o peso da carga. Os carregadores que atuam nos setores das frutas, legumes e batata iniciam às 4:00 e continuam ao longo do dia, às vezes, cumprindo até 12 horas diárias ou mais. Eles chegam esse horário para ficar de plantão, porque dependem ainda da chegada do caminhão. O horário da saída dá-se com o do término do serviço de carregar o caminhão, que pode ir até às 20:00, ou mais. As jornadas variam, porém são estafantes para todos, já que seus rendimentos dependem de quanto carregam.

Edmar está há dezesseis anos no Entreposto, cumpre uma jornada que se inicia às 6:00 horas e se encerra às 20:00, para conseguir obter um mínimo de rendimento. Os depoimentos dos carregadores do setor geral indicam que essa jornada é a mais comum, contudo, as jornadas podem variar; há também aqueles que realizam essa jornada, porém intercalam dias de trabalho e de descanso, para agüentar o esforço da atividade. O carregador tem autonomia para cumprir as horas, mas os seus rendimentos dependem do seu trabalho, então, a tendência é que ele fique o maior tempo possível no Terminal, para realizar mais serviços. Como dissemos, não existe horário fixo, para a refeição, e mesmo férias e feriados, pois esse carregador vive do seu rendimento, se parar, não há um rendimento. Eles acompanham os horários e os dias de funcionamento do mercado, de segunda feira a sábado. ${ }^{166}$ Um carregador leva, no mínimo, duas horas para descarregar um caminhão, mas dependendo das mercadorias, esse tempo pode chegar a quatro ou cinco horas. Como afirma o presidente do Sindicato "Passa o dia e o cara nem vê." [...] "Passa mais horas aqui, do que em casa."(Zé Pinheiro). O espaço para o lazer e tempo-livre fica restrito, pois o tempo que tiram a 'folga' é reduzido. Eles declararam que no pouco tempo livre que têm, preferem mesmo ficar em casa para descansar. ${ }^{167}$

Vejamos o que diz um dos depoentes do setor do pescado sobre o seu horário de trabalho e o seu baixo rendimento:

\footnotetext{
166 Cada setor possui dias e horários determinados conforme a tabela de horários, que se encontra no capítulo dois. A jornada dos carregadores varia e segue a determinação de acordo com os horários de cada setor.

${ }^{167}$ As entrevistas apontaram que esses carregadores ficam nas suas casas no seu tempo livre, poucos indicaram o hábito de visitar parentes em São Paulo. No trabalho de campo, vimos cartazes anunciando espaços de forró e de apresentação de cantores nordestino fixados nesse local, assim como a divulgação de repentistas nas imediações.
} 
Serviço aqui pra nós é o que? Três ou quatro horas de serviço. Tem dia que você não trabalha nem uma hora de serviço. Abriu supermercado e ficou parado demais, o peixe ficou muito caro e devido o preço, e nem todo mundo gosta. (Heleno).

Os carregadores do setor do pescado começam a chegar no Entreposto por volta da meia-noite, por conta do horário da condução que pode ser o ônibus ou trem (que encerra à 1:00 hora da madrugada). $\mathrm{O}$ mercado do peixe só começa às 2:00 horas e encerra-se às 6:00 horas, de terça a sábado. Observamos em um dos trabalhos de campo alguns carregadores dormindo no galpão do SINDCAR e até do lado de fora, em cima de seu carrinho, que é usado como cama por eles. Esse fato está relacionado tanto ao limite do horário do transporte, bem como ao esforço do deslocamento para a sua residência, que aumentaria o desgaste.

Vejamos o caso de Sr. Mateos, de 68 anos, que trabalha em todos os setores pescado, flores, verduras, frutas: “

É bem dizer é 24 horas aqui dentro do CEASA... [...] dormia aqui dentro mesmo, no carrinho, a cama é gostosa. Tem lugar ali dentro mas eu não gosto.

Ele me explica que aproveita os intervalos para dormir; cita o caso de colegas que moram longe, até mesmo no interior de São Paulo ${ }^{168}$, e que acabam dormindo no Terminal, voltando para casa apenas nos finais de semana.

O Sindicato dos carregadores proporciona um atendimento médico, duas vezes por semana (segunda-feira e quinta-feira). Nas quartas-feiras, há um laboratório que coleta os exames na sede do Sindicato e cobra um preço abaixo da tabela para os não filiados e os seus filiados não pagam nada. No consultório médico ocorrem até 60 atendimentos em cada um dos dias, considerando os retornos. Segundo a Dra. Célia Medina, médica do Sindicato, as maiores queixas são sobre dores na coluna, justamente associado ao ofício de carregar excesso de peso. Vejamos sua observação:

Como é que pega um peso... a gente vê. Eles já tiveram aulas. Agora o que eles falam é que é muito difícil seguir isso por causa da velocidade da coisa, chega o caminhão, tem que descarregar ou carregar rápido, porque pra fazer direitinho, você gasta mais tempo. Dizem eles que é difícil, seguir direitinho. (Dra. Celia)

Um dos carregadores compara as mudanças ao longo do tempo e lembra que antigamente os caixotes eram mais pesados. Carregavam-se 100 ou 150 quilos e hoje a carga

\footnotetext{
${ }^{168}$ Como comprovamos nos dados do cadastro, aparecem cidades como Limeira e Campinas. Na verdade são apenas 10 carregadores que se encontram nessa circunstância.
} 
é muito mais leve. Essa geração que iniciou nos anos setenta, está apresentando problemas de saúde adquiridos que foram adquiridos ao longo dos anos.

Outra parcela dos carregadores apresenta pressão alta. A doutora atribui o problema aos hábitos alimentares dos carregadores. Sobre isso, ela diz:

[...]tem uma alimentação muito piauiense, deve ser, muita gordura, sal, a comida do brasileiro, quanto mais no interior, ela é mais tipicamente cheia de sal e gordura, e conclusão, você tem pressão alta, uma boa parte, tem pressão alta por causa da alimentação.

E o terceiro problema mais freqüente são as doenças associadas ao consumo do cigarro. Dessa forma, a médica faz um acompanhamento de quem está disposto a deixar de fumar e implanta uma medicina preventiva.

Tanto os cigarros como a hipertensão ocasionam doenças cardiovasculares, como o derrame e o ataque cardíaco. A médica relata que de dezembro de 2003 até julho de 2004 (7 meses), ocorreram três mortes por enfarto ou derrame na CEAGESP. Esse problema apareceu em alguns depoimentos:

Eu vi os caras se matar aqui, o cara pegou aí umas quatro baranga chegou aqui.[...] botou o carrinho no chão e foi bebe uma água ali, quando chegou que pegou aqui, empreteceu na hora, nem saiu do lugar. Empreteceu todo, agora de quê, eu não sei, acho que arrebentou todo. Os cara botou umas baranga dessas assim, e ele saiu se matando, ali, quando chegou ali, [...] (Sr. Leonildes)

Assim, explica a médica do sindicato:

O esforço físico, também, aumenta a pressão; a hipertensão, a nossa pressão sangüinea ela não... assim, o principal fator que sobe a pressão é alimentação, sal e gordura, excesso de peso. Mas outras condições, também elevam: stresse.Você tem que trabalhar com muita agitação, fazer muita coisa ao mesmo tempo que nem eles acabam fazendo, isto também, sobe um pouco a pressão e a própria força física, sobe um pouco a pressão, esse estado constante de uma rigidez muscular acaba fazendo também, uma rigidez na artéria e isso aumenta a pressão. (Dra. Célia) 
Para a médica, de maneira geral, os carregadores compõem, proporcionalmente, uma população até bem saudável, se considerarmos o esforço físico que a atividade exige. Além disso, ela complementa afirmando que eles são extremamente bem humorados, pois a atividade física estimula o aumento dos hormônios e das endorfinas no cérebro. Assim, a médica registra a satisfação de trabalhar com esses carregadores e com as cafezeiras, que também são atendidas no consultório. ${ }^{169}$

Porém as entrevistas revelam diversos problemas de saúde advindos daquela atividade; os mais velhos reclamam de problemas na coluna e recorrem a um massagista, instalado na área interna do Terminal. Vejamos o depoimento:

Hoje mesmo, eu fiz uma massagem, tem um rapaz, aí Pra quem trabalha com peso, isso sempre vai ter problemas de coluna, nervo ciático, varizes. Se você olhar nas pernas dos carregadores, quase todos têm problemas de varizes. Problema de joelho, estoura o joelho, dá problema no menisco. Porque é muito peso[...] (Zé Francisco)

O limite estabelecido para o carregamento de peso, segundo estudos ergonométricos realizados em 1983, é de 300 quilos, valor que equivale a 10 caixas de laranja ${ }^{170}$. No entanto, é muito comum caminharmos pelo Terminal e vermos esses trabalhadores carregarem até 20 caixas de fruta, ou de outro produto, transgredindo as normas que existem para a manutenção de sua saúde. A recusa desse esforço leva à perda do cliente, a um maior tempo para executar o serviço, e menor rendimento para ele e para o cliente; ou seja, maior tempo para a circulação da mercadoria e redução do lucro. Esse fato exemplifica muito claramente a reflexão que Gaudemar traz sobre a mobilidade do trabalho, em que chama a atenção para como os homens se submetem às exigências da ampliação do capital, disponibilizando os seus corpos a todo tipo de esforço, intensidade e ritmo.

Uma situação muito comum entre os carregadores autônomos, a falta de recolhimento da seguridade social, mesmo este sendo obrigado a apresentar um comprovante do INSS, no cadastramento e na renovação. Esse problema aparece diversas vezes, primeiro quando o indivíduo adoece e precisa de afastamento. Como são poucos os que pagam o INSS, a maioria fica sem poder entrar na caixa de benefícios.

\footnotetext{
${ }^{169}$ Precisamos fazer uma ponderação na explicação biologizante da médica, pois existem características culturais que demarcam o grupo de nordestinos, como o humor, que se manifesta mesmo com a dureza do trabalho. Talvez, seja o humor estimulado por esses estarem entre seus conterrâneos.

${ }^{170}$ Segundo o fiscal o limite máximo é de 14 caixas de frutas.
} 
O pessoal que tá afastado. O camarada, ele é autônomo, ele adoeceu, ele não tem renda nenhuma. INPS é poucos que pagam. [que pagam como autônomo]. Se todos pagassem INPS, quando adoecesse... mas, não é todos que pagam.(Zé Pinheiro)

Outra situação que encontramos que evidenciou o não pagamento da previdência social foi no caso da morte do carregador piauiense de Inhuma, 29 anos, por assassinato, no dia 12.10.06. A sua viúva, de 23 anos, com três filhos, estava requerendo a pensão junto à previdência, por isso ela estava solicitou ao setor do cadastro da CEAGESP os documentos que comprovassem a inscrição do falecido no INSS, porém não havia uma contribuição contínua e faltavam alguns meses para a viúva ter o direito à pensão. Essa prática é muito comum entre os carregadores, o pagamento do INSS acontece apenas nos períodos do cadastramento e do recadastramento. Nos outros meses não há recolhimento, dificultando, assim o acesso aos benefícios, já que exigem um mínimo de meses para dar direito à pensão ou outro benefício, como a aposentadoria ou afastamento por motivo de doença.

Em uma terceira situação que comprova essa prática, encontrarmos carregadores com mais de 60 anos, em idade de aposentadoria, que estão ainda na ativa. Daí percebe-se que não fizeram uma contribuição contínua à previdência

Há carregadores que têm dois empregos, pois as jornadas e horários do Entreposto "possibilitam" a conciliação dos dois empregos. É muito difícil o carregador do pescado conseguir conciliar outra atividade depois da jornada nesse setor, mas há alguns casos, de poucos carregadores, que trabalham no setor das flores ou outra atividade. Uma boa parte dos carregadores do pescado acaba levando mercadorias, que às vezes são sobras e às vezes são compradas, para revender nos fins de semana, próximo ao local em que residem e, assim, complementarem as suas rendas. Como aparece no depoimento: "Sempre tem uma viraçãozinha”.

Já no setor da fruta e dos legumes é mais comum encontrarmos carregadores que fazem os "bicos" depois do horário ou na segunda-feira, dia que o movimento é reduzido. Eles trabalham então como pedreiros, encanadores, eletricistas. Esse fato é atribuído à redução de trabalho na Companhia. Recorremos aos estudos de Malaguti (2000) que identifica a atividade informal como a complementação de renda; em seus estudos sobre o trabalho informal encontra trabalhadores exercendo mais de uma atividade, processo que denominou de ocupações híbridas.

O Sr. Leonides, baiano, trabalhava na antiga Central de Abastecimento, na rua Cantareira. Sua atividade principal sempre foi a construção civil, na qual tinha a função de 
encarregado; ali se aposentou, e continuou na atividade de carregador, complementar à sua renda familiar. Ele veio trabalhar ${ }^{171}$ no pavilhão das flores e se orgulha de ser um dos primeiros filiados ao Sindicato, mostrando o número no jaleco e no carrinho.

Os carregadores têm um trabalho autônomo, porém, na relação de trabalho com os os permissionários e feirantes, sentem-se, como assalariados. Incorporam questões que perpassam por um trabalhador assalariado e as garantias que a lei lhe são asseguradas. Em conversas com carregadores, em momento em que os compradores diminuíam ou dispensavam os seus serviços, ouvimos, eles se declararem como desempregados.Eles trabalhavam para feirantes ou mercados que não vão mais ao CEAGESP por terem fechado ou alterado a sua forma de adquirir os produtos hortifrutigranjeiros ou, simplesmente, por terem reduzido a quantidade de suas compras. Há uma relação de trabalho de muitos anos entre esses carregadores e os feirantes, usuários e mesmo os atacadistas. Estes têm contratos antigos. O rendimento do carregador é diário e não há nenhum tipo de benefício, como autônomo, quando esse é dispensado pelos permissionários ou usuários. Entretanto, uma parte dos carregadores recorre à lei em busca de algum direito, movendo ações trabalhistas contra o permissionário ou outro contratante. Existem lacunas na legislação trabalhistas e a situação acaba configurando-se de forma dúbia. A documentação para mover esses processos, normalmente, é requerida na administração da CEAGESP, que possui o cadastro desses carregadores; são requeridos em média, de 15 a 30 pedidos de declaração por mês, para essa finalidade. ${ }^{172} \mathrm{Nem}$ todos os carregadores concordam que devam requerer esses benefícios, pois não acham ético esse procedimento.

Os depoimentos revelam satisfação com a "autonomia" de não ter horários e regras definidas como existe para um trabalhador assalariado, vejamos alguns registros:

[...] aqui é mais tranqüilo menos enchimento de saco, não tem exigências de mandar e ser mandado, tem que obedecer algumas coisas, nem tanto quanto [...] aqui. (Samuel)

Jessé, piauiense de Inhuma, comenta sobre a vantagem de ser trabalhador autônomo. Além de apontar maiores rendimentos, destaca a possibilidade de ter a "liberdade", de quando quiser ir visitar os pais e parentes na área de origem, sendo que os assalariados não podem sair quando querem. No entanto, alguns depoimentos revelam o lamento de não conseguirem

\footnotetext{
${ }^{171}$ Essa entrevista foi realizada em 2003, e ele se aposentou em 2005, enquanto carregador.

${ }^{172}$ Nos depoimentos essa situação se confirma, um caso conhecido foi dos carregadores que trabalharam para o Pão de Açucar e ganharam a causa. Receberem os valores que variam entre 30 mil reais e 25 mil reais.
} 
outra possibilidade de trabalho, pela idade e pelo nível de instrução que os caracteriza, vejamos:

Consegui e fiquei aqui, tô até hoje e agora não sei aonde vou mais não, porque a idade que eu tô aqui, ninguém quer mais também. Estudo não tenho, profissão não tem, também [...] Devido à minha idade ninguém pega mais não. É melhor, do que ficar pulando de galho em galho. (Heleno, 52 anos).

Essa resposta veio do paraibano, que atualmente é carregador no pescado e, no passado, foi metalúrgico. Nesse depoimento podemos ver a mobilidade do trabalhador do setor da produção, expulso por uma intensa redução nessa mão de obra, para esse setor da circulação, que, na década de 80, ainda absorvia trabalhadores.

Há os carregadores que ponderam e lamentam por não ter os benefícios que a carteira assinada pode trazer, mesmo assim preferem o trabalho por conta própria. Vejamos o depoimento a seguir:

A gente, como autônomo, tem uma liberdade. Agora, com carteira assinada... quem vai assinar a carteira pra gente? Esse rapaz mesmo, hoje se eu falar pra ele: "preciso assinar a minha carteira". Ele assina a minha carteira, tenho certeza. Mas não é vantagem, tem vínculo preso. A gente se limita a ele. Aí acabou o serviço, não pode fazer mais nada. E aí a gente faz um biquinho... não é maior, mas ajuda, ajuda sim [...]. (João)

Esse carregador trabalha com um comerciante de Santos e recebe um valor fixo por semana para carregar a ordem de 100 caixas de pescado; depois ele complementa com outras viagens para outros clientes. Assim, o trabalho autônomo possibilita um faturamento maior.

A inserção do migrante no trabalho autônomo aparece em diversos estudos ${ }^{173}$ tanto aqueles que querem abordar a temática do trabalhador por conta própria como os que estudaram um determinado fluxo migratório. Entre os estudos que focam o trabalho autônomo destaca-se a pesquisa de Reginaldo Prandi (1978), que analisa a diversidade de trabalhadores que essa categoria abrange, na perspectiva da falta de vínculo empregatício. Eles também compõem a paisagem urbana e são trabalhadores caracterizados, no âmbito da divisão social do trabalho, por depender principalmente de sua força de trabalho e, às vezes, de seus familiares.

O trabalho autônomo envolve uma diversidade de tarefas e serviços, como artesãos, profissionais liberais, pequenos comerciantes. Enfim, por essa gama de atividades tivemos que aproximar a nossa lente de aumento para focar nos estudos sobre o migrante carregador

\footnotetext{
173 PRANDI (1978), LIMA (1987), CACCIAMALI (1983), MENEZES (1990), MARTINS (1979) e JAKOBSEN (2000).
} 
do Terminal de Abastecimento. Além de classificar o carregador como autônomo, também se pode qualificá-lo como trabalhador do circuito inferior. Em uma concepção dual, eles estariam classificados como trabalhadores do setor formal e informal, com uma grande divisão entre os regulamentados e os não regulamentados, sem considerar a sua relação de interdependência ou a origem comum desses setores no processo de reprodução e ampliação do capital. Nos estudos da década de 70, encontramos ainda o conceito de trabalho marginal, já superado por boa parte da academia, que percebe que essa atividade não está à margem, mas inclusa no setor produtivo e de circulação da mercadoria ${ }^{174}$. Outros autores ainda trabalham com a divisão clássica de Colim Clark de 1957, e classificam o trabalho autônomo compondo o setor terciário ${ }^{175}$. A crítica a esse agrupamento se faz principalmente sobre o congelamento que sofrem as atividades que podem compor tanto um setor como outro e que, por conseguinte, fogem ao conceito clássico de setor terciário, que inclui as atividades ligadas ao comércio e aos serviços.

Encontra-se também em muitos estudos a concepção de que o trabalho autônomo é classificado como, tipicamente não capitalista, pois a base de compreensão da reprodução do lucro está acentuada na produção de mais-valia, assim, o assalariamento expressaria muito mais o capitalismo do que outras formas de trabalho, como a familiar ou o trabalho autônomo. Entendemos que essa preocupação em definir em o que é típico ou não, nas relações de trabalho sob o capital, não ajuda na compreensão de toda a heterogeneidade de formas de trabalho que a nova fase da reprodução do capital imprime no reordenamento do processo civilizatório.

Todas essa formas de trabalho estão sob a júdice do processo de reprodução do capital, que, atualmente, não só no setor reprodutivo como sobretudo na circulação da mercadoria. Daí a nossa preocupação em estudar uma dessas formas, como a do carregador do Terminal de Abastecimento de uma metrópole.

Para a Organização Internacional do Trabalho o conta própria é definido como a "pessoa que explora seu próprio negócio ou ofício e presta seus serviços diretamente ao consumidor ou para determinada(s) empresa(s) ou pessoa(s)." 176

De todo modo, fomos buscar nos estudos que tratam da inserção do migrante nas ocupações da economia urbana - e encontramos - uma diversidade de pesquisas que elegeram

\footnotetext{
${ }^{174}$ KOWARIK, Lúcio. A espoliação urbana (1993).

${ }_{175}^{175}$ Essa problemática foi discutida por LIPIETZ (1986) e SANTOS (2004).

${ }^{176}$ In JAKOBSEN, 2000, p.8.
} 
os camelôs e o comércio ambulante como base empírica para se pensar a questão ${ }^{177}$. Jakobsen (2000) apontou a origem do trabalho informal na América Latina e no Caribe relacionada à forte migração de trabalhadores do campo para a cidade após a Segunda Guerra Mundial, migração que se deve às transformações no campo, somadas à busca de melhores condições de trabalho na cidade que se industrializava. Isso acabava gerando uma insuficiência de oferta de emprego para atender à demanda. Esse excedente de mão de obra é obrigado então a "inventar seu próprio trabalho - principalmente no comércio e no setor de serviços - como meio de sobrevivência”. Marilda Menezes (1990) concebe que a inserção desses migrantes se explica principalmente por um conjunto de estratégias nas quais ele pode se engajar, mais do que pelas características que se encerram nessa relação de trabalho. Já Woortmann (1984) faz a seguinte afirmação: "Essas atividades freqüentemente constituem não estratégias de sobrevivência, mas mecanismos de acumulação e de ascensão social.” (p. 69). Portanto, para a autora, não se deve equacionar "setor informal", ou produção doméstica, na marginalidade, no subemprego ou na pobreza. A mobilidade do trabalho, no caso do carregador do Entreposto, está em um primeiro momento ligada à possibilidade de se obter algum rendimento, que o não encontrava na sua área de origem; no segundo momento, relaciona-se à possibilidade de se adquirirem maiores ganhos do que em outra forma de inserção.

Prandi (1978) em seus estudos faz uma discussão sobre a estratificação social. Para o autor, existe uma divisão entre o trabalhador por conta própria de baixo rendimento, denominada pelo autor de uma massa marginal, e os trabalhadores por conta própria bem sucedidos. Os chamados marginais procuram alcançar "as oportunidades sociais" e níveis razoáveis de consumo. Nessa ótica, o autor acaba fazendo uma análise dual, pois nos dois grupos distintos, existe uma interdependência entre eles, centrada na mesma origem, que a concepção da mobilidade do trabalho de Gaudemar pode esclarecer melhor. $\mathrm{O}$ acumulo do capital gerado pelo trabalho do carregador possibilita uma mudança de tarefa e ascensão social para alguns, quando acabam obtendo seu negócio próprio, como atacadista ou na sua área de origem. Todavia, esse processo de mobilidade, de ascensão, está restrito a um grupo menor que conseguiu reorientar, preservar e ampliar o seu pecúlio.

A temática do mito da autonomia já foi estudada em pesquisa anterior ${ }^{178} \mathrm{e}$ foi, também, analisada por outros autores ${ }^{179}$; constatam-se processos semelhantes entre os

\footnotetext{
177 SOUZA (1984), BARROS (1988), MONTEIRO (1993), RAMIRES (2001).

${ }^{178}$ In: GOMES, Sueli de Castro (2002).

${ }^{179}$ Outros autores mostram o desejo e o sonho do migrante em se tornar um trabalhador por conta própria como MARTINS (1979), que em seu livro O cativeiro da terra cita a vontade e o desejo dos migrantes italianos de possuírem as suas próprias terras e serem autônomos. Outro autor que demonstra esse processo é SILVA (1997),
} 
carregadores do Terminal, dentre os quais a concepção de liberdade vem à tona nas suas próprias respostas. O desejo do indivíduo de romper as regras de horários e ser dono de si, almejando a sua autonomia, somado à possibilidades de rendimentos maiores que o salário fixo, máscara outros processos que correm paralelos à sua condição de trabalhador. Martins (1979) considera a possibilidade de o pecúlio liberar o trabalhador da tutela do patrão, no entanto, esse ideário o leva a produzir mais riquezas e "enriquecer a burguesia". Na ótica de Gaudemar (1977) sobre a mobilidade do trabalho, ele identifica o duplo sentido de liberdade contido no trabalho autônomo, assumido pelo migrante:

Por mais forçada que possa ser a partida, a imigração é também muito largamente interiorizada pelos imigrantes como meio de acumulação individual destinada a assegurar o regresso ao país quer como pequeno investidor, pequeno comerciante, quer como pequeno artesão. A exploração forçada é freqüentemente suportada na medida em que, no fim, há a imagem de uma casa, de uma camioneta, de uma garagem, de uma pequena loja... Daí resulta a ambigüidade de muitas situações.(GAUDEMAR, 1977: 40)

De tal modo, existe uma contradição no migrante trabalhador autônomo, pois ao mesmo tempo que nega o assalariamento, ele se sujeita à mobilidade forçada, revelando as outras faces da mobilidade do trabalho. A ilusão da autonomia obscurece“...os lugares de inserção e de manifestação da mobilidade do trabalho, todos os espaços de sujeição dos corpos produtivos", ocorre, então a sujeição ao capital. Há uma dupla dimensão da liberdade sob o capital: a sua positividade considera a livre circulação do trabalhador enquanto sua negatividade o obriga a circular porque é desprovido dos meios de produção. ${ }^{180}$ Os desejos de autonomia e de ter o seu próprio negócio aparecem entrelaçados com a vontade de fazer parte, de estar incluído ${ }^{181}$.

com o estudo dos bolivianos em São Paulo. Dessa maneira pensamos também o trabalhador autônomo que procura fugir das regras da empresa que controla seu tempo e seus movimentos. Entretanto, contraditoriamente, esses estão expostos às longas jornadas de trabalho, discutida também em outras pesquisas, e às dificuldades do cotidiano do comerciante, já discutidas anteriormente. EVELYN (1988) identifica nos trabalhadores temporários essa ilusão do trabalho por conta própria, que na verdade é uma negação ou resistência ao assalariamento.

${ }^{180}$ VAINER (1996), GAUDEMAR (1977).

${ }^{181}$ MARTINS (1988a). 


\subsection{Considerações sobre o trabalho na modernidade}

Em Marx, encontra-se uma duplicidade de concepções sobre o trabalho, primeiramente, como uma atividade social que faz a mediação entre a natureza e o homem, produzindo produtos específicos com o propósito de satisfazer as necessidades humanas e em outro momento, desenvolve seus estudos sobre o trabalho sob o manto do capitalismo; é nessa trilha que segue a nossa preocupação, na relação do trabalho e o capital, em sua determinação histórica.

Encontramos autores como Postone (2000), Kurz (1996), Krisis (1999) que reconsideram a teoria do trabalho ontologizado e supra-histórico e seguem a análise de sua forma, em que focam a exploração econômica abstrata da força de trabalho humana, compondo como elemento da modernização e se aproximam do Marx que aponta o trabalho como uma forma do capital produzir valor, portanto, assinala a crítica ao trabalho, pois esse detém um papel crucial nas características básicas da modernização. Assim, "O 'trabalho' é, e, sua essência, a atividade não livre, não humana, não social, determinada pela propriedade privada. A superação da propriedade privada se efetivará somente quando ela for concebida como superação do 'trabalho'.” (MARX apud KRISIS, 1999:80)

Vejamos como Robert Kurz (1996:25) argumenta e debate contra a forma do trabalho naturalizada e supra-histórica:

Essa forma específica do trabalho e o conceito de trabalho correspondente são de fato incompatíveis com todas as formações sociais anteriores da história humana, porque nestas o trabalho, seu produto e a apropriação deste ainda aparecem essencialmente em sua forma concreta, direta e sensível: como 'valores de uso', na linguagem da economia política. Ainda que o trabalho, como labor no sentido antigo, como estafa e moléstia, ocupasse completamente o horizonte da vida da maioria das pessoas, isso acontecia devido ao grau de desenvolvimento relativamente baixo das forças produtivas, no 'metabolismo entre os homens e a natureza'(Marx); o trabalho era, portanto uma necessidade imposta pela natureza, porém precisamente por isso nenhum dispêndio abstrato da força de trabalho e nenhuma atividade social que traz em si a sua própria finalidade.

Assim, o autor segue diferenciando o trabalho sob o capital, mais precisamente no Sistema Produtor de Mercadoria, em que as forças produtivas, frente a industrialização e a tecnologia, rompem essa relação de "primeira natureza", e a coerção da sociedade sobre o trabalho passa a ser secundária, denominada de "segunda natureza", na leitura do processo de 
Marx. De todo modo, nos interessa entender o comportamento do trabalho abstrato (nas palavras de Marx) sobre as transformações impostas pela modernização.

Gaudemar (1977), em sua obra, intitulada A mobilidade do trabalho e a acumulação do capital, realizou um estudo sobre os diferentes enfoques no trato sobre a mobilidade do trabalho. Ele versa, inicialmente, sobre a ótica clássica e neoclássica, cujo maior representante é Ricardo e faz, também, considerações sobre Adam Smith e os modelos de Walras. Essas teorias enfatizam o deslocamento espacial dos homens como uma forma de equilíbrio econômico, correspondendo ao progresso e desenvolvimento da economia ou mesmo, como uma forma perfeita de atender às necessidades do mercado. Posteriormente, o autor discute a ótica marxista de mobilidade do trabalho, à qual ele se filia teoricamente. Assim, refutando qualquer tese de equilíbrio, procuramos ter como ponto de partida os estudos de Gaudemar, nos aproximando da conceituação de mobilidade do trabalho e também do próprio significado do trabalho conforme a acepção marxista.

O conceito de mobilidade do trabalho corresponde às formas de existência da força de trabalho como mercadoria, aparece e estabelece a medida da análise destas formas, nos seus múltiplos modos de submeter-se ao capital. Portanto, a necessidade de caracterizar essa mercadoria específica que é a força de trabalho, nos leva a clarear os processos ocultos da ampliação do capital. ${ }^{182} \mathrm{O}$ conceito possibilita o entendimento das diversas formas que o trabalho toma na produção e na circulação quando se utiliza da força de trabalho. ${ }^{183}$

Essas formas de existência da força de trabalho, vistas como amontoado de mercadorias, abarcam uma multiplicidade de relações sociais, entre elas as redes de relações que são pontes para a inserção em algum mercado de trabalho, como identificamos em nossa pesquisa no Entreposto de Abastecimento da Metrópole da Grande São Paulo. Em um local de valorização do capital, em que a circulação das mercadorias é explicitada na paisagem, ganha visibilidade, podemos encontrar uma das formas da força de trabalho na figura do carregador. Assim, analisa o autor sobre a mobilidade:

Por intermédio de sua mobilidade, a força de trabalho está portanto presente no mercado de trabalho, de onde quer que provenha, tanto de esferas não capitalistas como nas esferas capitalistas e como tal compradas. (GAUDEMAR, 1977:342-343)

A tese de Marx sobre a força de trabalho como mercadoria é que por definição móvel, ou melhor dizendo, ela é capaz de se tornar mercadoria necessária à valorização do capital. ${ }^{184}$

\footnotetext{
${ }^{182}$ Gaudemar, A Mobilidade do trabalho e a acumulação do capital, p.341-342.

183 Id. p.344.

${ }^{184}$ Id. p.390.
} 
O trabalho adquire um valor de uso para o capital ${ }^{185}$ e pode produzir um novo valor para o mercado. As formas "primitivas" da gênese da força de trabalho no mundo das mercadorias estão na mobilidade espacial, mas as formas "acabadas" da força de trabalho podem abranger uma diversidade de mobilidades que não se restringe somente ao deslocamento espacial, mas também, ao setorial, social, e outras tantas formas que possam sofrer mutações. ${ }^{186}$ Esses processos nos conduziram as diferentes trajetórias de trabalho que os migrantes por nós estudados realizaram, e realizam, para vender a sua força de trabalho.

A definição de força de trabalho para Marx: “...o conjunto de faculdades físicas e mentais, existentes no corpo e na personalidade viva de um ser humano, as quais ele põe em ação toda a vez que produz valores de uso de qualquer espécie." 187 fornece instrumento para entender como essa mercadoria que possui um valor de uso, ganha um valor de troca, podendo ser trocada por dinheiro e se realizar no seu circuito; então existe para Gaudemar um processo de produção de força de trabalho. $\mathrm{O}$ valor da mercadoria-trabalho será determinado pelo tempo despendido à sua produção. Para a venda dessa mercadoria, o trabalhador deverá ser livre. Aqui, a idéia de liberdade ganha duplo sentido, pois ao mesmo tempo em que o trabalhador tem a liberdade de vender o seu esforço físico, como qualquer outro bem, ele não tem opção de não o fazer, sendo obrigado a vender sua força de trabalho para a sua reprodução. Vejamos mais:“Mas esta 'liberdade' da força de trabalho transforma-se no seu contrário desde a sua entrada no mercado de trabalho. E aí o local da limitação, das relações de forças." 188

Nessa condição dupla da liberdade, o trabalhador deve ser móvel, apto para qualquer deslocamento e modificações, atendendo às flexibilidades do capital; advém daí o conceito de mobilidade do trabalho. Neste se reforça a docilidade, ou melhor, a submissão dos corpos humanos a todo o tipo de esforço e exigência para a ampliação do capital.

Gaudemar identifica as diferentes formas que estão contidas na mobilidade do trabalho, sujeitas ao capital, como a elasticidade da oferta de trabalho, em que faz alusão aos supranumerários, uma sobrepopulação relativa, ou até mesmo ao chamado exército de reserva, entre outros exemplos de sujeição. Nesse caso, devemos fazer uma reserva a esse debate desenvolvido na década de 70, quando era possível, se fazer uma referência a um excedente de trabalhadores que seriam absorvidos em momentos de crescimento da economia. No entanto, o que assistimos nesse período pós-fordista é a exclusão desse excedente do

\footnotetext{
185 Id.p. 403.

186 Id. p. 399.

187 MARX, (1996:187).

${ }^{188}$ Gaudemar, p.396.
} 
trabalho regulamentado, levando esses homens, que antes compunham o exército de reserva a se tornarem sobrantes ${ }^{189}$.

Em Marx encontramos a tese de que o trabalho é fonte de toda riqueza social, no entanto, o que assistimos é a redução do trabalho. Nesse quadro Postone (2000) aponta na leitura dos Grundisse o seguinte:

Uma nova formação social pode ser criada na qual o "trabalho excedente da massa tenha cessado de ser a condição para o desenvolvimento da riqueza geral, da mesma forma que o não-trabalho de poucos, tenha deixado de ser a condição para o desenvolvimento das potencialidades gerais do cérebro humano." (MARX apud POSTONE, 2000: 125)

Gaudemar exemplifica uma outra forma de sujeição ao capital, que é "a plasticidade da força de trabalho face às transformações dos processos técnicos e adaptabilidade dos homens aos novos ofícios que aqueles geram.” (p.343). Sendo assim, a elasticidade deu lugar à plasticidade, ou melhor, a um esgarçamento, em que o excedente de força de trabalho mobiliza-se para o trabalho precarizado, sob a máscara do mito do trabalhador autônomo.

Em Marx, encontramos a categoria do carregador classificada como lumpenproletariado, vejamos:

A pretexto de fundar uma sociedade beneficente, o lumpen-proletariado de Paris foi organizado em facções secretas, dirigidas por agentes bonapartistas e sob a chefia geral de um general bonapartista. Lado a lado com roués decadentes, de fortuna e de origem duvidosas, lado a lado com rebentos degenerados e aventureiros da burguesia, havia vagabundos, soldados desligados do exército, presidiários libertos, forçados foragidos das galés, chantagistas, saltimbancos, lazzarani, punguistas, trapaceiros, jogadores, maquereaus [alcoviteiros], donos de bordéis, carregadores, literatos, tocadores de realejo, trapeiros, amoladores de facas, soldadores, mendigos, em suma, toda essa massa indefinida e desagregada e flutuante, a que os franceses chamam la bohème;... (MARX, 1987 [1852]: 83).

Essa classificação em que Marx reuniu os trabalhadores considerados "refugo" ou "escória da sociedade", denominados por alguns "excluídos", ou melhor, "inclusos precariamente", tem que ser retomada e pensada nas diferentes formas que o trabalho tomou na modernização. Analisando as características do carregador da CEAGESP, ainda mais aquele regulamentado pelo Estado ficaria difícil classificá-lo de forma imediata como um lumpen. Pois, aos poucos esses ofícios clandestinos foram ganhando espaços de legitimidade diante do Estado e sendo regulamentados, pagando taxas, seguindo normas, formatos que são aceitos pela sociedade, como necessários para a sua manutenção, em que a mobilidade do trabalho, permite uma ascensão dessa categoria, um pequeno pecúlio. Krisis (1999) comenta

\footnotetext{
${ }^{189}$ KRISIS (1999).
} 
sobre as formas de trabalho em que o prestador de serviços sonha em ser dono dos meios de produção, ou seja, são as pseudo-possibilidades que existem. Estes homens são os inclusos de segunda categoria sonham ser os consumidores de primeira categoria, em um movimento que segue no sentido de reforçar essa estrutura e rompê-la. Assim, a lógica da inclusão no processo de modernização, transforma o "subemprego" em exemplo de iniciativa privada, em exemplo de empreendedorismo, um discurso voltado para esse enorme exército de desempregados, os sobrantes. A modernização traz um desemprego estrutural de dimensões gigantescas, empurrando essa força de trabalho para a condição de autônomo, trabalhar por conta própria. Essa possibilidade dos indivíduos serem empresários de sua força de trabalho e de sua própria previdência social ${ }^{190}$ se torna uma "solução precária" para o Estado, que busca um planejamento da economia que está sob o controle da mercadoria.

\subsection{O Sindicato e a delimitação de território}

Os carregadores estão organizados em um sindicato denominado de SINDCAR, Sindicato dos Carregadores Autônomos de Hortifrutigranjeiros, Pescados e das Centrais de Abastecimento do Estado de São Paulo, que tem a sede localizada no Entreposto, em um grande galpão. No entanto, nem todos são sindicalizados, pois dos 3405, apenas 2880 são filiados ${ }^{191}$.

A história do movimento desses trabalhadores, segundo um ex-militante do partido comunista, registra uma greve que ocorreu em 1978, baseada na experiência dos estivadores do Porto de Santos. Era o período da Ditadura Militar; a greve mobilizou apenas uma parte do Entreposto, os legumes e o MLP, reivindicando melhores condições de trabalho. No entanto, o movimento foi reprimido pela polícia. O gerente do Entreposto, na época, mandava bater nos carregadores.

...ele desceu lá e mandou a polícia baixar o reio nos carregadores, o cacete. [...] O tenente chegou e disse: Quem tá parado aí? Espingarda (carregador) disse: 'Eu tô.'Passou a mão na orelha, derrubou, pisou o pé no pescoço,

\footnotetext{
${ }^{190}$ KURZ (1999)

${ }^{191}$ Em novembro de 1999, fora publicado no Jornal Elo, o registro de quase 4 mil associados. Esse número envolve não só os filiados da Capital, mas também de todos os CEASAS do Interior de São Paulo. Portanto, já que não foi disponibilizado somente o número dos filiados da Capital, deduzimos que esse número é bem inferior ao total de 2880. Concluímos que em razão da crise instalada no Terminal, conseqüentemente, esse fato repercutiu no número de filiações no Sindicato, processo semelhante em outros sindicatos e associações.
} 
meteu o cacete. Então, naquela época aí, os carregadores denunciaram. E ele tomando os crachás tudinho na mão do $F$... [...] mandou a polícia descer o cacete, meteu o cacete. Os carregadores denunciavam... mandou a polícia descer o cacete... um tempo (ele) tomou a tabela e rasgou... Era uma cara sem respeito. (Zé Pinheiro)

Foram vários passos e conquistas ao longo dos anos até os carregadores constituírem o seu Sindicato com sede e conseguirem o galpão para guardar seus carrinhos. Eles iniciaram a sua organização com uma cooperativa depois, veio uma associação e depois ainda outra associação, denominada UNICAR (União dos Carregadores), até ser fundado, em 1990, o Sindicato dos Carregadores, SINDCAR. Até então, os carregadores eram filiados ao Sindicato dos Funcionários da Companhia (SINDBASF), o que gerava muitos conflitos, pois os interesses se diferenciavam.

$\mathrm{Na}$ década de 90, ocorreram duas grandes greves paralisando todo o Terminal. A primeira grande paralisação reivindicava um aumento na tabela de preços cobrados pelos carregadores. No início do movimento, pedia-se um aumento de $18 \%$, após o movimento de paralisação conquistou-se um aumento de $40 \%$ acima da tabela. Nesses movimentos as paralisações começaram à meia-noite e foram até às 11:00, do mesmo dia.O segundo grande movimento foi uma manifestação de denúncia da corrupção da diretoria, cujo presidente era Fuad Nassif Valilla, ${ }^{192}$ e o diretor operacional, Miguel Apolônio. O movimento, também começou à meia noite e foi até ás 11:00 do mesmo dia, o carro de som ficou em frente à gerência. O fato chegou até Brasília, sendo ministro, na época, Roberto Torres; movimento culminou na queda da diretoria. Veja as imagens do movimento (Ver fotos $n^{\circ} 28$ e $n^{\circ} 29$ ).

192 Gestão ocorreu entre 31/07/1966 e 24/05/2001, no governo de Fernando Henrique Cardoso 


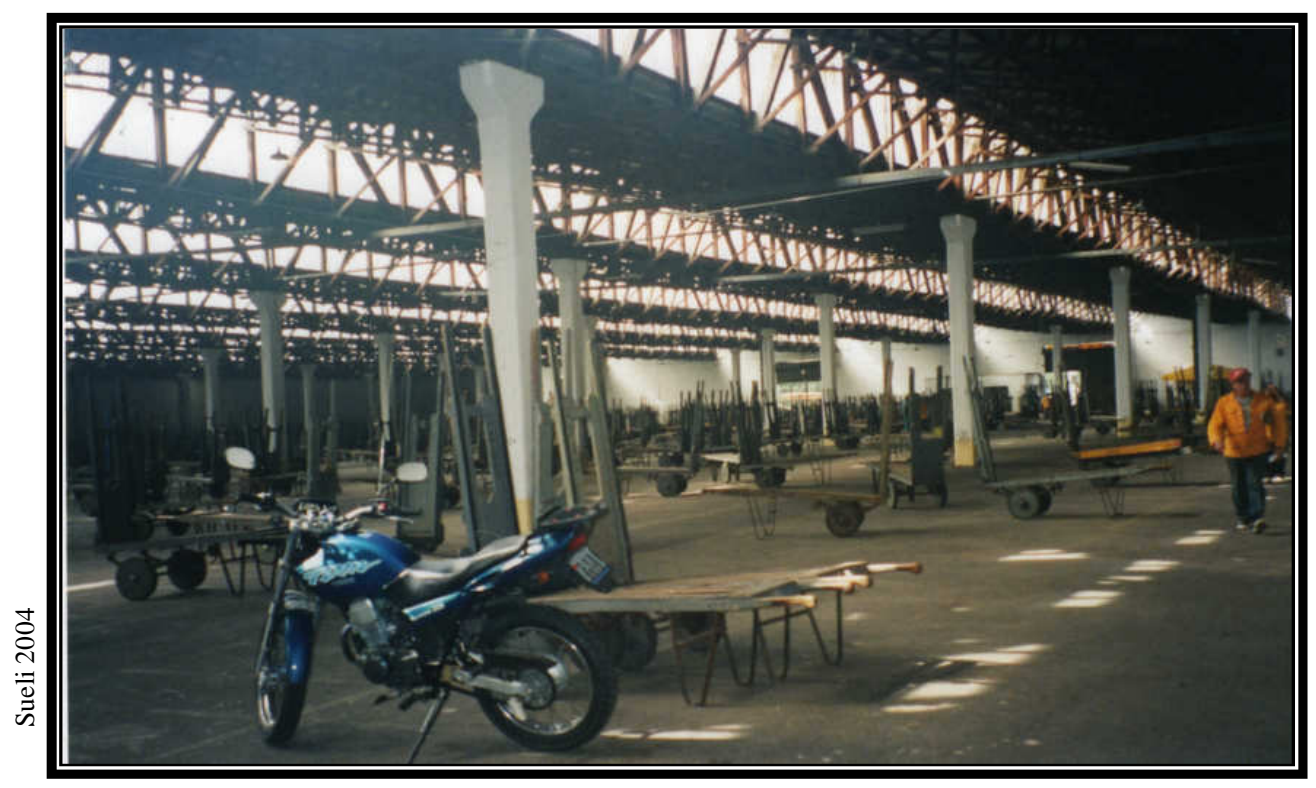

Foto 25: Galpão dos Carregadores - SINDCAR

Foto 26: Sede do Sindicato (SINDCAR) no Galpão dos Carregadores.
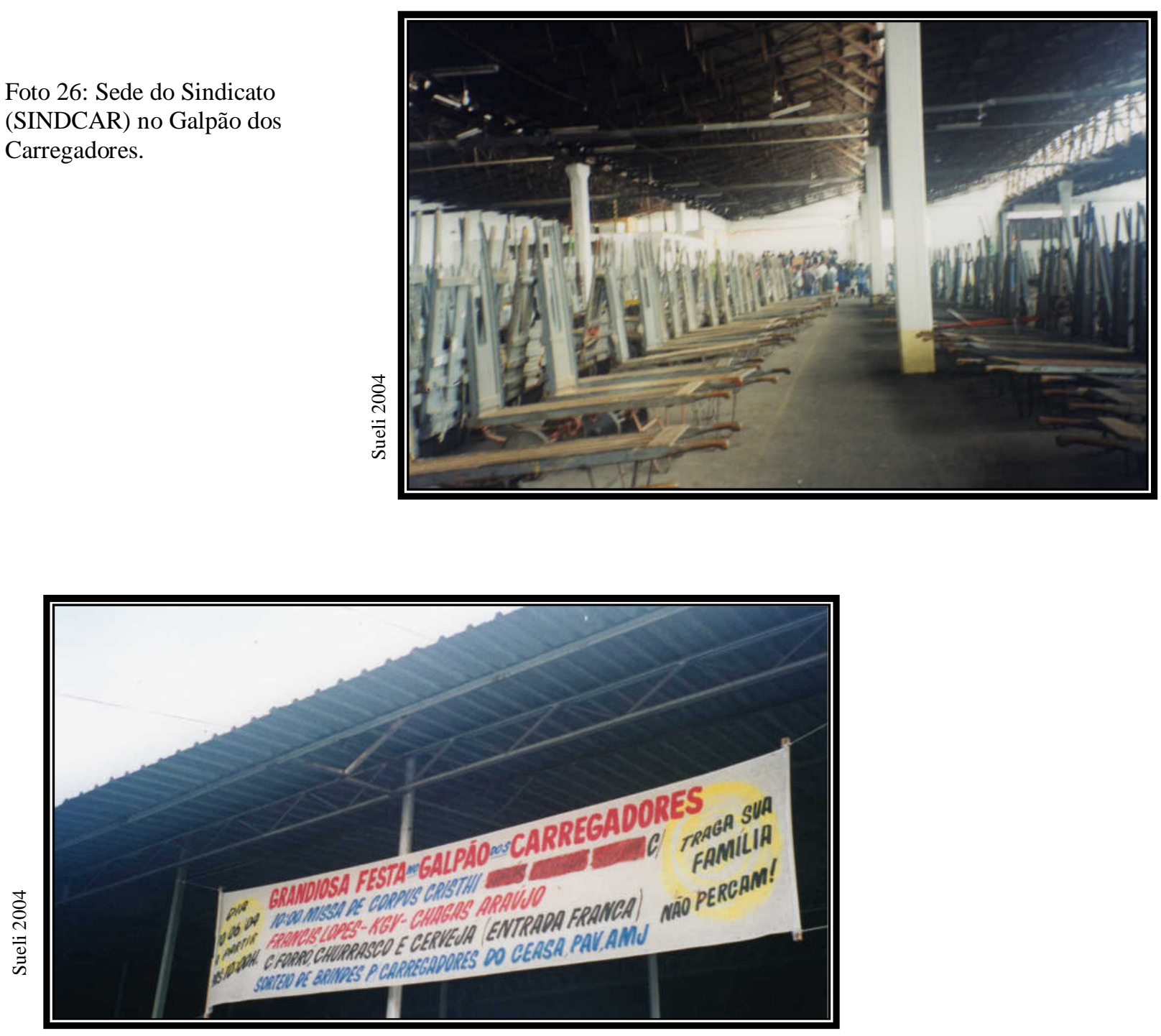

Foto 27: Faixa divulgando evento promovido pelo sindicato. 


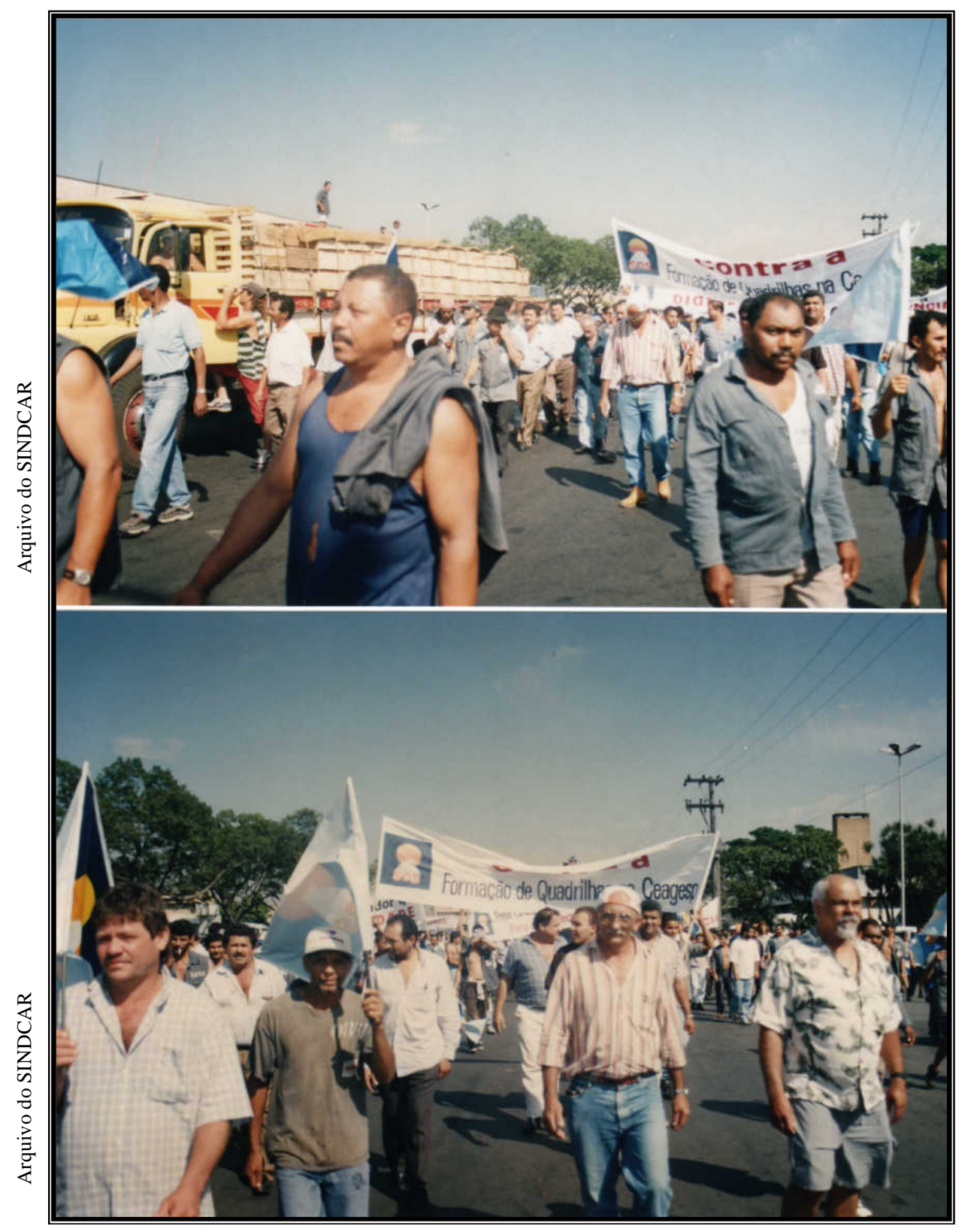

Foto 28 e 29: Movimento dos Carregados, na década de 1990, combatendo a corrupção da administração da CEAGESP. 


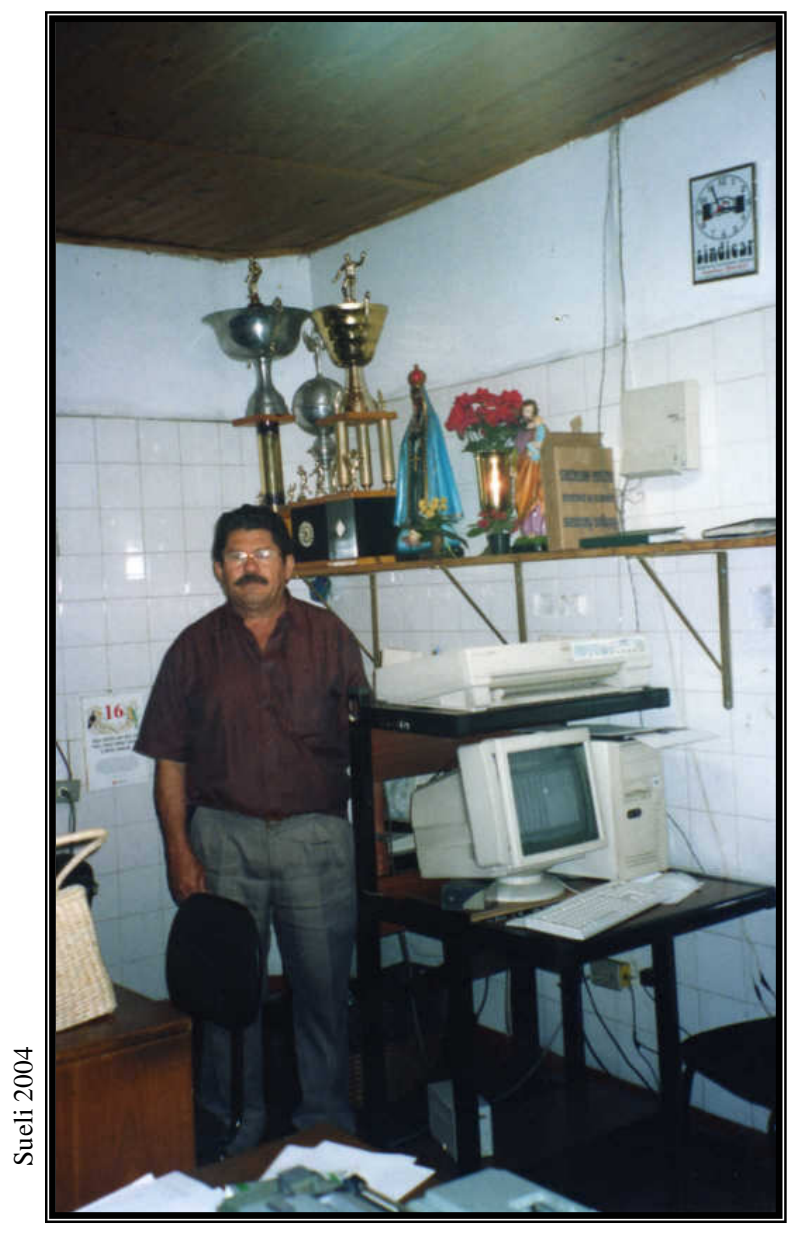

Foto 30: Zé Pinheiro, presidente do sindicato.

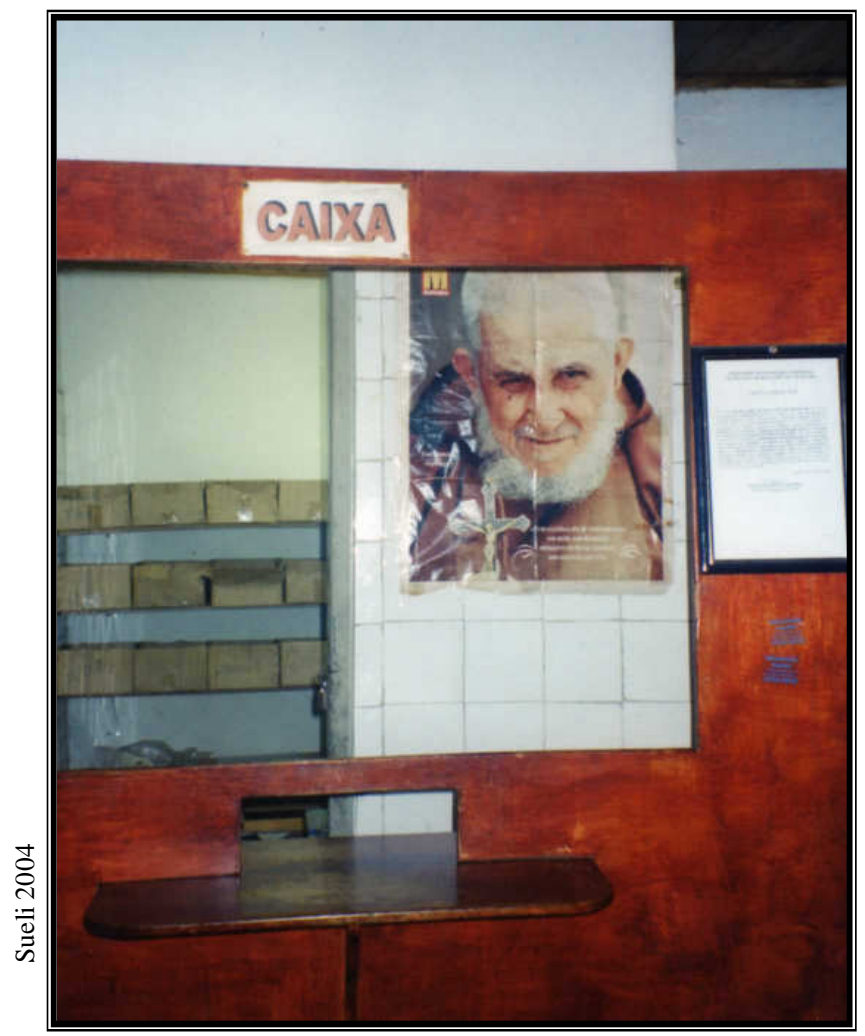

Foto 31: Frei Damião na parede do SINDCAR 
O Sindicato participou também de campanhas de donativos organizadas pela frente sindical a que são filiados e pela Igreja Católica. A diretoria, junto com o Pe. Donizete, do Parque Continental, ${ }^{193}$ levou alimentos para a Paraíba, na região de fome.

Tanto o Sindicato dos Funcionários quanto o Sindicato dos Carregadores são filiados a uma Frente Sindical, SDS (Social Democracia Sindical), que no passado era vinculada à Força Sindical. Essa frente é oriunda de uma divisão da Força Sindical, presidida pelo Alemão, também presidente, do Sindicato dos Funcionários da CEAGESP, o mesmo que auxiliou na fundação do SINDCAR. ${ }^{194}$ As eleições do Sindicato dos Carregadores ocorrem de quatro em quatro anos. ${ }^{195}$. A última teve chapa única, sendo que a oposição não quis compor uma chapa. O piauiense de Pio IX, Zé Pinheiro, presidente do Sindicato, ajudou a fundá-lo, e desde o início assumiu a liderança e a representação dos carregadores. Ele tem um filho trabalhando como carregador e outro como funcionário do Sindicato. ${ }^{196}$

Até o fim dos anos 80, os carrinhos eram guardados nas ruas internas do Entreposto e nos boxes, isso gerava uma série de problemas; os roubos dos carrinhos eram comuns. $\mathrm{O}$ Sindicato conquistou o espaço de um grande galpão, que já existia desde o início do Terminal, ao lado do mercado do peixe, no início dos anos 90; este local além de sede, é utilizado também para guardar os carrinhos. Os carregadores mais antigos contam, que hoje está mais organizado, pois cada carrinho tem um número, o mesmo do uniforme e, na entrada do Sindicato, é feito um controle; em caso de qualquer desconfiança, pede-se a carteirinha. Não existe um espaço determinado para cada carrinho, apenas uma pintura no chão para definir as vagas. Paga-se uma taxa de $\mathrm{R} \$ 12,00$ mensais para guardar o carrinho, o que é válido para filiado e não filiados. Os primeiros contribuem com uma taxa mensal de $\mathrm{R} \$ 6,00$, o que os possibilita pagar menos nos exames médicos e outros serviços de saúde.

Além do espaço para guardar o carrinho, eles recebem um atendimento dentário e médico ${ }^{197}$. Há uma área reservada com chuveiros e banheiros ${ }^{198}$, onde após a estafante jornada, o carregador pode tomar um banho antes de ir embora. O Sindicato criou o Fundo de Amparo ao Carregador (FAC). O carregador contribui com $\mathrm{R} \$ 1,00$ por mês e, em caso de doença e que precise de afastamento, ele receberá cesta básica mensalmente, os

\footnotetext{
193 Loteamento localizado no distrito do Jaguaré, próximo do Terminal.

${ }^{194}$ Essa corrente sindical tinha uma aproximação com o Partido Social Democrático Brasileiro.

195 As últimas eleições ocorreram 14 de fevereiro de 2007.

${ }^{196}$ Um dos seus filhos cursa a faculdade de Direito na FIEO e é diretor do Sindicato.

197 Implantado a partir de 2001.

198 No banheiro existem armários de madeira usados para guardar seus pertences. Ainda, são precárias as suas instalações, pois faltam pias e não há portas nos sanitários.
} 
medicamentos, e outro auxílio, quando necessário. São em média 40 cestas básicas por mês, considerado um número baixo de afastamentos.

Nesse galpão, além do espaço reservado para mais de 3000 carrinhos, há uma oficina de manutenção, banheiros, consultórios e a sede - escritório do Sindicato. Nesta sala pudemos ver nas paredes muitas fotos, imagens do presidente do Sindicato com políticos e personalidades, e também do time de futebol dos carregadores, que não existe mais. Os troféus ficam expostos ao lado da imagem de Santa Luzia. Zé Pinheiro, que organizava a equipe para jogar com outras equipes de futebol, atribui a sua falta de tempo para dar a continuidade à prática do futebol entre os carregadores. No ano de 2003, o Sindicato organizou uma festa no mês de junho (10.06.2003), além da missa, houve um forró com alguns artistas ligados à comunidade nordestina. O Sindicato promove as missas em datas significativas, uma no período do Corpus Christi (junho), a missa de Santa Luzia (Dia 13 de dezembro) e a missa de Nossa Senhora Aparecida. Essa tradição foi trazida pelo devoto de Santa Luzia ${ }^{199}$, Zé Pinheiro, piauiense, presidente do sindicato. Vejamos as imagens a seguir (fotos $n^{\circ} 32$ e $\left.n^{\circ} 33\right)$.

Estivemos presentes em parte dos eventos promovidos pelo Sindicato. Segue a relação de eventos promovidos e registrados, nos últimos anos:

- Festa de São João em 23 de junho de 2000, no galpão dos carregadores, animada forrozeiro José Manuel, locutor da Radioaudio Entreposto. A imprensa local registrou a presença, aproximadamente, de três mil pessoas. ${ }^{200}$.

- Missa de Corpus Christi, em junho de 2004; compareceram mais de três mil pessoas nessa missa, rezada pelo Pe. João Carlos Borges. Estiveram presentes o Deputado Estadual pelo Partido dos Trabalhadores Emídio de Souza, atual Prefeito pelo município de Osasco, e o Presidente da CEAGESP, Walmir Prascidelli (da antiga gestão). Após a missa, acorreu uma churrascada e o forró foi animado por Francis Lopes. (Ver foto $\mathrm{n}^{\mathbf{0}} 27$ ).

- Missa de Santa Luzia, no dia 13 de dezembro de 2004, rezada pelo Pe. Benedito, bispo da Lapa

- Missa de Corpus Christi, celebrada pelo Pe. Paulo, da arquidiocese de Natal, em 26 de maio de 2005.

\footnotetext{
199 Santa Luzia tem muitos devotos no Estado do Piauí.

${ }^{200}$ Jornal Elo (jornal dos permissionários), em junho de 2000.
} 


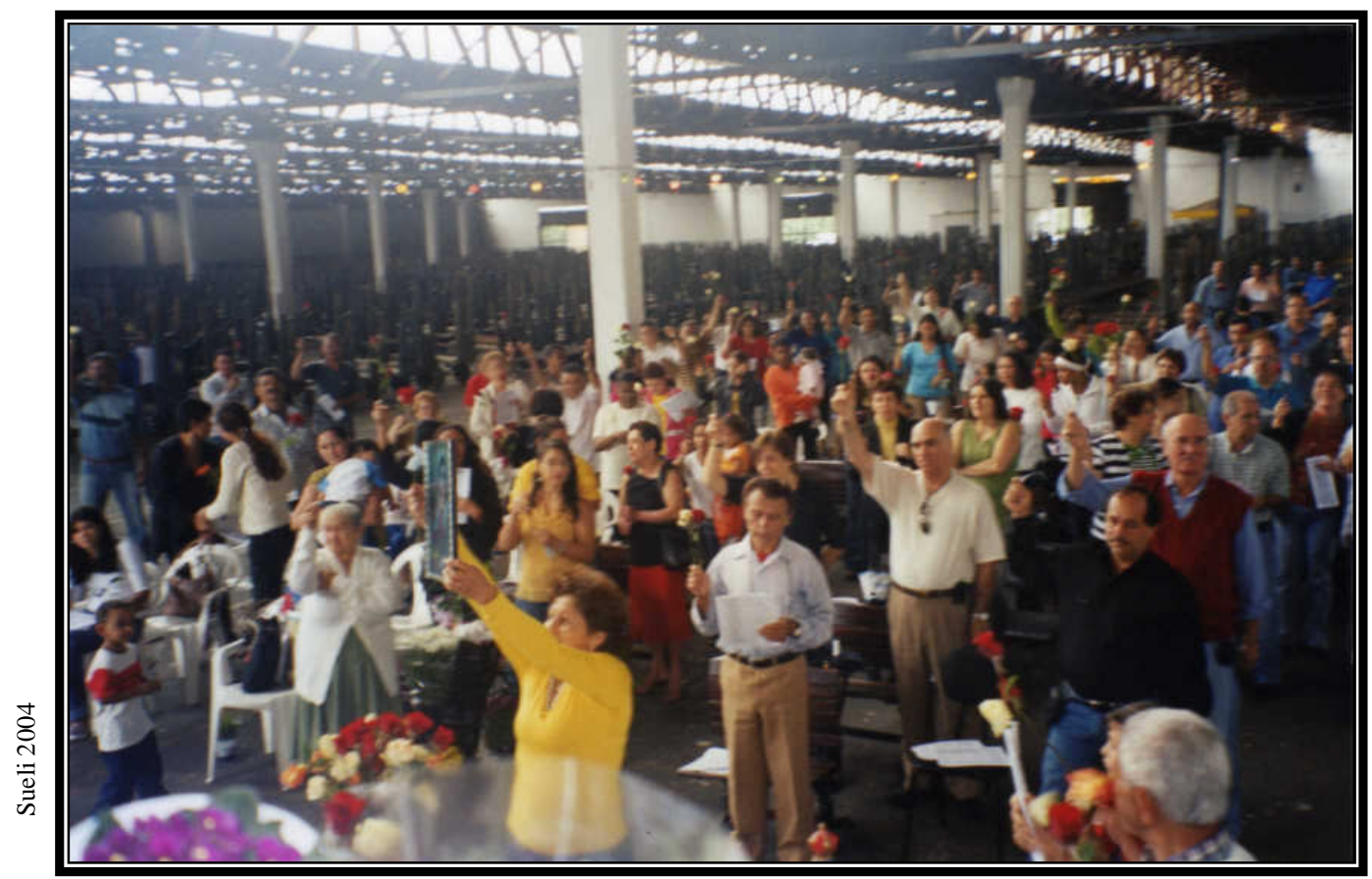

Foto 32: Missa de Santa Luzia no Galpão dos Carregadores.

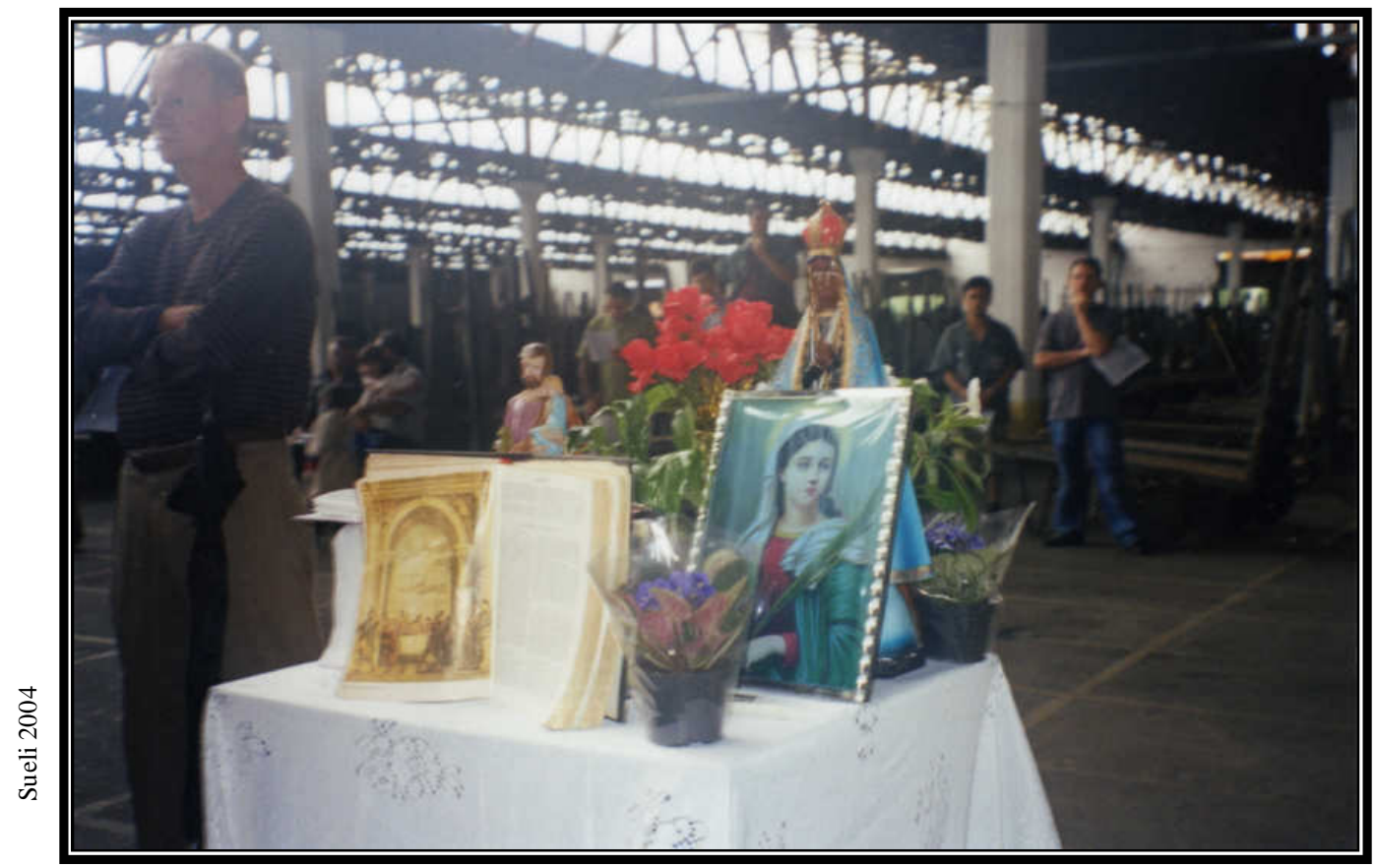

Foto 33: Altar com a imagem de Santa Luzia no quadro, exposta na Missa. Essa Santa é venerada por muitos piauienses. 
Missa de Nossa Senhora Aparecida, celebrada pelo Pe. João Carlos Borges, em 12 de outubro de 2005.

- Missa de Santa Luzia, celebrada pelo bispo Dom Benedito, da região da Lapa, dia 10 de dezembro de 2005.

- Missa de Corpus Christi, celebrada pelo Pe. Cícero, vice-reitor do Seminário Católico da Freguesia do Ó, em junho de 2006.

- Missa de Nossa Senhora da Aparecida celebrada pelo Pe. João da Paróquia do Rio Pequeno, dia 12 de outubro de 2006.

- Missa de Ação de Graças de Santa Luzia, celebrada pelo bispo Mamed, da Cúria Metropolitana da Lapa, dia 09 de dezembro de 2006. Estavam presentes como sempre, vereadores (Aluísio Pinheiro) e deputados estaduais (Marcos Martins) vinculados a essa comunidade. Nesse evento, ocorreu o batizado da neta do presidente do Sindicato.

As missas são animadas pelo coral Amigos do Pe. Kirano e após seu término sempre é oferecida uma farta mesa de frutas para os participantes, ou até mesmo flores. Os participantes já esperam com sacolas a doação.

Existe um trabalho de evangelização na CEAGESP e na Escola Nossa Turma realizada por um diácono permanente.

$\mathrm{Na}$ parede do Sindicato, ao lado da tesouraria, encontramos forte símbolo da cultura nordestina presente, a imagem do Frei Damião (ver foto $\mathrm{n}^{\mathrm{o}} 31$ ).

Assim, a presença da cultura nordestina é um indicador desse território no Terminal da Vila Leopoldina, em que estes encontram uma forma de inserção na ocupação de carregadores. No galpão dos carregadores encontra-se a venda diária de produtos alimentícios oriundos do Piauí ${ }^{201}$. Assim, o alimento ajuda a matar a saudade da terra natal desses trabalhadores.

Uma das conquistas do Sindicato, em 2001, foi a construção de um poço artesiano, pois, naquele momento, constatou-se que o maior gasto com água vinha do galpão dos carregadores. Já que estes após a sua jornada, já dissemos, tomam banho no espaço do Sindicato. O valor gasto naquele período era de $\mathrm{R} \$ 25$ mil reais, e o Sindicato, e recebeu a colaboração do deputado Xico Graziano (PSDB), para construção do referido poço ${ }^{202}$, sendo beneficiados, também, os permissionários.

\footnotetext{
${ }^{201}$ No mês de janeiro, os comerciantes viajam para o Piauí para buscar mais mercadorias.

${ }^{202}$ Tem 280 metros de profundidade e capta $100 \mathrm{~m}^{3}$ de água por hora, está localizado no estacionamento do pavilhão MFE - C.
} 
No entanto, a maior luta do Sindicato está no campo da manutenção do trabalho do carregador autônomo diante da redução da quantidade de trabalho. Já houve diversas propostas de diretorias anteriores ${ }^{203}$ para uma redução para mil do número de carregadores . O Sindicato reagiu com uma ameaça de greve e essa proposta foi barrada. Depois, outra direção propôs que se fizesse rodízio dos carregadores, que trabalhariam em dias intercalados; o Sindicato conseguiu barrar essa proposta e coloca como pauta o combate aos clandestinos para garantir o serviço da categoria.

Os artigos publicados pelo sindicato no Jornal Entreposto até o ano de 2005 foram algumas das fontes para entendermos a dinâmica do movimento sindical. ${ }^{204}$ Os textos traziam uma diversidade de assuntos de interesse da categoria, assim como as benfeitorias realizadas pelo presidente do Sindicato, como o auxílio na Escola "Nossa Turma", na Páscoa, Natal, Dia das Crianças e registros do apoio a candidatos do município de Osasco ${ }^{205}$. Identificamos como mais constantes temas como a saúde do trabalhador ${ }^{206}$, os eventos promovidos pelo Sindicato e as reivindicações.

Em fevereiro de 2004, foi publicada a pauta de reinvidicações ${ }^{207}$, entregue em reunião com a primeira gestão do governo Lula, sendo que o presidente era Walmir Prascidelli:

1- Retirada de carregadores clandestinos em todos os setores da CEAGESP

2- Solução dos problemas de congestionamento de carros em todos os setores sendo um dos principais pontos o Pavilhão MLP

3- Ao redor da Feira de Flores do Pavilhão MLP sempre tem peruas Kombi. A fiscalização está defasada, quando precisa-se de fiscais só é possível encontrá-los após os fatos a serem denunciados já terem ocorrido

4- No pavilhão MFE-A há tantos buracos no asfalto que não tem condições de se trabalhar, também no setor de pescados e vários outros setores da CEAGESP.

5- Após 15 horas o número de clandestinos dobra em todo o mercado.

6- Melhor para a segurança é todos usarem uniformes, carregadores e funcionários de firmas.

\footnotetext{
${ }^{203}$ Nas gestões ligadas ao governo Fernando Henrique Cardoso.

${ }^{204}$ Depois de 2005 não encontramos mais artigos escritos pelo Sindicato, pois o Sindcar perde o espaço no jornal.

${ }^{205}$ Esse fato reforça os laços que essa categoria tem com município conurbado com São Paulo.

${ }^{206} \mathrm{~A}$ preocupação com a saúde do trabalhador, guiada pelo casal de dentistas voluntários e a doutora Célia Medina aparece através das campanhas: mês de agosto de 2005, Campanha da Vacinação que ocorreu no espaço do Sindcar, realizada pelos funcionários da Secretaria da Saúde; Campanha da Saúde Bucal, Campanha de Orientação Alimentar.

${ }^{207}$ Fonte: Jornal Entreposto, fevereiro de 2004.
} 
7- Em todos os pavilhões AP'S deveriam ser feitas faixas como foram feitas no pavilhão APC.

8- Está existindo comercialização de mercadorias em cima de carrinhos e de palletes no pavilhão MFE-B e nas ruas, que a fiscalização possa subir na plataforma.

9- Todos os carregadores autônomos trabalham só com carrinhos cinzas, seria melhor para identificar os clandestinos e os funcionários registrados.

10- Uma segurança mais ofensiva a respeito do trânsito, devido ao excesso de velocidade que está podendo causar acidentes graves, pois, já houve vários acidentes por causa deste excesso". (Jornal Entreposto, fevereiro de 2004).

Nesse documento identificamos um conjunto de reivindicações como a retirada dos clandestinos, bem como melhorar a circulação de veículos, cujo congestionamento afeta a circulação do carregador e a alta velocidade ocasiona acidentes, aumentar o número de fiscais e mudar as estratégias de atuação, melhorar a conservação das vias de circulação, melhorar a segurança e, para isso, padronizar os uniformes e os carrinhos.

A questão do carregador clandestino na CEAGESP já aparecia em 2001, na imprensa local, como um velho problema, pois eles são considerados aqueles que vêm "tomar o serviço dos carregadores, acabam cometendo furtos, e comprometendo a imagem da categoria como a do entreposto" 208 , segundo as palavras do diretor do Sindicato. Face aos índices de desemprego que a metrópole apresentava naquele período, aumentava a entrada no Terminal de pessoas procurando uma possibilidade de trabalho "fácil"; assim a concorrência se acirrava. O confronto do trabalhador regulamentado com o clandestino é contínuo, e este vê suas possibilidades de ganhos diminuírem diante da ampliação de oferta de mão-de-obra. Dessa maneira, a reivindicação do Sindicato ganha contornos de demarcação de território de trabalho, criando fronteiras junto com a administração da Companhia, delimitadas e fechadas, em relação a essa possibilidade de trabalho, que tende a reduzir-se com a modernização.

Em julho de 2005 aparece no quadro do SINDCAR, uma conclamação para que os carregadores regulamentados denunciassem os clandestinos, procurando a fiscalização ${ }^{209}$, sem precisarem identificar-se. E o texto encerra-se da seguinte forma: "Se preferir, pode pedir orientação do Sindicar, pois um sindicato forte garante o trabalho de todos os carregadores e o sustento de seus familiares". 210

\footnotetext{
${ }^{208}$ Fonte: Jornal Entreposto, novembro de 2001.

${ }^{209}$ Atualmente, a fiscalização conta com 62 fiscais para o controle dos portões e circulação no espaço interno, revezando em turnos.

${ }^{210}$ Fonte: Jornal Entreposto, junho de 2005, $\mathrm{n}^{\circ} 61$
} 
Vejamos a carta do Sr. Francisco Antonio de Souza, carregador há 32 anos no Entreposto e diretor do Sindicato, que foi publicada no Jornal Entreposto, em agosto de 2005, na seção do SINDCAR:

[...] a culpa é da fiscalização que permite o livre trabalho do carregador clandestino, permite na CEAGESP a entrada de carrinhos de mão e de carrinhos de ferro que não só tiram o trabalho do carregador autônomo como também por não terem de prestar contas a ninguém estes carrinhos são largados em qualquer lugar atrapalhando inclusive o estabelecimento dos caminhões.

Os carregadores reclamam também do afrouxamento da fiscalização, os guardas estão permitindo aos carros pequenos e os utilitários que deveriam ficar nos estabelecimentos próprios para estes veículos, entrem na CEAGESP e circulem livremente entre os pavilhões carregando diretamente dos boxes e caminhões, atrapalhando a circulação dos carregadores, também estes veículos utilizam o estabelecimento destinado aos caminhões, assim vindo a tumultuar as condições de trabalho de todos na CEAGESP.

O sindicato conclama a categoria para defender o seu trabalho e pôr um fim de uma vez por todas nesta situação, que só contribui para degradar as condições de trabalho dos carregadores autônomos regulamentados. (Jornal Entreposto, agosto de 2005)

Em setembro e outubro de 2005, as manifestações contra os carregadores clandestinos continuaram a aparecer na imprensa local no espaço destinado ao Sindcar:

Sindicar reivindica combate ao carregador clandestino [...] coibir a ação dos clandestinos que a cada dia aumenta.[...]com isso, os carregadores regularizados e os sócios achavam que nosso sindicato não estava preocupado com o desemprego que a ação dos clandestinos acarretam para os trabalhadores autônomos e isso não é verdade"[...] Invasão dos clandestinos. (Jornal Entreposto, setembro de 2005)

No fim de 2005, uma antiga reivindicação das categorias de trabalhadores da Companhia é atendida pela direção da CEAGESP e se cria o Conselho de Entidades Representativas dos Permissionários e dos Trabalhadores do Mercado, isso passa a possibilitar um maior diálogo entre as entidades e a direção da Companhia.Vejamos o que diz o presidente do Sindicato em entrevista:

Zé: A maior tristeza que tem é o camarada não levar, chegar em casa e não levar dinheiro para o sustento dos filhos e já tem acontecido disso, algum carregador não levar. Então, isso dói na pessoa, porque ela chega em casa e dizê "Pai, eu quero leite, arroz, ..." e não tem para ele dar. Eu acho que não tem dó pior, não, só se for a morte, mas isso aí.

\section{S:Catadores pedem auxílio?}

Zé: Alguns pede [...]É uma coisa meia triste prá gente.. 
S:Tá aumentando, cada vez?

Zé: Não. Certo tem sustentado...aculá aparece algum. Nem tanto carregador aqui, é pessoas que vêm de fora e que vem pedi emprego aqui, é uma coisa absurda. Então o camarada chegar e dizer 'rapaz me vê um emprego, pelo amor de Deus, que eu não deixei nada em casa pra meus filhos.' Chegou um dia, um aqui eu ofereci almoço prá ele, ele disse que não queria, não que os filhos dele tá passando fome, e aí gente vai conta que aqui não é assim, que quem tá aqui já não tem emprego, aí eu mandei dar uma cesta básica pra ele. Aí ele disse 'Agora eu vou comer, levar para os meus filhos'.

S: Se uma pessoa quiser entrar?

Zé: Não entra porque não tem vaga. Porque os tá aí, metade tá parado.

S: Esgotou?

Zé:Esgotou.

S:O sistema é não deixar trabalhar?

Zé: Não deixa entrar, se entrar é mais um parado, já tem um monte parado. Se entrar mais outro, fica mais outro parado.

S: Conterrâneo?

Zé :Não tem, porque não tem serviço. Mas sempre tá vindo.

S: Tá chegando gente do Nordeste?

Zé: Não, agora não, parou um pouco, mas vinha bastante. Aí a gente começou a dizer [...] pessoal que não viesse, que não tinha serviço aqui. Aí manero mais.

Outro dado que revela a territorialidade desse grupo de trabalhadores é o acordo estabelecido entre a Companhia e o Sindicato, proibindo a entrada do "chapa" de Caminhão, que representa mais um concorrente e, portanto, diminui a renda do carregador cadastrado.

Outro depoimento expõe estas relações de concorrência, superando a iniciativa de organização e união que o Sindicato procura construir para esses carregadores em um contexto de progressiva redução do mercado de trabalho no Terminal. Vejamos esse relato:

Tem carregador que faz mais barato para pegar a freguesia, porque é mais barato que o outro. Por acaso, eu vou trabalhar para você. Aí, você me paga $R \$ 250,00$ por um caminhão. $O$ outro chega aí e diz 'Se você pagar $R \$ 150$, eu vou.' a ai estraga. Agora mesmo, deixamô mesmo um caminhão de melão de descarrega, de Mossoró, segunda-feira e às vezes é na quantafeira, também, duas vezes. A tabela dela é de $R \$ 0,27$ e o japonês queria pagar pra nós $R \$ 0,20$. Aí, nós falou, se não pagar a tabela, não descarrega, Aí vai outro e pega e vai a 20 centavos, porque não queria pagar a tabela. Aí, nós conversa com ele, toma a tabela, vê a tabela com a gente. Aí quando chega lá, não quer pagar a tabela não. Aí veio outro, vai lá e pega. É difícil. (Jessé) 
O depoimento de Jessé também registra a falta de união dentro da categoria, confirmando que isso já aconteceu com ele: um colega roubou o seu serviço, acabou prejudicando o seu trabalho.

\subsubsection{O clandestino, o trabalho infantil e a Escola Nossa Turma}

Um dos carregadores relatou que chegou para trabalhar nos anos 70, que veio a partir de uma informação de um conhecido que tinha retornado para a sua cidade, e dizendo que o CEASA $^{211}$ era bom lugar para se trabalhar. Assim, chegou sem cadastro e foi trabalhando até conseguir uma vaga como cadastrado. Vejamos o que diz:

\section{C:Trabaiando, trabaiando e o fiscal em cima, ia preso. \\ S: O senhor era clandestino? \\ C:É lógico que era... naquele tempo... até conseguir. \\ S: O que os fiscais faziam na delegacia?}

C:Levava pra lá e depois soltava na mesma hora, não era bandido, né? Era quase todo dia... Ixe!! Quase todo mundo aqui... quase todo mundo ia... levava pra lá, só que não ia preso, ficava lá só pra., no outro dia, nós estava tentando de novo. (Francisco)

Nessa fala podemos perceber que uma parte dos carregadores hoje regularizados já esteve um dia em uma situação de clandestinidade. Hoje, não existe identidade entre esses trabalhadores regulares e os irregulares, mas uma situação de competição e controle do território pelo cadastrado.

O trabalhador, enquanto mercadoria, é constitutivo da circulação de economia urbana. Essa transformação do carregador, de clandestino para regular, é um processo cheio de contradições. Como clandestino, ele briga para se regularizar, depois de regularizado, ele luta contra a presença do clandestino. Esse processo da manifestação do trabalho clandestino ocorre desde os primórdios do Entreposto, mas as relações de conflito se explicitam à medida que ocorre a redução da oferta de trabalho.

Hoje em dia, o clandestino não é necessariamente aquele que vem de fora. Muitas vezes são os próprios empregados dos boxes que fazem um extra, "bico", para complementar

\footnotetext{
${ }^{211}$ Denominação do Entreposto naquele período,e permanece até hoje no senso comum.
} 
a renda, tirando o trabalho do carregador autônomo. ${ }^{212}$ Isso é possível reconhecer pela cor do carrinho, pois o carregamento do feirante que é feito por carregador de carrinho amarelo deveria ser realizado pelo carregador de carrinho cinza, há também o uniforme que os identifica. No acordo do Sindicato com a Companhia, o empregado do box pode trabalhar apenas na plataforma, tendo delimitado os espaços de trabalho e imposto um território aos carregadores; assim o empregado pode descarregar, mas não pode distribuir, restringindo a sua circulação no espaço interno. No entanto, o empregado do box, assume uma determinada clandestinidade, cobram um preço inferior ao carregador autônomo para disputar trabalho.

Outra situação recorrente é o carregador regulamentado trazer seus conhecidos, conterrâneos, para lhe auxiliar, esperando a possibilidade destes conseguirem ser cadastrados. Vejamos a declaração de outro carregador sobre carregadores não regulamentados:

Os chapas tão aqui dentro. Os chapas... por exemplo, o cara chega e diz assim :'O mercado tá bom, o mercado tá ótimo!', ai o cara fala: "O rapaz, me arruma um biquinho?'. Os próprios conterrâneos é que traz, é que traz, eles é que traz. Às vezes, pega um serviço, sei lá... Aí eu falo: Vai lá me ajudar, eu te dou 20 (vinte reais). ( Sr. Mateos)

Outra explicação sobre o trabalhador clandestino, de um carregador cadastrado e permissionário:

Você trabalha aqui, aí tem teu filho que tá com quinze, dezesseis anos, dezoito anos e tá um pouco difícil de arrumar serviç, fora, aí ele vem pra cá ajudar o pessoal que trabalha aqui. Aí, ele vem com o pai. Chegou um irmão do Piauí, aí até tirar documento de carregador, aí eles ficam aguardando, esses são os clandestinos. Alguém que tira o documento e deixa vencer, vai pro Piauí, deixa vencer, quando volta ele vai trabalhar aqui, a autorização dele tá vencida, então ele... clandestino. (De Paula)

Esse processo de agenciamento é muito comum no setor de melancia e abacaxi, pois o serviço é mais demorado e só se consegue fazer por dia um caminhão que transporta o produto a granel. O carregador credenciado normalmente tem o cliente certo e não se dispõe a executar essa tarefa, então agenciam-se iniciantes.

Vejamos outro depoimento que mostra a relação de amizade entre o regulamentado e o clandestino:

Indiquei um amigo da gente que era clandestino e precisava trabalhar. E hoje cada um tem um modo de pensar, quando tem... a gente tem que pelo menos olhar pelo ser humano, um pouco sabe? E ele precisava trabalhar,

\footnotetext{
${ }^{212}$ No setor do pescado, os carrinhos vermelhos identificam os funcionários de feirante, que dispensa o trabalho do carregador, significando a perda de um território de trabalho. Eles contam que já fizeram reunião com a Companhia para recuperar essa possibilidade de serviço, mas avaliam que é irreversível essa situação.
} 
então ele falou, pediu. Aí eu arrumei e pedi uma vaga prá ele e concederam essa vaga pra ele... Já faz uns oito anos. (João)

Em outro momento da entrevista, o mesmo carregador diz - "Todo mundo precisa trabalhar, não vou discutir com ninguém. O problema é que a gente paga, [...] então não é justo [...] de vez em quando aparece, mas a gente luta pra ir pra cima”.

Esses fragmentos da entrevista, além de permitir o entendimento da presença dos clandestinos, nos auxiliam a compreender a formação da rede social. Assim, os clandestinos não são estranhos na comunidade, pois eles são os próprios conterrâneos, componentes da rede social. A redução do mercado de trabalho tornou constante a presença simultânea da solidariedade e do conflito, estreitando laços de conterrâneidade e ao mesmo tempo, os arrebentando.

As práticas de solidariedade são lembradas nos depoimentos, quando um carregador não tem dinheiro para se recadastrar os seus colegas fazem uma coleta de dinheiro e cada um contribui com um real ou dois, ou então quando um carregador se machuca ou adoece, essas ações se repetem, no sentido de ajudar o colega que está impossibilitado para o trabalho.

Nos dias da feira das flores encontra-se uma maior presença de carregadores clandestinos. Eles se apresentam como jardineiros e depois oferecem o serviço de carregador, muitas vezes, "agenciando" o trabalho dos carregadores cadastrados. Eles cobram $\mathrm{R} \$ 15,00$ do comprador, ficam com $\mathrm{R} \$ 5,00$, e dão ao carregador o preço que é cobrado na 'tabela', $\mathrm{R} \$ 10,00$.

Observamos em campo, que, na verdade, grande parte desses clandestinos é constituída por crianças e adolescentes, sem carrinhos, que apenas oferecem a sua força de trabalho. O trabalho infantil sempre foi um problema para os carregadores, pois significa mais um concorrente. Assistimos, na feira de flores, uma competição entre o trabalho infantil e o trabalho do idoso, já que é o local em que se concentram os carregadores mais velhos. Essas crianças e jovens apresentam uma diversidade de idades, e sem carrinho, se sujeitam a carregar as flores nos braços. Existe uma preocupação entre os carregadores com relação a essas crianças e jovens, que aparecem de forma competitiva, desarticulando a organização dos carregadores, os preços dos fretes e outras regras estabelecidas pela categoria.

Zé:Aí é o CEASA. Nós temos problema dessa garotada. É um problema sério. Essa garotada se (inaudível...) dos vizinho (...já vira)Porque tem a lei, também, que a criança não pode tá em local de serviço. Se topa ali criança com 10, 12 anos com torrão monstro nas costas, chega a ficar (vesgo) ali com torrão nas costas. [...] (permissão de) não entrar aqui.

\section{S:.Tem a fiscalização?}




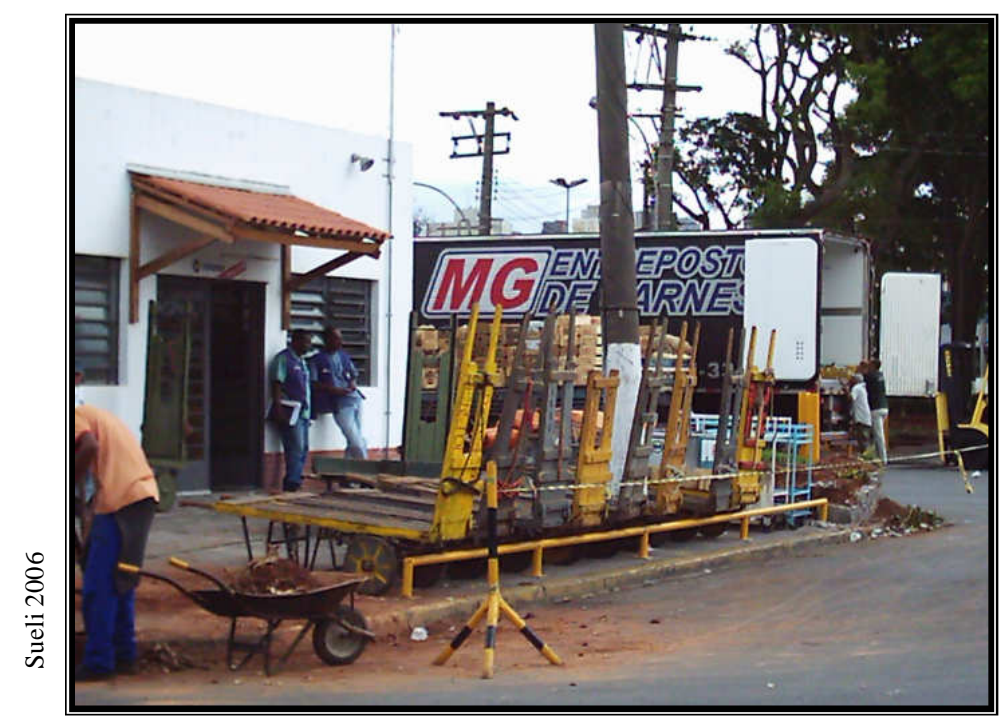

Foto 34: Carrinhos aprendidos no posto da fiscalização.

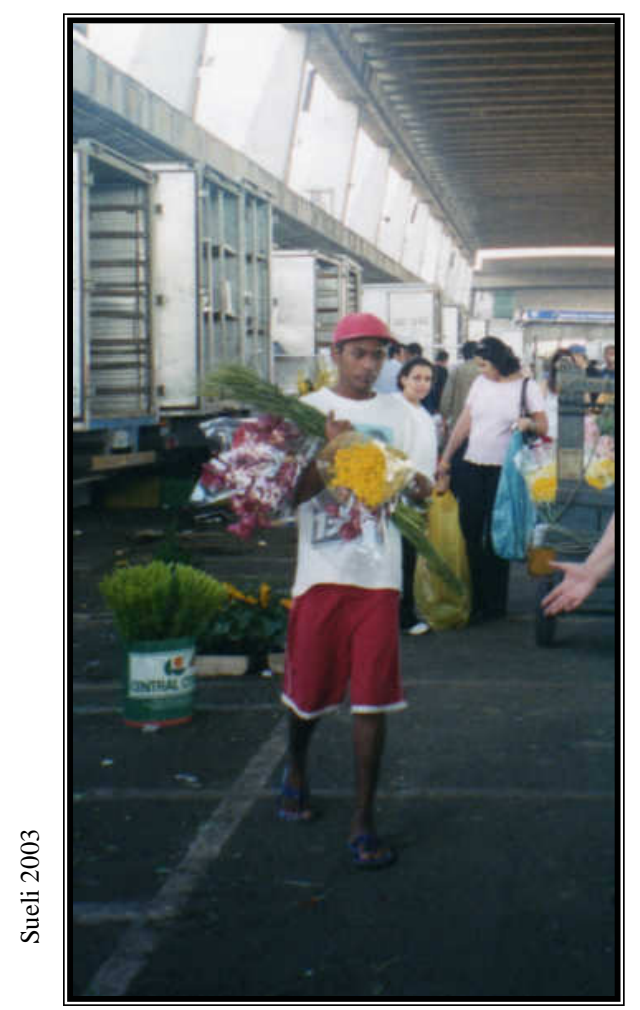

Foto 35: Carregador Clandestino menor de idade na Feira das Flores no Terminal da CEAGESP. 
Zé: Tem a fiscalização, mas ela não é feita, ela não atua como é prá fazê,, ela é cheio de direito, ninguém pode triscar nele. Ele pode roubar, ele pode matar, ele pode fazer o que quiser, não tem... e é um grande problema para o carregador, isso aí."... "Mas aquela garotada uns vem 'trabaia' e o outros é roubar, e os que vem trabaia, até tem, mas e os que vem roubar? $O$ problema é do carregador. [...] Até de carregador eles rouba, carregador que chega aí chorando, pega a mercadoria da pessoa, eles 'rôba' e a pessoa faz o carregador pagar mercadoria. Tira vaso do carrinho. O cara vai puxando o carrinho e não olha atrás. E ele tira planta cara, de $R \$ 80,00$ ou $R \$ 100,00$ real que eles tira. É, eles conhecem. (Zé Pinheiro)

A preocupação pela presença forte do trabalho infantil na CEAGESP faz parte das discussões do Sindicato com a Administração da Companhia. Dessa forma, em março de 1998 foi criada a Escola Nossa Turma, no espaço interno da Companhia. Uma iniciativa do Sindicato $^{213}$, junto à Administração para atender as comunidades do entorno do Entreposto: a população das favelas e do conjunto habitacional. Hoje, essa iniciativa é reconhecida por toda a comunidade da CEAGESP.

A Escola Nossa Turma atende 543 crianças, moradores do conjunto habitacional Cingapura e das favelas (Maderit, Parque São Domingos e Continental). Essas crianças têm de 4 a 16 anos. A escola está na área interna da Companhia e a diretora da escola é registrada como funcionária da CEAGESP. A iniciativa vive de doações para pagar os professores e a manutenção da escola. Além da pré-alfabetização (método montessoriano e contrutivismo), também, há a escola de futebol, os curso de capoeira, de artes e informática, sendo que essa última oficina tem o apoio de um programa ligado ao Banco do Brasil. Lembrava o Prof. Magno Oliveira, em entrevista de julho de 2001: "Todos esses adolescentes moram perto da CEAGESP, foram criados aqui e têm uma intimidade muito grande com o mercado”. O artigo para o Jornal Entreposto tratava da inserção dos adolescentes da Escola Nossa Turma, maiores de 16 anos, que estavam sendo contratados pelos atacadistas do Terminal.

\subsection{A modernização no abastecimento da metrópole}

O sr. Mateos, carregador de 68 anos, conta que em 1972 chegava a carregar até 5 caminhões por dia. Hoje, com a escassez de serviço, carrega apenas um. Ele, ao seu modo, mostra as consequiências da diminuição de centralidade do Terminal no abastecimento alimentar ao longo do tempo. Veja o seu relato: "Eram 5 mil e pouco carregadores, hoje é 4 mil e pouco. O resto morreu, outros foram embora, o resto tá voltando."

\footnotetext{
${ }^{213}$ Uma iniciativa em especial de Manoel da Silva Filho, o Manelão.
} 
Os dados sobre o fluxo de mercadorias daquelas décadas iniciais da Companhia, segundo a Seção de Economia e Desenvolvimento da CEAGESP se perderam com as diversas enchentes que tomaram por varias vezes a área do Terminal. Assim, obtivemos dados referente apenas a partir de 1989, informações que mostram um declínio na década de 90, conforme registram os depoimentos, e uma pequena recuperação nos últimos anos. Vejamos a tabela que segue:

Tab. 9:

\begin{tabular}{|c|c|c|}
\hline \multicolumn{3}{|c|}{ Volume Comercializado em Toneladas } \\
\hline Ano & Toneladas: & (\%) Base de 1989 \\
\hline 1989 & 2.849 .165 & 100 \\
\hline 1990 & 2.869 .524 & 100,8 \\
\hline 1991 & 2.890 .448 & 101,6 \\
\hline 1992 & 2.593 .893 & 91,1 \\
\hline 1993 & 2.612 .758 & 91,8 \\
\hline 1994 & 2.642 .299 & 92,8 \\
\hline 1995 & 2.724 .949 & 95,7 \\
\hline 1996 & 2.572 .088 & 90,4 \\
\hline 1997 & 2.627 .672 & 92,3 \\
\hline 1998 & 2.492 .491 & 87,6 \\
\hline 1999 & 2.481 .850 & 87,6 \\
\hline 2000 & 2.686 .604 & 94,4 \\
\hline 2001 & 2.777 .020 & 97,6 \\
\hline 2002 & 2.737 .894 & 96,2 \\
\hline 2003 & 2.688 .974 & 94,5 \\
\hline 2004 & 2.795 .386 & 98,2 \\
\hline 2005 & 2.913 .032 & 102,3 \\
\hline 2006 & 2.957 .110 & 103,9 \\
\hline
\end{tabular}

Fonte: Seção de Economia da CEAGESP (2006). 
A tabela do Volume Comercializado em Toneladas registra a diminuição do volume movimentado de mercadorias; em a variação percentual no período chega em 1999 a 87,2\% do volume total que se comercializou em 1989, o que implicou teve reflexos na quantidade de trabalho para os carregadores, que foi reduzida acentuadamente.

O chefe da seção de Economia e Desenvolvimento, Flávio Godas, atribui o crescimento, não só de volume mas também financeiro, que ocorreu nos últimos dois anos, principalmente às vendas de produtos que têm maior valor agregado, como nectarinas, pêras, uvas, ameixas, cerejas, linchias, produtos exóticos; estes são produtos importados e sua comercialização foi estimulada pela queda do dólar dos últimos anos. ${ }^{214}$

Nos anos 70, havia uma maior centralização do comércio no Terminal, pois até então, não havia tantos CEASAS no Estado e no território brasileiro, o que favorecia um aumento na oportunidade de trabalho para os carregadores. A criação de outros CEASAS espalhados em várias partes do estado e do país diminuiu a importância relativa do Terminal e por fim, o fator fundamental, na redução do comércio do Terminal foi a metarmorfose nas relações estruturais de circulação da mercadoria-alimento, ao qual consideramos relevante discutir nessa pesquisa.

\subsubsection{A reestruturação na circulação dos produtos alimentícios}

Em sua pesquisa sobre feiras livres, no município de São Paulo, Olmária Guimarães(1969) registra, nos dados referentes ao ano de 1964, a presença de 452 feiras por semana, envolvendo 12.675 feirantes, sendo que sua população era de 5.383 .265 habitantes. $^{215}$ Em 1976, as feiras ampliaram-se para 563 por semana com 10.978 feirantes, conforme registro de Silvana Pintaudi (1988). Ao longo dos últimos dez anos, o número de feiras livres no Município de São Paulo permaneceu estagnado. Em 1994, para uma população de 9,86 milhões de habitantes havia 904 feiras na cidade. No ano de 2005, para 10,68 milhões de habitantes, a prefeitura registra 905 feiras livres. No mesmo período, o total de supermercados saltou de 586 para 799. Em 2007, a Secretaria do Abastecimento de São Paulo registra o número de 886 feiras livres no município, indicando um processo contínuo de redução da feira livre. ${ }^{216}$

\footnotetext{
214 Ver no anexo tabela dos últimos dois anos sobre o fluxo financeiro e de volume comercializado na Companhia (ou Entreposto).

${ }^{215}$ Dados da população de 1967, conforme registra Olmária Guimarães (1969).

${ }^{216}$ O Município de São Paulo, por sua dimensão, é um bom indicador de todos os 36 municípios que compõem a metrópole, sobre a redução das feiras. Por isso, ele nos serviu de referência para esse desse processo de redução
} 
A redução do número de feiras livres e do seu papel no abastecimento alimentar é uma conseqüência do aumento do número de supermercados se inserindo no setor de hortifrutigranjeiros. Ao longo da década de 90, a participação da venda de alimentos desse setor nos supermercados passou de 30\%, em 1990, para 75\%, em 2000.217 Vejamos o depoimento do atacadista Mario Benassi:

Os supermercados, até uns quinze anos atrás, não sabiam trabalhar com frutas e verduras, agora, ultimamente eles aprenderam e eu tenho um pouco de culpa nisso aí, no ano de 86, comecei a atender o Pão de Açúcar, eu comecei atender uma loja e meus funcionários colocavam a fruta $e$ arrumavam e o trabalho foi evoluindo. Eu comecei com uma loja e hoje só na cidade de São Paulo, tem mais de 80, o Pão de Açúcar.Frutas minhas... meus clientes, então, dou atendimento especial, como o feirante fazia antigamente e o supermercado com ar condicionado, tem alguns que tem até manobristas e ninguém vai na feira, então a feira vai caindo.

O modo de vida na metrópole altera as formas do cotidiano das pessoas, modifica os horários dedicado às compras e dificulta a cultura de se "fazer feira". Atualmente, os hábitos familiares em relação ao abastecimento modificam-se. No dia-a-dia, os hipermercados funcionam 24 horas, e o tempo livre das pessoas é usado para o consumo; - ir ao hipermercado se transforma em lazer familiar, pois o tempo livre é usado para o consumo ${ }^{218}$. Nas grandes redes de supermercados encontramos lanchonete, cafeteria, espaço de recreação para as crianças e outras atividades comerciais, o que evita que as pessoas circulem tanto pelas cidades, já que procuram então suprir suas necessidades em um único local.

As mudanças na comercialização de alimentos também passam pelas formas de pagamento. Os feirantes, os mercadinhos e as mercearias tinham com os seus fregueses o "fiado" como pratica comum, pois eram mais sólidas as relações de confiança. Até a década de 1970, ainda era usual nas mercearias e mercados a caderneta, em que o consumidor acertava, as contas no dia do pagamento de seu salário. Essas relações foram desaparecendo e sendo, aos poucos, substituídas pelo "fiado eletrônico". Entram os cartões de crédito que dão garantias aos comerciantes sobre a venda realizada. $\mathrm{O}$ que acontece nesse processo é o endividamento do consumidor com o sistema financeiro para comprar a sua alimentação. Deste modo, em tempos de modernização, o freguês virou cliente! Assim, a facilidade de comprar um produto hortifrutigranjeiro tornou-se maior no supermercado, do que na feira livre com o papel moeda, nem sempre disponível nos bolsos dos consumidores.

\footnotetext{
das feiras. Segundo a pesquisa do CQH (Controle de Qualidade de Hortifrutigranjeiros) da CEAGESP, 66,67\% das compras são destinadas ao Município de São Paulo.

${ }^{217}$ Os dados são do IFPRI (Instituto Internacional de Pesquisas Políticas Alimentares, Washington).

${ }^{218}$ Sobre a racionalidade do tempo e dos hábitos dos indivíduos, ver "A vida cotidiana no mundo moderno", Henry Lefevre (1991[1968]).
} 
Milton Santos, ao tratar do comércio varejista moderno, inclui as grandes redes de supermercados como o circuito superior e, já em 1979, em sua obra Espaço Dividido (2004), menciona a expansão dessas redes nos países subdesenvolvidos. Vejamos:

Sua existência está ligada à possibilidade de uma demanda mais numerosa e mais diversificada, assim como às possibilidades de pagamento em dinheiro líquido ou segundo as formas burocráticas de crédito, tais como cartões de crédito instituídos pelos bancos ou sistemas de crédito particulares a certas firmas comerciais. As relações são impessoais nesse gênero de supercomércio. É por isso que o número de supermercados varia principalmente em função da importância das classes médias e do número de assalariados, enquanto sua dimensão é função dos bairros ricos. (SANTOS, 2004:87)

Nesta mesma obra, o autor faz referência à rápida destruição nos países subdesenvolvidos dos hábitos tradicionais, principalmente em relação ao ramo dos alimentos, quando instalada a publicidade a serviço das sociedades. ${ }^{219}$

Normalmente, os preços nas feiras são superiores aos dos hipermercados, que conseguem negociar preços melhores que os dos feirantes, pois compram quantidades maiores. Esse jogo comercial fez com que uma parte dos feirantes quebrasse e fechasse a sua banca.

Em abril de 2001, o Jornal Entreposto publicou uma matéria em que colocava uma grande questão: "Por que as grandes redes de supermercados se afastaram da CEAGESP?". O vice-presidente da APAS (Associação Paulista de Supermercados), Sussumu Honda, atribuía a causa dessa situação, nesse artigo, à falta de padronização dos produtos e á ausência de uma logística que pudesse atender as necessidades dos supermercados. A caixa $\mathrm{K}$, por exemplo, é uma embalagem condenada, do ponto de vista da conservação e higiene dos alimentos, pois gera grande desperdício, ainda é encontrada na Companhia, afastando as grandes redes de supermercados.

No entanto, os mercadinhos ${ }^{220}$ cresceram, segundo dados da ACNielsen ${ }^{221 .}$ Eles participavam dos 35,9\% do faturamento global do setor no país, em 2001; já em 2003, eles ampliam a participação para $38,3 \%$ das vendas. Os hipermercados, que faturavam 18,8\%, declinam para 16,2\% de participação nesse setor, no mesmo período (F.S.P 25.04.2005). Vejamos a análise que a Coordenadora do Controle de Qualidade em Horticultura da CEAGESP traça, em artigo publicado no jornal interno e em entrevista para nossa pesquisa:

\footnotetext{
${ }^{219}$ SANTOS, 2004:145.

${ }^{220}$ Os mercadinhos são estabelecimentos comerciais que apresentam de um a quatro caixas.

${ }^{221}$ Empresa de Pesquisa de Mercado que atua em mais de cem países. Sua sede está em Nova York e ela atua desde 1970 no Brasil. Sua sede está localizada em Cotia (G.S.P.); site: www.acnielsen.com.br
} 
À década de 90 houve um grande declínio do número de compradores, pois foi o período que as grandes redes de hipermercados montaram as suas próprias centrais de compras. No entanto, o surgimento das pequenas redes de bairro e o salto da importância das frutas, legumes e verduras para os supermercados trouxeram um contingente maior desses clientes para o Entreposto. (Anita de Souza Queiroz) $)^{222}$

Outra declaração:

As grandes redes estão fazendo supermercados, também, próximos. No tempo de inflação, elas tinham razão de ser ou você gastava seu salário rapidamente, senão você tava frito. Pelo modelo de ocupação urbana que tem no Brasil, não tem lógica. Nos Estados Unidos todo mundo mora longe, as pessoas saem de carro pra tudo, mas no Brasil, mora perto, a menos que seja Alphaville. Você quer comprar perto de casa, que é a lógica. Você chega em casa, passa ali compra alguma coisa e vai pra casa. (Anita)

As grandes redes de supermercados montaram as suas próprias plataformas de distribuição para comprar direto do produtor. No entanto, elas ficaram. em parte, ociosas, pois alguns tipos de produtos necessitam de manuseio. Atualmente, eles compram parte dos produtos diretamente dos produtores; uma outra parte ainda recorrem ao Entreposto, principalmente produtos mais exóticos, de menor volume; para uma terceira parte, recorrem a atacadistas fora da CEAGESP: "As coisas então entremeadas dependendo do produto" (Anita Gutierrez). Não podemos generalizar, então, que as grandes redes compram apenas do produtor no que se refere aos hortifrutigranjeiros, existe uma diversidade de elos nesse circuito, que se tornou mais complexo e que merece uma pesquisa à parte.

A pesquisa realizada em 2005 pelo CQH (Controle de Qualidade em Horticultura/ CEAGESP) aponta um novo perfil dos compradores. ${ }^{223}$ Enquanto em 2001, os feirantes representavam 44,6 \% dos compradores, em 2005 eles reduziram a sua participação para $31,55 \%$ dos compradores; já os supermercados, que representavam 10,9\%, ampliaram a participação para 19,43\%; por fim aparece uma categoria mais recente, que é a figura dos distribuidores com 19,07\%. Esses distribuidores são uma espécie de "terceirização" dos compradores; eles atuam e crescem entre os pequenos e médios mercados. Para Anita de Souza Dias Gutierrez, a mudança do horário, da madrugada para o diurno, contribuiu para o aparecimento dos distribuidores, pois o pequeno comerciante que antes comprava os seus produtos durante a madrugada, cuidava durante o dia do seu estabelecimento, atualmente, muitas vezes, ele delega essa tarefa das compras para os distribuidores, aumentando a

\footnotetext{
222 Jornal Entreposto, setembro de 2005, $\mathrm{n}^{\circ}$ 64, ano 6.

${ }^{223}$ O Centro de Controle de Qualidade em Horticultura da CEAGESP entrevistou 561 compradores no Entreposto Terminal de São Paulo no período de 26/04/2005 a 07/06/2005, num estudo coordenado por Anita de Souza Dias Gutierrez.
} 
intermediação entre o produtor e o consumidor final. Essa terceirização das compras dos hortifrutigrangeiros amplia os elos de negociação e aumenta o preço do produto final. A ampliação dos elos da cadeia a reordenaram os circuitos e a reestruturar as formas de trabalho que os compõem.

Acompanhando a tendência dos pequenos mercados, as grandes redes, estão implantando pequenos mercados. Um exemplo é a rede do Carrefour, que possui mercadinhos de bairro com no nome de DIA\%. O fechamento de algumas grandes lojas do Carrefour é um indicador desse processo. Esses são elementos importantes para entendermos como a modernização do abastecimento altera as relações de trabalho em que estão inseridos os migrantes, centro do nosso debate.

Outro aspecto importante que devemos considerar na circulação de mercadorias no Entreposto é que existem os atacadistas menos capitalizados e os mais capitalizados. Estes últimos conseguem atender as exigências das grandes redes de hipermercados e mantêm vínculos com esses grupos. Vejamos:

Os supermercados, eles compram direto dos produtores. Algumas vezes, os produtores vendem mais barato para o supermercados do que vendem aqui no CEAGESP. Então, isso atrapalha um pouquinho. Porque o produtor acha que se vender direto para o supermercado, ele ganha mais. [...] Aqui, vem buscar aqui, não vem quase nada, também. Hoje $70 \%$ da compra do Pão de Açúcar é feito direto pela Central...acredito que $25 \%$ ou quase $27 \%$ que eu entrego direto nas lojas,...saí do meu depósito (local instalado na Vila Leopoldina, próximo do Terminal da CEAGES, vai prá lá.Uma filial daqui que vai prá lá. Lá eu trabalho 24 horas por dia, atendendo a rede Cooper de Santo André, antigamente..., supermercado Modelo, de Cuiabá; atendo a rede $D B$ de Manaus, tudo na central de distribuição, e mais algumas lojas do Carrefour, algumas lojas do Wall Mart; os supermercados (inaudivel) têm 51 lojas aqui em São Paulo, eu atendo 100\% dele; o supermercado Cooper eu atendo 100\%; a rede ABC, lá em Santo André e 100\% a rede Molina de Cuiabá, atendo parcial supermercado Cooper de Campo Grande, Brasília e Cuiabá. (Mário Benassi)

O abastecimento ocorre em meio ao processo de racionalização do setor, o que impõe modificações no espaço em estudo, o Terminal. As alterações ocorrem, também, no modo de abastecer a metrópole e de circular a mercadoria-alimento. ${ }^{224}$ Cada vez mais as pessoas vão aos hipermercados e supermercados, e deixam de frequientar as feiras livres, conforme estudos de Cacciamali (1983) e Gaeta (1985) registraram.

\footnotetext{
${ }^{224}$ Não devemos esquecer que década de 90 também aparecem os centros atacadistas de gêneros alimentícios, promovidos pelo poder público do município de São Paulo e redes de Sacolões. Esse comércio realiza a venda e estabelece o preço por quilo de hortifrutiganjeiros. Essa forma, em princípio, o agricultor pode comercializar diretamente para o consumidor, sem a medição do Terminal de Abastecimento, quando gerenciado pelo poder público. Esse processo pode, também, ter contribuído para a diminuição da centralidade do Terminal.
} 
Os permissionários atacadistas do Terminal normalmente possuem seus próprios empregados, uma pequena parcela dos trabalhadores de lá. Então, o principal cliente que contrata os serviços do carregador é o feirante. O declínio das vendas desse comerciante, o feirante, gerou uma redução dos serviços dos carregadores, desencadeando uma maior competição entre eles e, portanto, uma maior demarcação de seu território.

Devemos traçar algumas considerações sobre a circulação da mercadoria no Terminal. Primeiro, apontar que estão aparecendo novos compradores, que antes eram insignificantes, há 15 anos, como os restaurantes por quilo, manifestando novos hábitos na alimentação de uma parte da população da metrópole, e as grandes redes de hotéis e restaurantes, que crescem, acompanhando o novo perfil da cidade de São Paulo ${ }^{225}$. Essas transformações na cidade acabaram ampliando a participação dos restaurantes e hotéis como compradores do Terminal, assim como a verticalização e a expansão de bairros nobres da cidade, estimula também o crescimento do mercado das flores, que cresce vertiginosamente. Mesmo com menor centralidade, o Terminal ainda mantém a sua importância pela diversidade de produtos e acaba atraindo compradores de diversos espaços do território nacional.

\subsubsection{Chegam as empilhadeiras e a busca da qualificação}

$\mathrm{Na}$ feira $^{226}$ que expôs as novas tecnologias em logística para as Centrais de Abastecimento estão presentes empresas como a Linde Empilhadeiras (Linde AG.), um dos maiores grupos do mundo; ela ocupa o primeiro lugar no ranking de equipamentos para a movimentação e armazenagem desde 1996. Fabricam-se empilhadeiras elétricas, à combustão, transpaleteiras, à prova de explosão, para armazenagem, transporte e seleção de fornecimento logístico. Nesta área consideram-se como critérios de avaliação a robustez, a ergonomia, o desempenho, os custos de operação e a manutenção. ${ }^{227}$ Assim as empilhadeiras estão chegando no Entreposto. Vejamos o que diz a imprensa local sobre esse elemento de modernização:

Embora não haja possibilidade de se descartar o trabalho dos carregadores para a carga e descarga de mercadorias no entreposto de São Paulo, alguns atacadistas começam a incorporar o uso de empilhadeiras mecânicas - nas áreas onde isso é possível para a otimização da logística. Para agrônoma

\footnotetext{
${ }^{225}$ Tema debatido no evento organizado pelo Departamento de Geografia sobre os 450 anos de São Paulo, que resultou na publicação Geografias de São Paulo, Editora Contexto, 2004.

${ }^{226}$ FEMETRAN (Feira dos Meios de Transporte, Movimentação do abastecimento agroalimentar), em maio de 2006).

${ }^{227}$ Fonte: Jornal Entreposto, maio de 2006.
} 
Anita Gutierrez do CQH (Controle de Qualidade do Hortifrutigranjeiro) a Companhia deve atrair empresas prestadoras de serviço que agilizem a movimentação da carga, como as que alugam empilhadeiras, além de incentivar a instalação de plataformas hidráulicas. Outra questão fundamental é a exigência do cumprimento das leis que induzem a mudança de embalagens e a adoção de método moderno de movimentação de carga que, por fim diferenciam os produtos comercializados na CEAGESP dos vendidos em entrepostos concorrentes. (Jornal Entreposto, fevereiro de 2006, $\mathrm{n}^{\circ} 69$ )

Conforme os depoimentos e a nossa observação de campo, há aproximadamente, umas dez empilhadeiras no Terminal. Em termos de participação, a primeira impressão, é de que o número é insignificante. Elas se concentram sobretudo no setor das frutas. Nos outros setores, encontramos mais os pallets mecânicos, hidráulicos, que produzem o mesmo efeito que a empilhadeira no que se refere à substituição da mão-de-obra em razão do avanço tecnológico, levando a um maior índice de desemprego entre os carregadores. Como explica seu Zé Francisco: "Serviço que fazia com cinco homens, hoje faz com dois". Esses equipamentos que possibilitam maior velocidade de circulação de mercadorias, representam ainda um estorvo para o carregador, pois eles possuem uma largura que muitas vezes impede a passagem nas plataformas e nas ruas estreitas dos carregadores e atrasando o seu carreto. Cada equipamento desse substitui quatro ou cinco carregadores.

Mezgravis (2006) realiza um estudo dos chapas e do seu papel no meio técnico científico, e encontra entre eles um processo semelhante acerca da introdução de novas tecnologias do setor logístico, como os pallets e empilhadeiras. Para isto recorre a outros estudos, como o de Roberto França da Silva Junior $(2004)^{228}$ :

Estes objetos técnicos são recursos que 'padronizam' os modos de estocagem e de transportes, determinam formas específicas de trabalho humano em grande parte dos processos com o uso de empilhadeiras e operadores destas, sendo estes trabalhadores muitas vezes contratados das próprias empresas, dispensando os 'ajudantes gerais'(...)Este processo de operacionalização de cargas busca atender a uma necessidade das empresas e operadores de segurança (reduzir a um nível mínimo de perdas e avarias dos produtos) e velocidade no cumprimento dos prazos estabelecidos (o "just-intime"), especialmente o desafio de superarem distâncias. (JUNIOR, apud. MEZGRAVES, 2004:128) ${ }^{229}$

No caso de nossos estudos, a implantação das empilhadeiras e dos pallets, que potencializam o trabalho da circulação, encontra barreira na estrutura física do Terminal, e depende de grandes investimentos do Estado, para que sejam realizadas amplas reformas no

\footnotetext{
${ }^{228}$ Dissertação de Presidente Prudente (UNESP).

${ }^{229}$ Apresentou resultado de pesquisa na GT Trabalho no ENG em João Passoa.
} 
espaço físico para elas possam circular e realizar a carga e descarga. ${ }^{230}$ Assim sendo, com o atual espaço reservado à circulação na área interna do Terminal, o carrinho ainda é mais ágil e versátil, com maior velocidade, principalmente para os carregadores transportarem a caixa $\mathrm{K}$ (de madeira), considerada, já lembramos, como uma embalagem que, pelas exigências do mercado, tende a entrar em desuso.

Mario Benassi, atacadista do setor das frutas, está no Terminal desde os seus primórdios. No início, utilizava apenas o serviço do carregador autônomo, depois passou a ter seus próprios empregados e ainda mantém o serviço de dois carregadores autônomos, que estão com ele desde os anos 70, segundo a sua fala, "por consideração [...] Alguma parte da descarga, eu deixo para eles sobreviverem, eram muito antigos.” Em entrevista, lembra que foi o primeiro a implantar o sistema de empilhadeira, em 1993. Ele nos relata o episódio:

Eu tive muita pressão pelos carregadores autônomo, porque eles achavam que eu tava tomando o serviço deles. Hoje, por exemplo, toda a mercadoria que eu consigo trazer paletizada é bem mais prático pra mim. Eu demoro em torno de quinze minutos, vinte minutos, no máximo, pra descarregar uma carreta com 24 pallets ou 28 pallets. Se for manual, uma carreta demora 6 a 7 horas e bate muito mais a fruta, menos desperdício, estraga menos fruta. Porque a fruta chega... ganha tempo e velocidade.

Vejamos a continuação de seu relato:

No começo, me estragavam bastante a minha empilhadeira [...] Arrancavam fio, cortavam fio; era na calada da noite. A gente punha guardas, aqui, ele ficava encostado, aí, mas três por noite... tinha que chamar o eletricista pra fazer... não era todos os dias, mas uma vez por semana. (Mario Benassi)

Outros tipos de pressão vinham por parte da administração, que alegava a periculosidade que o veículo oferecia, segue o seu depoimento:

É perigoso? É, sem dúvida! Então quando eu comecei aqui no CEASA, andava muitas carrocinhas, aqui, não podia, não pode entrar carreta, porque é perigoso uma carreta! Tá modernizando, tem que modernizar! O CEAGESP pressionado a proibir, junto com o sindicato, colocaram área definida pra trabalhar com empilhadeira, (hoje não pode) entrar no pátio, não tem problema nenhum. Se fosse [...] não ia modernizar de jeito nenhum. Eu não ando com empilhadeira aqui dentro.

O movimento de um grupo de carregadores que se reuni para quebrar as empilhadeiras, remonta às características do movimento dos luddistas, no início do século XIX, que confundiram a máquina com a aspiração do proprietário da máquina, partindo para a

\footnotetext{
${ }^{230}$ Em 30 de novembro de 2006 realizamos trabalho de campo com estudantes da UNESP de Ourinhos, em um dos fiscais da Companhia que nos acompanhou nos confirmou sobre as condições de trabalho em que as empilhadeiras se encontravam. Esse dado foi confirmado em entrevistas com permissionários.
} 
sua destruição como se fossem brecar um processo de desenvolvimento tecnológico. Em pouco tempo, os carregadores do Terminal perceberam que essa ação não teria efeito frente ao processo de modernização que se iniciava.

Vejamos algumas opiniões sobre a presença das empilhadeiras, do ponto de vista de quem trabalha na administração:

É um processo lento, principalmente porque a gente precisa rever a infraestrutura. A infra-estrutura da CEAGESP é do final da década de 60. É uma estrutura ultrapassada, tanto para uso de empilhadeiras como para grandes veículos. Então, enquanto não rever essa infra-estrutura, esse processo vai ser lento, mas ele vai acontecer, não tem como frear isso. Você diminuindo os maiores ganhos aí, você diminui o tempo de carga e descarga, diminui o impacto que atinge a qualidade do produto, tudo isso não tem como frear. (Flávio Luis Godas, - Chefe da Seção de Economia e Desenvolvimento)

Vejamos outro parecer:

Você tem que paletizar, porque é uma loucura você ficar batendo caixa por caixa, se leva... você pega lá quinze minutos para descarregar um caminhão você leva duas horas; quando é embalado à granel, como vem o abacaxi, você leva seis horas para descarregar. Isso é uma loucura, produto perecível [...] O cara tem condição de vida pavorosa, aí os caras carregam um peso imenso, não tem. Isso não é ser exigente. Tem que dar um outro caminho pra isso aí. Tem de empurrar a modernização e empurrar capacitação deles junto. O que não pode é ficar um puxa pra traz... é uma questão de sobrevivência.[...] Porque os atacadistas têm medo dos carregadores, é uma relação de medo. O carregador é autônomo, é visto como autônomo e ganha como autônomo e põe na justiça contra o atacadista. Ao mesmo tempo o atacadista é obrigado a usar o carregador, por causa do sindicato. Os caras sabem que têm que melhorar, eles não têm nada de burro, o que precisa é uma decisão de modernização pra mudar. Aí têm que privilegiar carga paletizada. (Anita de Souza Dias Gutierrez, chefe do Centro de Qualidade em Horticultura)

Sobre a problemática das inovações tecnológicas que vêm transformando o mundo do trabalho, não só no setor produtivo strictu sensu, mas na própria circulação da mercadoria, encontramos uma reflexão de Marx, acerca da entrada dos teares mecânicos, na Inglaterra, no séc. XVII, vejamos:

Sob a sua forma máquina [...] o meio de trabalho torna-se imediatamente concorrente do trabalhador. O rendimento do capital está a partir de então na razão direta do número de operários a quem a máquina aniquila as condições de existência [...] desde que a manutenção do utensílio cabe à máquina, o valor de troca da força de trabalho desaparece, ao mesmo tempo que o seu valor de uso. $\mathrm{O}$ operário como moeda tirada de circulação já não tem curso. $^{231}$

${ }^{231}$ Karl Marx, O Capital (1996 [1867] ), t.2, p.112 


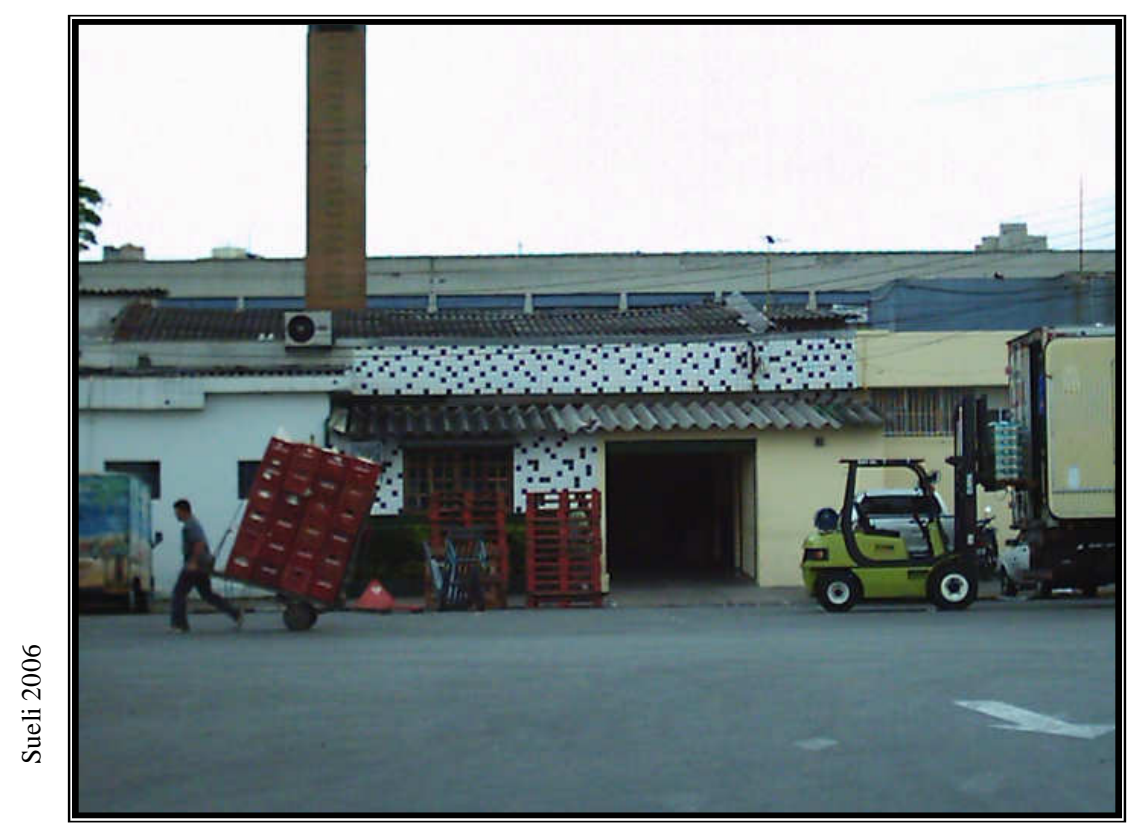

Foto 36: Empilhadeira.

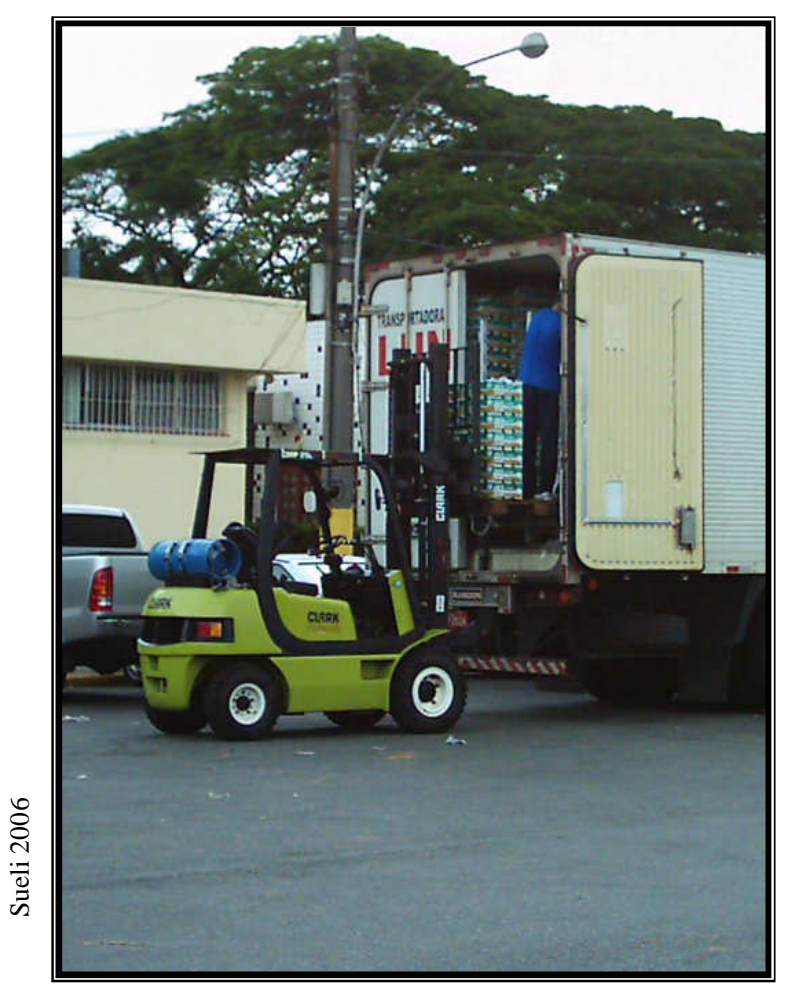

Foto 37: Empilhadeira no setor das frutas do Terminal da CEAGESP na Capital. 
Dessa maneira, o ofício do carregador vai perdendo o seu valor de troca, a medida que são introduzidas as empilhadeiras, desarticulando assim as conquistas da categoria. Enquanto isso, a direção do Sindicato percebe as novas necessidades e dificuldades que a categoria irá enfrentar e a sua preocupação corre no sentido de pensar uma possível qualificação para aqueles trabalhadores. Vejamos abaixo o projeto que se pensou no início da década:

A implantação de uma escola profissionalizante para os carregadores, preparando-os através de uma formação técnica específica, para que eles tenham uma profissão a exercer quando deixar sua função. O serviço também será estendido às famílias, que poderão freqüentar a escola... (Zé Pinheiro, novembro de 2001, Jornal Entreposto)

Não encontramos nenhum registro de carregador autônomo que se tornou o operador de empilhadeiras ${ }^{232}$. Os dados da CEAGESP indicam que mais de $12 \%$ dos carregadores são analfabetos e que $73 \%$ dos carregadores não terminaram o ensino fundamental. Em julho de 2004, iniciou-se um curso de alfabetização gratuito para os carregadores, promovido pelo Programa de Alfabetização e Inclusão, pelo Centro Integrado Empresa Escola e pela Universidade Mogi das Cruzes, curso que acontecia no galpão do Sindicato. Iniciaram aproximadamente 15 (quinze) carregadores, depois restaram apenas 4 (quatro), que foram transferidos para o projeto da Escola Nossa Turma, e desde então já não há mais o curso no espaço do galpão. Nesse quadro, residem alguns questionamentos: como inserir esse trabalhador em tempos de modernização, sendo que o tempo de aprendizagem é diferente do tempo da velocidade da ampliação do capital. Será que existe a inserção sob o capital? Que inclusão esperar nessa lógica da modernização? Que projeto de capacitação poderia inseri-los em uma modernização que emprega o menor número de pessoas? Vejamos o depoimento que relata o cenário de desemprego que se instala no Terminal nesse processo de modernização e mobilidade:

Zé:Uns já têm o serviço certo. E o outro fica, lá, esperando para ver se aparece alguma coisa. Agora, o sofrimento daquele que fica esperando. Porque tem dia que vem e outro dia não vem para trabalhar.

Sueli: Ele vem por conta?

Zé: É carregador, registrado, ele chega lá e fica esperando se o cara vem comprar e chama ele para trabalhar.[...] Carregador, não é do box. É feirante, quando vem, parado, você viu, aquele parado ele estava esperando alguém comprar uma caixa e chamar ele para carregar.

Sueli: Parados?.

\footnotetext{
${ }^{232}$ Benassi conta que seus empregados foram fazer o curso para dirigir as empilhadeiras, um era conferente e o outro era carregador, registrado.
} 
Zé: Pois é, e o que não pegou nenhum?Você vai achar um que não pegou nenhum serviçinho hoje, gastou condução, chega e não ganha nem para o almoço. E a casa do cara como é que fica?

\section{Sueli: Desistências?}

Zé: Tem. E não desiste muito porque não tem pra onde ir, porque não tem o que tem uma profissão, senão... e não tem serviço, mas tem muitos indo para roça, quando acha um serviçinho na roça e vai. (Zé)

Para Zé Cândido, 52 anos, carregador de Inhuma, no Piauí, o que mais reduz o trabalho do carregador é o desempregado, que representa aquele que tira o serviço do carregador regulamentado. Este é o elemento visível, no qual os carregadores identificam a sua precarização, levando ao descrédito na tabela de preços das carretas e, dessa forma, diminuindo os rendimentos. O nosso desafio neste contexto é ir além desse visível e ler o invisível, ir além das representações e imagens, e buscar a essência desses processos que desencadeiam a precarização do trabalho, tendo como empírico o trabalho do carregador.

Assistimos ao processo de modernização que atua nos elos que compõem a circulação da mercadoria, tanto quando vemos as redes de supermercado substituírem as feiralivres, quanto quando as empilhadeiras substituírem os carregadores. Vejamos uma passagem da obra de Milton Santos (1986) sobre a atuação da modernização na reprodução e ampliação do capital:

O processo de modernização afeta de modo diverso as estruturas antigas. Às vezes o resultado é a sua corrosão ou mesmo destruição. Em outras oportunidades, os circuitos de grandes firmas e de ramos modernos se associam, para sua própria vantagem, com heranças de fases produtivas anteriores, contribuindo para prolongar formas pretéritas, embora sob novas e diferentes relações. (SANTOS, 1986: 130)

O autor elabora essa reflexão para pensar a formação das holdings e o processo produtivo. No entanto, percebe-se que a intervenção da modernização não reordena apenas o setor produtivo strictu senso, mas também a própria circulação da mercadoria.

A flexibilidade do trabalho, que consideramos como o trabalho móvel, foi estudada por Antunes (2000). Essa dimensão da relação do trabalho surge nos anos 50 no Japão, com a implantação do toyotismo no sistema produtivo, e se amplia para o Ocidente, organizando o trabalho e reestruturação o capital. No Brasil, assim como em toda a América Latina, a flexibilização do trabalho aparece com a flexibilização da legislação trabalhista, com a perda de direitos adquiridos, a expansão dos trabalhadores sem carteira registrada e os chamados subempregos. Vejamos: 
Paralelamente a essa tendência [desemprego estrutural], há uma outra extremamente significativa, dada pela subproletarização do trabalho, presente nas formas de trabalho precário, parcial, temporário, subcontratado, "terceirizado", vinculados à "economia informal", entre tantas modalidades existentes. Como diz Alain Bihr (1991:89), essas diversas categorias de trabalhadores têm em comum a precariedade do emprego e da remuneração; a desregulamentação das condições de trabalho em relação às normas legais vigentes ou acordadas e a conseqüente regressão dos direitos sociais, bem como a ausência de proteção e expressão sindicais, configurando uma tendência à individualização estrema da relação salarial. (ANTUNES, 2000:52)

O processo de precarização do trabalho envolve, também, as atividades autônomas e regulamentadas, pois estas sofrem uma saturação com o desaguadouro de toda força de trabalho que desistiu de procurar emprego regulamentado, parafraseando Singer (2000). Os estudos de Vasapollo (2005) reforçam nossa análise sobre as transformações que o trabalho sofre sob o capital. Segundo o autor:

As novas figuras do mercado de trabalho, os novos fenômenos do emprendedorismo, cada vez mais se configuram em formas ocultas de trabalho, assalariado, subordinado, precarizado, instável, trabalho 'autonômo' de última geração, que mascara a dura realidade da redução do ciclo produtivo. $\mathrm{Na}$ verdade, trata-se de uma nova marginalização social e não de um novo empreendedor. (VASAPOLLO,2005:10)

A precarização do trabalho resulta em um menor poder de negociação dos sindicatos frente ao crescimento acelerado do desemprego. Esse processo é explicitado na CEAGESP quando o acordo da tabela estabelecido entre o Sindicato e a Companhia deixa de ser respeitado pelos próprios carregadores, pois a expansão de ofertas de força de trabalho acirra a disputa por um serviço e a grande concorrência entre eles.

Pochman (2000) mostra como os anos 90, para o Brasil, foi um período de baixos indicadores econômicos se comparados com décadas anteriores, e foi acelerado pelas políticas neoliberais de privatizações, como constatamos em nossas pesquisas sobre o processo de sucateamento da CEAGESP, com o propósito de privatizá-la. Como fruto dessa política liberal, de acordo com aquele autor, foram fechados 3,2 milhões de postos de trabalho regulamentados, somente naquela década. Esse processo foi sentido nos corredores do Terminal de Abastecimento, pois a procura por uma forma de trabalho foi ampliada pelos homens mobilizados, e ficou expressa no conflito entre o carregador clandestino e o regulamentado. Além dos postos de trabalho fechados, fora dos muros do Terminal, ali dentro eram introduzidas novas técnicas, como a paletização e as empilhadeiras. Ocorreu também a diminuição das feiras livres que resultam na dispensa de uma parte dessa força de trabalho, principalmente, do carregador. Desse modo, percebemos na pesquisa o processo de 
precarização do trabalho, assim como homens idosos ainda trabalhando ou pessoas com maior nível de escolaridade assumindo a função de carregador, além de um menor poder de barganha do Sindicato frente às transformações que a reestruturação do capital impõe.

\subsubsection{Travessias Ocupacionais}

A maior parte dos carregadores que estudamos iniciou a sua trajetória de trabalho na roça, na sua área de origem. Alguns tiveram outras experiências migratórias antes de chegar em São Paulo. Nas entrevistas aparecem migrações pelo Rio de janeiro, Londrina, Santos ou partes do Nordeste. Um outro grupo migrou direto para São Paulo.

O percurso ocupacional de uma parte dos carregadores mostra outras experiências de trabalho em São Paulo, antes de sua inserção no Terminal. Alguns, antes de serem carregadores autônomos na Companhia, eram assalariados.Trabalhavam principalmente, na construção civil, e, depois, nos mais diversos serviços que as empresas contratavam, serviços insalubres no setor de química ou serviços pesados, tanto quanto o serviço de carregador. Eles avaliam que a passagem de assalariado para autônomo foi positiva, pois essa mobilidade de atividade possibilitou melhores condições de trabalho. Entre os entrevistados, encontramos no setor do pescado alguns carregadores que já tinham sido trabalhadores por conta própria; tinham sido comerciantes, compravam mercadorias no Entreposto. Quando as suas atividades comerciais fracassaram, eles passaram a trabalhar como carregadores. Outro grupo teve como única experiência de trabalho em São Paulo a função de carregador no Terminal. Os mais jovens tiveram como única e primeira atividade o ofício de carregador. Ocorre, também, uma mobilidade do trabalho no espaço interno da Companhia, em que uma parcela dos carregadores autônomos já foi empregada nos boxes, ou então, auxiliar ou subordinada aos seus conterrâneos que eram cadastrados.

Encontramos nas trajetórias dos piauienses a ocorrência de carregadores que passaram a seguir a carreira artística, como o ex-carregador da CEAGESP e artista plástico Apolinário Hipólito Ferreira Neto, conhecido como Narim. Nasceu no Piauí, descendente de indígena, filho de lavrador e dona de casa, chegou em São Paulo aos 14 anos de idade, trabalhou como garçom, funileiro, soldador e, em 1979, ingressou na CEAGESP, como carregador. Atualmente, ele já tem mais de mil quadros, que abordam temas sociais, como a reforma agrária, a prostituição infantil, o aborto. Já expôs em vários países da Europa, Japão e 
participou da Bienal de Arte de São Paulo. Atualmente, leciona na escola de arte de Osasco e comanda uma ONG. Mantém, ainda relações com o Terminal, onde circula algumas vezes.

Outro carregador que traz evidencias da cultura nordestina é o repentista e poeta José Daniel. Ele chegou do Piauí em 1970 e desde 1975 exerce a profissão de carregador. É também diretor do Sindcar. Filho de um lavrador que também produzia repentes, seu estilo regionalista produz poesias sobre o cotidiano do Entreposto. (Veja o cordel O Permissionário [1999] em anexo $n^{o}$ 26). O piauiense Bacana, empregado no box e ex-atacadista, retornou para o Piauí para montar uma banda de música, no entanto, não tendo conseguido se estabelecer, retornou ao CEAGESP. Essas trajetórias trazem a presença nordestina nos poros do Terminal. ${ }^{233}$

\subsubsection{A mobilidade social do trabalho}

A mobilidade que encontramos no Terminal não foi apenas a do deslocamento espacial do nordestino para São Paulo. Foi, também, de posição social, da condição de carregador para a de permissionário. No trabalho de campo, constatamos, nos boxes, nordestinos presentes no controle de parte das atividades comerciais, principalmente, nos setores dos legumes, verduras e frutas. Vejamos os depoimentos de antigos permissionários: “[...] os nordestinos, que eram funcionários, hoje são donos de boxes. Antigamente era só japoneses e portugueses." (Permissionário descendente de Japoneses).

Outro depoimento: "Na venda das flores estão principalmente japoneses, portugueses e holandeses, mas os legumes estão entrando os nordestinos”. (Luciana, permissionária da Feira das Flores).

Nos setor da batata, cebola e alho, encontramos Marcos Tavares e seu irmão; filhos de sergipanos, iniciaram o negócio desde os primeiros tempos da Companhia, comercializando coco seco, batata, alho. Possuem ainda uma das Casas do Norte, alugando vários boxes para atuar com essa diversidade de produtos.

Os carregadores autônomos que se tornaram donos de box estão situados principalmente no setor das frutas e legumes. No setor do pescado não obtivemos nenhuma informação de algum carregador que tenha se tornado permissionário.

\footnotetext{
${ }^{233}$ Fonte: Fevereiro de 2000 no jornal Elo, Gente Nossa.
} 
Alguns deles têm o seu estabelecimento no pavilhão MFE-B, mas a maioria está concentrada no pavilhão MFE-C.

Sobre esse tema, vejamos o que diz o permissionário, ex-diretor de sua Associação: “Alguns se deram bem, e vai indo bem, outros estão saindo, não conseguiram se manter.” (Mário Benassi)

Encontramos piauienses permissionários numa faixa etária cuja média não atinge os 50 anos. Vejamos o relato de um deles sobre a grande presença dos piauienses no controle dos boxes no pavilhão das frutas ${ }^{234}$ e legumes: “Um box hoje, vale $R \$ 80$ mil, mas naquela época valia duas motos. Fase boa para comprar box, em 90. Todo mundo chega junto e compra, você queria, usava aqui dois meses e já era seu." (Jonas)

O jovem permissionário recorda que era muito fácil conseguir crédito. Ocorreram situações em que alguns piauienses aproveitaram a oportunidade e deram o calote em produtores e em clientes e foram embora para a área de origem: “[...] crédito para ganhar 200 mil [...] Lugar fácil de se dar cano no outro”. Depois disso, quem ficou demorou para reconquistar a confiança; mas hoje, afirma o jovem piauiense, “[...], começaram a vir pessoas tudo direita".

Francisco de Paula, piauiense de Lagoa do Sítio, migrou em cima de um caminhão, foi carregador, e hoje é atacadista no setor da fruta e legumes e contrata seus conterrâneos para trabalhar. De Paula ainda é cadastrado como carregador, e atua e contribui com o Sindcar. Vejamos um fragmento dessa entrevista:

[...] quando eu tinha doze ou treze anos de idade, eu já tinha vontade de vir conhecer o CEASA, de saber como era. Com quinze anos o pessoal deixava a mercadoria lá em casa, aqueles sacos de feijão, arroz, de goma. Eu com quinze, eu já colocava, pegando bujão ficava treinando que era vontade de vir para CEASA [...] Eles falavam que não era fácil, quase ninguém queria dar a oportunidade pra vir até que teve um primo meu, lá, eu conversei com ele, ele falou que dava pra ficar na casa dele.(De Paula)

Esse permissionário veio com 16 anos. Ele tinha estudado, na área de origem, até a sétima série, em 1995. Veio em cima do caminhão de seu tio, pagou pela viagem, que durava na época seis dias, o valor de cinqüenta reais, aproximadamente. Com ele vieram mais seis pessoas. Vejamos a continuidade de seu relato:

Saímos de casa, em cima de um caminhão com uma mala, aí até o pessoal brinca - 'a mala é o saco e o cadeado é o nó'. Agente veio, veio de Valença do Piauí, de Valença pequei um ônibus e vim até Picos e em Picos vim em

\footnotetext{
234 A estimativa de Jonas, permissionário piauiense, é de que a maioria dos boxes do pavilhão do MFE-C controlada por piauieses.
} 
cima do caminhão com o meu tio. Esse caminhão trazia bastante coisa que vinha pro CEASA, encomenda do pessoal; Goma, farinha, essas coisas que o pessoal traz. Esse caminhão leva mudança daqui pra, lá.

Seu relato continua no sentido de esclarecer como foi sua trajetória até chegar a se tornar atacadista; naquela idade ele não tinha autorização para iniciar-se como carregador cadastrado, então, trabalhou mais de um ano como 'ajudante' do seu primo, até ser convidado a trabalhar com o padrinho de seu primo, Bacana, no pavilhão do setor das frutas, MFE-C. Foram três anos em que ele fez amizades com os compradores e fornecedores, o que o preparou para trabalhar no ramo de frutas. Até que conseguiu o cadastramento para trabalhar como carregador. Nesse tempo, o seu antigo patrão, $o$ Bacana, desistiu da atividade comercial e retornou para o Piauí para investir na carreira musical. Depois de um ano, comprou o seu primeiro box ${ }^{235}$, e iniciando os seus negócios. Atualmente, está com 27 anos e cursa Administração, possui apartamento, duas casas alugadas, quatro boxes no setor de frutas e dois no setor dos legumes, e, além disso, construiu um posto de gasolina na sua cidade de origem. Enquanto isso, seu ex-patrão, o Bacana, que perdeu o que havia amealhado, foi convidado para vir novamente para São Paulo para trabalhar com ele: "Convidei ele pra vir comigo e tá refazendo a vida, tô ajudando, tá terminando de me pagar”.

Assim, encontramos nos poros do Entreposto duas histórias de grande mobilidade, entre as idas e vindas. Francisco de Paula teve uma rápida ascensão social, de acumulação de capital e pecúlio, originado do trabalho de carregador e de empregado, tornando-se, depois, atacadista.

Ao perguntarmos a carregadores sobre os seus planos e sonhos, poucos revelaram a vontade de ter seu próprio negócio. Parte deles cita exemplos de colegas que se embrenharam como atacadistas e não conseguiram se manter na atividade. Normalmente esse grupo de pessoas está acima dos quarenta anos de idade e não pensa em sair do ofício de carregador, e nem em se tornar assalariado. Vejamos uma das entrevistas: "Muitos viraram donos, outros caíram. Uns têm roça, outros não têm e quebram a cara. Se entra quebra a cara, pega cheque sem fundo [...]" (Zé Candido).

Jonas, já referido, piauiense da área rural de Valença, ex-carrregador e atualmente atacadista das frutas, veio para São Paulo com 17 anos e lembra: "Aí você vê aquele monte de moto, hoje em dia as coisas melhorou, mas antes, quem tinha era artista demais. Ah! Muito moto demais, pra, lá”. O efeito do fascínio dos óculos escuros, discutidos por Martins (1988), aparece hoje nas motocicletas adquiridas com os rendimentos dos migrantes, “[...] uma

\footnotetext{
${ }^{235} \mathrm{Na}$ época pagou o valor de onze mil reais.
} 
máscara que define as pessoas no grande mundo das mercadorias [...]”. Esse piauiense trabalhou sete meses de servente de pedreiro para pagar as despesas do cadastramento. Começou a trabalhar como carregador autônomo em 1995 quatro anos depois já estava comprando o seu box. Quando pergunto sobre os problemas que enfrenta hoje, ele responde:

O que mais incomoda, mesmo, é sim, as pessoas, mesmo. A pessoa que te vê você saiu dali, você fazia isso e de repente você é isso. A pessoa chega já chega: "Você é isso, você aquilo..".fica olhando o que você tem, o que você faz, aí incomoda o outro, às vezes vai no cara errado, aquele cara lá é isso é aquilo. [...] Prejudica nem só eu, todas as pessoas estão submetidos a ser roubado.[...] Estão matando gente direto lá na saída. (Jonas)

Essa mobilidade do trabalho, levando alguns desses piauienses à ascensão social e mudança de padrão de vida, visto que subiram na pirâmide social e ganharam entre os conterrâneos uma maior visibilidade, traz para eles problemas que antes não tinham. Em particular, traz o medo de serem roubados, ou até mortos. A entrevista com Jonas foi feita dias após o assassinato de um piauiense que comercializava caixas reutilizáveis, atividade que trazia, também, um novo padrão econômico de vida.

\subsection{O carregador da CEAGESP sob os circuitos da economia urbana}

Identificamos em nossa pesquisa os dois circuitos da economia presentes no processo em que se encontra incluso o carregador autônomo da CEAGESP. Esses dois circuitos da economia urbana se estendem em muitos elos e formam correntes que se entrelaçam sob o capital. Vamos tentar desembaraçar isto que à primeira impressão parece-nos um grande novelo; essa configuração no entanto obedece a uma lógica nessa estrutura entremeada, e reproduz diferentes formas de trabalho que sofrem metamorfoses acompanhando as necessidades da ampliação do capital. Entre as atividades do Terminal da CEAGESP, selecionamos a categoria do atacadista e do carregador, para visualizar os elos da circulação da economia.

Vejamos a análise de Santos (2004) sobre os atacadistas e o seu elo da circulação nos circuitos da economia urbana:

O atacadista está no topo de uma cadeia decrescente de intermediários, que chega freqüentemente, ao nível do "feirante" ou do simples vendedor ambulante.[...] Elemento integrante do circuito superior, o atacadista é também o cume do circuito inferior. (SANTOS, 2004 [1979]:41) 
Já o carregador autônomo tem uma atividade de pequena dimensão em que precisa de poucos recursos para se inserir, isto é, o suficiente para pagar as despesas com o cadastramento, o carrinho, o uniforme e a manutenção anual do seu cadastramento. Os seus ganhos dependem do dispêndio de sua força de trabalho. Por essas qualidades a atividade do carregador está inclusa no circuito inferior.

Esse circuito apresenta uma "elasticidade", ou melhor, diria uma plasticidade "para gerar empregos", característica que abrange diversas formas de trabalho.

Tanto aqueles que estão em situação de irregularidade frente ao Estado, denominados de clandestinos, e os regulamentados formam elos entrelaçados, que compõem um dos elos da corrente da circulação da mercadoria. Tanto um como outro executam formas de trabalho que não necessitam especialização ou grau de escolaridade.

No entanto, com o processo de modernização do abastecimento alimentar que, nas últimas décadas, reduziu o papel das feiras livres e dos feirantes e expandiu, antes de mais nada, a redes de supermercados e hipermercados, vem levando, de uma lado, a que as empresas, donas dessas redes dependam cada vez menos de aquisições em terminais de abastecimento; de outro lado, leva a pressões no sentido de modernização da logística de deslocamento e armazenagem de produtos nesses terminais, como por exemplo, o aumento da utilização de empilhadeiras. O avanço deste último processo só não foi maior, ainda, entre outros fatores, pela própria inadequação das instalações do Terminal da Vila Leopoldina e de suas condições de circulação interna, projetadas no final dos anos 1950.

Com isso, a quantidade de trabalho para os carregadores tende a diminuir, o que aconteceu particularmente a partir dos anos de 1990, mobilizando esses trabalhadores para outras atividades.

O mesmo carregador pode seguir durante a sua trajetória de trabalho diferentes formas e características, pois segue a lógica da mobilidade do trabalho. Mas mesmo enquanto clandestino, em irregularidade diante do controle do Estado, está completamente incluso no processo de produção ampliada do capital. Assim, não podemos dizer que esse carregador está a margem ou excluído desse modelo de civilização. Vejamos como Martins (1998) discute o conceito de exclusão:

Na sociedade capitalista, a rigor não pode haver exclusão; não pode existir sociedade capitalista baseada na exclusão. Toda dinâmica dessa sociedade se baseia em processos de exclusão para incluir [...] Há duas portas para se entrar nessa sociedade. Uma é a porta mais geral da transformação de todos em produtores e vendedores de mercadorias. Tudo tende a ser reduzido a mercadoria. Essa redução de tudo a produtores e consumidores de mercadoria significa que todos, para se integrarem na sociedade capitalista, 
devem ser transformados em trabalhadores ou, então, compradores de força de trabalho. (MARTINS, 1998:19-20)

No momento em que esses carregadores conseguem o cadastramento, passam a ter uma condição de regulamentados, são considerados legalmente como autônomos. Eles vendem as suas forças de trabalho oferecendo o serviço de transporte da mercadoria. Uma parte dessa categoria, com o seu pecúlio, pode ser novamente mobilizada, tornando-se atacadista de gêneros alimentícios ou então investindo em um pequeno negócio, o que ocorre com freqüência, na sua área de origem. Existem algumas mobilidades diferenciadas, como a saída e posterior retorno à atividade de carregadores. A grande maioria desses trabalhadores permanece naquela atividade até a aposentadoria ou morte. Segue o autor:

Esse circuito é o verdadeiro fornecedor de ocupação para a população pobre da cidade e os migrantes sem qualificação. Tudo isso está ligado às condições tecnológicas e financeiras das atividades desse setor e a (sic) suas relações com o conjunto da economia urbana (SANTOS, 2004 [1979]:45).

O trabalho de carregador é caracterizado por sua intensidade, pois usa, além da força do trabalhador, tecnologia mais simples, apenas o carrinho puxado à mão. Desse modo, possibilita a absorção de um número considerável de pessoas na ocupação. O contrato entre o comprador do serviço e o trabalhador acaba sendo um acordo pessoal e oral, baseado no trabalho autônomo. 


\section{PRESENÇA E REDE SOCIAL DE PIAUIENSES NO TERMINAL DA CEAGESP}

O que mais nos chamou a atenção nesse universo de trabalhadores é o fato de que a maior parte dos carregadores tem a sua origem no Estado do Piauí. ${ }^{236}$ Essa grande rede social de piauienses foi o suporte de entrada de muitos dos migrantes que trabalham na CEAGESP ${ }^{237}$.

Os carregadores piauienses têm presença significativa em quase em todos os setores do Terminal, exceto no setor do Pescado, no qual estão, proporcionalmente, em menor número. Neste setor, há o predomínio de paraibanos, formando outra rede de relações sociais, muito menor do que a de piauienses, conforme identificado nas entrevistas e nos dados cadastrais. $\mathrm{O}$ que pode explicar a quase ausência de piauienses nesse setor pode ser a menor possibilidade de trabalho que o pescado oferece, além dos menores rendimentos. Ao entrarmos nas filigranas dessa rede social, constatamos que os piauienses do município de Pio IX se inseriram, principalmente, no setor da Batata. Atualmente, eles se deslocaram para outros setores, pois o setor de Batata possui uma circulação de mercadorias menor que a de outros setores, como o das Frutas e o dos Legumes.

O mapa da área de origem dos carregadores indica que a maior parcela deles é oriunda da mesorregião do Sudeste e parte do Centro Norte do estado do Piauí ${ }^{238}$, havendo um espraiamento a partir do limite com o Ceará. Identificarmos que essa rede de piauienses estava vinculada a um grupo menor de cearenses. Deste modo, essa rede social não segue os limites das unidades federativas e sim constrói seus próprios limites. Ver a seguir, os gráficos 5 e 6 ( contruídos a partir das tabelas de Origem do Carregadores elaboradas a partir dos dados do cadastramento dos carregadores, veja os anexos 27, 28 e 29) :

\footnotetext{
${ }^{236}$ O Estado do Piauí apresenta um dos piores índices de Exclusão Social. Enquanto a média nacional é de 0,527, o Piauí apresenta um índice de 0,213, conforme os dados de 2000. O Índice de Desenvolvimento Humano do Piauí (2000) é de 0,673 (CEPRO, 2003)

${ }^{237}$ MIGUEZ (1995) e RAMELLA (1995) trazem um arcabouço teórico para o debate sobre redes sociais, assim como os elementos apresentados na dissertação de GOMES (2002).

${ }^{238}$ A subdivisão do estado do Piauí conforme a publicação da Fundação CEPRO (2003)
} 


\section{Gráfico 6}

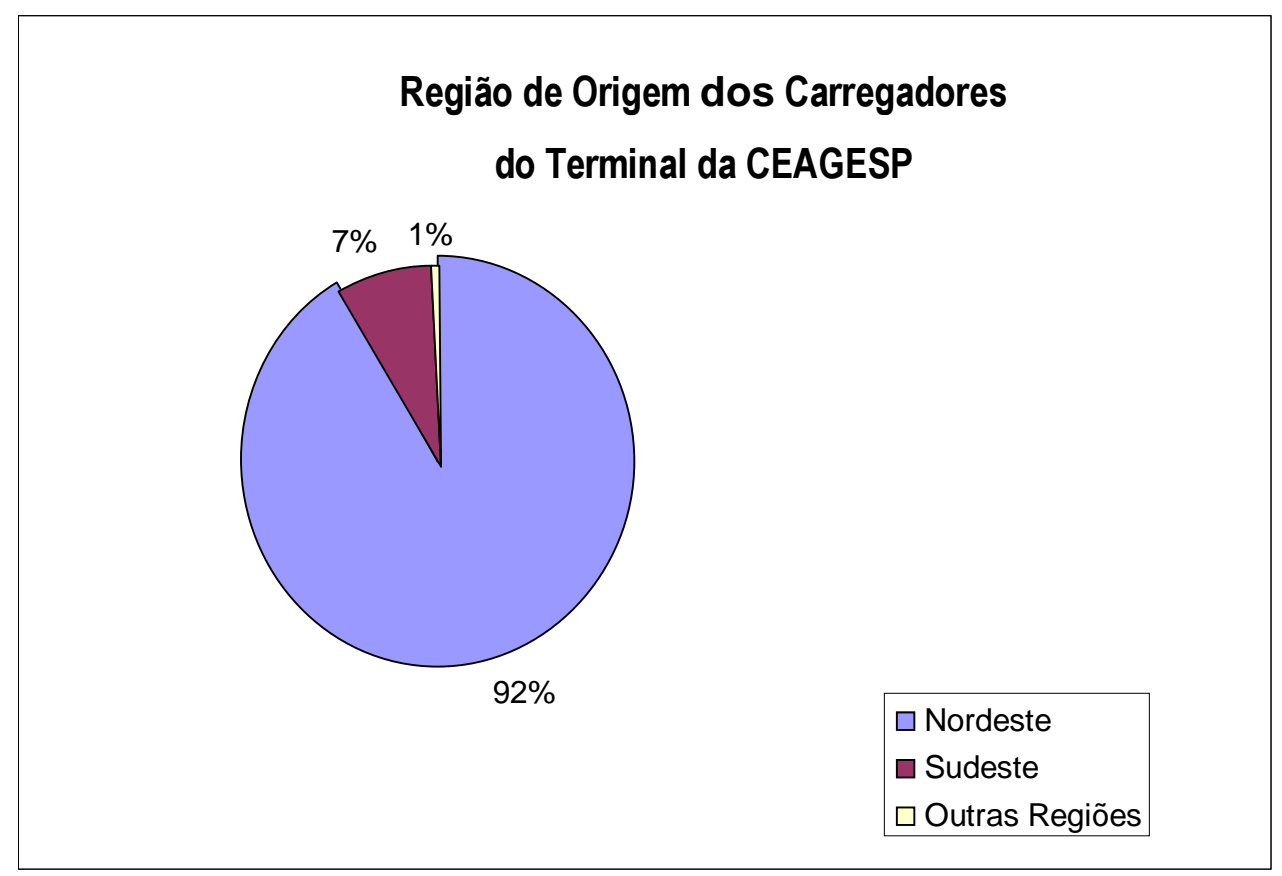

Fonte: CEAGESP e Org: Sueli de Castro Gomes

\section{Gráfico 7}

Estado de 0 rigem dos Carregadores do Terminal da CEAGESP

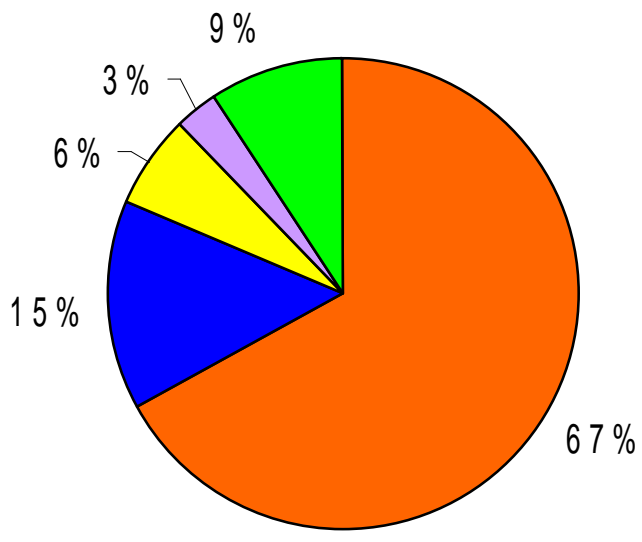

$\square$ Pia uí

$\square$ C e a rá

$\square$ São P a ulo

$\square$ Pernam buco

$\square$ Outros Estados

Fonte: CEAGESP e Org: Sueli de Castro Gomes 


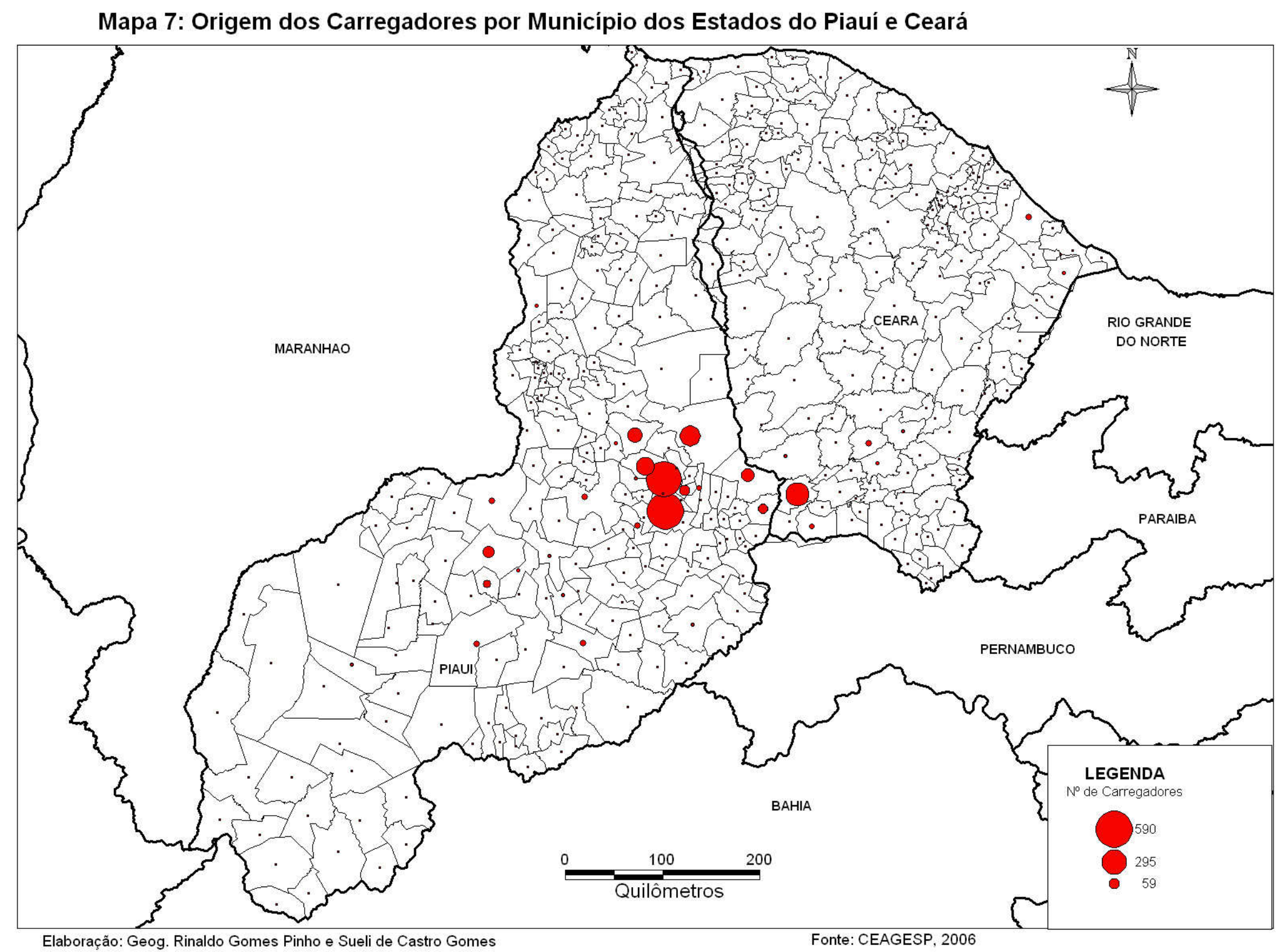




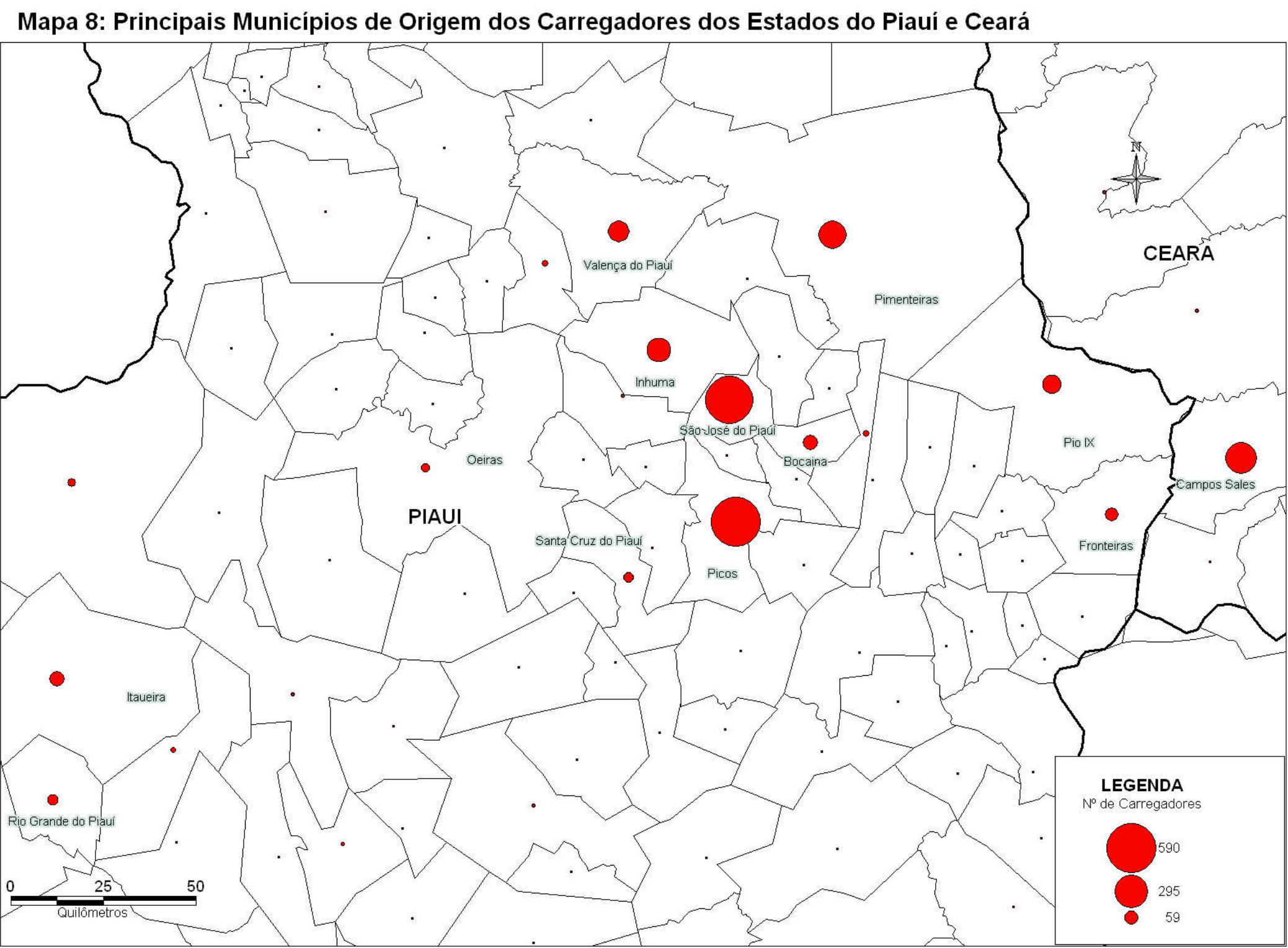

Elaboração: Geog. Rinaldo Gomes Pinho e Sueli de Castro Gomes

Fonte: CEAGESP, 2006 
No período de transferência do Terminal, na segunda metade dos anos 60, o grupo de migrantes nordestinos que se inseriu na atividade tinha origens mais diversificadas. Havia um pequeno predomínio de cearenses, dos quais alguns ainda estão na ativa, conforme constatamos. Acredita-se que a origem dessa rede social se deva aos cearenses de Campos Sales, município no semi-árido, próximo do limite com o Estado do Piauí. Posteriormente, vieram com mais intensidade os carregadores de São José do Piauí e Pio IX, municípios limítrofes do Piauí e Ceará. De tal modo que a rede de informações atingiu outros municípios, intensificando-se o fluxo de migrantes em direção ao Terminal da CEAGESP. O espraiamento das informações, explicitando a territorialidade dos carregadores, ganha visibilidade com a representação cartográfica da área de origem desses migrantes, oriundos da região do semiárido, o que pode ser visto no mapa $\mathrm{n}^{\circ} 8$.

Além dos piauienses, entrevistamos carregadores oriundos de outros estados e até mesmo paulistanos, que justificaram sua entrada na atividade através dessa rede social, por serem casados, terem outro grau de parentesco, ou por conhecerem pessoas oriundas do Piauí que foram mobilizados para esse mercado de trabalho. Há também, aqueles que, em menor número, entraram nessa atividade antes da formação dessa grande rede, ou conseguiram esse trabalho por outro contato social fora da rede predominante.

As informações sobre as possibilidades de trabalho em São Paulo eram trazidas por aqueles que já estavam inseridos no Terminal; esses serviam de referência para aqueles que desejavam migrar. Aqueles que retornavam eram denominados de "Paulistas" em sua área de origem. Vejamos o relato: "Eu que queria mesmo que conhecê o CEASA. Todo dia agente via, chegava daqui os paulistas; chegou os paulista, os paulistas era tudo do CEASA!!!"

A referência dos piauienses não era a cidade de São Paulo, mas sim a sede da CEAGESP. "Você chega em São José de Piauí você não vê uma pessoa falá que vai para São Paulo, é só CEASA."

Alguns migrantes da década de 70 recordam que, da antiga Rodoviária, próxima à Estação da Luz, eles vieram direto para o "Ceasa"; tomavam o trem na Luz ou pegavam um táxi, e chegavam sozinhos, como gostam de reforçar. Apontam as suas primeiras dificuldades: lidar com a documentação exigida para o cadastramento, bem como com as exigências para alugar uma casa. O baixo nível de instrução, a inexperiência e a falta de um fiador eram barreiras para esse migrante que vinha do campo em um tempo em que as redes sociais não estavam consolidadas.

Vejamos as lembranças do carregador piauiense da cidade de Inhuma, de quando emigraram os primeiros de seu município para a CEAGESP: 
Ceasa, já tem desde 86, que vêm parente aqui. Primeiro veio primo meu, chamado Jacó, baixinho [...]. Então tinha José, depois veio meu Tio Zé Alfredo, irmão de minha mãe. Aí veio Jacó primo da gente, aí veio meu irmão, ......, veio Laura, veio...., veio Moisés. Jacó, que é irmão meu. Aí veio [...] depois eu... (Jessé)

A presença nordestina no Entreposto aparece de diferentes formas na paisagem. Uma delas é através da instalação de duas Casas do Norte (Veja fotos no 38 e no 39). ${ }^{239}$ Elas comercializam carne seca, rapadura, farinha, cachaça, polvilho, peixe seco, queijo coalho, artesanato e todo tipo de ingredientes da culinária nordestina. No espaço interno do galpão dos carregadores também podemos encontrar todos os pertences da cozinha piauiense - desde o doce de buriti, o cajuzinho, a rapadura, até o feijão de corda, a farinha, a carne seca. Os produtos são oriundos do Estado do Piauí. Esse comércio é o registro do vaivém Piauí - São Paulo que existe no Terminal do Entreposto.

${ }^{239}$ Elas estão no pavilhão da Batata, pertencem a um atacadista, filho de sergipanos, cujos pais iniciaram o negócio nos primórdios da Companhia. Também comercializam coco e ovos, alocando outros Box. A atividade abre se $2^{\mathrm{a}}$ a $6^{\mathrm{a}}$, 8:00. às 19:30 e de sábado das 8:00 às 16:00. 


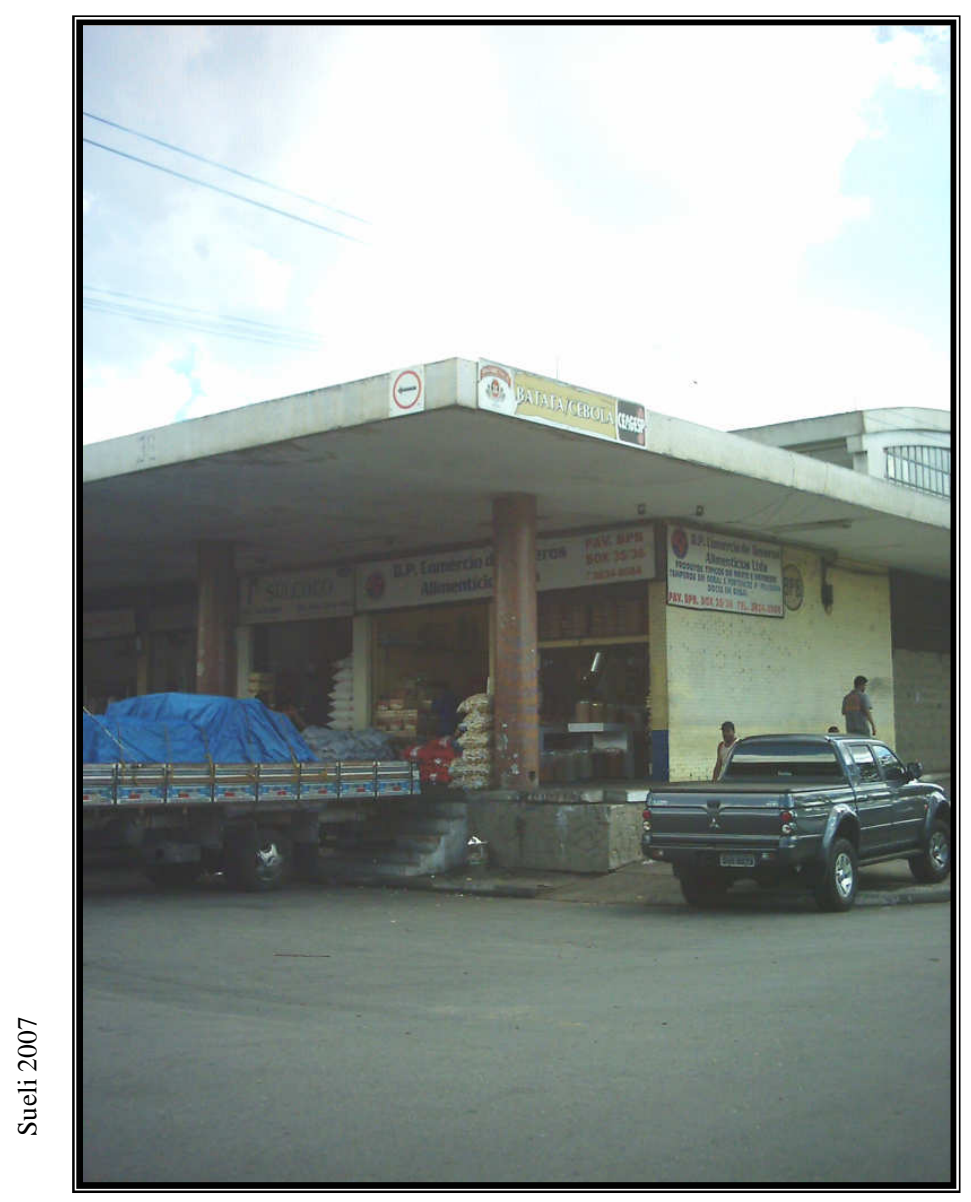

Foto: 38: Casa do Norte instalada em box no setor da Batata, Cebola e Alho

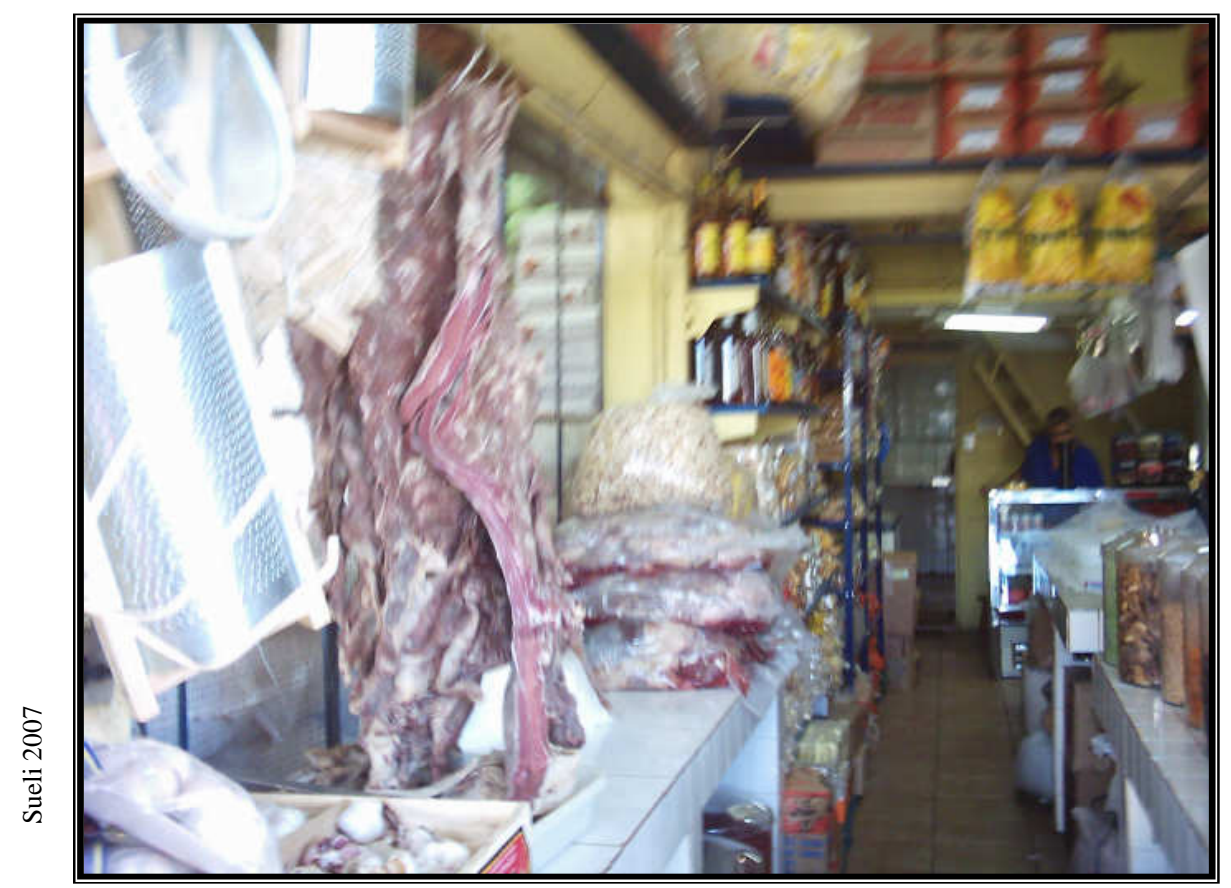

Foto 39: A casa do Norte no Terminal da CEAGESP vende no varejo os produtos voltados para a culinária nordestina. Essa atividade é um indicador da grande presença de nordestinos no Entreposto. 
Sempre que se aborda a preocupação em investigar as redes sociais, se remete aos estudos que refutavam as análises estruturais e buscavam o particular, esquecendo-se do todo. Encontra-se em duas correntes de investigação, como a da antropologia social britânica dos anos 50 e 60 (network analysis) ou da norte americana dos anos 70 e 80 (strutural analysis), uma vasta literatura, que acaba dando status científico ao conceito de rede social ${ }^{240}$. Assim também a micro-história.

A concepção de rede social que buscamos nesse estudo só ganha significado se entendermos esta como parte constitutiva da totalidade da mobilidade do trabalho estudado por Gaudemar. Estudar a rede social de piauienses dentro da totalidade que os cerca possibilita um diálogo com outras disciplinas e, portanto, não restringe o estudo ao seu isolamento científico.

Esse instrumental conceitual só tem relevância quando estudamos a relação entre sociedade e economia, ou melhor, a rede social em relação ao mercado e a sociedade produtora de mercadoria.

As relações de parentesco, familiares, de amizade e conterraneidade são construções sociais e históricas, que possuem vínculos imbuídos de contradições. Estas por sua vez, engendram "forças sociais vivas ou pontes" ${ }^{\text {"241 }}$, um dos aportes que viabilizam a mobilidade.

O migrante utiliza-se dos chamados recursos relacionais para se inserir no mercado de trabalho $^{242}$. O uso desse expediente que a relação social propicia deve passar por um acervo de informações, necessárias para que esses migrantes consigam obter uma nova forma de trabalho. Essas informações vão desde a trajetória, suporte no alojamento, acolhimento, indicações de datas e horários, documentação necessária, endereços, formas de execução da tarefa, até dicas de rendimento; enfim, a diversa gama de informações que o migrante recebe do conterrâneo o instrumentaliza para a sua mobilização. Os vínculos comunitários ganham valor estratégico na reprodução da força de trabalho. Em nossa pesquisa percebemos como a coesão dos piauienses em primeira ordem possibilitava a reserva de mercado de trabalho para o grupo; entretanto, a força da modernização estilhaça o nexo dessa conterrâneidade, pois a redução da quantidade de trabalho para o carregador no Terminal estimula maior disputa e competitividade entre esses trabalhadores.

Esses recursos relacionais estão fundados na procedência comum desses migrantes, que em momento posterior pode ampliar-se para outras relações que não as de

\footnotetext{
${ }^{240}$ RAMELLA,(1995:12-13)

${ }^{241}$ PÓVOA-NETO (1997:22)

${ }^{242}$ RAMELLA (1995)
} 
conterrâneidade, mas também de vizinhança ou casamento, como observamos entre alguns carregadores, a partir de seus depoimentos.

Ramella (1995) convida-nos, a partir da leitura de Polanyi, a nos debruçarmos sobre a questão do mercado de trabalho relacionado à migração. Para o autor, há uma ambigüidade na teoria que afirma que as relações pessoais são anuladas diante da industrialização. “ apesar de ser considerados como uma sorte de resíduos do passado - correlativos a pequenos grupos sociais de emigrantes provenientes de zonas rurais atrasadas - se tende sugerir que se trata de fenômenos destinados a ser superados com a plena inserção na moderna sociedade urbana e industrial" (p.18). O autor insiste na importância dos vínculos sociais na busca de trabalho. São mecanismos informais de recrutamento Essa idéia da superação dos elos da rede social universaliza o processo de recrutamento, porque tem como pressuposto uma racionalização perfeita do moderno mercado de trabalho.

No debate aqui proposto, lembramos o crescimento do circuito inferior, na reprodução e ampliação do capital, fugindo dessa universalização do moderno mercado de trabalho. Portanto, os mecanismos informais de recrutamento estão presentes no processo de modernização, pois eles são parte do processo de inclusão, e seguem a lógica do capital. Desse modo, os laços pessoais são indicadores para a análise macro do mercado, e importantes, em tempos de redução do trabalho regulamentado e de sua metamorfose. Vejamos mais sobre a relevância do estudo das redes sociais para identificar a inserção do migrante no Terminal ou em outra forma de trabalho. Diz ainda o mesmo autor:

Son las redes de relaciones de las que forman parte, y que ellos construyen, las que estructuran las oportunidades. Es en este sentido que dichas oportunidades están socialmente determinadas; no dependen de las características personales, de los atributos, sino de las relaciones entre los actores. (RAMELLA, 1995:21).

As redes sociais possibilitam visualizar como se abrem e se fecham as oportunidades para uns e para outros. Foi possível identificar esse processo entre os carregadores cadastrados no Terminal de Abastecimento, local onde o recrutamento é fruto de um acordo entre o Sindicato e a Companhia. Esse recrutamento baseado nas relações pessoais permite o crescimento da rede de piauienses e configuram a sua territorialidade.

A relação da rede social com o espaço é identificada em alguns estudos, como o de Baptista (1998), que estudou a presença de nordestinos na favela Jardim Colombo, sudoeste do Município de São Paulo. Ela vê a rede social no aspecto das relações simbólicas de afeto ao parentesco, solidariedade e violência, identificando esse apoio no processo de assentamento, engajamento e apropriação do espaço urbano. Esses migrantes, que possuem 
identidade comum, se apóiam no passado (área de origem), no presente (o convívio) e no futuro (seus sonhos), ocupam os mesmos espaços e se socializam nesse espaço vivido e percebido. Póvoa-Neto (1997) identifica nas redes forças sociais vivas, que estabelecem "pontes" entre lugares, permitindo a circulação de informações e pessoas e usando a mobilidade geográfica como estratagema para sobreviverem.

Enquanto Ramella (1995) mostra modelos de difusão e reconhece a importância da base física geográfica para a rede social, na qual a aproximação dos indivíduos influencia na força desses vínculos, Miguez (1995) se opõem a essa concepção e refuta a idéia da proximidade espacial na difusão da informação, pois considera apenas o indivíduo no foco de sua análise. Em nossa pesquisa empírica pudemos mapear a rede social e refletir sobre o seu comportamento na metamorfose do trabalho, identificando a territorialidade dessa rede de piauienses nos interstícios da Central de Abastecimento.

\subsection{As redes sociais e o território de trabalho e moradia}

Um carregador paraibano relata com clareza a sua inserção na CEAGESP, em momentos diferentes: o primeiro cadastramento ocorreu em 1982, diretamente na Companhia; depois, ele retornou para a área de origem, em 1992, e aí permaneceu por sete anos. Depois, migra novamente, para São Paulo, e fez o seu segundo cadastro, já intermediado pelo SINDCAR, e permanece até hoje trabalhando como carregador no Terminal. Vejamos:

Um cunhado meu trouxe e disse - "Oh! O Ceasa é isso aqui, você se vira". Ele trabalha numa firma [empregado de um permissionário do pescado], mas ele não apresentou na firma, nem nada, não. Aí fiquei aí, que nem mosca tonta, né, eu falei - Daqui uma semana mais ou menos, eu vou arrumar conhecimento, aí arrumo serviço, se daqui há uns oito dias eu não arrumar, eu vou procurar numa firma. Aí, meu irmão trabalhava, fazendo uns fregueses dai do Interior, me chamou. Os caras gostaram do meu serviço, aí eu fiquei fazendo toda semana, uma vez, duas vez, por semana [...] Eu tava clandestino, né. Fiquei pouco tempo. O pessoal sempre dava em cima de mim. Aí eu vim aqui e consegui tirar documento, aí tirei documento, trabalhei um tempão. Aí fui lá pro Nordeste, fiquei sete anos sem vir. Depois quando eu vim, já tava cancelado, tornei a tirar de novo, foi dessa viagem. (Antonio)

O depoente nega que o conterrâneo o tenha apresentado em um box ou similar e se coloca em uma situação de extrema autonomia para conseguir uma oportunidade de trabalho. Mas, logo em seguida, surge durante a entrevista a figura de um irmão que estabelece contatos para sua inserção, mesmo que de forma clandestina. Em mais de uma entrevista aparece essa 
situação, em que o migrante responde que chegou sozinho, ninguém o ajudou, e que ele foi atrás de trabalho sem apoio de outros. Esse discurso revela que para alguns migrantes a rede social não é explicita e esses procuram mostrar em determinado momento de suas vidas que conquistaram seu espaço de trabalho, independentemente do outro, principalmente se for conterrâneo. Esse processo, que ocorreu com o paraibano, também aparece entre os piauienses.

Joaquim não veio direto para a sede da CEAGESP. Em 1975, trabalhou em Cubatão e, depois, mudou-se para o Jardim Rochdale, no Município de Osasco. Veio conhecer o Terminal por intermédio de um colega de oficina de trabalho. Foi para comprar milho e lá encontrou um conhecido. Veja o seu relato sobre a sua inserção na CEAGESP:

Aí eu vim com ele, quando eu cheguei aqui aí 'Vamos dá uma volta prá conhecer', aí teve um conterrâneo, quer dizer ele do Ceará, eu do Piauí, carregador, já inté faleceu. Aí foi falou, disse - 'Piauí, tu quer [...] carreta de melão, 20 saco, é só subi em cima do caminhão'. - 'Então, tá.' 'Segunda-feira, cedinho você teje aqui às quatro horas, prá trabalha mais eu'. Comecei a trabalha com ele.[...] Aí comecei a trabalhar, trabalhei quatro meses, cinco meses, seis meses. [...] Ele era carregador, como eu, só que eu não era. Aí, ele me chamou para trabalha prá ele; Aí, nós descarregava melão, descarregava, uva que vinha do Paraná, descarregava manga, todo tipo de fruta, nós carregava, a semana toda. Ele tinha mais ou menos, umas oito pessoas, mais eu. [...] Aí, ele foi embora e eu entrei na vaga dele. Aí eu fiquei conhecendo o CEASA. Nesse tempo todo, foi em 80, eu casei e fui embora para o Piauí, voltei em 87. Aí já vim para o CEASA, já conhecia mais ou menos aqui. Aí, eu tirei meus documentos de carregador, no dia 22 de setembro de 87.(A primeira vez que veio para São Paulo, foi em 75...) Em 80, eu trabalhei aqui quase um ano, aí eu casei e fui embora para o Norte." (Joaquim,52 anos) $)^{243}$

Nesse depoimento percebemos um processo semelhante ao da rede social estudada por nós, junto aos comerciantes de retalho no Brás ${ }^{244}$ : a relação de contrapartida que se estabelece nas redes sociais é invisível. O cearense oferece a oportunidade de trabalho para o piauiense, relação estabelecida por vínculos de confiança e, em contrapartida, o piauiense trabalha em troco de uma porcentagem, o trabalho não pago gera um maior pecúlio para o cearense, que tem a seu favor o cadastro, que se torna um "bem" que o outro trabalhador não tem. Essas formas de relações são constitutivas das construções da territorialidade presente.

Osvaldo veio de Picos (PI) e está há um ano na CEAGESP. Ele foi inserido por um vizinho. Enquanto esperava o cadastramento, trabalhava como auxiliar de seus conterrâneos. Eram dois irmãos trabalhando juntos; eles tinham um acordo para descarregar um caminhão. No caso, o valor desse serviço varia de $\mathrm{R} \$ 250,00$ a $\mathrm{R} \$ 400,00$. Osvaldo, que era ajudante

\footnotetext{
${ }^{243}$ Entrevista realizada em 29 de novembro de 2006.

${ }^{244}$ GOMES (2002)
} 
recebia o valor de $\mathrm{R} \$ 40,00$ por caminhão, o que lhe dava um ganho de $\mathrm{R} \$ 120,00$ por semana (3 ou 4 caminhões por semana). Esse valor o ajudava a pagar os custos do cadastramento. $\mathrm{O}$ carrinho foi pago pelos conterrâneos, mas depois ele pagou por esse empréstimo.

Por causa das pessoas dá uma força pra gente assim. Pessoa que é mais conhecida aqui dentro, [...] "eu quero colocar fulano, aí, a pessoa e tal..." [...] Aqui é por indicação, é tudo assim. Como uma firma, vai trabalhar numa firma, hoje em dia [...] 'Vou trazer meu irmão, trazer cunhado, trazer vizinho. Em todo lugar é assim. (Osvaldo)

Esse processo de inserção é o mais comum, pois eles usam as mais diversas expressões como “...prá me dar uma força, pra eu não ficar parado...”. Hoje Osvaldo trabalha como autônomo cadastrado, com seu parceiro, conterrâneo da mesma cidade. Depois do vai-e-vem entre Picos e São Paulo, como pedreiro, ele está há um ano e dois meses trabalhando como carregador.

Outros depoimentos revelam o papel do Sindicato no reforço e ampliação da rede social, pois para o trabalhador se inserir como carregador ele deve possuir a informação da abertura do cadastramento, e essa informação passa primeiramente pelo Sindicato. Assim, as pessoas mais próximas do Sindicato terão "de primeira-mão" essa informação e avisarão seus parentes e conhecidos sobre essa oportunidade. Entre a data da abertura e a divulgação da notícia desse processo de abertura das vagas existe um tempo muito pequeno, uma semana, ou apenas um dia. Então, o indivíduo que quer pleitear a vaga já deve estar em São Paulo, ou vir para São Paulo a tempo de conseguir cadastrar-se. Assim, esse processo de recrutamento acabou consolidando essa rede social. Vejamos outro depoimento:

Tinha essa vaga, aí eu fui e entrei nessa vaga [...] O meu sogro (piauiense) era aí de dentro e me deu um toque, aí... daqui primeiro [sindicato] e depois eu vou pra lá [cadastro]. (Samuel)

Samuel, que foi inserido pelo sogro, já inseriu o primo de sua esposa, que também veio do Piauí. Esse primo que foi avisado na área de origem, já veio com o serviço garantido por ter tido acesso à informação sobre a existência da vaga.

O que no meio empresarial pode ser chamado "reserva de mercado" vamos interpretar como a constituição de uma territorialidade, na qual o poder da informação possibilita a mobilidade do trabalho e reforça a constituição de um território. Para a Companhia, ter os carregadores indicados pelo Sindicato significa uma forma de diminuir a probabilidade de ter no espaço interno pessoas que não ofereçam confiança. Em uma área em que circula uma diversidade de pessoas "estranhas", busca-se inserir as chamadas pessoas de confiança, aquelas que são indicadas. Caso essas pessoas apresentem algum comportamento que possa 
transgredir as regras internas, como roubo, vandalismo ou brigas, esse carregador não é mais aceito no recadastramento e está fora das indicações do Sindicato.

Vejamos mais uma fala de outro carregador, que reforça a construção da territorialidade reforçando a rede social: "Naquele tempo era carta para apresentar. Hoje é diferente, é com Zé Pinheiro, aqui tem que falar com chefe aqui só se tiver aval..." (Carregador).

A rede social de piauienses é anterior à formação do sindicato, em 1990, conforme os registros dos depoentes. No entanto, o acordo entre o sindicato ${ }^{245}$ e a Companhia, de inserir seus indicados, reforça as fronteiras da demarcação desse território. A partir do depoimento acima, somado a outros registros, concluímos que os primeiros contornos dessa grande rede de piauienses se forma à medida que se exige uma carta de apresentação assinada por outro carregador, o que estimula o crescimento da rede social. Porém, esse fator isolado não justifica por si só formação dessa rede de relações.

Em vários depoimentos aparece a expressão "ter conhecimento" que, na verdade, significa ter contatos. Há uma valorização, na rede social, da importância dos contatos para se inserir na atividade, tanto nas primeiras apresentações quanto na possibilidade de ter clientes permanentes, que garantam os rendimentos. Ter algumas informações estratégicas nessa atividade garante a manutenção desse trabalhador. Vejamos análise de Ramella (1995:19) sobre a força da informação:

Por tanto, son las relaciones personales, em tanto canales de transmisión de la información, las que determinan quién tomará cuál trabajo" [...] "Em esta visión, la información no es um bien 'libre' em el mercado, disponible para todos em la misma medida: los indivíduos tienen uma información limitada, dependiente de sus redes de relaciones.

A importância da informação engloba também o conhecimento que o trabalhador urbano possui e deve repassar para o migrante recém chegado na cidade, como uma estratégia para a sua permanência, em que ele deve desenvolver não só a apropriação desse saber trabalhar no espaço urbano, mas também a chamada "astúcia", que Kowarik enfatiza em suas observações:

Em outros termos, o migrante precisa urbanizar seus conhecimentos, interiorizando, entre outros, regras e valores de distância e proximidade social, fruto das relações interclasses imperantes na metrópole. Dessa forma,

\footnotetext{
245 Encontramos no conjunto das entrevistas apenas um caso que não se refere à indicação por "cartucho", apresentação por indicação e que também não segue o caminho da rede social. O caso de Raimundo, baiano de Sapeaçu, está há dez anos no setor do Pescado. Ele foi pedir ao presidente do SINDCAR que o "ajudasse"; ele era um ex-gari desempregado, com oito filhos, em 1997. Ele atribui ao fato da sua condição de pai de família ter conseguido a vaga pleiteada.
} 
analogicamente, precisa desenvolver sua sagacidade e astúcia pessoal a fim de obter uma parcela do excedente que para muitos - vigias, faxineiros, carregadores, tarefeiros de toda ordem - é essencial como fonte de subsistência. (KOWARICK, 1993:112)

Essa rede de piauienses transbordou a categoria dos carregadores; aqueles que conseguiram um acúmulo de pecúlio compraram um box, tornaram-se permissionários e contratam, como empregado, outros piauienses. Um desses permissionários relata que é mais fácil inserir o conterrâneo como empregado do que como carregador, pois as vagas controladas pela administração do Terminal são limitadas:

O pessoal que vem aí. A minha firma aqui é uma escola. Ele vem aqui, nêgo anda sobe e desce aí, ninguém quer da oportunidade. Aí eu falo "Paga pra você, eu não pago, mas se você quiser aprende, depois que você aprende, vai chove de nêgo querendo o seu serviço. Isso depende de quem? Depende de você, eu tô te dando a oportunidade, é você que tem que trabalha"...Tem deles que se empaca, mas $90 \%$ do pessoal que eu treino, graças a Deus, arruma serviço em outras firmas bem mais fácil do que antes. Quando o pessoal chega, ninguém acredita no cara...a turma vai mais no que eu conheço - foi indicado por ele, então eu vou dar uma força. (Atacadista)

Esse atacadista é muito conhecido na sua cidade, o que leva muitos conterrâneos a lhe pedirem uma oportunidade e um apoio em São Paulo. No Terminal, seus colegas atacadistas, piauienses ou não, pedem que ele indique alguém para ser vendedor ou carregador nos boxes, que já seja treinado; então ele acaba realizando esse papel no processo de inserção dos migrantes piauienses na CEAGESP. Em contrapartida ele tem uma mão-de-obra farta e disponível com o mínimo de custo, na condição de aprendizagem, segundo o seu depoimento.

Assim, encontramos piauienses em diversas condições de trabalho: carregador autônomo, carregador clandestino, empregado de box, dono de box, ambulantes, empregado nas caixarias. Estima-se que cheguem a uns seis mil piauienses..., mas é muito difícil auferir com precisão esse desdobramento da rede social.

Entre os empregados que trabalham nos boxes, estima-se, segundo o Sindicato dos permissionários, que há 12 mil pessoas trabalhando. Esses empregados, muitas vezes, são moradores das áreas do entorno da Companhia, ou são integrantes da rede social e moram com os seus conterrâneos, ou ambos. Essa categoria é a que obtém os menores rendimentos. $\mathrm{Na}$ trajetória dos carregadores encontramos muitos que iniciaram trabalhando no box, até conseguirem cadastrar- se.

Arimatéia, piauiense de Inhuma, 22 anos, está há dois meses em São Paulo. Reside com o seu primo, que está sendo um dos seus pontos de apoio para se inserir-se como carregador cadastrado. Atualmente, trabalha como empregado em um dos boxes, onde faz o serviço de vendedor e carregador. Ele está aguardando o seu cadastramento para trabalhar 
como autônomo. Para pagar as exigências da documentação, faz carregamento. Vejamos o seu depoimento: "Feirante, às vezes, já chegaram pra carregar, mas é pouca coisa, 5 ou 6 caixas, pêssego, 4 caixas de pêssego, ele me paga a mesma coisa que um carregador, eu recebi a mesma coisa. Acho que vale a pena". (Arimatéia)

Nos primeiros dias de trabalho, ele me confessou algumas das dificuldades encontradas nessa atividade em São Paulo; nos carregamentos, chegou a derrubar caixas de melão. No entanto, o que mais o perturbava era o ritmo frenético do Entreposto:

Aqui é tudo diferente do que eu pensava que era, por que o pessoal costumava a falar o estilo que era aqui, eu achava que era mais bom. Eu até chorei para ir embora. Saudade da minha família, nunca tinha passado tanto tempo longe da minha família...Lá eu trabalhava na roça, tá entendendo? Tinha um horário assim, era sete horas da manhã, voltava às onze horas, onze e meia no máximo, a tarde ia uma e meia, duas horas, voltava lá pra cinco horas. Aqui não, eu acordo quatro horas da manhã, venho pra cá, teve vez que eu cheguei na minha casa às dez horas da noite...[...] eu trabalhava oito horas por dia, aqui eu trabalho quatorze. (Arimatéia)

Esses impactos iniciais sentidos pelo recém-chegado ficaram esquecidos na memória dos antigos carregadores em seus depoimentos. O sonho de Arimatéia é comprar uma geladeira e um fogão para a mãe, pois na sua casa só há um fogão de lenha. Ele conta que já conseguiu enviar por três vezes o valor de $\mathrm{R}$ \$ 50,00 que foram usados para alimentar a sua família. Entre seus irmãos, os dois mais velhos migraram, a primeira para Inhuma, e o segundo, para ser cortador de cana em Guaíra, São Paulo.

A maioria desses trabalhadores mora no Município de Osasco, conurbado à Cidade de São Paulo, no Oeste da Metrópole. Segue os Mapa $n^{\circ} 9$ e $n^{\circ} 10$, elaborados a partir das tabelas anexas 30 e 31. Os municípios que são servidos pela antiga ferrovia Sorocabana, como Itapevi, Carapicuíba e Jandira, consideradas cidades-dormitório, servem também como local de moradia para esses trabalhadores. Desse modo, a ferrovia tem um papel importante no seu deslocamento entre o trabalho e a residência. 


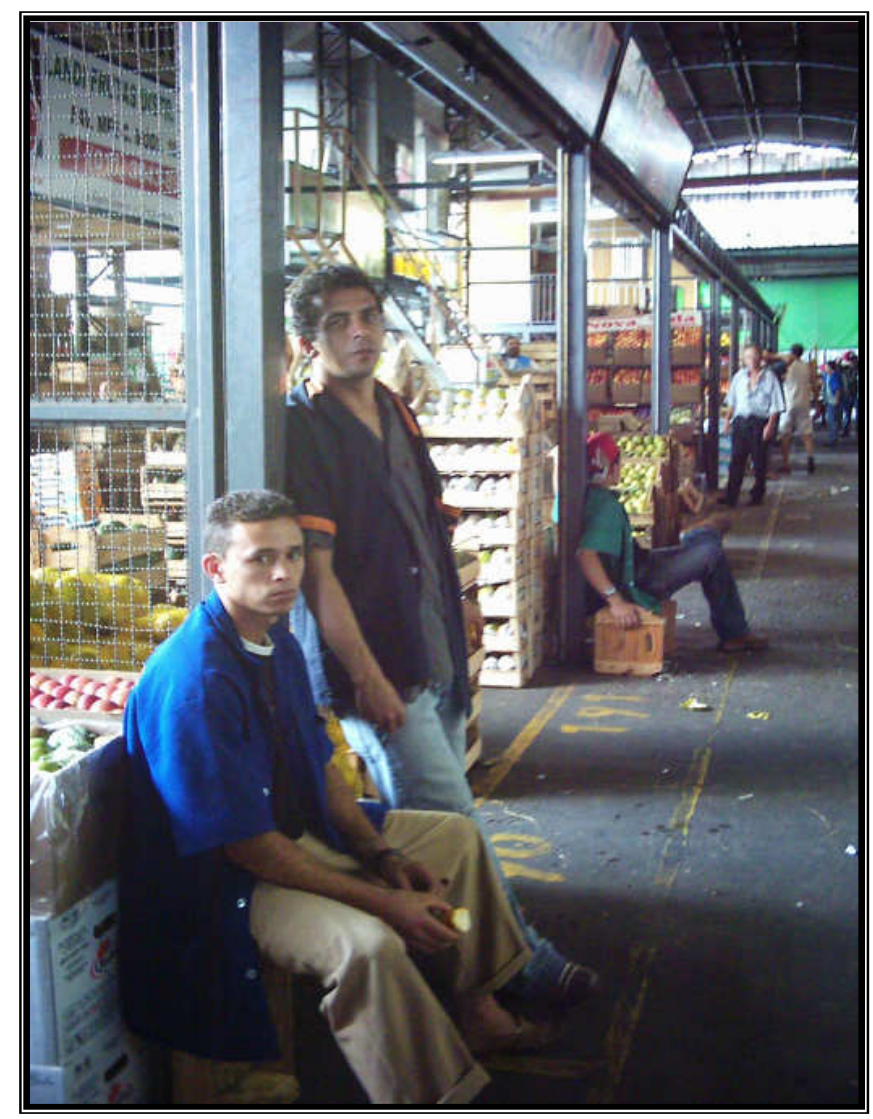

Foto 40: O atacadista, Jonas e o empregado, Arimatéia, do setor das frutas são ligados à mesma rede social da área de origem no Piauí. 
Mapa 9: Região da Grande São Paulo - Municípios de Residência dos Carregadores

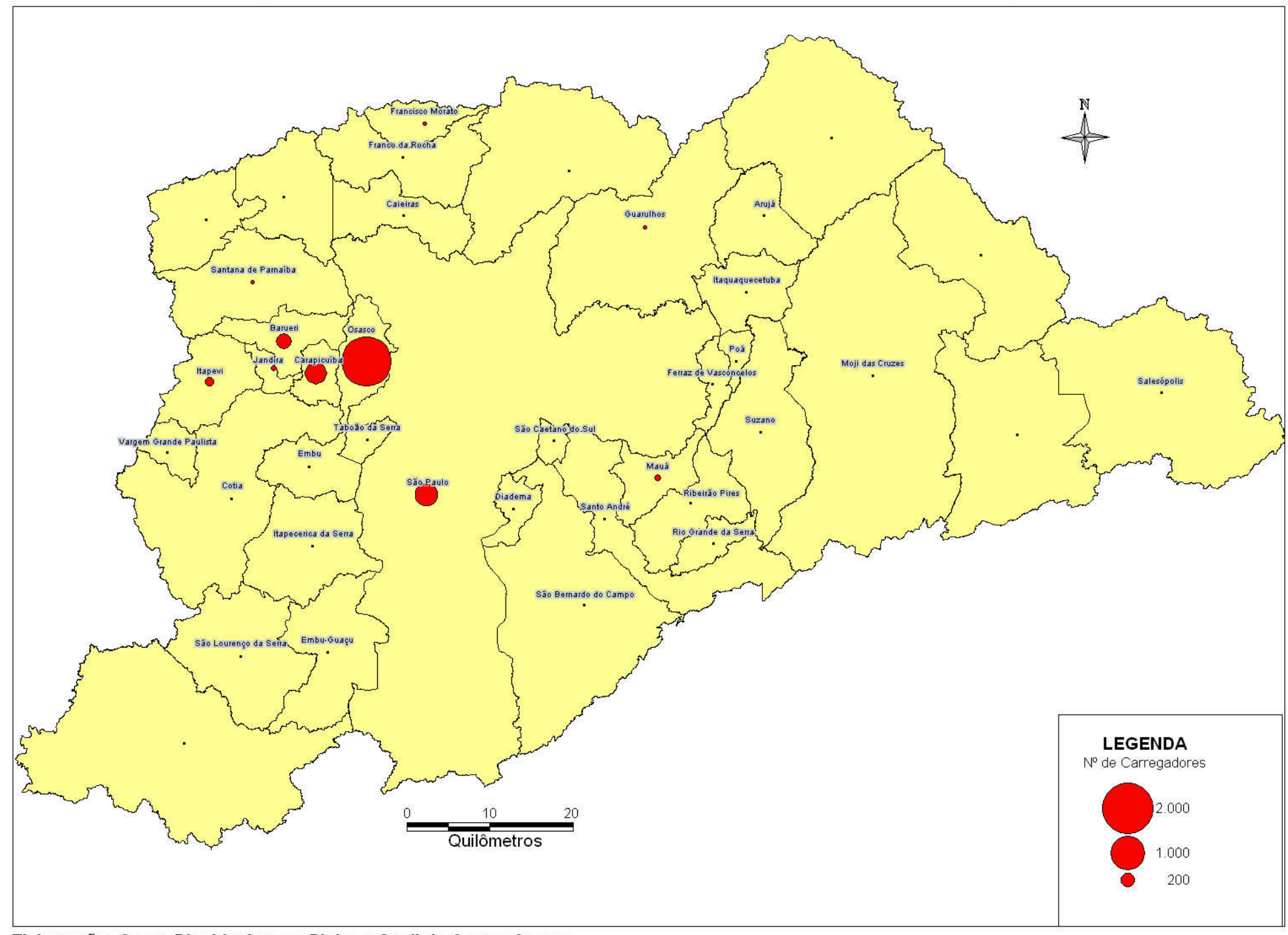

Elaboração: Geog. Rinaldo Gomes Pinho e Sueli de Castro Gomes

Fonte: CEAGESP, 2006 
Mapa 10: Município de Osasco - Distritos de Residência dos Carregadores

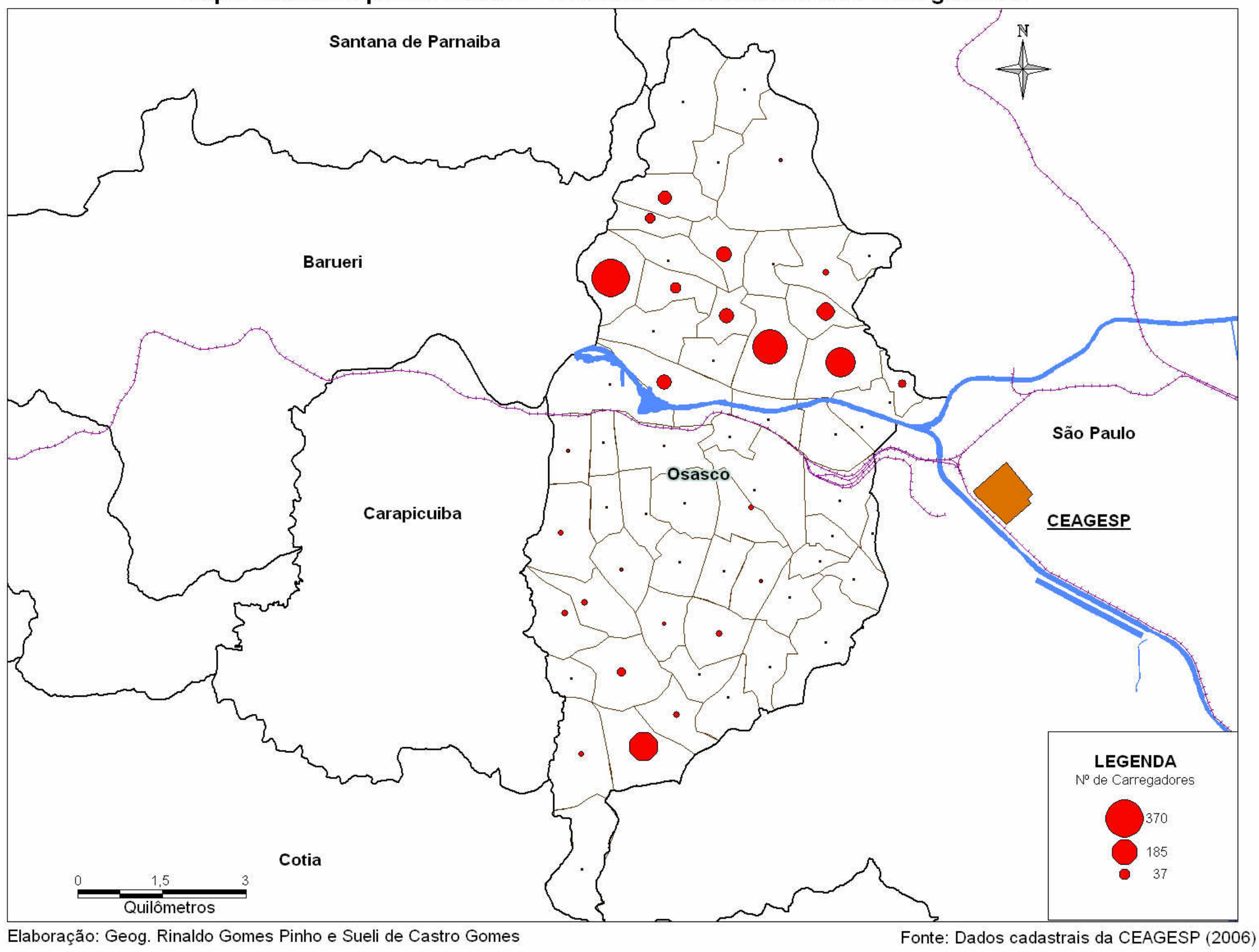


A relação entre os carregadores piauienses que moram em Osasco e o Entreposto é explicitada de outras formas. Nos eventos do Sindcar está sempre presente o vereador de Osasco, pelo Partido dos Trabalhadores, Aluísio Pinheiro. Outro episódio que demonstra a aproximação do município com a CEAGESP ocorreu no dia posterior a uma grande enchente na Cidade de São Paulo, que invadiu a área do Entreposto ${ }^{246}$. Carros de lixo do município de Osasco estavam auxiliando na limpeza do Terminal. ${ }^{247}$

Carro é poucos, vem de ônibus e de trem. [...] O Trem esse pessoal Itapevi, Jandira, Carapicuíba, Osasco. O lado de cá de Osasco é tudo trem. Agora...[...] desce aqui na Estação CEASA. Eles vão até Osasco, lá baldeia, com outro que vai para Santo Amaro. Desce aqui na porta. Pega o carrinho e saí. (Zé)

A presença da rede social na relação entre residência e trabalho se faz no dia-a-dia. Em julho de 2002, é noticiado no Jornal EntrePosto o seguinte fato. A fiscalização do município de Osasco ${ }^{248}$ estar apreendendo carros dos carregadores da CEACESP, porque estavam dando carona para amigos, familiares e vizinhos. Eles estavam sendo confundidos com carro de lotação clandestina. ${ }^{249}$.

Outro vestígio forte da manifestação dessa rede social é a presença, na rodoviária de Osasco, de linhas de ônibus, das empresas Itapemirim e São Geraldo, que atendem os municípios de origem de grande parte dos carregadores da CEAGESP.

Depoimentos apontam que alguns desses carregadores vinham para São Paulo de caminhão, até o início dos anos 90. Vinham 5 ou 6 pessoas, e cada um pagava um valor que corresponde, atualmente, a aproximadamente $\mathrm{R} \$ 50,00$. Depois, surgem com mais frequiência os ônibus clandestinos ou fretados, chamados de "Taperão". Esses cobram o valor de R\$ 160,00 , sendo que a passagem pela viação Itapemirim gira em torno de $R \$ 310,00$. Os ônibus clandestinos saem do Clube Sargento, no distrito de Rochdale, que funciona como uma rodoviária clandestina - com linhas de Osasco para o Piauí e do Piauí para Osasco.

\footnotetext{
${ }^{246}$ Fontes: Folha de São Paulo, 27 a 29 de maio de 2005 e acesso ao site: http://ultimosegundo.ig.br em 27 de maio de 2005.

${ }^{247}$ O município de Osasco, além de possuir a menor distância em quilômetros, possuia uma aproximação política, naquele período, pois, a Prefeitura e a gestão da CEAGESP, estavam nas mãos do mesmo grupo político - o Partido dos Trabalhadores.

${ }^{248}$ Quando fui a Prefeitura do município de Osasco, para conseguir uma mapa, conversei com um estudante de Geografia, que trabalhava no setor da área de riscos e cadastro. Ele relatou-me que tinha visitado uma rua, em que encontrou todos os seus moradores, eram oriundos de um único município do Piauí, informação que veio ao encontro constatáveis de nossos estudos.

${ }^{249}$ Em 2001, o caso ocorreu com o carregador Antônio Neto dos Santos e com seu irmão Adaílson João dos Santos em outro automóvel. Em junho de 2002, o caso ocorre com o carregador José Itamar de Souza. Fonte: Jornal: EntrePosto, agosto de 2002, p. 21.
} 
Somente na década de 70 , houve um crescimento populacional nos municípios de Carapicuíba e Osasco de 72\% . Esse crescimento ocorreu devido ao intenso fluxo migratório que se instalava na Região Metropolitana da Grande São Paulo, configurando um espraiamento da Metrópole. ${ }^{250}$

Por fim, uma breve consideração sobre o retorno de nordestinos, que se contabiliza em torno de 475 mil pessoas ${ }^{251}$. Esse processo aparece de forma tênue entre os carregadores, mas esses não passam incólumes a essa mobilidade. Em uma das entrevistas, depois de desligado o gravador, um dos carregadores nos contou que sua esposa resolveu retornar para o Piauí. Seus móveis já tinham ido, mas ele não quis ir. Está com quase 70 anos, seus filhos já estão casados e têm suas casas. Então, ele vai ficar morando sozinho. Lamenta e confessa, com mágoa, que sua esposa parte no dia seguinte à nossa entrevista e vai deixá-lo -“Os nordestinos não tem coração!". A mobilidade do trabalho reorganiza o capital e desorganiza os corações, esfacela as relações primárias, como o núcleo familiar.

\subsection{A rede social em outros interstícios: as cafezeiras}

A atividade dos carregadores é eminentemente um trabalho masculino, demarcando esse gênero para as funções que exigem esforço físico. Não encontramos nenhuma mulher executando essa tarefa, ainda restrita aos homens. Para as mulheres, cabe no Terminal a atividade de servir os cafés. Aquelas que realizam essa tarefa são as denominadas cafezeiras. Há uma clara divisão do trabalho segundo o gênero no espaço do Entreposto. Existem alguns homens, que entre as cafezeiras, executam essa atividade, porém são exceções. Encontramos essas mulheres empurrando seus carrinhos com garrafas térmicas e outros acompanhamentos, como lanches. As carregadoras cadastradas vestem um avental branco e seguem as normas estabelecidas pela Empresa, como: não é permitido comercializar bebidas alcóolicas, o seu carrinho deve ser numerado, etc.

Essas mulheres, em parte são oriundas do Nordeste brasileiro, principalmente do Piauí. Elas estão ligadas à mesma rede social que se formou na Companhia através da inserção dos carregadores piauienses.

Podemos dividir as mulheres que comercializam café no Terminal em três grupos distintos: o primeiro grupo é formado pelas cafezeiras cadastradas, o segundo grupo é

\footnotetext{
${ }^{250}$ In CUNHA, José Marcos. Expansão Metropolitana na transição migratória - o papel dos subcentros regionais in: SP em Perspectiva. SP. SEADE.1995

${ }^{251}$ Fonte: PNAD (2004)
} 
formado pelas cafezeiras clandestinas; e o terceiro grupo, numericamente muito inferior aos dois primeiros, são mulheres que comercializam café, mas também atuam no campo da prostituição.

Essas cafezeiras, em geral, diversificam as suas jornadas de trabalho e os espaços de atuação dentro do Entreposto. Elas acompanham os horários de funcionamento do mercado: o Mercado do Peixe acontece nas madrugadas, quase todos os dias, o Mercado das Flores, das 2:00 horas até às 10:00 horas de terças e sextas-feiras, os setores da Batata, Legumes e Frutas, funcionam de segunda a sábado, durante todo o dia. Em qualquer horário, encontramos essas mulheres empurrando seus carrinhos com as garrafas térmicas.

As cafezeiras cadastradas têm uma Associação e um espaço alocado para dar apoio a esse trabalho, em particular, na preparação dos cafés. Elas formam um grupo de 174 cafezeiras cadastradas. Era um grupo bem maior em 2001, 236 cadastradas. No entanto, houve desistências, bem como o fato da Companhia ter fechado o cadastramento ${ }^{252}$. Essa atividade sofre o mesmo processo de redução de vagas observado entre os carregadores, consequiência da diminuição do fluxo comercial do Terminal.

Cada unidade de café custa o valor de setenta e cinco centavos de real ${ }^{253}$. Os rendimentos das cafezeiras variam de acordo com a quantidade de cafés servidos por dia. Pode-se encontrar algumas das mais antigas cafezeiras que conseguiram acumular pecúlio, como casa própria, automóvel e casa de aluguel. Essas cafezeiras vendem café avulso, mas também comercializam garrafas térmicas todos os dias para os atacadistas. Uma das cafezeiras $^{254}$, piauiense do município de Pio IX, fornece aproximadamente quarenta garrafas térmicas para determinados atacadistas; ela cobra bruto de $\mathrm{R} \$ 4,00$ a $\mathrm{R} \$ 5,00$ por garrafa térmica. Isso significa um rendimento diário de $\mathrm{R} \$ 200,00$, apenas com o fornecimento das garrafas térmicas. Devemos considerar os custos dessa atividade, como as diversas taxas e impostos que são pagos: cadastramento e sua renovação anual, previdência social, além do custo para a produção da bebida. De modo geral, os rendimentos das cafezeiras que fornecem café para os permissionários atacadistas ${ }^{255}$ são melhores do que daquelas que vendem apenas o cafezinho avulso.

Elas passam o dia todo empurrando o carrinho, disputando espaço com os carregadores e compradores em corredores estreitos, reservados para a circulação entre os

\footnotetext{
252 Informação que obtivemos em agosto de 2006, pois o cadastro estava fechado há mais de dois anos e até o momento não havia previsão de abertura.

${ }^{253}$ Informação obtida em dezembro de 2006.

${ }^{254}$ Ela é irmã do Presidente do Sindicato dos Carregadores, e tem uma parte de sua família trabalhando na CEAGESP como sobrinhos, filho e irmãos.

${ }^{255}$ Conforme a CEAGESP são 3800 permissionários, cuja maior parte é atacadista.
} 
boxes de flores, frutas, legumes, pescados,... . Veja a descrição desse esforço - “...Tem outra que não pode nem andar, com o joelho desse tamanho, assim inchado, de empurrar carrinho..." (Carregador). Essa atividade gera problemas de saúde como varizes, resultado da necessidade de se permanecer em pé por muitas horas. Segundo a médica do Sindicato dos Carregadores, que atende também as cafezeiras, existe uma grande incidência de problemas cardíacos entre essas mulheres, gerados pela alimentação gordurosa, típica da culinária nordestina, presença do cigarro e estresse.

A clientela das cafezeiras é formada pelos atacadistas, carregadores, funcionários dos boxes, e também por compradores do Terminal, que dependendo do setor em que elas atendem, podem ser feirantes, distribuidores, pessoas que compram no varejo. Há, também um grande número de caminhoneiros que passam o dia no entreposto, tanto para descarregar como para carregar, que compram os cafezinhos dessas mulheres. Os compradores com mais recursos preferem se servir do café nos quiosques, lanchonetes e padarias espalhadas pelo Centro de Abastecimento.

As mulheres que comercializam café possuem idades diversificadas. Observamos, no entanto, entre as cafezeiras cadastradas um menor número de jovens, enquanto as clandestinas apresentam desde adolescentes até senhoras de idade avançada. Outra característica dessas mulheres é o baixo nível de escolaridade, pois a atividade não exige qualificação.

Alguns carregadores entrevistados possuem vínculo familiar com as cafezeiras, como o de esposa, irmã ou mãe. Entretanto, uma parcela dos homens respondeu na entrevista que suas mulheres não devem trabalhar fora de casa, muito menos no Entreposto. O nosso ponto de partida, para chegarmos à problemática que vivenciam as cafezeiras em um território masculino, foram as informações obtidas junto aos carregadores. Vejamos essa justificativa: “A maioria são meio machista. Então acontece, assim, eu tirei ela daqui e não quero que ela volte mais. Não é por mal. Ele tem medo dos amigos zuá ${ }^{256}$. (Carregador do Piauí)

As maiores dificuldades estão entre as mulheres que não conseguiram se cadastrar e trabalham em uma condição de clandestinidade. Elas não seguem as normas e o padrão estabelecido pela Companhia e, portanto, são facilmente identificadas. O preço do café avulso de uma cafezeira cadastrada sai por $\mathrm{R} \$ 0,75$, enquanto a clandestina cobra o valor de $\mathrm{R} \$ 0,50$. As clandestinas podem utilizar-se de carrinhos de feira ou sacolas para transportar as garrafas térmicas. Algumas usam veículos muito antigos como apoio e utilizam seu porta-malas para colocar os lanches e o café. Outras carregam caixas de "isopor". Enfim, é uma situação de

\footnotetext{
${ }^{256}$ Zuá é uma gíria que quer dizer fazer brincadeiras de mau gosto com uma pessoa.
} 
total informalidade. Segundo depoimentos de carregadores, essas trabalhadoras algumas vezes são confundidas com as prostitutas que circulam nos mesmos locais, e passam por situações de constrangimento, como veremos no depoimento a seguir:

É mais as clandestinas que os caras fazem o que quer, porque sabe que é clandestina, fica passando a mão, né? Fica se humilhando pra vender cafezinho dela. Agora, agora quando você tem o documento... Vem o fiscal, eu não vou correr. Se elas vêem os fiscais, ela tem que correr, mesmo, toma as garrafas. Ela não pode falar nada, que ela é clandestina. (Carregador, filho de cafezeira)

A condição de clandestinidade às coloca constantemente em situações de constrangimento e alerta, para não cair na rede da fiscalização, já que não têm condições de requerer nenhum direito. $\mathrm{O}$ constrangimento se torna rotina entre essas mulheres. Vejamos outro relato:

Sabe como é que é? O homem sempre fazendo aquelas piadinhas, né? E Tal.. Tem delas aqui que ...até uma que jogou café quente nos caras, aí. Os caras fizeram troça e elas não gostaram e...se defendeu. (Carregador da Bahia)

Nos dias de trabalho de campo pudemos assistir diversas vezes homens chamando a atenção dessas mulheres, que carregam nas mãos as garrafas térmicas, fazendo gracejos, piadas, rindo em voz alta.

A área do Terminal é um espaço de grande concorrência entre as cafezeiras, cadastradas e as clandestinas. As mulheres que conseguiram o cadastramento cobram eficiência da fiscalização, pois há competição pelos clientes. As cafezeiras regulares sentemse lesadas, pois pagam as taxas que garantem a regulamentação de seu trabalho, enquanto as outras, representam a concorrência numa situação de desigualdade, pois vendem o café sem o custo das taxas de regularização.

A existência do estigma da prostituição, que afeta todas as mulheres que comercializam o café, é na verdade resultado de uma abordagem preconceituosa por parte dos homens, que trazem com eles o resquício do machismo da área de origem e que migra para o espaço masculinizado do Terminal. Muitos desses homens, que generalizaram a prostituição, se opõem à possibilidade da mulher trabalhar fora de casa. ${ }^{257}$

Há uma grande quantidade de mulheres que trabalha na clandestinidade. No entanto, o número de cafezeiras regulamentadas vem apresentando uma redução, pois o cadastro está

\footnotetext{
${ }^{257}$ Uma outra parte dos carregadores, em entrevista, defende as cafezeiras e se dispuseram esclarecer melhor sobre o processo do estigma da prostituição. Todos afirmavam que havia algumas presentes no grupo das clandestinas que usavam a dupla prática, do comércio do café e prostituição.
} 
fechado por tempo indeterminado. A diminuição de possibilidade de trabalho no Terminal não atinge só o carregador, mas todos os ambulantes, resultado do declínio do fluxo comercial que esse Centro de Abastecimento observou nas últimas décadas,gerado pela descentralização do abastecimento. A modernização do abastecimento levou à redução das feiras-livres, comércio de hortifrutigranjeiros tradicional que foi substituído pelos supermercados. Assim, essas mulheres migrantes sofrem com o desemprego, conseqüência da redução na oferta de trabalho e do aumento da clandestinidade. que por sua vez, representa um grupo de mulheres que sofrem muito mais, na busca de alguma forma de inserção, mobilizadas pelo capital.

\subsection{Trabalho Temporário: entre o Piauí e São Paulo}

Em algumas entrevistas, identificamos trabalhadores que voltaram mais de uma vez para a sua área de origem e retornaram para o Terminal da CEAGESP para trabalhar na atividade de carregador. Como no caso do paraibano Antonio, que se cadastrou duas vezes. A situação de retorno e vai-vêm aparece algumas vezes, bem como a migração temporária. Assim sendo, se faz necessário revelar essa forma de mobilidade do trabalho.

Os dados cadastrais da Administração registram apenas a primeira entrada do carregador na Companhia. Nessa fonte de pesquisa não conseguimos captar o trabalho temporário, e nem ver, como já dissemos, a evolução do crescimento de carregadores na CEAGESP, pois só estavam disponíveis os dados mais recentes. Embora não tenhamos conseguido precisar o número de migrantes temporários, os depoimentos registraram que eles já foram mais numerosos. Houve, pois, um declínio na participação dos mesmos no universo dos carregadores ${ }^{258}$. A percepção dessa mobilidade é sutil, mas não é visível, do ponto de vista da Companhia. $\mathrm{O}$ atraso na renovação do cadastramento pode ser um indicador, pois quando o carregador não está em São Paulo ele tenta justificar a sua viagem para não ter seus registros cancelados. Assim relata um funcionário da Companhia:

Todos que vão viajar, quando voltam diz que a mãe morreu, essa é uma história engraçada, não tem um que chega aqui e diz assim - 'eu fui viajar porque eu fui passear'. Eles só chega e diz: - 'Eu fui lá, porque minha mãe morreu', eu acho isso interessante, eu não consigo por isso na minha cabeça .....que ele só vai pra lá.... Houve um dia um velhinho, já de 70 anos - 'Sr. Raimundo, eu vim pedi pro senhor, eu tô muito atrasado, eu fui viajar..'.'Não precisa mais me falar que você vai me falar que a sua mãe morreu!!!. - 'O senhor me desculpa, me ensinaram a falar isso, eu não gosto de mentira." Eles falam mesmo. Eles não assumem que foram passear, que foi

\footnotetext{
${ }^{258}$ Nas entrevistas foram citados 400 temporários, 100 temporários e até um número menor que isso.
} 
comprar um terreno. Eles não falam. Eles têm medo do cancelamento. Eles acham que sou eu que faço o cancelamento, por ele ter ido viajar. Mas, eu só faço cancelamento dentro do regulamento. Há menos que um carregador tenha agredido, algum dano material, aí envolve polícia, é um caso ou dois casos. É muito raro.

A grande rotatividade dos piauienses foi percebida no decorrer de parte das entrevistas. Ela foi apontada, inicialmente, pela médica do Sindicato, Dra. Célia Medina. Esse grupo de carregadores temporários vem trabalhar, especificamente, no setor das frutas, principalmente na safra da uva, ${ }^{259}$ pois os agricultores já têm um acordo com os temporários para descarregar seus caminhões. Esse período inicia-se em novembro e vai até fevereiro.

Evelyn (1988) estudou os migrantes temporários, mais precisamente aqueles que alternam as formas de trabalho: o trabalho agrícola com o trabalho fabril, o trabalho por conta própria com o trabalho fabril, o trabalho por conta própria com o assalariado, o trabalho no sertão com o trabalho em São Paulo. Uma parte de sua pesquisa ela realizou com migrantes que residem no distrito do Jaguaré, em São Paulo, nas proximidades da CEAGESP:

O grupo que estudei trabalha em fábricas do Jaguaré, Osasco, no próprio ABC. Muitas vezes são carregadores no CEASA ou em frigoríficos. Isso para não falar na construção civil por onde todo mundo já passou (EVELYN, 1988: 21).

Em outra parte da pesquisa ela menciona que uma parcela dos seus entrevistados trabalhava nos boxes de hortifrutigranjeiros do Terminal. Seus estudos contribuem na reflexão sobre o significado do que é ser um trabalhador temporário urbano, haja vista que a maior parte dos estudos sobre trabalho temporário aborda a temática do trabalho temporário no campo $^{260}$. Essa pesquisa possui um elo com os nossos estudos na medida que faz uma reflexão sobre os migrantes que se inseriram no Terminal de Abastecimento como carregador, na condição de trabalhador temporário. Esses carregadores residem próximo do Terminal, fato justificado, pela economia de tempo e dinheiro no seu deslocamento até o trabalho ${ }^{261}$.

Evelyn (1988) analisa as diferenças entre o trabalho no campo e o trabalho na cidade. Trata do migrante de origem camponesa que migra para a cidade, como sugere os estudos de Durham (1973). O objetivo desse migrante seria a manutenção da vida no sertão nordestino, ou, como discutido por outros autores ${ }^{262}$, a manutenção da vida camponesa. Assim, a autora compara as diferenças de condições de trabalho e vida (remuneração, qualificação, problemas, jornada de trabalho, tempo livre, lazer, condições de moradia) na cidade e no campo. O

\footnotetext{
${ }^{259}$ Em uma entrevista apareceu referência à safra de uva Niágara de Itatiba.

${ }^{260}$ Maria Aparecida de Moraes ( 1999)

${ }^{261}$ EVELYN(1988)

${ }^{262}$ MARTINS (1979) em Cativeiro da Terra
} 
trabalho na cidade é vivido como um 'cativeiro' pelo homem do sertão do nordestino, vejamos:

\begin{abstract}
O homem do campo valoriza ao extremo essa liberdade, como eles chamam, e segundo nos conta Eunice quando migram definitivamente para a cidade preferem muitas vezes um trabalho menos remunerado e com mais autonomia. (EVELYN,1988:29)
\end{abstract}

A atividade dos carregadores representaria uma certa 'autonomia', por ele não estar vinculado a nenhum patrão diretamente. Sua remuneração dependerá do seu esforço. A sua identidade vincula-se ao trabalho autônomo. Assim: "O migrante 'fixa' o necessário para manter a sua sobrevivência se prestando a qualquer trabalho...Eles sempre recomeçam da estaca zero. Portanto não há carreira para o migrante temporário”. (EVELYN, 1988: 24).

A autora caracteriza desse modo o trabalho temporário: pior remuneração, piores condições, ritmo alucinado, sem qualificação, jornadas longas. A história de trabalho desses migrantes é permeada por doenças, acidentes, seqüelas provisórias ou permanentes e até mortes. Eles assumem as tarefas mais insalubres, como pudemos observar na atividade dos carregadores. Nossos entrevistados responderam que, na época em que estão em São Paulo, mesmo sendo o período de chuvas no Piauí, logo, bom para plantar, os rendimentos de lá não compensam, comparados com o que eles podem tirar no período de alta na CEAGESP. O que eles levam um mês para ganhar no Piauí, ganham em pouco tempo no Terminal. Assim, o rendimento é um fator fundamental, que ele diferencia no seu trabalho na área de origem com a atividade no Centro de Abastecimento.

Esse carregador temporário procura obter rendimentos que possam pagar a passagem de sua viagem, a moradia, as despesas com a renovação do cadastro e outras taxas, como a exigida para guardar seu carrinho no galpão do Sindicato no período em que ele está no Piauí. Para compensar, deve sobrar um valor para que ele possa retornar para seu local de origem, para a sua manutenção. Ulisses, funcionário da Prefeitura de São José do Piauí, tirou licença e férias para poder vir trabalhar em São Paulo na temporada e responde sobre seus rendimentos:

Ajuda, vem cobrir a despesa da gente, porque lá ganha pouco na Prefeitura e não dá o suficiente, pra gente, porque agente tem que ter um pouquinho, uma reservinha, no caso de qualquer problema de saúde. O que agente ganha só dá para se manter [...] precisam um pouco de reserva pra resolver. (Ulisses)

O trabalho no Terminal da CEAGESP exige grande esforço físico e um ritmo que acompanhe a circulação da mercadoria alimentos, que tem hora para ser comercializada, em razão desua perecibilidade. O carregador deve acompanhar o ritmo dos feirantes, que chegam 
na madrugada para se abastecer das mercadorias que vendem. É um ritmo desumano, com jornadas prolongadas, muito diferente do campo, que segue o ciclo da natureza. ${ }^{263}$

O migrante temporário que chega a uma certa idade, na qual está impossibilitado para exercer o trabalho de carregador, pois esse exige um esforço que já não pode realizar, é descartado. Então, sua aposentadoria coloca-se como problema, pois como carregador temporário não contribui para a Previdência Social. Alguns entrevistados revelaram que alguns carregadores pensam na aposentadoria concedida aos homens do campo.

Em relação às redes sociais, Evelyn e Durhan indicam que o trabalhador temporário possui uma rede simples e um pequeno acesso ao uso da cidade, em função de sua baixa renda e do pouco tempo livre que possui. Nossas entrevistas apontam para a importância da rede social para esse migrante, que fica alojado na casa de parentes. O seu tempo-livre ele utiliza para ficar em casa descansando ou para visitar parentes e conterrâneos que moram em São Paulo. Exercitam assim a prática da "visita", não se preocupando em "fazer uso da cidade".

Durante o período da pesquisa, alguns carregadores afirmaram que iam sair dali, devido aos baixos rendimentos, ou porque estavam migrando para outra cidade, ou retornando para o lugar de origem. Eles desapareciam. Depois, no outro ano, observamos seu retorno. Indagando sobre o retorno desses carregadores ao trabalho no Entreposto, ouvi a seguinte resposta: "Pessoas que entram aqui não saí daqui. É uma água doce. É o dinheiro na mão toda hora e esse dinheiro é uma praga". (Sr. Leovergildo).

E também, de outro entrevistado, resposta no mesmo sentido. "Aqui a água é doce, a pessoa não consegue sair". (Eduardo)

A possibilidade de obter dinheiro imediato, isto é, logo após a realização do trabalho, estimula a permanência desses carregadores e o seu retorno à atividade, quando esses comparam os ganhos em outros espaços de trabalho, como no campo, em que as dificuldades de trabalho são maiores e rendimento são menores. No Terminal eles acreditam ter algumas garantias, nem que sejam imaginárias. Estar no Entreposto parece estar associado a outras representações, como espaço de encontro, lugar ou território conhecido. Daí a expressão "água doce".

Esses trabalhadores vêm para o Terminal da CEAGESP no período entre novembro e dezembro, períodos de grande fluxo comercial, e retornam para as suas roças nos meses de fevereiro e março, quando declinam os rendimentos. O município de origem da maior parte desses trabalhadores temporários é São José do Piauí. Gira em torno desses carregadores

\footnotetext{
${ }^{263}$ Henry Lefebvre em sua obra A Vida Cotidiana no Mundo Moderno discute o ritmo imposto sobre o tempo na Modernidade em que se tudo é contado e quantificado, segundos, minutos e horas.
} 
constantes brincadeiras, chistes sobre a fidelidade de suas esposas, pois nesse período o município fica povoado por mulheres. Vejamos o depoimento de um carregador, extemporário que se fixou de uns três anos para cá, caracterizando essa migração:

A maioria que vem temporão, eles tem comércio, lá, bar, essas coisas, quando ele vem pra cá, a mulher fica tomando conta, é três ou quatro meses, a maioria desses pessoal temporão, outros tem carro... Mudou muito, o negócio aqui tá muito devagar, eles vinham mais para a safra da uva, não é mais daquele jeito, quando eu cheguei aqui eu descarregava para 13 produtores, hoje nós, se nós pegar..., ainda tem a descarga, só é em cinco pessoas, oito já pararam. Eles tão mandando pra outras pessoas vende ... mercados grandes, Carrefour [...] É por isso que ta mudando. (Renato)

Deste modo, diferentemente das pesquisas que tratam a migração temporária como uma forma de manutenção do camponês, de sua propriedade e seu modo de vida, registramos no nosso estudo uma migração temporária de migrantes de área urbana, que possuem atividades urbanas, como comércio, emprego público, serviço de transporte escolar e transporte em geral.

Outro elemento fundamental para entender a diminuição dessa migração temporária é a (re)estruturação da circulação da mercadoria, reduzindo os rendimentos dos temporários. ${ }^{264}$ Vejamos mais:

Tem deles que comprou carro, lá e fica transportando pessoal, aí eles vêm pra cá, porque é férias dos muleques, os meninos que estuda, tem outros que carrega aluno, comprar uma D20. é o que eu quero fazer, pretendo comprar uma D20, um carro no futuro. Lá não usa muito perua escolar, usa mais D 20, porque lá onde eu moro mesmo é sertão, mesmo, é terra. Aí ele usa a D20, porque eles é obrigado a fazer uma (adaptação)... o carro é que eu pretendo, muito que vem prá cá, conseguiram um bom dinheiro, juntaram, eles tem isso aí, tem o Bar e tem o transporte de transportar gente, pra feira, pra cidade do interior, é muito melhor, né. [...] transporta as pessoas e você não querendo transportar as pessoas, transporta só as crianças, alunos da escola, o Prefeito já paga, prefeitura já paga salário” [...]” alguns ainda vem prá cá, porque é as férias das crianças, eles aproveitam, vem prá cá arranjar um dinheirinho e outros já não vem mais, a maioria não vem mais. (Renato)

Muitos dos migrantes, assim que conquistam um pecúlio que lhes garanta um negócio próprio e uns trabalhos para a sua manutenção, deixam de migrar. Outros ainda fazem o vôo das andorinhas ${ }^{265}$ para complementar a renda. O sonho de Renato, como de muitos, é se instalar, trabalhar com o transporte utilitário e ter seu bar. Ele já está pesquisando o preço de

\footnotetext{
264 Antigamente, eles faziam uma retirada de $\mathrm{R} \$$ 500,00 reais na melhor semana, do Natal. Essa semana apresenta o melhor rendimento do ano. Em 2006, nesse período, muitos não conseguiram o valor de R\$300,00. Considerando as despesas para se manter cadastrado, somada a viagem para tal empreitada, os rendimentos livres são bem menores.
}

${ }^{265}$ MARTINS (1988 b) pp.43-61 
uma mesa de bilhar para o início do negócio. Pretende, assim, retornar em definitivo para a sua cidade, que ainda não possui energia elétrica, como desabafa. Os rendimentos obtidos por esses migrantes vão alterando a paisagem urbana da sua área de origem, levando para lá o que existe de novidade na metrópole de São Paulo.

A maior parte dos trabalhadores temporários desses municípios migram para trabalhar na cana-de-açúcar no Interior de São Paulo, enquanto um grupo reduzido migra para trabalhar no Terminal da CEAGESP. Esse tem suas vagas limitadas pelo controle do cadastramento, isto é, regulado pelo Estado. Encontramos em algumas pesquisas ${ }^{266}$ referência sobre o fluxo de piauienses para as lavouras de cana-de-açúcar. Mezgravis (2006), nos seus estudos sobre os "chapas" na região de Ribeirão Preto, encontrou esses migrantes trabalhando nessa atividade, junto ao Sindicato dos Movimentadores de Carga, que funciona como uma espécie de empreiteiro de mão de obra. Eles já não conseguem ocupação no corte da cana, como bóias-frias, e são mobilizados para a atividade de carregador. Segundo o autor, são chamados “de 'nortistas' ou de 'Piauí', referências pejorativas dos trabalhadores que vêm do nordeste brasileiro, especialmente os do Piauí.". A expressão "baiano" acabou se generalizando para todo aquele migrante que vinha do Nordeste. ${ }^{267}$ Esse estigma recebe uma conotação pejorativa, de grotesco, estúpido e ignorante. Contudo, nessas áreas em que os piauienses estão se inserindo, a expressão "baiano" tem sido substituída por "Piauî".

Em nossa área de estudo, ouvimos caminhoneiros, feirantes e outras pessoas chamarem esses homens de "Piauî". Essa denominação acaba sendo uma espécie de apelido. Entre eles, também é comum usar o sistema de apelido. Conhecemos alguns, como “Chapolim", "Urubu”, “Já Morreu”, "Bebezinho”... Vejamos a fala do Sr. Mateo, quando ele trata da relação diária de trabalho entre os carregadores - " 'Vamô carregar um caminhão'. 'É tanto, a divisão da partilha, é certinho. O caminhão é tanto.' - 'Tá, chama o 'Americano' prá te ajudar'” Ele se refere ao parceiro, cuja denominação significa 'bobo', daí a origem do apelido.

O fluxo migratório é tão recorrente, que um dos carregadores, aproveitando-se desse fato, garantiu para si dupla fonte de rendimento. Além de ser carregador no Terminal, possui um ônibus que faz a viagem, dos trabalhadores temporários e outros piauienses, para a área de origem. Além de alimentar a rede social dos piauienses da CEAGESP, contribui para esse vai-

\footnotetext{
266 Andréa Vettorassi, em exposição sobre Guariba, cidade próxima de Ribeirão Preto, e também sobre os trabalhadores da cana-de-açúcar, se refere ao fluxo de Piauienses. Sua exposição ocorreu no seminário sobre trabalho temporário, no Fórum Social das Migrações, em janeiro de 2005.

${ }^{267}$ Ver mais PÓVOA NETO (1994) e PENNA (1992)
} 
vêm entre o Piauí e São Paulo. De vez em quando, ouve-se dizer que seu ônibus está quebrado na estrada, mostrando as dificuldades encontradas nessa viagem..

Uma pequena parte dos migrantes é, portanto, constituída por carregadores que são trabalhadores temporários. No entanto, a grande maioria já se fixou em São Paulo com a família e não pretende retornar, como mostra o depoimento, a seguir:

Não, pro Nordeste é pouco que retorna. Algum é pouquíssimo. Pro Nordeste, nós tem aquele problema Nordeste, falta de chuva. Chove um ano, agente já fica com a cabeça levantada se no outro ano chove, porque se o Nordeste chovesse todos os anos, muitos não vinha prá cá, então o cara vem prá cá se é (... )..sabe que prá voltar não dá.(Zé)

No entanto, em algumas entrevistas, faz-se menção à carregadores que retornaram para a área de origem, ou à carregadores que estão retornando, devido à redução de trabalho no Terminal:

Eu conheci. Não conseguiu tirar documento de carregador. Tem uns que merece, como diz, eles vem e não encontra a oportunidade na firma, uma chance pra mostrar o seu potencial, não quer ou não se adequaram aí termina voltando. (Anônimo)

Assim como para os carregadores permanentes, aos carregadores temporários, habituados ao vai-e-vem, se coloca, com o tempo, a questão da permanência definitiva em São Paulo ou de retorno às áreas de origem.

\subsection{As metamorfoses da metrópole: estilhaços da migração}

Encontramos na imprensa escrita, nos depoimentos e nas conversas com freqüentadores do Terminal da CEAGESP revelações sobre a prostituição, jogos de azar, tráfico de drogas e matadores de aluguel. Nesse sentido, pretendo desenvolver, parcialmente, essa face oculta da Central de Abastecimento e analisá-la no processo de metropolização e de sua modernização.

\subsubsection{Os estilhaços de um espaço fragmentado - entre a prostituição, os jogos e o tráfico}

Existe um cordel do cearense Abraão Batista (1991) denominado de "Ana Paula, a jovem que se rifou para ir morar em São Paulo”. Esse fato, registrado no cordel, teria 
ocorrido em Juazeiro do Norte, entre o final de agosto e o começo de setembro de $1991 .^{268}$ Nossa hipótese é de que a prática desse tipo de rifa tenha migrado do Nordeste para a metrópole, mantendo-se por um bom tempo nos corredores do Terminal da CEAGESP. Era muito comum mulheres rifarem o seu próprio corpo. Elas ofereciam um bilhete numerado aos carregadores, atacadistas e a homens que circulavam no Entreposto. A rifa corria pela loteria federal. O prêmio dava direito a passar uma noite em um motel, com direito a jantar e a "companhia" da mulher que estava se rifando. Era o único lugar em São Paulo, conhecido pelos nordestinos, em que acontecia essa forma de prática de prostituição. Após o ano de 2000, essa prática foi desaparecendo e não se ouve falar mais dessas rifas, somente da prostituição nos moldes tradicionais. Alguns depoimentos apontam que a atual gestão da Companhia $^{269}$ priorizou a fiscalização contra essa prática, e isso foi um dos fatores responsáveis pelo desaparecimento das rifas de mulheres. Devemos lembrar que esse período também é marcado por uma forte migração de retorno. A prática da rifa, documentada no cinema e nos cordéis, é utilizada como uma das estratégias para as mulheres conseguirem a passagem de ônibus necessária para realizar a migração. A diminuição da rifa de mulheres no Entreposto está relacionada, também, com a diminuição das oportunidades de trabalho em São Paulo e com a necessidade do retorno para a área de origem.

O Terminal é um local em que ainda ocorre a pratica da prostituição, que muitas vezes passa despercebida entre as 50 mil pessoas que circulam todos os dias nessa área. Essa atividade concentra-se no setor das frutas, conforme apontam os depoimentos e o que pudemos observar em campo. Outro indicador dessa prática são as várias casas de prostituição nas proximidades do Terminal e da Estação Ferroviária da Vila Leopoldina.

Atualmente, o mais comum é encontrarmos no Entreposto a rifa de motos e carros. Esses homens que atuam na CEAGESP são chamados de “rifeiros”. Há também um grande número de outros jogos nesse local. Observamos ao longo do dia, em todo Terminal, e particularmente no setor das frutas, muitas pessoas trabalhando com o jogo do bicho, e, em especial, muitas mulheres. Elas se concentram em determinados locais, como quiosques e oficinas de carrinhos dos carregadores, para anotar as apostas. Essa atividade não apresenta nenhuma dificuldade de inserção, possibilitando uma grande absorção de desempregados da metrópole.Vejamos o artigo da imprensa escrita sobre esta modalidade:

\footnotetext{
268 No ano de 2006, as telas do cinema exibiram um filme denominado "O céu de Suely”, direção de Karim Ainouz, que retrata essa experiência da rifa como uma estratégia para migrar.

${ }^{269}$ Gestão do Governo Federal assumida pelo Partido dos Trabalhadores, sendo o Presidente da República Luiz Inácio Lula da Silva.
} 
Um dos maiores negócios do mercado paralelo são os jogos. O jogo do bicho possui 27 bancas espalhadas em vários pontos da Companhia. A movimentação segundo a Folha apurou, chega a 30 mil por dia. É fácil observar os bicheiros no final da tarde recolhendo o dinheiro, especialmente na área de frutas. (F.S.P. 18.11.2001)

Outra modalidade de jogo que toma o tempo de folga dos carregadores e de outros trabalhadores da Companhia é o "jogo do bozó”. Os apostadores se reúnem em torno de uma caixa de madeira e buscam compensar o dia fraco jogando dados. Cada jogador aposta R\$ 10,00 em um número dado, quem acertar o número ganha o prêmio (a soma do valor que foi apostado). Existem "quadrilhas" que atuam na CEAGESP aplicando o golpe de jogar com dados viciados. Muitos trabalhadores acabam caindo na cilada e perdem tudo que têm no bolso. Vejamos o depoimento do Sr Leonides sobre o que foi a presença do "bozó":

Até a camisa. Eu via muito, às veis, o dono do Bozó, quando ele perdia tudo, eu dizia toma dez,... ele não tinha nem... toma dez conto. Então, um fracasso.[...]trinta anos aqui tinha Bozó, mesmo e agora sumiu.

Outro piauiense responde sobre a presença dos jogos:

Tem, mas pessoas que fazem jogo aqui é o trabalho dele. [...] A vida é assim, tem outros vence aqui no comércio, outros já perde tudo que tinha, todo meio de trabalho.(Jonas)

Outro depoimento:

Muito jogo. Todos jogos, jogos do bicho, baralho, dominó, bozó, [...] meio escondido, mais tem. (Samuel)

Essas práticas de jogos fizeram com que os trabalhadores se referissem como "Cassino", para indicar essa face do Terminal de Abastecimento. Aliás, próximo do Entreposto, pode se ver uma grande Casa de Bingo, na avenida Gastão Vidigal.

O "submundo" do roubo e das drogas se revelou à medida que desenvolvíamos a pesquisa. Segundo a imprensa escrita ${ }^{270}$, na Companhia há pessoas que furtam caixas e as revendem por centavos. Há outros tipos de furtos, segundo os carregadores, como os roubos de dinheiro, que atingem mais os clientes da Companhia, roubo de automóvel e motos dos carregadores. Mas, o que mais nos chama a atenção são as apreensões, realizadas pela Polícia Federal, de caminhões que chegam ao Terminal da CEAGESP ${ }^{271}$ com drogas e cigarros contrabandeados. A Companhia é ponto da rota do tráfico de drogas, e assim, vão se compondo os múltiplos territórios nessa parte da metrópole. Consolida-se o território dos

\footnotetext{
${ }^{270} C f$. Folha de São Paulo, 18.11.2001

271 Em novembro de 2002, a imprensa televisiva, "Jornal Nacional" noticiou que a polícia apreendeu um caminhão cheio de cigarros, comercializando de forma clandestina.
} 
traficantes nessa multiplicidade metropolitana. Estilhaços aparecem, ferindo e cortando as relações de conterrâneidade.

Existem muitos homens foragidos da polícia que trabalham prestando serviço informal, pois nesses casos não precisam apresentar atestado de antecedentes criminais para circular. Os matadores de aluguel presentes na CEAGESP tem nos chamado à atenção, nas histórias do Centro de Abastecimento. A imprensa escrita afirma que a atividade possui até propaganda nos arredores do Entreposto. A divulgação do serviço chega a ser feita com cartão de visitas; o profissional se apresenta com o cargo de "investigador". ${ }^{272}$ Segundo os dados da Segurança Pública ${ }^{273}$, nos anos de 2004 e 2005 foram registradas 17 ocorrências de homicídios por ano na Vila Leopoldina, mais precisamente na região do Terminal. ${ }^{274}$

Segundo conversa com os carregadores, é muito comum aparecer um homem morto nesses $700 \mathrm{mil} \mathrm{m}^{2}$. Existe esse temor, que ronda a vida desses trabalhadores e que aparece constantemente nas entrevistas. A violência que toma a pauta da imprensa brasileira também está no Terminal, território de conflito e concorrência. Vejamos o depoimento de Sérgio José da Silva, delegado titular do $91^{\circ}$ Distrito:

Os 30 mil caminhões que chegam todos os dias à CEAGESP trazem pessoas das mais diferentes formações, familiares, morais e educacionais. Não se resolve uma situação dessas com balas e cacetetes. É preciso se falar em educação e em assistencialismo sério, algo capaz de recuperar o homem, dando-lhe formação." (Sérgio, fevereiro de 2006)

Nas entrevistas aparece o fruto da motivação das mortes, como o problema do alcoolismo, dos bares, jogos. Vejamos um dos depoimentos:

Mais escondido, por trás das caixarias. (Bozó)”... “Aqui no Abacaxi, ali tem
gente. Pra cá do barracão, nos caminhões que embala manga, essas coisas,
tráfico maior é cocaína."... "Essas coisas que ocorreu um dia aí, não tem
nada a ver com carregador. Isso aí é rifeiro, cara que faz jogo de rifa,
outros é caixeiro, compra caixa, aí...”[...] “Mataram um...o sócio dele
apareceu morto, aí os caras desconfiaram que era ele...os Piauí, não brinca
não, os caras vieram e quebraram ele também.”[...]”Lindomar apareceu
morto, aí todo mundo desconfiado que era o sócio dele, aí mataram, aí no
outro dia, mataram o rapaz. Foi dois. Morreu um dia e o outro mataram aí
no portão. Aí uns vinte dias atrás mataram outro, aqui no portão, mataram
outro. Esse é caixeiro. Esse compra caixa vazia. Chega o feirante doa caixas
vazias, ele compra e passa pra nós que precisa,... prá embalar abacaxi. Ele
compra as caixas pequenininha que vêm com manga. Os caras compra tudo,
vende tudo [...]. O cara tudo bem de vida; o cara começa, meio valente,

${ }^{272}$ Folha de São Paulo, 18 de novembro de 2001

${ }^{273}$ Fonte: Jornal da Gente, 4 a 10 de fevereiro de 2006.

${ }^{274}$ Esse quadro permaneceu durante o ano 2006 e já houve um assassinato em janeiro de 2007. Acompanhamos os últimos assassinatos envolvendo migrantes piauienses que trabalhavam com atividades clandestinas no Terminal. 
gostava de briga, mesmo, valentão...foi dia de sábado, também, era do Piauí. (Carregador- R.)

Malaquias (1995), estudou a presença de "justiceiros" na favela Heliópolis, considerando essa atividade como parte de uma "economia submersa", ilegal. Considera que o crime organizado funciona como um "Estado Paralelo", pois não se enquadra nos parâmetros legais da sociedade, tem regras próprias de ação e desafia o sistema dentro do sistema. Alguns nordestinos relatam que alguns matadores que freqüentam a área da CEAGESP são oriundos da favela Heliópolis, aproximando a informação dos estudos do autor acima.

A solidariedade e a competição permeiam as relações entre os carregadores no processo de modernização que se instala na CEAGESP. Ao mesmo tempo em que o gesto de dividir um marmitex indica uma forma de união para sobreviver em períodos de menores rendimentos, há uma situação de competição entre os carregadores presentes em pequenos conflitos diários. Esses conflitos somente não são maiores porque acabam sendo reduzidos pelo medo que se instala diante dos matadores de aluguel presentes na área do Terminal. A série de assassinatos pode ser um indicador desses conflitos, já que no âmbito da circulação das mercadorias são constantes os desentendimentos. Vejamos um relato de depoente:

Aqui agente não sabe se volta vivo. Aqui cada um passa pela gente é uma natureza. Eu discuto, bato boca com carregador. Eles querem obrigar a gente fazer uma coisa que você não pode fazer. Aqui no galpão, lá nas flores, às vezes, quer botar você pra carregar correndo, o outro carregador, e eu não gosto de correr... (J.)

Os desentendimentos e as quebras de acordo podem ocorrer entre carregador e carregador, entre permissionário e carregador, entre carregador e feirante ou outro comprador, em um espaço onde prevalece o negócio, ou melhor, a lógica do Capital.

Existe um projeto para construir uma Grande Portaria, com câmeras, em que todos têm que se identificar, possibilitando assim um maior controle da circulação de pessoas. Esse projeto levou muito tempo para ser aprovado, publicado no diário oficial e esperando orçamento ser liberado. Entre a iniciativa de colocar o portão e a sua implantação de fato existe toda uma máquina burocrática que faz com que o projeto leve anos para ser executado $^{275}$. Esse é o tempo do poder público para as intervenções necessárias para ordenar o espaço, amarrado por uma gigantesca máquina burocrática. Vemos esse processo ocorrer em uma micro-escala do Terminal de Abastecimento gerenciado pelo Estado.

\footnotetext{
${ }^{275}$ Em novembro de 2004 o Jornal Entreposto publica a seguinte matéria -"Em 2005, CEAGESP terá portaria eletrônica". Esse fato gera uma expectativa que aparece em nossas entrevistas. Até o fechamento dessa pesquisa, em abril de 2007, não havia sinais da implantação desse Portão.
} 


\subsection{O Território e a multiterritorialidade no Terminal da CEAGESP}

A multiterritorialidade está presente no Terminal de Abastecimento. Vejamos como essa diversidade de territórios se superpõem nesse pedaço da metrópole e como se dão os mecanismos que a materializa e a torna visível.

No plano do território político e econômico encontramos esta Central de Abastecimento administrada pelo Estado, em diferentes épocas e diferentes níveis do poder público - foi gerido pelo poder estadual, e atualmente está sob a custódia do Governo Federal.

O Estado exerce o controle de entrada e saída das mercadorias a partir das notas fiscais, aloca os espaços para os atacadistas e outras atividades comerciais e de serviços, gerencia a segurança, a limpeza e a conservação do patrimônio. O Estado controla o cadastro do carregador, mediado pelo Sindicato, e, também, o cadastro dos outros ambulantes. Nessa forma de triagem delimita-se a fronteira de quem pode ser, legalmente, carregador ou ambulante, assim como a normatização das formas de execução desses trabalhos. Portanto, estar atento às políticas de transferência e modernização do Entreposto, diz respeito a observar a territorialidade que o Estado e o Capital exercem, estabelecendo uma relação de poder e espaço, no Terminal.

Não devemos nos esquecer das diversas políticas públicas promovidas pelo Estado que mobilizaram o nordestino para São Paulo, estimulando a inserção desses, inclusive de forma indireta, na Central de Abastecimento. Processo esse, em que o Estado, para a ampliação do Capital, controla a mobilidade do trabalho.

No que se refere aos territórios de grupos regionais ou culturais, encontramos uma significativa rede social de piauienses, que a partir dos laços da conterrâneidade delimitaram o espaço de trabalho e residência. Para tal processo, o Sindicato contribui, reforçando-a, quando junto com o Estado faz a triagem desses trabalhadores, manifestando assim uma coesão da rede social. Esse grupo étnico deixa a sua marca ou forma de expressão, como as Casas do Norte, localizadas no Terminal. No repertório musical que algumas vezes escutamos quando caminhamos por esse espaço, no linguajar, e em manifestações esporádicas e subliminares, que os diferenciam dos outros trabalhadores.

A circulação das mercadorias e o comércio de diferentes produtos alimentícios também compõem um território próprio para cada tipo de produto, interligando os produtos até o consumidor final. O 'nó' dessa conexão acontece no Terminal de Abastecimento. Assim, do mesmo modo, a circulação dos negócios lícitos, dos negócios ilícitos, dos jogos, da 
prostituição, das drogas e dos matadores de aluguel compõem o seu território. Esses podem estar relacionados ou não, pois cada negócio pode ter a sua própria territorialidade ou formar um único território de difícil mapeamento. Assim estão os múltiplos territórios que se sobrepõem e se entrelaçam no 'nó' 276 do Terminal de Abastecimento. Esses territórios possuem escalas diversas e envolvem questões econômicas, políticas, étnicas e relacionais de formas e intensidades diferenciadas. No entanto, mantêm a sua coexistência. Essa coexistência é comum nos espaços metropolitanos em que as territorialidades são contínuas ou descontínuas e superpõem-se. Fenômeno que ao nosso ver, é fruto do processo de modernização.

Se esse território, no Terminal, existe para alguns, os cadastrados, a desterritorialização está presente para outros, os clandestinos, na competição por trabalho estimulada pelo processo de modernização e flexibilização do trabalho.

Em sua obra $O$ mito da desterritorialidade, Rogério Haesbaert (2004) dialoga com diferentes autores (antropólogos, sociólogos, geógrafos e filósofos) sobre a questão da territorialidade, com o propósito de desmistificar o conceito da desterritorialidade como sinônimo de fim dos territórios, ou melhor dizendo, como a negação do espaço e, portanto, como um obstáculo ao desenvolvimento humano. A desterritorialização está associada a territorialização, pois formam um único processo. - “...a desterritorialização é simplesmente a outra face, sempre ambivalente, da construção do território"277. Essa ambivalência não é contradição, mas significa o múltiplo, ou melhor a multiterritorialidade em um processo de movimento.

Nossa pesquisa procura enfatizar o caráter relacional que as redes sociais promovem, atuando como um tipo de controle, que tem o seu movimento próprio em que a territorialidade é dinâmica, resultado da interação de outros territórios coexistentes no mesmo espaço. Rogério Haesbaert discute a interação da rede e do território, trazendo o conceito de territóriorede, para ir além da dicotomização e de outras visões duais, pois a rede é elemento constituinte do território

Do ponto de vista do migrante, indivíduo, na metrópole, HAESBAERT(2004:350) faz a seguinte reflexão:

Nunca é demais lembrar o pressuposto básico de que o território tratado no sentido relacional, com que trabalhamos, não é simplesmente uma coisa que se possui ou uma forma que se constrói, é mas sobretudo uma relação social mediada e moldada na/pela materialidade do espaço. Assim, mais importante

\footnotetext{
${ }^{276}$ Conceito de nó: DEMATTEIS (ver a dissertação)

${ }^{277}$ Id. p.365
} 
do que as formas concretas que construímos são as relações com as quais nós significamos e "funcionalizamos" o espaço, ainda que num nível mais individual.

Essa abordagem, que parte do indivíduo, permite entendê-lo compondo a rede social em que este está agregado; ele mobiliza os recursos relacionais para se inserir e se integrar nos diferentes circuitos urbanos, inclusive os existentes no Terminal de Abastecimento. De tal modo, identificamos a importância das redes de relações, como recurso espacial, especialmente no campo dos negócios. ${ }^{278}$ Vejamos o que diz o autor:

De alguma forma, territorializar-se, hoje, implica a ação de controlar fluxos, de estabelecer e comandar redes. Como vimos, elas jamais são completamente des materializadas, estão sempre, de uma forma ou de outra, desenhando materialmente territórios, novos territórios com uma carga muito maior de imaterialidade, é verdade, mas nem por isso "não-territoriais". As referências espaciais se difundem por todo canto, e o espaço/território é assim dotado de uma carga simbólica inédita, criando-se e recriando-se imagens muitas vezes na própria velocidade e volatilidade impostas pela lógica do mercado.(HAESBAERT, 2004:301)

A prática sindical da categoria dos carregadores acaba expressando a materialidade em determinar o seu território de trabalho quando negocia a delimitação da sua atividade na área interna do Terminal, barrando a entrada de chapas, delimitando a atividade dos funcionários na área das plataformas, pedindo maior fiscalização contra os clandestinos, em uma tentativa de preservar essa tarefa, condenada pelo processo de modernização do mercado e da circulação da mercadoria.

O autor aborda o estudo da territorialidade em uma perspectiva mais integradora do espaço geográfico, enfatizando o aspecto temporal, dinâmico e em rede que o território também assume, e onde a "integração" de suas múltiplas dimensões é vista através das relações conjuntas de dominação e apropriação, ou seja, de relações de poder em sentido amplo ${ }^{279}$ Esse processo pode ter diferentes escalas e dimensões - “...experiência integrada" (nunca total) muito mais na forma de territórios-rede, descontínuos, móveis e espacialmente fragmentados." (HAESBAERT, 2004:341).

Os múltiplos tipos de territórios se sobrepõem ou se imbricam resultando a "multiterritorialização", isso significa "a possibilidade de acessar ou conectar diversos territórios, o que pode se dar tanto através de um 'mobilidade concreta', no sentido do deslocamento físico, quanto virtual, no sentido de acionar diferentes territorialidades mesmo

\footnotetext{
278 Op. cit 359

${ }^{279}$ Id Ibdem p.340, em que baseia-se em Deleuze e Guatari
} 
sem deslocamento físico,..." ${ }^{280}$ Dessa maneira ocorre com o poder da informação que circula entre os piauienses carregadores, que tanto pode estimular a migração como estancá-la. Essa rede social articula sua territorialidade entre o Piauí e São Paulo por diversas vias: através dos recursos financeiros que são empregados no Piauí, do poder da informação que circula entre a área de origem e a área do Terminal, ou mesmo da sua área de residência, com maior densidade no município de Osasco. Essas redes informacionais possibilitam um jogo territorial original, onde existe a potencialidade, a todo instante, de recombinar territórios em uma nova multiterritorialidade ${ }^{281}$, gerando o movimento e metamorfose desses espaços.

O Estado chegou ao seu limite de ação. Os problemas estruturais que atingem a massa de desempregados da metrópole da Grande São Paulo ultrapassam as fronteiras de ação do Terminal e penetram nessa área, que é também um mercado de trabalho. Esse exército de desempregados enfrenta os fiscais e todo aparelho de cadastramento, meios de "regular", ou melhor mediar as relações nesse espaço que materializa as contradições do Capital.

No entanto, o descompasso entre o tempo lento da máquina do Estado em poder agir e intervir no processo, e o tempo veloz que age a modernização, resultam no cenário descrito, observado nos interstícios do Terminal.

Um dos exemplos da manifestação desses processos ocorre no Projeto do Portão, emblemático em nossa pesquisa. Aliás, os muros e portões são elementos representativos do tempo da modernização, nas escalas globais e também em pequenas escalas, pois a busca do controle do acesso e a regulamentação dos deslocamentos são saídas emergenciais encontradas para conter a violência crescente.

\footnotetext{
${ }^{280}$ Op. cit 344

${ }^{281}$ Op. cit. 348.
} 


\section{CONSIDERAÇÕES FINAIS}

O objeto dessa pesquisa foi estudar a mobilidade do trabalho, tendo como empírico o trabalho dos carregadores da CEAGESP, ofício assumido por migrantes nordestinos, vinculados a uma rede social de piauienses. Por meio desse trabalho no Centro de Abastecimento um grupo de migrantes nordestinos se insere na economia urbana da metrópole paulistana.

O percurso da pesquisa iniciou-se com a preocupação de identificar a presença maciça dos nordestinos na Região Metropolitana de São Paulo. Esse processo de mobilidade do trabalho no território nacional foi estudado à luz do desenvolvimento desigual e combinado entre o Nordeste e o Centro-Sul do Brasil, pois a complementaridade entre estas regiões possibilitou a reprodução do capital.

O Nordeste, em um determinado período da formação do território brasileiro, especializou-se em fornecer a força de trabalho para o Centro-Sul, que, por sua vez, absorvia essa mão de obra, em função de seu desenvolvimento econômico. Esse descompasso entre o desenvolvimento econômico dessas regiões e a mobilidade desses trabalhadores foram reforçados por políticas públicas de toda ordem, gerando uma grande corrente de migrantes nordestinos que se dirigiram para São Paulo.

A historiografia reconstitui essa corrente desde o período do Império, em que são registrados subsídios governamentais que estimularam a presença secundária de nordestinos trabalhando nas fazendas de café, simultânea á presença dos migrantes estrangeiros. Em outro momento, após os anos 30, quando não interessa mais a inserção da mão de obra importada da Europa e da Ásia, novas políticas públicas reorientam e estimulam a migração interna. Com ênfase política e um novo padrão de acumulação de capital, o governo Getúlio Vargas institui cotas para o trabalho na indústria e, assim, restringe a migração externa.

O Nordeste brasileiro sofria com uma estrutura fundiária que concentrava terras nas mãos das oligarquias regionais. Nesse quadro, a política migratória vinha para desarticular possíveis movimentos de resistência. Nos períodos de seca, esses fluxos de nordestinos se intensificavam para São Paulo, pois as políticas públicas fortaleciam a "indústria da seca".

A teoria da mobilidade do trabalho de GAUDEMAR (1977) auxiliou-nos na compreensão da presença dos nordestinos em São Paulo, pois seu foco está na produção e circulação da força de trabalho. O capital desloca uma quantidade de trabalhadores, não só 
espacialmente, como também setorialmente e socialmente. Assim, a ampliação do capital deslocou os nordestinos de sua área de origem para o centro econômico do país - São Paulo, que naquele momento exigia essa mão de obra.

Essa promoção, contava com o apoio do Estado, que criou todo um aparato para esse deslocamento, desde uma instituição que recrutava os migrantes na sua área de origem até o alojamento em São Paulo. Estrutura criada inicialmente para receber os imigrantes estrangeiros.

Os nordestinos chegavam, em um primeiro momento, pela ferrovia, e desciam na denominada Estação do Norte, no Brás. Seu primeiro contato com São Paulo constituiu nesse espaço uma nova territorialidade. Até os dias de hoje encontram-se os elementos da cultura nordestina nas ruas do Brás, o que em parte revela o processo histórico de sua inserção na cidade de São Paulo. O crescimento urbano de São Paulo está vinculado a migração, atraída, antes de mais nada, pelo processo de industrialização daquele período, principalmente após as décadas de 30 e 40, quando se inicia o processo de metropolização. ${ }^{282}$

A migração de nordestinos para São Paulo se intensificava cada vez mais e os deslocamentos, antes feitos por ferrovia, passam a ser realizados pelas rodovias, em caminhões denominados "pau-de-arara", substituídos, posteriormente, por ônibus. Esses migrantes foram ocupando outros espaços da cidade e da metrópole. Nesse processo, identificamos uma reterritorialização, marcada por elos de identidade cultural como festas, bares, culinária, comércio, moradia, trabalho e outros espaços de encontro e lazer.

Encontramos uma diversidade de pesquisas sobre a presença nordestina em São Paulo, que traçam um perfil desse migrante. Ele é geralmente pouco escolarizado, ocupa as formas de trabalho mais precarizadas, bem como, reside nos espaços mais desvalorizados; também encontra uma diversidade de obstáculos para a sua inserção, sofrendo discriminações, sendo alvo de chacotas por parte dos paulistanos.

Atualmente, eles compõem o maior grupo de migrantes na Cidade de São Paulo, assim como na Região Metropolitana de São Paulo $(72,8 \%)^{283}$. São Paulo ainda tem a maior área de concentração de nordestinos (270 mil, aproximadamente $)^{284}$, depois segue o Município de Guarulhos com um número seis vezes menor que São Paulo, e em seguida, aparecem outros municípios, que têm suas áreas urbanas conurbadas. Estes receberam, conforme dados do

\footnotetext{
${ }^{282}$ Langenbuch (1971) e Villaça (1978)

${ }^{283}$ SEADE (2003)

${ }^{284}$ Considerando migrantes que estão na cidade a partir de 1991.
} 
último censo, entre 1991 e 2000, um grupo de nordestinos doze vezes menor do que número de migrantes que se inseriu na Capital.

Podemos reunir esses municípios da Grande São Paulo em três grupos distintos - o primeiro seria Guarulhos e Itaquacetuba, o segundo a região do $\mathrm{ABC}$ e o terceiro o eixo de Osasco, Carapicuíba e Barueri. Esse último nos interessou mais de perto, por ser o principal local de residência dos carregadores da CEAGESP, em especial os piauienses, comunidade que se destaca no município de Osasco.

Dados do IBGE registram o predomínio de uma migração de retorno, portanto, há uma inversão desse fluxo migratório de nordestinos, dirigindo-se para a sua área de origem. O mesmo capital que mobilizou essa força de trabalho para o centro econômico de São Paulo provoca essa nova forma de mobilidade, que é a migração de retorno, assim como outras mobilidades, que se referem às novas formas de ocupação em trabalhos cada vez mais precárizados. É possível afirmar que a metrópole sofreu um processo de metamorfose em sua base econômica. Dois processos coexistentes podem clarear essas transformações. O primeiro diz respeito ao setor produtivo das indústrias, que foram automatizadas, liberando força de trabalho, impondo a flexibilização da mão de obra, um novo conceito para se falar da mobilidade do trabalho. O segundo é a desconcentração industrial, em que as empresas mudam suas plantas para fora da metrópole, modificando o eixo principal da migração de nordestinos, que dessa forma se dirigem para cidades do Interior do Estado de São Paulo.

Mas que ainda há um número significativo de nordestinos que migram para São Paulo, não com a mesma intensidade das décadas anteriores, o que justifica a nossa preocupação com aqueles que ainda permanecem na metrópole à busca de emprego e trabalho, mesmo que seja o mais precarizado. Selecionamos então, como objeto de estudo, os carregadores da CEAGESP, para identificar os desdobramentos do processo de flexibilização do trabalho e perceber as diferentes formas de mobilidade que se instalam e que envolvem os carregadores e outros membros da rede social de piauienses, diante do processo de modernização.

O Estudo do Terminal da CEAGESP foi importante no sentido de entender a dimensão e o significado desse mercado de trabalho na inserção dos migrantes nordestinos. Esse Terminal é o terceiro maior centro de comercialização de perecíveis do mundo e o maior da América Latina. Ocupa uma área de $700 \mathrm{mil} \mathrm{m}^{2}$ na zona oeste da cidade de São Paulo. A sua inauguração ocorreu em 1966, período de grande intensidade no fluxo de migrantes nordestinos dirigindo-se para São Paulo. O equipamento urbano da CEAGESP trouxe consigo elementos da modernização no setor de abastecimento, estimulando um maior volume de comercialização. 
Nos anos 70, esse Entreposto se caracteriza por uma maior centralidade no abastecimento, não só da metrópole, como também, do território nacional, exigindo portanto uma maior quantidade de força de trabalho. Ao longo do tempo, o Terminal sofre diversas transformações, como a mudança nos horários de funcionamento, a ampliação das edificações, a diminuição de sua centralidade e por fim, a alteração na sua gestão, que passa do governo Estadual para o Federal.

Cogitou-se nos últimos anos a sua transferência, da zona oeste da cidade para uma área mais periférica, semelhante à situação do Terminal, na década de 60, quando esse foi instalado. Hoje, ele se encontra em uma área valorizada pelo mercado imobiliário e sofre pressões por parte dos interesses deste capital imobiliário.Destacam-se nesse sentido política de privatização dessa logística de abastecimento vinculada à proposta de transferência, que representaria também uma mobilidade desse grande mercado de trabalho.

O Terminal, como mercado de trabalho, atraiu uma série de núcleos de moradias precárias, nas quais residem os migrantes, conforme mostra o mapa que elaboramos. Encontramos várias manifestações na paisagem do entorno do Terminal da CEAGESP que representam vestígios do processo da migração, e portanto, da mobilidade do trabalho. Essas manifestações de mobilidade do trabalho estão nas favelas, na presença de um grande número de moradores de rua e na instalação de um albergue nas proximidades. Desse modo, identificamos uma centralidade que o Terminal exerce sobre essa população que vê nessa área uma possibilidade de obter alimentos e trabalho, mesmo que esse seja precarizado. Uma grande parcela dessas pessoas aproveita os rejeitos para criar novas formas de ocupação, como a construção de casinhas de cachorro, reutilização das caixas, ou mesmo a comercialização das sobras de alimentos ou o uso deles para seu próprio consumo, barateando a sua forma de reprodução.

No espaço interno do mercado de trabalho do Terminal estima-se um número de 15 mil empregos gerados. Essas formas de trabalho envolvem desde os funcionários da Companhia, os atacadistas e os seus empregados, até os carregadores e os ambulantes cadastrados pela Companhia. Deve-se lembrar que há um conjunto de negócios "paralelos" que também absorve mão-de-obra, mesmo que de forma ilícita. Desse modo, o mercado de trabalho no Terminal envolve tanto trabalhos regulamentados como também, não regulamentados.

O trabalho do carregador foi escolhido para nossos estudos, pois essa categoria de trabalhadores é composta por migrantes oriundos do Nordeste, principalmente do estado do Piauí. O carregador do Terminal da CEAGESP é uma atividade autônoma e regulada pela 
Companhia a partir de um cadastro. Esse cadastro auxiliou-nos na caracterização do grupo, pois possui informações sobre escolaridade, idade, origem, residência.

Os carregadores cadastrados apresentam uma diversidade de idades, com o mínimo de 18 anos $^{285}$. Porém, o que nos surpreendeu foi a grande quantidade de homens com mais 60 anos ainda trabalhando, o que aponta para uma condição de precarização do trabalho, pois a possibilidade de aposentadoria entre eles é muito pequena.

A escolaridade dos carregadores, em geral, é muito baixa, aparecendo alguns casos de nível de instrução muito maior que o exigido nessa atividade, o que pode ser também, um sinal do processo de precarização do trabalho.

A reflexão de Gaudemar (1977) sobre a mobilidade do trabalho permite-nos fazer uma leitura da rotina de trabalho dos carregadores, muitas vezes com longas jornadas, ultrapassando o limite de esforço físico, o que acarreta uma série de problemas de saúde. Esse esforço excessivo acontece na tentativa de ampliação dos rendimentos, pois os ganhos do trabalhador por-conta-própria depende do seu dispêndio de força física e intensidade do seu trabalho. Assim, os homens se sujeitam às exigências da ampliação do capital, disponibilizando os seus corpos a todo tipo de esforço, intensidade e ritmos. Em uma situação de afastamento por problemas de saúde, ou em outra situação que necessite da seguridade social, poucos podem usufruir desse direito, pois em geral, grande parte deles não deposita continuamente a contribuição da previdência social, pois seu pagamento representa um peso no orçamento.

Conforme o resultado das entrevistas, os rendimentos de modo geral são baixos, mas asseguram melhores ganhos do que se fossem assalariados. Além desse fator, esses carregadores apontam a sua preferência em trabalhar por conta-própria, pela autonomia em relação aos horários e pela ausência da figura do patrão.

A temática do trabalho autônomo ascende com a flexibilização do trabalho, pois é vista como uma alternativa frente à redução de empregos e à crise do trabalho. No entanto é velado o mito da autonomia, pois ao mesmo tempo em que esse trabalho nega o assalariamento, ele se submete à mobilidade forçada, expondo as faces da mobilidade do trabalho. No caso do trabalhador por-conta-própria, a mobilidade do trabalho, pode também significar a possibilidade de ascensão social, difícil na área de origem do migrante. Em alguns casos, esse projeto é bem sucedido e o migrante ascende socialmente, o carregador consegue um pecúlio

\footnotetext{
${ }^{285}$ Exigência regulamentada pela Companhia.
} 
torna-se atacadista ou obtém negócio próprio na área de origem, inserindo-se na economia urbana de seu município.

Em Marx, a figura do carregador poderia ser classificada como lumpen- proletariado, isto é, o grupo de trabalhadores mais precarizados. Essa condição fica difusa em tempos de modernização, pois o carregador regulamentado ganha legitimidade frente ao Estado e esses homens seguem a lógica do capital, como mercadorias móveis.

Ao longo do tempo, o número de carregadores foi se ampliando e alcançou o número limite de trabalhadores permitido pela Companhia para atender a demanda dessa atividade, que hoje está saturada.

A trajetória ou a história de trabalho desses homens foi marcada pelo trabalho como carregador clandestino até conseguir a sua regulamentação. No entanto, esses mesmos carregadores regulamentados se opõem à presença dos clandestinos, que se tornam concorrentes na competição por trabalho. Esse conflito é assumido pelo Sindicato, que de acordo com a Companhia, delimita as fronteiras e demarca o território dos carregadores cadastrados. Essa situação de confronto se acirra em períodos de maior desemprego na metrópole paulista.

A redução de oportunidades de trabalho como carregador na CEAGESP está vinculada a um conjunto de fatores como a reestruturação das formas de circulação dos alimentos, a modernização da Companhia e o aumento excessivo no número de carregadores, mesmo como clandestinos.

A reestruturação na circulação dos alimentos significou a redução dos números de feiras-livres, como uma conseqüência da inserção dos supermercados no setor hortifrutigranjeiros. Como os feirantes são os principais clientes do carregador no Terminal da CEAGESP, isso ocasionou uma grande dispensa desse trabalhador . Acentuada, ainda, pela redução da centralidade do Terminal frente à abertura de outros CEASAS e pelas mudanças na circulação dos hortifrutigranjeiros, já que parte do produto não passa mais pelo Terminal.

A modernização da Companhia, representada pela implantação de empilhadeiras e pallets, mesmo restrita ao setor das frutas, seguindo a lógica do desenvolvimento tecnológico para a ampliação do capital e reduzindo a necessidade da força de trabalho, passa ser uma ameaça ao trabalho do carregador. A idéia da qualificação do carregador, que vê sua atividade se reduzindo, surge como um problema. A questão é: se a qualificação do carregador para outra forma de trabalho, que exija um número menor de pessoas, e não vai absorver assim, toda a categoria, resolverá a situação dos sobrantes? O tempo da implantação tecnológica é muito mais veloz que o tempo da qualificação, apontando para a redução da 
inserção desses trabalhadores, que se tornam mais móveis. Dessa maneira, a flexibilidade do trabalho analisada por ANTUNES (2000) atinge a área do Entreposto, pois muitos dos trabalhadores de outros setores da economia vão buscar no Terminal uma nova possibilidade de inserção, inicialmente como carregadores clandestinos. O carregadore clandestino, além do desempregado, também pode ser o empregado dos boxes, que por possuír salário baixíssimo, complementa a renda como carregador. Tanto o desempregado como o empregado podem ser conterrâneos, antigos ou recém-chegados, dos carregadores regulamentados, que se colocam ora em uma ação de conflito, em tempos de crise do trabalho, e ora em uma ação de solidariedade.

O carregador autônomo está inserido no circuito da economia urbana, mais especificamente no circuito inferior, classificação elaborada por Milton Santos (1979). Pois essa atividade reúne características que assim a definem, como pequeno capital, uso de tecnologia simples, baixa escolaridade e seus ganhos dependem do dispêndio de sua força de trabalho. Essa baixa exigência do circuito inferior faz com esse absorva mais o migrante, facilitando a sua inserção. Mesmo assim, essas atividades do circuito inferior também chegam ao seu nível de saturação, sendo necessário que esses trabalhadores realizem uma nova mobilidade; que, Gaudemar e Milton Santos, identificam como uma plasticidade. Esse esgarçamento mobiliza-os cada vez mais para um trabalho precarizado, sempre empurrando esses homens para o trabalho por-conta-própria, transformando o "subemprego" no mito do empreendedorismo.

A concentração de piauienses mereceu um estudo do comportamento da rede social sob o capital, como um mecanismo de inserção em uma determinada ocupação. Desse modo, a rede social demarcou um território nordestino de trabalho no Terminal da CEAGESP. Os símbolos que permeiam a cultura nordestina foram aparecendo ao longo da pesquisa, como a figura de Santa Luzia na Missa dos Carregadores, as Casas do Norte, instaladas na área interna do Terminal, o carregador repentista e a imagem do Frei Damião na parede do Sindicato. Esses elementos são evidências visíveis da presença nordestina, ganham materialidade e demarcam o seu território, controlado principalmente pelos piauienses.

Essa grande rede social de piauienses foi o suporte de entrada de muitos migrantes que trabalham no Terminal da CEAGESP. A informação sobre a possibilidade de trabalho em São Paulo era veiculada na área de origem pelos migrantes já inseridos; portanto, esses se tornaram a primeira referência para aqueles que aspiravam migrar. As relações de parentesco, vizinhança e conterraneidade eram as pontes para viabilizar a mobilidade, isto é, se tornaram um recurso de relações para alçar o mercado de trabalho. As informações sobre como 
ingressar no Terminal são um patrimônio que o recém chegado adquire do conterrâneo já inserido. No entanto, a modernização tem reduzido a força da conterraneidade, no momento em que as oportunidades de trabalho como carregador se restringem. Além de acirrar a competitividade, fortalece-se a territorialidade para impedir a presença de outros concorrentes. Esse processo foi identificado na forma de recrutamento, em acordo entre a Companhia e o Sindicato. Em uma situação de disputa para a inserção do carregador regulamentado, prevalece a força da rede social, independentemente dos atributos pessoais.

As redes sociais são constituídas por vínculos de confiança e de contrapartidas. Vemos esse processo em situações em que o antigo carregador cadastrado insere seu conterrâneo, "contratando-o" ou "dividindo trabalho", enquanto esse espera a condição de regulamentado. O mesmo ocorre em relação aos auxílios para adquirir o carrinho ou os primeiros recursos para pagar as taxas necessárias para o cadastramento.

A rede de piauienses transbordou a categoria de carregadores, e hoje, parte desses migrantes se ocupa como atacadistas nos boxes das frutas e legumes. Os migrantes mais recentes se tornaram empregados nos boxes, pois a atividade de carregador cadastrado está cada vez mais restrita. Encontram-se piauienses também nas atividades das caixarias e como ambulantes.

A atividade do carregador é considerada e assumida como uma ocupação masculina, devido às exigências do esforço físico necessário na execução da tarefa. As mulheres da rede social se inseriram na atividade de servir cafés. Como ambulantes cadastrados, sofrem com processos semelhantes aos dos carregadores, combatendo as cafezeiras clandestinas. Essas, por estarem em situação de clandestinidade, sofrem constrangimentos de toda ordem em um ambiente masculinizado.

Os carregadores piauienses que trabalham no Terminal residem em grande parte no Município de Osasco, seguido de Carapicuíba, Barueri e proximidades. A rede ferroviária e as linhas de ônibus interurbanos reforçam essa conexão entre a moradia e o trabalho. Nesse sentido, a rede social se materializa, não só no trabalho mas também no local de residência.

Em períodos de alta temporada, no verão, ocorre uma outra forma de mobilidade do trabalho: a migração temporária ou trabalho temporário. Em décadas passadas, no Terminal, essa migração já foi mais intensa; hoje está em declínio e restrita a um grupo menor de migrantes que realizam anualmente o vai e vêm entre o Piauí e São Paulo. São funcionários públicos, trabalhadores urbanos e lavradores, que vêm para São Paulo garantir um rendimento suficiente para aplicar na área de origem. Assim que conseguem o pecúlio almejado para abrir ou melhorar o negócio próprio, eles deixam de realizar a migração, mesmo porque, essa 
migração está sendo menos requerida pelo mercado de trabalho no Terminal, devido às transformações na circulação dos hortifrutigranjeiros, uma vez os produtos passam pelo Centro de Abastecimento em menor escala.

Uma pequena parcela dos carregadores do Terminal, diante do declínio da atividade, não passa incólume à migração de retorno; no entanto, os dados apontam apenas $1 \%$ (um por cento) de desistência. A maior parcela continua na atividade mesmo com a redução de oportunidades.

Existe ainda uma face oculta no Terminal, que são os negócios ilícitos, como prostituição, roubo, jogos e assassinatos. Esses elementos sinalizam o processo de fragmentação instalado nesse mercado de trabalho.

A solidariedade e a competição perpassam pelas relações dos carregadores sob o processo de modernização, instalado no Terminal da CEAGESP. Os conflitos nesse campo de negócios ganham materialidade na série de assassinatos que ocorrem no Centro de Abastecimento, gerando um grande temor entre os carregadores e toda comunidade que ali convive.

Encontra-se no Terminal da CEAGESP a manifestação da multiterritorialidade. Vejamos: os territórios políticos e econômicos, nos quais o gerenciamento da área é responsabilidade do Estado e as atividades econômicas lícitas estão sob responsabilidade do setor privado; os territórios de grupos regionais ou culturais, nos quais a grande rede social de piauienses predomina entre os carregadores e delimita o seu campo de trabalho; e outros territórios, como o dos negócios ilícitos que à sua maneira exercem o seu poder. Esses territórios se imbricam, possuem escalas diversas e envolvem questões econômicas, políticas, étnicas, culturais e relacionais, com intensidades e formas diferenciadas, mas que coexistem. Portanto, observando a dinâmica que se estabelece no Terminal da CEAGESP, identificamos como o processo de modernização instala uma multiplicidade de territórios, próprio do espaço metropolitano.

Apontamos ao fim de nossos estudos alguns problemas e temas para futuras investigações, que perpassaram por nossa pesquisa, que merecem um olhar mais atento do que o nosso objeto de estudo permitia avançar.

A pesquisa que desenvolvemos tangenciou outros assunto que poderá ser desenvolvidoe que poderá ser aprofundado em futuras pesquisas como acompanhar o conflito sobre a presença de atividade de produção e ou reaproveitamento das caixas do Entreposto, as Caixarias, que ocupam uma área em plena valorização imobiliária, sofrendo todo tipo de 
pressão do capital imobiliário para alterar o lugar dessa atividade e, conjuntamente, da população que a pratica.

Merece, também, um estudo próprio as transformações na circulação da mercadoria alimentos e no abastecimento da metrópole, reestruturando e criando elos, possuem uma dinâmica veloz, particular e complexa que merece, também, um estudo próprio.

Ao fim da pesquisa conseguimos avançar nos dados sobre a ocupação dos carregadores piauienses no Município de Osasco, identificando locais que apresentavam maior concentração dessa categoria. A próxima questão que emerge é entender como se dá o comportamento da rede social de piauienses em seu local de moradia e tentar explicar a distribuição dos piauienses no município de Osasco. Será que o Terminal da CEAGESP foi a primeira referência dos piauienses que moram em Osasco ou existem outros mercados de trabalho através dos quais eles consolidaram sua rede social?

Para Finalizar, registramos o fato de encontrarmos uma grande quantidade de migrantes com idade avançada trabalhando no Terminal, assim como o fato das assistentes sociais declararem que o albergue localizado em seu entorno abriga um número expressivo de moradores de rua com mais de sessenta anos, conduziu-nos à preocupação com a permanência desses migrantes na metrópole e as condições dadas para o seu envelhecimento. Identificamos na pesquisa que poucos migrantes contribuem para a previdência social, pois essa contribuição acaba sendo um peso em seu orçamento. Esse dado reiterou a nossa preocupação: o capital mobilizou levas de nordestinos para a metrópole da Grande São Paulo, nas décadas em que esse pólo absorvia essa mão de obra, e hoje, esse mesmo pólo apresenta índices elevados de desemprego, sendo que uma parte desses migrantes está sem qualquer tipo de benefício para essa fase da vida, na qual já não pode vender a sua força de trabalho. Ao Estado resta construir cada vez mais albergues para esses migrantes que estão envelhecendo na cidade, já que a previdência social também chega ao seu limite de ação. Esse migrante está ocupando os albergues, como estoques que não podem ser mais comercializados, pois são mercadorias em desuso. 


\section{BIBLIOGRAFIA}

ABREU, Adilson de Avanci. "As funções urbanas da zona do Mercado Central de São Paulo”. In: Geografia Econômica 2. São Paulo: Instituto de Pesquisas, 1966.

ALBERTI, Verena. “A Entrevista.” In: História oral: a experiência do CPDOC. Rio de Janeiro: FGV, 1990. pp.45-100.

ALBUQUERQUE Jr., Durval Muniz. "Paraíbas e baianos: órfãos do campo filhos legítimos da cidade”. In: Travessia, n.8. São Paulo: Centro de Estudos Migratórios, set./dez. de 1990. pp. 27-32.

ALVES, Vicente Eudes Lemos. Formação territorial sul piauiense: modernização agropecuária e resistência camponesa. São Paulo: USP, 2000.

ANDRADE, Margarida Maria de. "Brás, Moóca e Belenzinho - 'bairros italianos' na São Paulo além-Tamanduatê̂’. Revista do Departamento de Geografia, v.8. São Paulo: FFLCH/ USP, 1994. pp.97-102.

ANGELO, Assis. "A presença dos cordelistas e cantadores repentistas em São Paulo". In: Cidade. Ano 2. São Paulo: Departamento do Patrimônio Histórico, 1995.

A presença dos cordelistas e cantadores repentistas em São Paulo. São Paulo: IBRASA, 1996. $123 \mathrm{p}$.

ANTUNES, Ricardo. Os sentidos do trabalho. 3 ed. São Paulo: Boitempo, 2000.

. Adeus ao trabalho. 7 ed. São Paulo: Cortez, [1995] 2003.

AYALA, Maria Ignez. No arranco do grito (aspectos da cantoria nordestina). Tese de Doutorado. São Paulo: FFLCH/ USP, 1982.

AZEVEDO, M. M. M.; BAPTISTA, D. M. T.; VIDAL, M. S. C. "CTN - um Nordeste paulistano.” In: Travessia. n.34. São Paulo: Centro de Estudos Migratórios, mai./ago. de 1999. pp.39- 42.

AZEVEDO, Mirandulina. Migração e memória: a experiência dos nordestinos. Tese de Doutorado. São Paulo: Departamento de Geografia da FFLCH/ USP, 2002. 234 p.

BAPTISTA, Dulce M. T. Nas terras do "Deus Dará": nordestinos e suas redes sociais em São Paulo. Tese de Doutorado. São Paulo. Ciências Sociais/ PUC-SP, 1998. 324 p.

BAENINGER, Rosana. "Região, metrópole e interior: espaços ganhadores e espaços perdedores nas migrações recentes no Brasil, 1980-1996”. In: NEPO. n.35. Campinas: Unicamp, 2000. 
BARROS, N. C. "Migrações, urbanização e setor informal: estudo sobre as formas de comercialização em área de emigração para as metrópoles de São Paulo e Rio de Janeiro”. In: Boletim Paulista de Geografia. São Paulo: AGB, 1988. p.105-112.

BERMAN, Marshall. Tudo que é sólido desmancha no ar; aventura da Modernidade. São Paulo: Companhia de Letras, 1987. 347 p.

BRENNAN, Georeanne. France. Saveurs \& Traditions. Paris: Maxi Livre, 2004.

BISON, Wanderluce Pessoa. A volta por cima - mulheres migrantes entre o Vale do Jequitinhonha e São Paulo. Dissertação de Mestrado. Departamento de Geografia da FFLCH, USP, 1995. 78 p.

BOSCO, Santa Helena; JORDÃO NETO, Antônio. Migrações: estudo especial sobre as migrações internas para o estado de São Paulo e seus efeitos. São Paulo, Secretaria da Agricultura do Estado de São Paulo, 1967. pp.1-40.

CACCIAMALI, Maria Cristina. Setor informal urbano e formas de participação da produção. São Paulo: IPE/ USP, 1983.

CAPEL, Horácio. Filosofia y Ciencia en la Geografia Contemporânea. Barcelona: Barcanova, 1981.

CARLOS, Ana Fani Alessandri. A cidade. 2 ed. São Paulo: Contexto, 1994. 98 p.

CEAGESP, Relatório da Diretoria. São Paulo, [impresso]1970.

CEM (Centro de Estudos Migratórios). Migrações no Brasil. São Paulo: Paulinas, 1980. 82 p. . Nordestinos. Cadernos de migração. v.2. São Paulo: CEM/ USP, 1988. 38 p.

CENTRO DE QUALIDADE EM HORTICULTURA. Perfil do comprador de frutas $e$ hortaliças frescas no Entreposto Terminal de São Paulo, Ceagesp, 2005.

CEPRO (Fundação Centro de Pesquisas Econômicas e Sociais do Piauí). Atlas da exclusão social no Piauí. Teresina: CEPRO/PI, 2003.

COSTA, Haesbaert Rogério. Gaúchos no Nordeste; modernidade, desterritorialização e identidade. Tese de Doutorado. São Paulo: Departamento de Geografia da FFLCH/ USP, 1995

CUNHA, José Marcos. "Expansão metropolitana na transição migratória - o papel dos subcentros regionais”. In: SP em Perspectiva. São Paulo: SEADE, 1995.

DAMIANI, Amélia L. “A cidade (des) ordenada”. In: Boletim paulista de Geografia. n.72. São Paulo: AGB, 1994. p.95-109.

DURHAN, Eunice. A caminho da cidade. São Paulo: Perspectiva, 1973.

ESTRELA, Ely S. Os sampauleiros do alto sertão da Bahia (cotidiano e representações). São Paulo: Humanitas/ Educ/ Fapesp, 2003. 209 p. 
EVELYN, Suzana. Cadê a festa? Dissertação de Mestrado. São Paulo: Ciências Sociais/ FFLCH/ USP, 1988.

GAETA, Antonio Carlos. "Notas introdutórias sobre comercialização de alimentos e concentração de capital”. In: Boletim paulista de Geografia. v.62. São Paulo: AGB, 1985. p.24-37.

GAUDEMAR, Jean Paul de. A mobilidade do trabalho e acumulação do capital. Lisboa: Estampa, 1977. 404 p.

GOLDENSTEIN, L. e SEABRA, M., "Divisão Territorial do trabalho e a nova Regionalização". Revista do Departamento de Geografia. São Paulo: IGEOG/USP n. 1,p.21-47,1982

GOMES, Ângela Maria de Castro. "A construção do homem novo: o trabalhador brasileiro". In: OLIVEIRA, Lúcia Lippi. Estado Novo, ideologia e poder. Rio de Janeiro: Zahar, 1982.

GOMES, Sueli de Castro. Do comércio de retalho à feira da sulanca: uma inserção do migrante em São Paulo. Dissertação de Mestrado. São Paulo: Geografia Humana/ FFLCH/ USP, 2001.

__ "Nas metamorfoses metropolitanas: o migrante na Ceagesp". In: Anais do CEPEGE; I Seminário de Pesquisa em Geografia - Pesquisa em Geografia no Século XXI. São Paulo: USP. 2003.

GONÇALVES, Paulo César. Migração e mão-de-obra; retirantes cearenses na economia cafeeira do Centro-Sul (1877-1901). Dissertação de Mestrado. São Paulo: História Econômica/ FFLCH/ USP, 2002.

GUIMARÃES, Olmária. O papel das feiras-livres no abastecimento da cidade de São Paulo. São Paulo: Instituto de Geografia/ USP, 1969.

HARVEY, David. Condição pós-moderna. Uma pesquisa sobre as origens da mudança cultural. 2 ed. São Paulo: Loyola, 1993.

HAESBAERT, Rogério. "Desterritorialização: entre as redes e os aglomerados de exclusão". In: Geografia: conceitos e temas. Rio de Janeiro: Bertrand Brasil, 1995. pp.165-205. O mito da desterritorialização. Rio de Janeiro: Bertrand Brasil, 2004.

."Migração e desterritorialização". In: Cruzando fronteiras disciplinares: um panorama dos estudos migratórios. Rio de Janeiro: Revan, 2005.

HEIDEMANN, Dieter. "Os migrantes e a crise da sociedade do trabalho: humilhação secundária, resistência e emancipação.” In: Migrações: discriminações $e$ alternativas. São Paulo: Paulinas/ SPM, 2004. 
JACQZ, Irene. Integração dos imigrantes nordestinos em São Paulo: assimilação ou não. São Paulo [mimeo], 1982.

JAKOBSEN; MARTINS; DOMBROWSKI (org.). Mapa do trabalho informal. São Paulo: CUT/ Fundação Perseu Abramo, 2000.

KOWARICK, Lúcio. A espoliação urbana. São Paulo: Paz e Terra, 1993.

KRISIS, Grupo. Manifesto contra o trabalho. Trad. Heinz Dieter Heidemann. Cadernos do Labur. São Paulo: Geousp-Labur, 1999. 90 p.

KURZ, Robert. O colapso da modernização. São Paulo: Paz e Terra, 1996 [1991]. 244 p. . Os últimos combates. São Paulo: Vozes, 1997. 391 p.

."Dominação sem sujeito". In: PAIVA, Jorge (org.). Seminário internacional: teoria crítica radical, a superação do capital e a emancipação. Fortaleza, 2000. pp.151229.

LA CORTE, Judith de. "O tomate no abastecimento da cidade de São Paulo". In: Geografia Econômica. n.3. São Paulo: Instituto de Geografia/ USP, 1966.

"Alguns aspectos do abastecimento da cidade de São Paulo em uva e figo". In: Geografia Econômica. n. 9. São Paulo: Instituto de Geografia/ USP, 1971.

. "Abastecimento da cidade de São Paulo em produtos hortifrutícolas: problemas e métodos de um estudo”. In: Boletim paulista de Geografia. n.52. São Paulo, 1976.

LANGENBUCH, J. R. A estruturação da grande São Paulo - estudo de Geografia Urbana. Rio de Janeiro: IBGE, 1971.

LEFEBVRE, Henri. A vida cotidiana no mundo moderno. São Paulo: Ática, 1991[1968].

LEGASPE, Luciano. Reciclagem: a fantasia do eco-capitalismo. Dissertação de Mestrado. São Paulo: Departamento de Geografia da FFLCH/ USP, 1996.

LENCIONI, Sandra. Reestruturação urbano-industrial: centralização do capital e desconcentração da metrópole de São Paulo - indústria têxtil. Tese de Doutorado. São Paulo: Departamento de Geografia da FFLCH/ USP, 1991.

LIMA, T. T. de. "O pequeno e o grande comércio - elementos teóricos”. In: Boletim Paulista de Geografia. n.65. São Paulo: AGB, 1987. p.121-125.

LIPIETZ, Alain. "O terciário, arborescência da acumulação capitalista: proliferação e polarização”. In: Seleção de texto. São Paulo: AGB, 1986.

MALAQUIAS, Ariovaldo. "Como nasce um justiceiro". In: Travessia. n.23. São Paulo: Centro de Estudos Migratórios, set./dez. de 1995. pp.20- 24.

MALAGUTI, Manoel Luiz. Crítica à razão informal. Vitória: Edufes; São Paulo: Boitempo, 2000. 
MARTIN, André Roberto. O bairro do Brás e a deterioração urbana. Dissertação de Mestrado. São Paulo: Departamento de Geografia da FFLCH/ USP, 1984. 187 p.

MARTINS, José de Souza. A imigração e a crise do país agrário. São Paulo: Biblioteca Pioneira de Ciências Sociais, 1973.

O cativeiro da terra. São Paulo: Ciências Humanas, 1979.

."Migrações temporárias: problema para quem?”. In: Travessia. n.1. São Paulo: CEM, 1988a. pp.5-8.

. "O vôo das andorinhas: migrações temporárias no Brasill". In: Não há terra para plantar neste verão. O cerco das terras indígenas e das terras de trabalho no renascimento político do campo. Petrópolis: Vozes, 1988b. pp.43-61.

"Migrações internas no mundo contemporâneo". In: Convivendo com o diferente. Brasília: CSEM, 1999. pp.27-36.

. “O problema das migrações no limiar do terceiro milênio". In: O fenômeno migratório no limiar do terceiro milênio. Petrópolis: Vozes, 1998. pp.19-34.

MARX, Karl. O capital: crítica da economia política. v.1. 15 ed. Rio de Janeiro: Bertrand Brasil [1867] 1996. pp.1-161.

. O dezoito de Brumário de Louis Bonaparte. São Paulo: Morais, [1852]1987.

MEDINA, Cremilda (org.). Forró na garoa. Col. São Paulo de Perfil. São Paulo: 4CJE/ ECA/ USP, 1989. $156 \mathrm{p}$.

MENEZES, Marilda. "Trabalho por conta própria: sonho dos migrantes". In: Travessia. n.8. São Paulo: CEM, 1990. pp.22-26.

. Da Paraíba pra São Paulo e de São Paulo pra Paraíba. Dissertação de Mestrado. Campina Grande: Sociologia/ UFPB, 1985. pp.1-157.

MEZGRAVIS, Pedro. Os chapas e o seu papel no meio técnico científico. Dissertação de Mestrado. Dep. de Geografia da FFLCH/ USP, São Paulo. 2006.

MIGUEZ, Eduardo. "Microhistoria, Redes Sociales e Historia de Las Migraciones: ideas sugestivas y fuentes parcas”. In Inmigracion y Redes Sociales en La Argentina Moderna. Org. María Bjerg e Hernán Otero. Tandil: CEMLA/ IEHS, 1995. pp.23-34.

MONBEIG, Pierre. Pioneiros e Fazendeiros de São Paulo. $2^{a}$ ed. São Paulo: Ed.Hucitec. Ed. Polis, 1998.

MONTEIRO, Bettina Duarte et alii. “Ambulantes de Largo 13”. In: Travessia. n.16. São Paulo: Centro de Estudos Migratórios, mai./ago. de 1993. pp.10 -13.

MUMFORD, Lewis. Perspectivas urbanas. Buenos Aires: Emecé, 1969. 
NASSER, Ana Cristina. Sair para o mundo: trabalho, família e lazer na vida dos excluídos. São Paulo: Hucitec/ Fapesp, 2001.

NAVARRO, Jurema Ricci. Estágio realizado em empresa - Ceagesp. São Paulo: Serviço Social da PUC-SP, 1992.

OLIVEIRA, Chistian D. M. de. “Terciarização e espaço metropolitano”. In: Boletim paulista de Geografia. n.65. São Paulo: AGB, 1987. pp.49-57.

OLIVEIRA, Francisco de. Elegia para uma re(li)gião. 3 ed. Rio de Janeiro: Paz e Terra, 1981. $137 \mathrm{p}$.

PAIVA, Odair da Cruz. Caminhos cruzados . Tese de Doutorado. São Paulo: Departamento de História da FFLCH/ USP, 2004.

PALMEIRA, Moacir G. Soares. Projeto emprego e mudança sócio econômica no Nordeste. Rio de Janeiro: UFRJ, 1977. 74 p.

PENNA, Maura. O que faz ser nordestino: identidades sociais, interesses e o "escândalo Erundina”. São Paulo: Cortez, 1992. pp.1-113.

PETRONE, Pasquale. "A cidade de São Paulo no século XX”. In: Revista de História. n.21 e 22. São Paulo: Brasil, jan./jun de 1955.

PINTAUDI, Silvana M. "Mudanças nas formas de comércio varejista e a implantação dos supermercados na grande São Paulo”. In: Boletim paulista de Geografia. v.66. São Paulo: AGB, 1988. pp.24-37.

PLANO DIRETOR, Diagnóstico - plano regional da Subprefeitura da Lapa, quadro situacional preliminar Lapa. [Digitalizado]. São Paulo: FUPAM, 2003.

POSTONE, Moishe. "Repensando a Crítica de Marx ao Capitalismo" in PAIVA, Jorge (Org.) Teoria Crítica Radical a Superação do Capitalismo e a Emancipação Humana. Fortaleza: Instituto de Filosofia e Práxis, 2000. p. 85 - 150.

PÓVOA NETO, Helion. "Migrações internas e mobilidade do trabalho no Brasil atual. Novos desafios para a análise”. In: Experimental. n.2, 1997. p.11-24

A produção de um estigma: Nordeste e nordestinos no Brasil”. In: Travessia. n.19. SãoPaulo: CEM, mai./ago. de 1994. pp.20-22.

PRADO Jr., Caio. A cidade de São Paulo - geografia e história. 2 ed. São Paulo: Brasiliense, $1983.93 \mathrm{p}$.

PRANDI, Reginaldo. O trabalhador por conta própria sob o capital. Col. Ensaio e Memória. São Paulo: Símbolo, 1978. 165 p.

POCHMAN, Marcio. O Trabalho sob Fogo Cruzado. São Paulo:Contexto, 2002 
O excedente de mão-de-obra no município de São Paulo. In: Mapa do Trabalho Informal. São Paulo: Perseu Abramo, CUT. 2000

QUEIROZ, Maria Isaura Pereira. 'Relatos orais: do 'indizível' ao 'dizível'. In: SIMSON, Olga Moraes (org.). Experimentos com histórias de vida. São Paulo: Vértice/ Ed. Revista dos Tribunais, 1988. pp.14-43.

RAMIRES, Francisco. Severino na metrópole . Dissertação de Mestrado. São Paulo: Ciências Sociais da FFLCH/ USP, 2001.

RAMELLA, Franco. "Por un Uso Fuerte del Concepto de Red en los Estudios Migratórios". In: Inmigracion y Redes Sociales en La Argentina Moderna. Org. María Bjerg e Hernán Otero. Tandil: CEMLA/ IEHS, 1995. pp.9-21.

RAMOS, Aluísio Wellichan. Industrialização e desindustrialização na metrópole paulistana: o caso da Água Branca. Trabalho de Graduação Individual. São Paulo: Departamento de Geografia da FFLCH/ USP, 1998.

RAVENSTEIN, E. G. "As leis da migração”. In: MOURA, Hélio A. de (org). Migração interna - textos selecionados. Tomo I. Fortaleza: BNB, 1980. p.19-88.

REALE, Ebe. Brás, Pinheiros, Jardins: três bairros, três mundos. São Paulo: Edusp, 1982.

RESENDE, Márcia Spyer. A geografia do aluno trabalhador. São Paulo: Loyola, 1986.

RIGAMONTE, Rosani Cristina. Sertanejos contemporâneos: entre a metrópole e o sertão. São Paulo: Humanitas/ FAPESP, 2001.

RODRIGUES, Arlete Moisés. Moradia nas cidades brasileiras. São Paulo: Contexto, 1991.

ROSSINI, Rosa Ester. "A Alface em São Paulo: aspectos de seu abastecimento na capital”. In: Geografia Econômica. n.8. São Paulo: Instituto de Geografia/ USP, 1971.

ROMERO, Bianca de Cássia Romero. Análise da localização de plataformas logísticas: aplicação ao caso do ETSP - Entreposto Terminal São Paulo - da Ceagesp. Dissertação de Mestrado. São Paulo: Engenharia de Sistemas Logísticos/ Escola Politécnica/ USP, 2006.

SALIM, Celso Amorim. "Migração: o fato e a controvérsia teórica". In: VIII Encontro Nacional de Estudos Populacionais. Anais, v.3. São Paulo: ABEP, 1992. pp.119-144. SANTOS, Milton. Pobreza urbana. São Paulo: Hucitec, 1979a.

_..O espaço dividido. Trad. Myrna T. R. Viana. São Paulo: Francisco Alves, 1979 b. pp.2354.

. A natureza do espaço. São Paulo: Edusp, 2002.

SANTOS, Milton e SOUZA, Maria Adélia A. (org). "Circuitos espaciais da produção: um comentário”. In: A construção do espaço: São Paulo: Nobel,, 1986. pp.121-134. 
SAYAD, Abdelmalek. A imigração ou os paradoxos da alteridade. São Paulo: Edusp, 1998. $286 \mathrm{p}$.

SEABRA, Manoel. "Abastecimento da cidade de São Paulo em gêneros alimentícios". In: Geografia Econômica. n.1. São Paulo: Instituto de Geografia/ USP, 1966a.

__. "A cooperativa Central Agrícola Sul-Brasil e o abastecimento da cidade de São Paulo". In: Geografia Econômica, n.5. São Paulo: Instituto de Geografia/ USP, $1966 b$.

SEABRA, Odette Carvalho de Lima Seabra. "Urbanização, bairro e vida de bairro". In: Travessia. n.38. São Paulo: CEM, set./dez. de 2000. pp.11-17.

"Território do uso: cotidiano e modo de vida". In: Cidades. v.1, n.2. Presidente Prudente: GEU, 2004. p.181-206.

SEADE. SP Demográfico. O estado de São Paulo continua o principal pólo dos migrantes do país. Ano 4. n.6. set. de 2006.

SECRETARIA DE ESTADO E CULTURA. Catálogo do Museu da Imigração. São Paulo:Imprensa Oficial, setembro de 1997.

SILVA, Flávia Elaine. "Urbanismo, urbanização e vida cotidiana". In: Travessia. n.47. São Paulo: CEM, set./dez. de 2003 a.

__. "Uma deriva entre urbanismo e urbanização". In: Anais do CEPEGE - I Seminário de Pesquisa em Geografia - Pesquisa em Geografia no Século XXI. São Paulo: USP, 2003 b.

_. Favela, que negócio é este? Dissertação de Mestrado. São Paulo: Departamento de Geografia da FFLCH/ USP, 2006.

SILVA, José Roberval Freire da. Migrantes de canudos em São Paulo. Dissertação de Mestrado. São Paulo: Ciências Sociais/ PUC-SP, 2000.

SILVA, Maria Aparecida de M. Errantes do fim do século. São Paulo: UNESP, 1999.

"Migrantes temporários. A face oculta do agronegócio paulista". In: Travessias na Desordem Global. São Paulo: Paulinas, 2005.

SILVA, Sidney A. da. Costurando sonhos. Trajetória de um grupo de imigrantes bolivianos em São Paulo. São Paulo: Paulinas, 1997. 292 p.

SINGER, Paul. Economia política da urbanização. 12 ed. (1973). São Paulo: Brasiliense, $1990.152 \mathrm{p}$.

Desenvolvimento econômico e evolução urbana. São Paulo: Companhia Editora Nacional, 1974.

SOBRAL, Germano Leóstenes A. "Imagens do migrante nordestino em São Paulo". In: Travessia. n.17. São Paulo: CEM, 1993. 
SOUZA, Emanuel Bandeira. Nos porões dos arrecifes; o trabalho autônomo no comércio de confecção da cidade de Recife. Dissertação de Mestrado. Recife: Sociologia da UFPE, 1984.

SOUZA, Itamar de; MEDEIROS Filho, João. Os degregados filhos da seca. Petrópolis: Vozes, 1983.

VAINER, Carlos B. "Política migratória recente no Brasil - notas para uma avaliação". In: Colóquio internacional - estrutura de emprego e dinâmica espacial da força de trabalho. Rio de Janeiro: PUR/ UFRJ, 1985. 24 p

"A Violência como fator migratório: silêncios teóricos e evidências históricas". In: Travessia. n.25, São Paulo: CEM, 1996. p. 5-9.

.__. "Estado e migrações no Brasil - anotações para uma história das políticas migratórias". In: Travessia. n.36. São Paulo: CEM, jan./abr. de 2000. p.15-32.

_. "Reflexões sobre o poder de mobilizar e imobilizar na contemporaneidade". In: POVOA NETO; FERREIRA (org.). Cruzando fronteiras disciplinares. Rio de Janeiro: Niem/ Revan, 2005.

VAZAPOLLO, Luciano. O trabalho atípico e a precariedade. São Paulo: Expressão Popular, 2005.

VETTORASSI, Andréa. "Vivendo e aprendendo a jogar". In: Travessias na Desordem Global. São Paulo: Paulinas, 2005.

VILLAÇA, Flávio. A estrutura territorial da metrópole sul brasileira: áreas residenciais e comerciais. Tese de Doutorado. São Paulo: Departamento de Geografia da FFLCH/ USP, 1978. 358 p.

WOORTMANN, Klaas A. W. A Família Trabalhadora. Série Antropologia, n.40. Brasília: [Mimeo], 1984. pp.69-87.

ZAMBIASI, Alberto R. e MORÉS, Alvídio. “A Realidade sobre a migração brasileira”. In: Travessia. n.52, São Paulo: CEM, 2005 pp.5-16. 


\section{Periódicos}

Ceagesp, Jornal da Cia. de Entrepostos e Armazéns Gerais de S. Paulo. n.1. Ano 1. São Paulo, junho de 1999

Jornal da Ceagesp, n. 1Ano I. São Paulo, junho de 1976.

Jornal Ceagente. n.1. Ano I. São Paulo, agosto de 1976.

_. n.2. Ano I São Paulo, setembro de 1976.

__. n.3. Ano I São Paulo, outubro de 1976.

_.. n.5. Ano I São Paulo, dezembro de 1976.

__. n.6. Ano II São Paulo, janeiro de 1977.

_.. (Ano IV. São Paulo, maio de 1979.

_. n.90. Ano IX. São Paulo, junho/julho de 1984.

Jornal Elo. São Paulo, outubro de 1999. n.15Ano II.

_.. São Paulo, novembro de 1999. n.16Ano II.

_. São Paulo, dezembro de 1999. n.17Ano II.

_.. São Paulo, janeiro de 2000. n.18Ano III.

__. São Paulo, fevereiro de 2000. n.19Ano III.

_. São Paulo, março de 2000. n.20. Ano III. Edição Especial: 34 anos do maior Entreposto de Abastecimento da América Latina.

_. São Paulo, abril de 2000. n.21. Ano III.

_. São Paulo, maio de 2000. n.22. Ano III

Jornal EntrePosto. São Paulo, junho de 2000. n.1. Ano 1 .

_. São Paulo, julho de 2000. n.2. Ano 1.

_. São Paulo, agosto de 2000. n.3. Ano 1.

_. São Paulo, setembro de 2000. n.4. Ano 1.

_. São Paulo, outubro de 2000. n.5. Ano 1.

_. São Paulo, novembro de 2000. n.6. Ano1.

_. São Paulo, dezembro de 2000. n.7. Ano 1.

__. São Paulo, janeiro de 2001. n.8 .Ano 2.

_. São Paulo, fevereiro de 2001. n.9. Ano 2

_.. São Paulo, março de 2001. n.10. Ano 2

_. Suplemento Especial: comemoração dos 35 anos do Entreposto Terminal de São Paulo. (março de 2001)

São Paulo, abril de 2001. n.11, Ano 2. 
. São Paulo, maio de 2001. n.12, Ano 2.

_. São Paulo, junho de 2001. n.13, Ano 2.

_. São Paulo, julho de 2001. n.14, Ano 2.

_. São Paulo, agosto de 2001. n. 15, Ano 2.

_. São Paulo, setembro de 2001. n.16. Ano 2.

_. São Paulo, novembro de 2001. n.17. Ano 2.

_. São Paulo, dezembro de 2001. n.18. Ano 2.

_. São Paulo, janeiro de 2002. n.19. Ano 3.

_. São Paulo, março de 2002. n.21. Ano 3.

_. São Paulo, maio de 2002. n.23. Ano 3.

_. São Paulo, junho de 2002. n.25. Ano 3.

_. São Paulo, julho de 2002. n.26. Ano 3.

_. São Paulo, agosto de 2002. n.27. Ano 3.

_. São Paulo, setembro de 2002. n.28. Ano 3.

_. São Paulo, outubro de 2002. n.29. Ano 3.

_. São Paulo, setembro de 2003. n.40, Ano 4.

_. São Paulo, janeiro de 2004. n.44. Ano 5.

_. São Paulo, fevereiro de 2004. n.45, Ano 5.

_. São Paulo, março de 2004. n.46. Ano 5.

_.. São Paulo, abril de 2004. n.47. Ano 5.

_. São Paulo, maio de 2004. n.48. Ano 5.

_. São Paulo, junho de 2004. n.49. Ano 5.

_. São Paulo, julho de 2004. n.50. Ano 5.

_. São Paulo, agosto de 2004. n.51. Ano 5.

_. São Paulo, setembro de 2004. n.52. Na.o 5.

_.. São Paulo, outubro de 2004. n.53, Ano 5.

_. São Paulo, novembro de 2004. n.54. Ano 5.

_. São Paulo, dezembro de 2004. n.55. Ano 5.

_. São Paulo, Janeiro de 2005. n.56. Ano 6.

_. São Paulo, março de 2005. n.58. Ano 6.

_. São Paulo, abril de 2005. n.59. Ano 6.

_. São Paulo, maio de 2005. n.60. Ano 6.

_. São Paulo, Junho de 2005. n.61. Ano 6.

_.. São Paulo, Julho de 2005. n.62. Ano 6. 
. São Paulo, agosto de 2005. n.63. Ano 6.

. São Paulo, setembro de 2005. n.64. Ano 6.

. São Paulo, outubro de 2005. n.65. Ano 6.

_. São Paulo, novembro de 2005. n.66. Ano 6.

_. São Paulo, dezembro de 2005. n.67. Ano 6.

_. São Paulo, janeiro de 2006. n.68. Ano 7.

_. São Paulo, fevereiro de 2006. n.69. Ano 7.

_. São Paulo, março de 2006. n.70. Ano 7.

_. São Paulo, abril de 2006. n.71. Ano 7.

_. São Paulo, maio de 2006. n.72. Ano 7.

_. São Paulo, julho de 2006. n.74. Ano 7.

_. São Paulo, setembro de 2006. n.76. Ano 7.

Jornal Mercado Paulista. São Paulo, maio de 2005. n.1. Ano 1.

\section{Artigos em jornais}

O Estado de São Paulo, 20 de março de 1982.

TOLEDO, José Roberto de. “ Migrantes são 32,2\% da população da Grande São Paulo”. Caderno Cotidiano. Folha de São Paulo. São Paulo, 22/08/1996.

BEZERRA, Francis. Jornal Eco Nordestino. São Paulo, outubro de 2001.

Jornal Entre Posto. Circulação no ETSP da Ceagesp. Ano 3. n.23. São Paulo, maio de 2002.

BILLI, Marcelo; ZAFALON, Mauro. "Ceasa deixa cidade em busca de eficiência”. Folha de São Paulo, São Paulo, 31/03/2002.

ROLLI, Cláudia e FERNANDES, Fátima. "Dupla vida de Ceagesp gira R\$ 5 mi por dia em ‘negócios”". Caderno Dinheiro. Folha de São Paulo. São Paulo, 18/11/2001). pp.B3-4.

GARBIN, Luciana. "Muda o cenário na Vila Leopoldina”. Caderno Cidades. O Estado de São Paulo. São Paulo, 18/11/2001.

GEDANKEN, Dan. O futuro mora ao lado. Exame, ed.749. n.8. São Paulo, set. de 2001. p. 22-25.

DURAN, Sérgio e BARROS, Guilherme. "Zona Oeste terá centro empresarial e cultural". Caderno Cotidiano. Folha de São Paulo. São Paulo, 14/02/2002.

“Esta área será da Fapesp”. Jornal da Gente - Lapa. São Paulo, 15 a 21 de junho de 2002.

"Primeiro Alívio". Veja SP. São Paulo, 23 de outubro de 2002. 
CINTRA, Miriam. “A Ceagesp buscando Fome Zero”. Linha Direta. n.574. São Paulo, de 25 de maio a 1 de junho de 2003. pp.4-5.

“O Estado de São Paulo continua o principal pólo dos migrantes do país”. SP Demográfico.

Resenha mensal. São Paulo: SEADE. n.6. Ano 4, setembro de 2003.

"Centro é pólo nordestino na cidade". Caderno Especial_- 450 anos da cidade.

Folha de São Paulo. São Paulo, 25/01/2004.

“Carnaval Brasileiro”. São Paulo: Escala, 2004.

FRANCO, Carlos. "A cidade das frutas, flores e 50 mil pessoas". Caderno Economia. $O$ Estado de São Paulo. São Paulo, 25/04/2004.

CARDOSO, Cíntia. "Feira perde 'freguesia' para supermercado". Caderno Dinheiro. Folha de São Paulo. São Paulo, 25/04/2004.

"Prefeitura e estado preparam ação conjunta". Caderno Cotidiano. Folha de São Paulo. São Paulo, 08/05/2005.

GALLO, Rodrigo. “Chuva provoca R\$ 3,5 milhões de prejuízo Ceagesp”. Agência Estado. Último Segundo. São Paulo, 25/05/05. Em: <http://ultimosegundo.ig.com.br> , acesso em 2005.

LAGE, Amarílis e et alii. "Sem Ceagesp, produtor vende fruta na rua”. Caderno Cotidiano. Folha de São Paulo. São Paulo, 27.05.05.

“Ceagesp reabre com produtos mais caros". Caderno Cotidiano. Folha de São Paulo. São Paulo, 28/05/05.

CONSTANTINO, Luciana. "Nordestinos deixam SP e migram de volta". Caderno Cotidiano. Folha de São Paulo. São Paulo, 23/04/2006.

\section{Documentário e filmografia}

CAPOVILLE, Maurice; ANDRADE, Rudá de. O pão nosso de cada dia. São Paulo: ECA/ USP, 1973.

MORALES, Fatima. Os carregadores do CEASA. São Paulo: ECA/ USP, 1972.

VILLAS BOAS, Thiago. Casa de cachorro. São Paulo: ECA/ USP, 2001. 


\section{Sites pesquisados}

IBGE: <www.ibge.gov.br> acesso em 8/2001 e em 01/2005.

DIAS, Tita (vereadora). Rebele-se: <www.rebele-se.org.br> acesso em 20/12/2004.

CEAGESP: <www.ceagesp.gov.br> acesso em 10/01/2004 e 12/05/2006.

INTEGRA: <www.integra.com.br> acesso em 09/10/2004.

ÚLTIMO SEGUNDO: 〈http://ultimosegundo.ig.br> acesso em 27/05/2005.

ACNIELSEN: <www.acnielsen.com.br> acesso em 20/01/2007.

PREFEITURA DE SÃO PAULO: <www.prefeitura.sp.gov.br > acesso em 02/02/2007

CENTRO DE ESTUDOS DA METRÓPOLE: <www.vitruvius.com.br> acesso em 24/03/2007.

SEADE: <www.seade.gov.br> acesso em 07/04/2007.

DIEESE: <www.dieese.ong.br> acesso em 07/04/2007.

APAS: <www.apas.com.br> acesso em 08/04/2007.

\section{Cartas, Mapas e Bases Cartográficas Digitais}

BALLANOTTI, J. L.; MARQUES, M. B. Atlas para definição de políticas sociais no estado de São Paulo. São Paulo: SCFBES, 1994.

INFOLOCAL, Sistema de Informação para Planejamento Local -SEMPLA - DEINFO Departamento de Informações - Prefeitura do Município de São Paulo

SECRETARIA MUNICIPAL DE HABITAÇÃO 
ANEXOS 
Anexo 1: Entrada de Imigrantes e Nacionais em São Paulo entre 1870 e 1901

\begin{tabular}{|c|c|c|c|}
\hline \multirow{2}{*}{ Ano } & \multicolumn{3}{|c|}{ Quantidade } \\
\hline & Kacionais (1) & Nacionais (2) & Imigrantes (3) \\
\hline 1870 & - & & 159 \\
\hline 1871 & 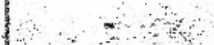 & & 83 \\
\hline 1872 & - & & 323 \\
\hline 1873 & -8 & & 590 \\
\hline 1874 & - & & 120 \\
\hline 1875 & 2 & 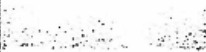 & 3.289 \\
\hline 1876 & 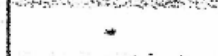 & & .1 .303 \\
\hline 187 & - & & 2.832 \\
\hline 1878 & 380 & $1.300(4)$ & 1.678 \\
\hline 1879 & 80 & 14 & 953 \\
\hline 1880 & - & & 613 \\
\hline 1881 & 4 & & 2.705 \\
\hline 1882 & - & & 2.743 \\
\hline 1889 & +8 & & 4.912 \\
\hline 1884 & 11 & & 4.868 \\
\hline 1885 & - & & 6.500 \\
\hline 1886 & 2 & & 9.534 \\
\hline 1887 & 2 & & $1+32.110$ \\
\hline 1888 & 260 & 739 & 91.826 \\
\hline 1889 & 199 & 2.153 & 27.694 \\
\hline 1890 & - & & 38.291 \\
\hline 1891 & 48 & & 108.688 \\
\hline 1892 & - & & 42.061 \\
\hline 1893. & +4 & & 81745 \\
\hline 1894 & - & & 48.947 \\
\hline 1895 & nes & 8 & 139.998 \\
\hline 1896 & " & & 99.010 \\
\hline 1897 & $\therefore$ & & 98.134 \\
\hline 1898 & - & & 46.939 \\
\hline 1899 & 433 & & 31,172 \\
\hline 1900 & - & 324 & 22.802 \\
\hline 1901 & -1.434 & 1219 & 70348 \\
\hline TOTAL & 2399 & $4.649(4)$ & 1.022 .970 \\
\hline
\end{tabular}

Fontes:

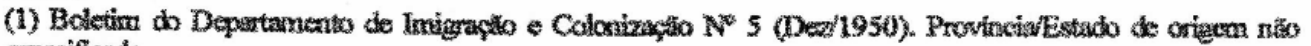
expecificado.

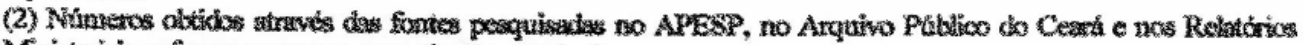

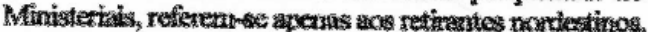

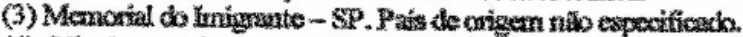

(4) Citcribo aproximato (contome telotas $3.1,3.2$ *3.3)

Fonte: GONÇALVES (2002) 
Anexo 2:

Roteiro das migrações para o Estado de São Paulo (mapa 1)*

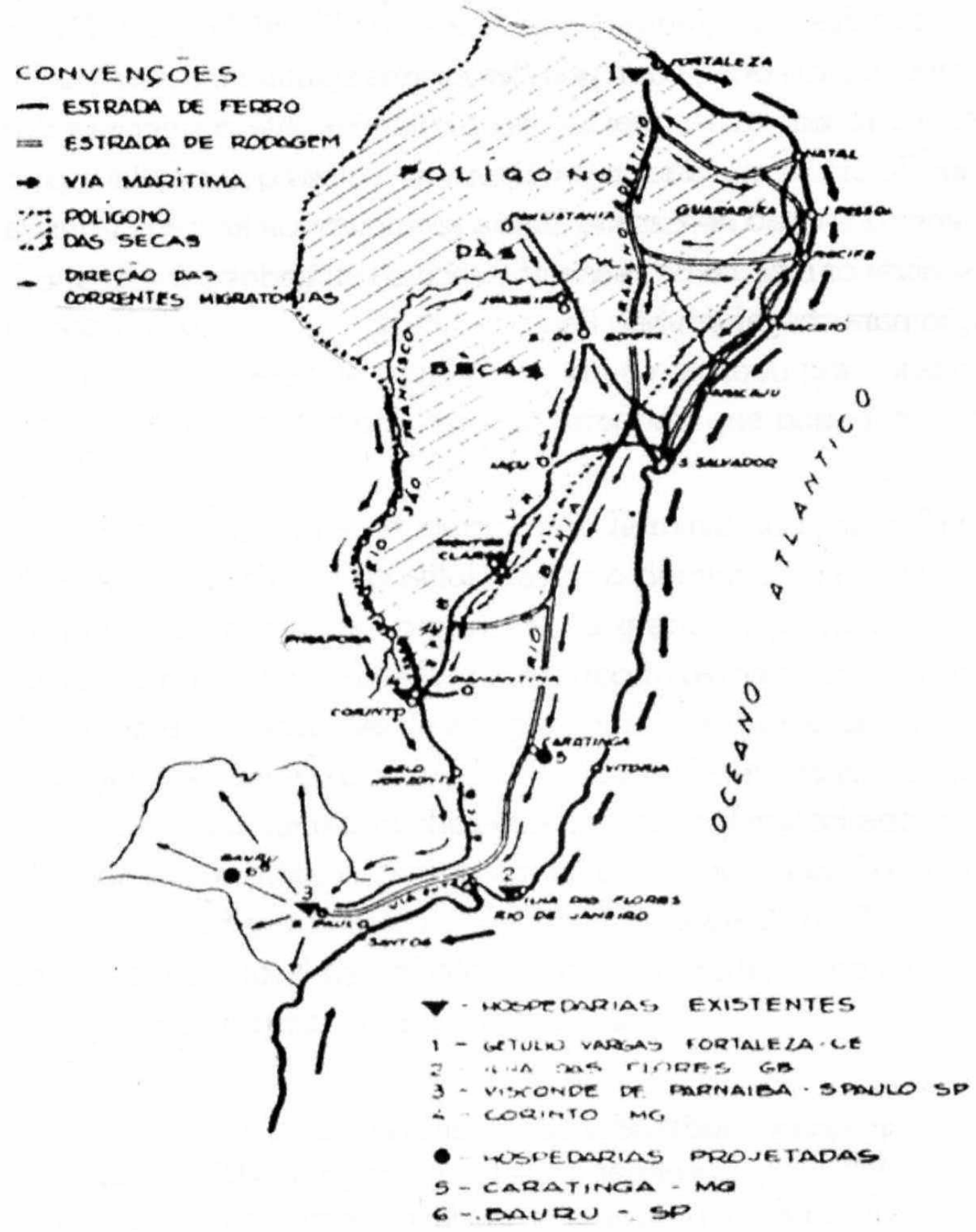

* Fonte: Secretaria da Agricultura, Indústria e Comércio de São Paulo(1951). Boletim do Departamento de Imigração e Colonização do Estado de São Paulo. São Paulo, ano 06, vol.06.

Fonte: RIGAMONTE (2001) 
Anexo 3:

Pontos de referência: migrantes nordestinos pela cidade (Mapa 2)

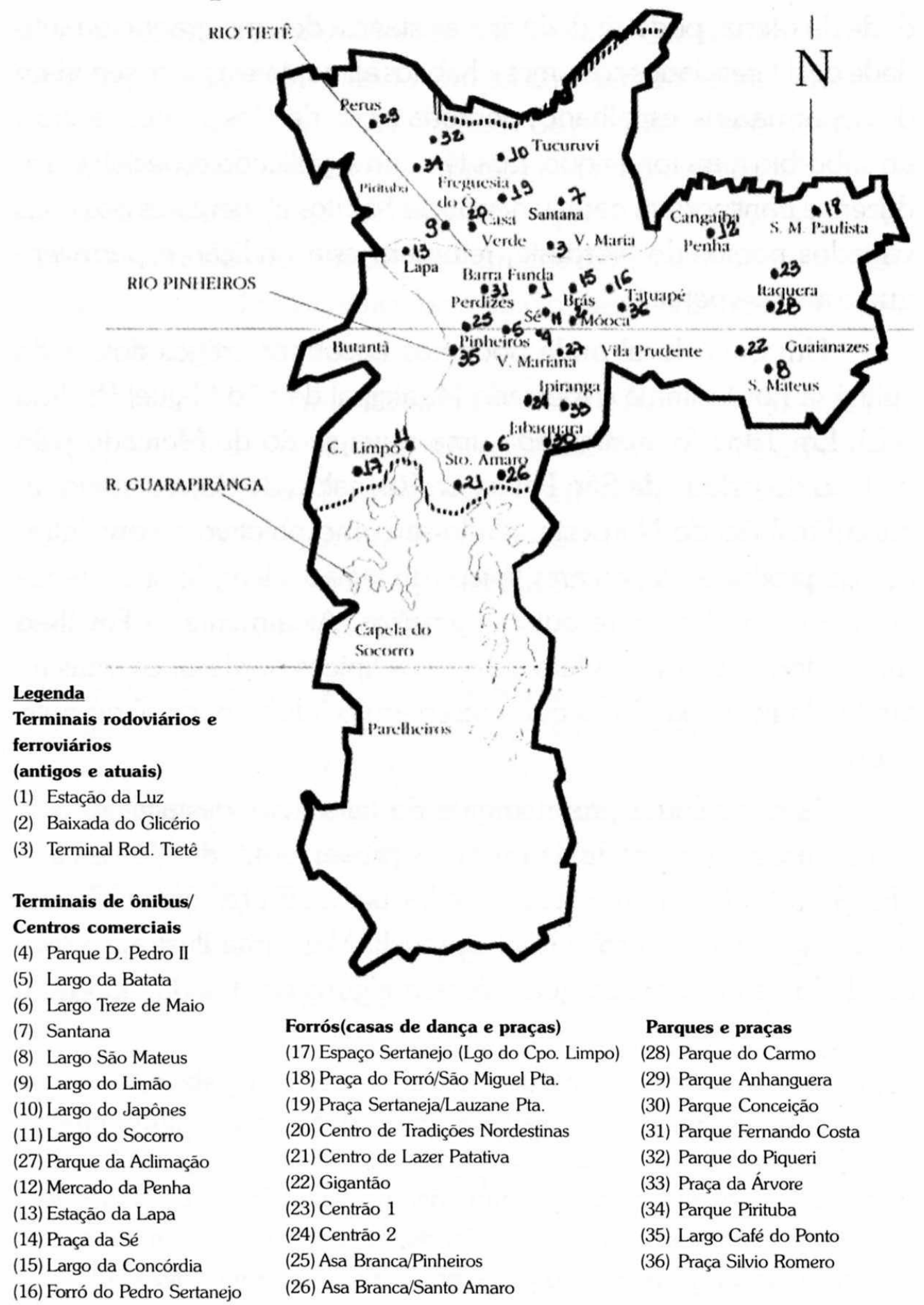

Fonte: RIGAMONTE (2001) 


\section{Anexo 4:}

Tabela 1: Participação dos Migrantes Nordestinos na R.M.S.P, 2000

\begin{tabular}{|c|c|c|c|c|}
\hline & $\begin{array}{l}\text { Migrantes } \\
\text { Nordestinos: }\end{array}$ & Pop. Total (hab.): & $\begin{array}{l}\text { Participação dos } \\
\text { Nordestinos }(\%)\end{array}$ & Área $\left(\mathrm{Km}^{2}\right)$ \\
\hline 1- Arujá & 1531 & 59.185 & 2,59 & 97,45 \\
\hline 2- Barueri & 7438 & 208.281 & 3,57 & 64,17 \\
\hline 3- Biritiba-Mirirm & 194 & 24.653 & 0,79 & 316,72 \\
\hline 4-Cajamar & 1748 & 50.761 & 3,44 & 128,36 \\
\hline 5-Carapicuíba & 10938 & 334.596 & 3,27 & 34,97 \\
\hline 6-Caieiras & 1469 & 71.221 & 2,06 & 95,89 \\
\hline 7-Cotia & 3411 & 148.987 & 2,29 & 323,89 \\
\hline 8-Diadema & 13592 & 357.064 & 3,81 & 30,65 \\
\hline 9- Embu & 8525 & 207.663 & 4,11 & 70,08 \\
\hline 10-Embu Guaçu & 970 & 56.916 & 1,70 & 155,04 \\
\hline 11-Franco da Rocha & 4110 & 108.122 & 3,80 & 133,93 \\
\hline 12-Francisco Mora. & 5532 & 133.738 & 4,14 & 49,16 \\
\hline 13-Ferraz de Vasc. & 4793 & 142377 & 3,37 & 30,07 \\
\hline 14-Guararema & 147 & 21.904 & 0,67 & 270,50 \\
\hline 15- Guarulhos & 43684 & 1.072 .717 & 4,07 & 318,01 \\
\hline 16-Itapevi & 4360 & 162.433 & 2,68 & 91,35 \\
\hline 17-Itapecerica da S. & 3947 & 129.685 & 3,04 & 151,46 \\
\hline 18- Jandira & 2427 & 91.807 & 2,64 & 17,52 \\
\hline 19- Itaquecetuba & 10263 & 272.942 & 3,76 & 81,78 \\
\hline 20-Juquitiba & 683 & 26.459 & 2,58 & 521,60 \\
\hline 21 -Mauá & 11117 & 363.392 & 3,06 & 62,29 \\
\hline 22 -Mairiporã & 1529 & 60.111 & 2,54 & 321,46 \\
\hline 23-Mogi das Cruzes & 4489 & 330.241 & 1,36 & 714,16 \\
\hline $24-$ Osasco & 19144 & 652.593 & 2,93 & 64,94 \\
\hline 25- PiraporaB. Jesus & 85 & 12.395 & 0,69 & 108,26 \\
\hline 26 -Poá & 1304 & 95.801 & 1,36 & 17,18 \\
\hline 27 -Ribeirão Pires & 1887 & 104.508 & 1,81 & 99,18 \\
\hline 28 -Rio G. da Serra & 967 & 37.091 & 2,61 & 36,67 \\
\hline 29 -Salesópolis & 107 & 14.357 & 0,75 & 425,84 \\
\hline 30 -Santa Isabel & 621 & 43.740 & 1,42 & 361,49 \\
\hline 31 -Santan.Parnaíba & 2481 & 74.828 & 3,32 & 183,82 \\
\hline 32 -Santo André & 13076 & 649.331 & 2,01 & 174,84 \\
\hline 33 -S. Bernardo doC. & 19825 & 703.177 & 2,82 & 406,18 \\
\hline 34 -S.Caetano dSul & 2226 & 140.159 & 1,59 & 15,36 \\
\hline 35 -São Paulo & 271792 & 10.435 .546 & 2,60 & 1522,99 \\
\hline 36-S.LourençodaSe & 1725 & 12.199 & 14,14 & 186,7 \\
\hline 37 - Suzano & 4087 & 228.690 & 1,79 & 205,87 \\
\hline 38 -Taboão daSerra & 6659 & 197644 & 3,37 & 20,48 \\
\hline 39 -Vargem G.Pta. & 644 & 32.683 & 1,97 & 33,51 \\
\hline Subtotal & & 17.869 .997 & 2,76 & \\
\hline TOTAL: & 493595 & & & \\
\hline
\end{tabular}

Dados preliminares do Censo de 2000 - IBGE , em que considera pessoas não residentes no município em 01/09/1991, com

4 anos ou mais de idade. Fonte: www.ibge.gov. Br

Elaboração: Sueli de Castro Gomes 


\section{Anexo 5:}

Área de Expansão da Migração Nordestina

Estado de São Paulo.1986-1991 e 1991-1996

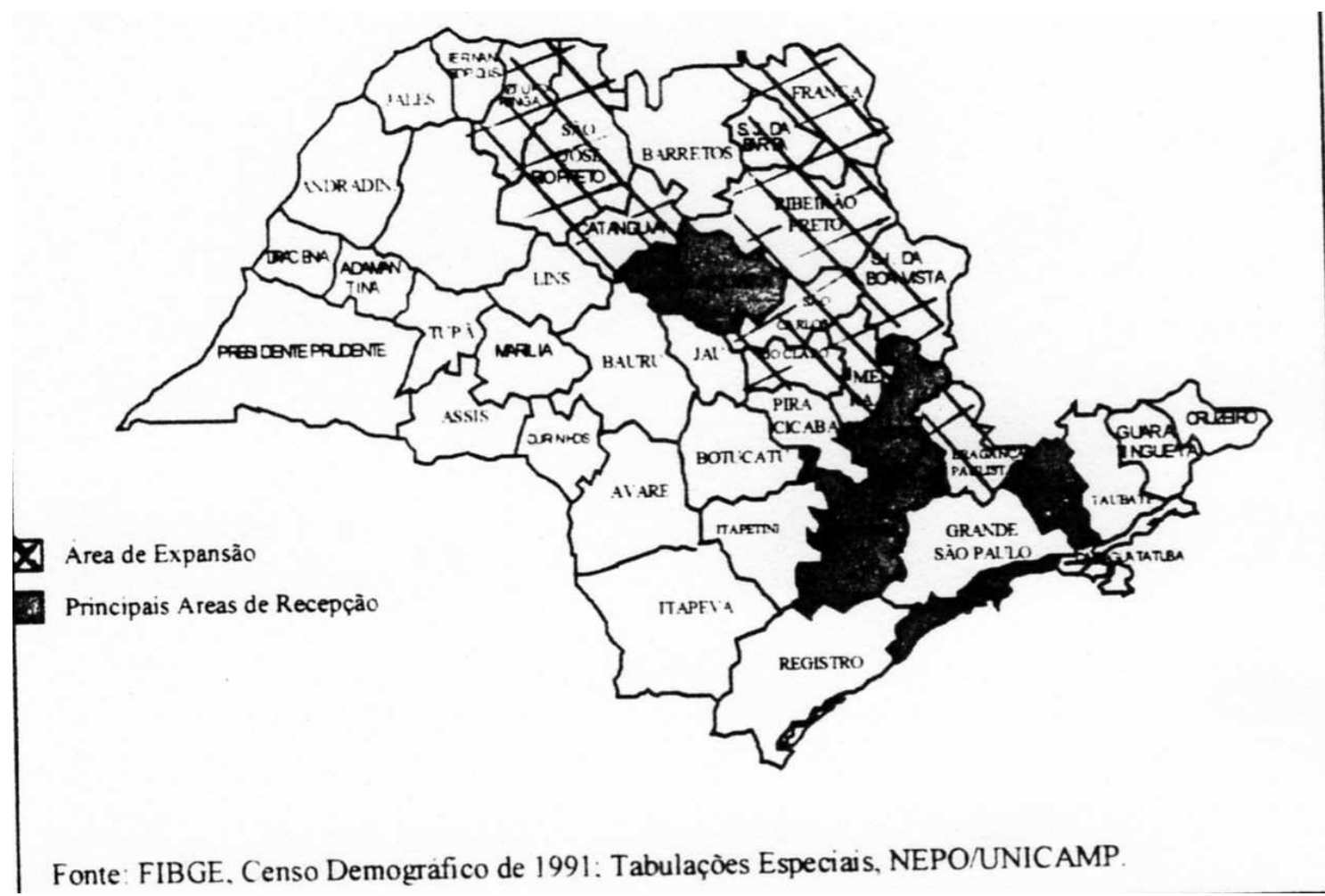

\section{Anexo 6}

Proporçào da Migração Nordestina no total do Morimento Mfigratório Interestadual

Principais Regiòes de Migrantes Interestaduais

Estado de Sào Paulo

1986-1991 e 1991-1996

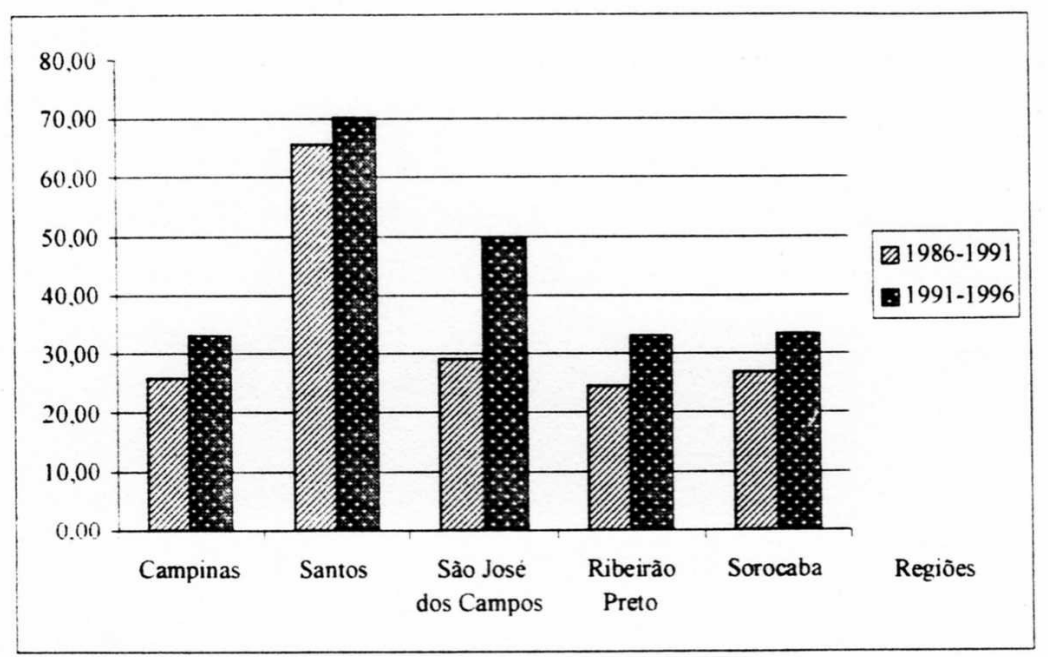

Fonte: FIBGE, Censo Demográfico de 1991 e Contagem de População de 1996; Tabulações Especiais, NEPO/LNIC.AIIP. 
Anexo 7
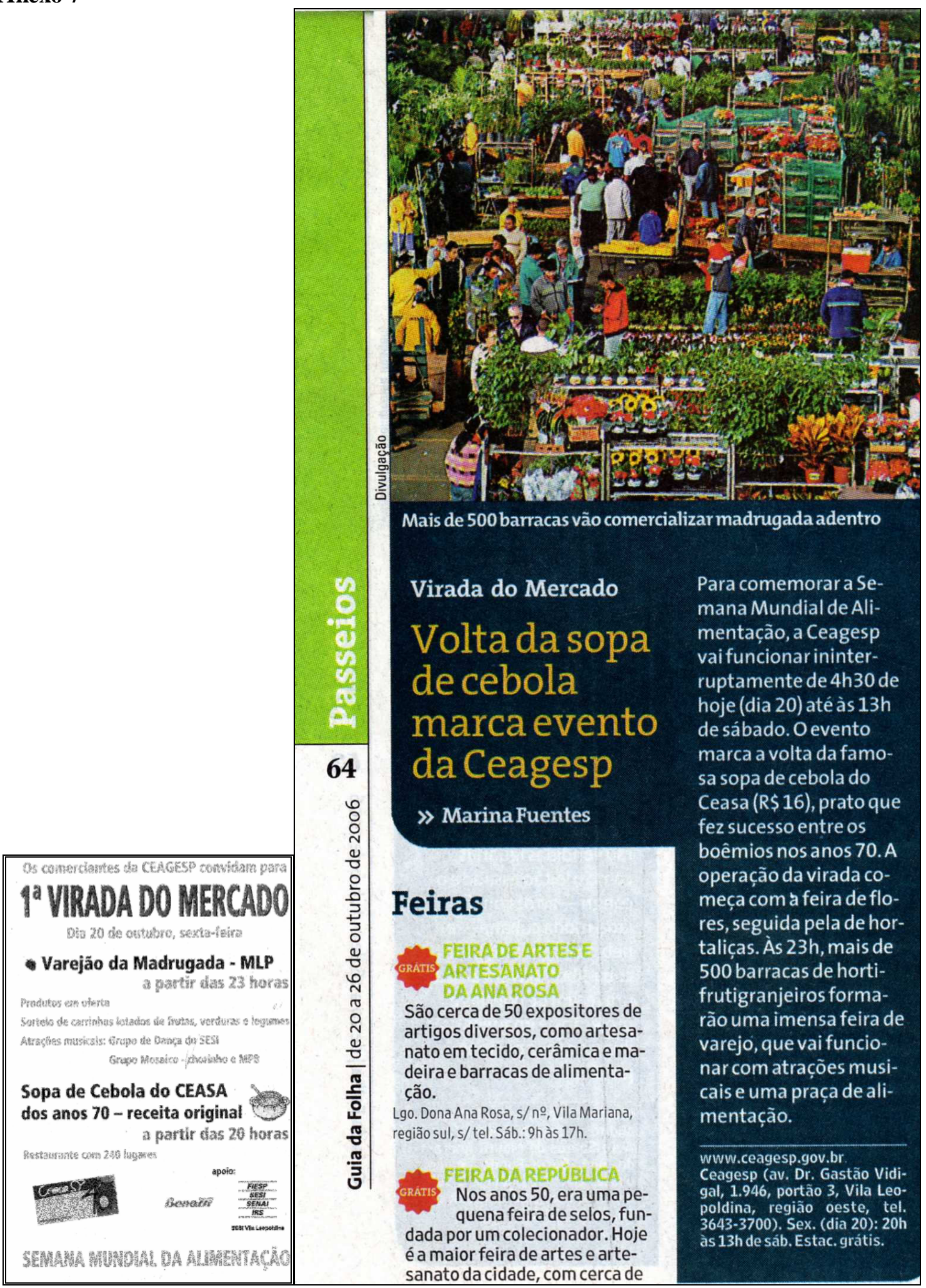

Fonte: Folha de São Paulo, 20 de outubro de 2006 
Anexo 8

\section{ACADÊMICOS DO TUCURUVI}

Samba-enredo: "Tá na mesa? Ceagesp É Fome Zero"

Compositores: Luis Ferracini, Vaguinho, Alencar e Murilo TK

Desperta amor, já clareou!

Suinga minha bateria

É Tucuruvi pode aplaudir

Um prato cheio de amor e alegria

Vem comemorar, extravasar

Eis aí o nosso Carnaval

São Paulo um eldorado de esplendor

Viu nascer com muito amor

A Ceagesp um megacentro genial

Que então cresceu, desenvolveu

Brilhando no comércio nacional

Tudo de primeira, para o seu paladar

Vem, pode provar

Oi paga um leva dois, alô quem vai

Moça bonita não paga

Mesmo chorando não leva

Eu quero é mais

Chega de ver

O povo não Ter para comer

Abra o seu coração

Dê para receber

Solidariedade sim

E o desperdício vai Ter fim

Fome Zero é isso aí, é lutar!

É acreditar, é contribuir

É união

A Ceagesp levanta a bandeira

Para reverter esta situação 
Observação: As tabelas 7, 8, 9,10,11,12, 13 e 14 foram produzidas a partir de 280 entrevistas com usuários do Terminal da CEAGESP. Então, quantidade de usuários está identificada na coluna "Quant”.

\section{Anexos 9 e 10}

Tabela 7- Regiões, Brasil e Mercosul, de Destino das Mercadorias.

\begin{tabular}{|l|r|r|}
\hline \multicolumn{1}{|c|}{ Regibes } & Quant & $\%$ \\
\hline Regiåo Norte & 2 & 0,71 \\
\hline Regiăo Nordeste & 1 & 0,36 \\
\hline Regiáo Centro-Oeste & 4 & 1,43 \\
\hline Regiao Sul & 19 & 6,79 \\
\hline Região Sudeste & 107 & 38,21 \\
\hline Grande Sao Paulo & 142 & 50,71 \\
\hline Mercosul & 1 & 0,36 \\
\hline Ná ldentificado & 4 & 1,43 \\
\hline TOTAL & 280 & 100,00 \\
\hline
\end{tabular}

(1) Regín Sudeste exe ato a Grande Sáo Paub (Mrunicipio de Săo Paulo, ABCD, Osasco e Guaruthos) Font: Pesquisa de Campo realizada em 17/05/2004, pelo LPTiEPUSP.

Tabela 8- Estados, da Região Sudeste, de Destino das Mercadorias.

\begin{tabular}{|l|r|r|}
\hline \multicolumn{1}{|c|}{ Estado } & Quant & $\%$ \\
\hline Rio de Janeiro & 6 & 5,61 \\
\hline Minas Gerais & 8 & 7,48 \\
\hline Espirito Santo & 2 & 1,87 \\
\hline Sao Paulo $^{1}$ & 91 & 85,05 \\
\hline TOTAL & 107 & 100,00 \\
\hline
\end{tabular}

(1) Estato de Saึo Pauto exceto a Grande São Paulo (Muricipio de Såo Pauto, ABCD, Osasco e Guarthos) Fonte: Pesquisa de Campo realizada em 1705/2004, peio LPT/EPUSP.

Anexos 11 e 12 
Tabela 9- Regiões e Municípios, do Estado de São Paulo, de Destino das Mercadonias.

\begin{tabular}{|l|r|r|}
\hline Regióes e Municípios & Quant & $\%$ \\
\hline Interior & 80 & 34,33 \\
\hline Litoral & 11 & 4,72 \\
\hline SubTotal & 91 & 39,06 \\
\hline Município de São Paulo & 110 & 47,21 \\
\hline ABCD & 15 & 6,44 \\
\hline Osasco & 8 & 3,43 \\
\hline Guarulhos & 9 & 3,86 \\
\hline Grande São Paulo & 142 & 60,94 \\
\hline TOTAL & 233 & 100,00 \\
\hline
\end{tabular}

Fonte: Pesquisa de Campo realizada em 17/05/2004, pelo LPT/EPUSP.

Tabela 10- Destino das Mercadonias por Zonas e Municipios da Região Metropolitana de São Paulo.

\begin{tabular}{|l|r|r|}
\hline \multicolumn{1}{|c|}{ Zonas e Municipios } & Quant & $\%$ \\
\hline Zona Leste & 20 & 14,08 \\
\hline Zona Oeste & 29 & 20,42 \\
\hline Zona Sul & 33 & 23,24 \\
\hline Zona Norte & 15 & 10,56 \\
\hline Centro & 8 & 5,63 \\
\hline Mais de uma Zona & 5 & 3,52 \\
\hline Municipio de Săo Paulo & 110 & 77,46 \\
\hline ABCD & 15 & 10,56 \\
\hline Osasco & 8 & 5,63 \\
\hline Guarulhos & 9 & 6,34 \\
\hline Regiåo Metropolitana de Sä Paulo & 142 & 100,00 \\
\hline Fonte: Posquisa di Campo reailiza em 1705/2004, peio LPTEPUSP.
\end{tabular}

\section{Anexos 13 e 14}


Taboia 11. Destino das Mercadorias Comercializadas, segundo a Natureza do Destirnatário.

\begin{tabular}{|c|c|c|}
\hline Destinatario & Quant & $\%$ \\
\hline Sem especificacáo & 47 & 1679 \\
\hline freira-live & 36 & 12,85 \\
\hline Supemercado & 35 & 12,50 \\
\hline Sacolso & 34 & 12,14 \\
\hline Mercado & 21 & 7,50 \\
\hline Produtor & 20 & 7,14 \\
\hline Varega & 18 & 6,43 \\
\hline Distribuichora & 33 & 4,64 \\
\hline Restaurantentotel & 12 & 4,29 \\
\hline Outros Ceasas & 12 & 4,29 \\
\hline Coublanda & 8 & 2,86 \\
\hline Arrnazem & 5 & 1,79 \\
\hline Hospibalfescola & 3 & 1.07 \\
\hline Entregas & 3 & 1,07 \\
\hline Antryiaritas & 2 & 0,71 \\
\hline Dharsos & 5 & 1.79 \\
\hline Lojas & 2 & 0.71 \\
\hline Empresa & 1 & 0,36 \\
\hline Frina de exportacko & 1 & 0,35 \\
\hline Frigontico & 1 & 0,36 \\
\hline Frutaria & 1 & 0,36 \\
\hline TOTAL & 280 & 102,00 \\
\hline
\end{tabular}

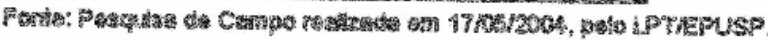

Tabela 12- Destino das Motcadorias Comexciatizadas, segundo o Tipo de Carga.

\begin{tabular}{|c|c|c|}
\hline Thoo de Carga & Quant & $\%$ \\
\hline Vaflas & 67 & 23,93 \\
\hline Erukas & 591 & 21,07 \\
\hline Vazo & 311 & 11,07 \\
\hline Frutus o Legumes & 29 & 10,36 \\
\hline Legumes & 27 & 9,64 \\
\hline Frukas, Legumes e Verours & 28 & 9,28 \\
\hline Caises Vazias & 21 & 7,50 \\
\hline Nao ldentificado & 8 & 2,85 \\
\hline Cobola, Batata - Mandioca & 5 & 1,79 \\
\hline Verduras & 3 & 1,07 \\
\hline Qutros (rinta, Adubo, etc) & 3 & 1,07 \\
\hline Legumes - Vercuras & 11 & 0,35 \\
\hline Flores & - & 0,00 \\
\hline SOMA & 200 & 100,00 \\
\hline
\end{tabular}

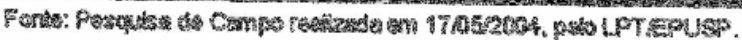

\section{Anexos 15 e 16:}




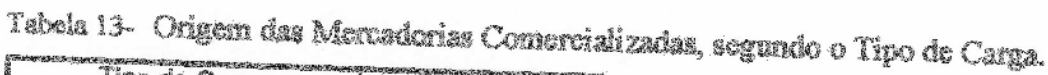

\begin{tabular}{|c|c|c|}
\hline Thes de Gara & Ouand & 管 \\
\hline Yests & |5 & 56.73 \\
\hline Qntwis vories & 31 & 11.07 \\
\hline Fists & 23 & 323 \\
\hline Wrentros & 23 & 7,2 \\
\hline 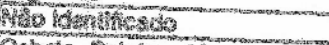 & 13 & S.64 \\
\hline 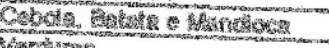 & 12 & 428 \\
\hline Ueroures - & 3 & 1.79 \\
\hline Wfitas & 51 & 1,724 \\
\hline Cutres ond & 3 & 179 \\
\hline 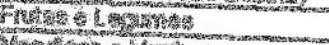 & 3 & $7,0 \%$ \\
\hline Amposs o yorturs & (1) & 0,36 \\
\hline 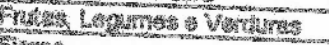 & 11 & 0.35 \\
\hline 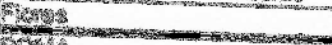 & - & 3,608 \\
\hline $50 x_{19}$ & 201 & 90.6 \\
\hline
\end{tabular}

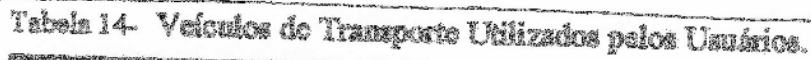

\begin{tabular}{|c|c|c|}
\hline Yomiso & colunt & a \\
\hline S & 11 & $a_{3}$ \\
\hline Wow & 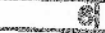 & 215 \\
\hline Nain & 0 & 60 \\
\hline Fyne & 10 & 3.5 \\
\hline 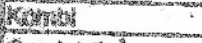 & (19) & 27 \\
\hline \multicolumn{3}{|l|}{ Gratennes" } \\
\hline $\mathrm{Q}^{2} \mathrm{~A}$ & 34 & 86 \\
\hline (2231 & 67 & 186 \\
\hline (92, & 3 & 0.71 \\
\hline Ga, & 21 & 26.23 \\
\hline 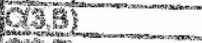 & 16 & 57 \\
\hline 9,, 5 & 2 & \$71 \\
\hline (6) & 12 & 0.3 \\
\hline 898 & D) & 200 \\
\hline 96 & का & 200 \\
\hline 968 & 3 & 107 \\
\hline 9.82 & 2) & $97 \%$ \\
\hline 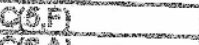 & 11 & 939 \\
\hline Q6.) & (0) & 0.0 \\
\hline 96.8 & 4 & 143 \\
\hline $\mathrm{GSP}=$ & II & 0,38 \\
\hline 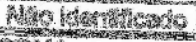 & 3 & 071 \\
\hline ODIA & 20 & 10004 \\
\hline
\end{tabular}

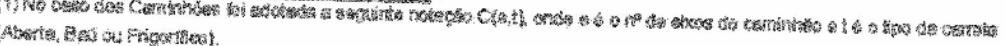

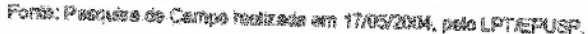

\section{Anexo 17}




(

Anexo 19

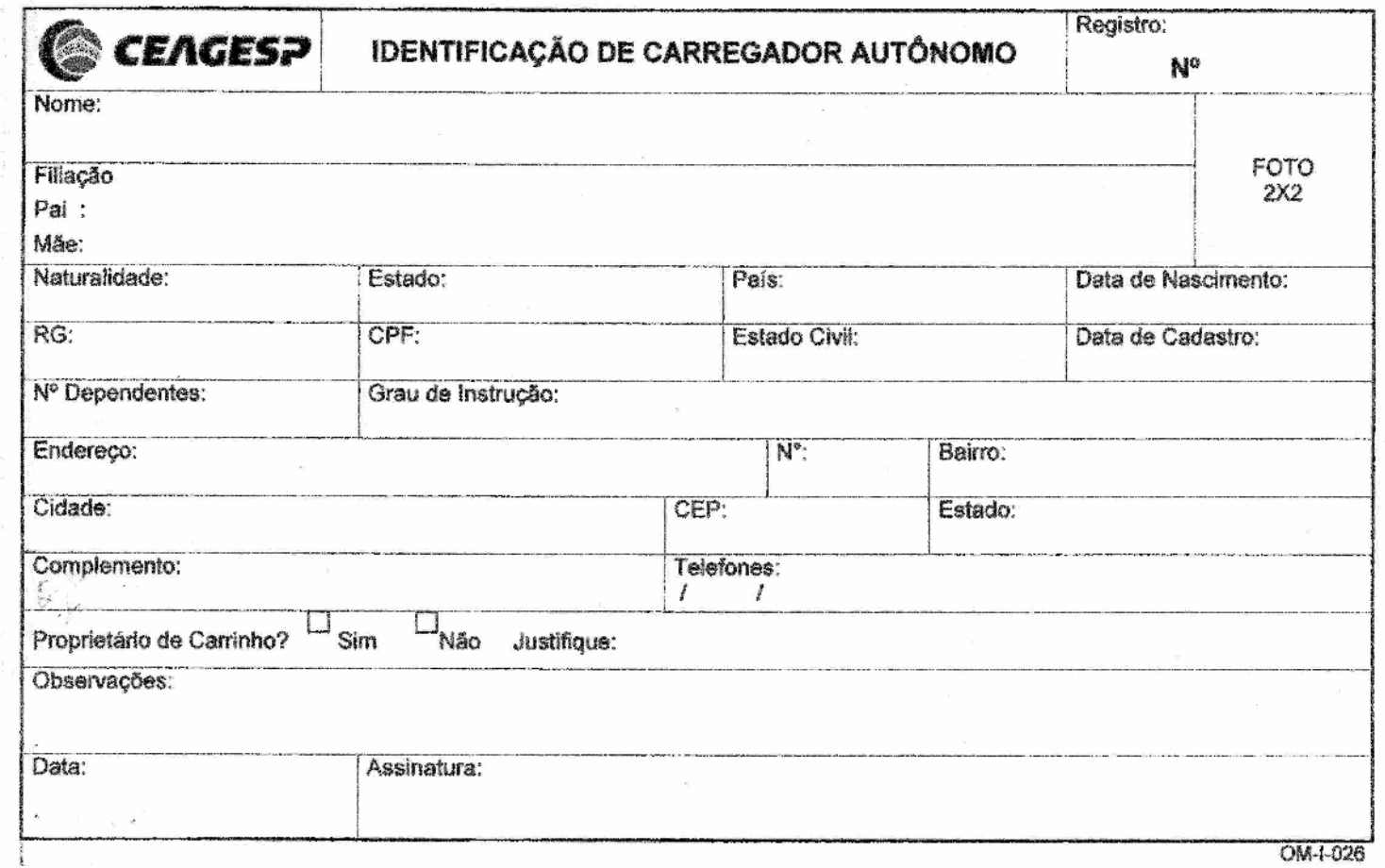

\section{Anexo 18}




\section{YENOEDORES KNBLANTES}

\section{RELACAO DOS DOCUMENTOS SOLGTADOS PELO CEACESP}

\section{XEROX:}

1. CPF

"Para os nâk inscritos requerer em gualquer aguncla dos Correlos,

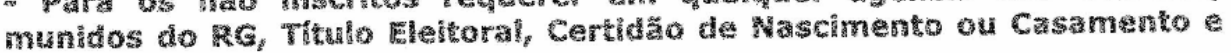
Comprovante de Endereço w

2. RC (Cédula de relentioude)

- Para os que náo possurren devem solicitá-1a junto aO POUPA TEMBO ou no Distritco Policial do balro em que resite - ;

3. 30C (Ficha de dados cadastrais) - Inscrigyo no CCM - Cadastro de Contributrestes Mobiharios.

- Lavar para inscrição: CPF, RG, TPVU, pesquisa do código se

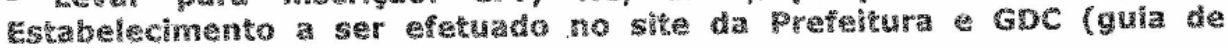
dados cadastrais) preenchida -;

4. DARM (Documento dُ Arrecadaça de Trbutros Mobiliários)

- a ser pago to Eanco após emissẩ antrega da FDC "

5. Inscriça no INSS (Contribuinte Individua Autonomo).

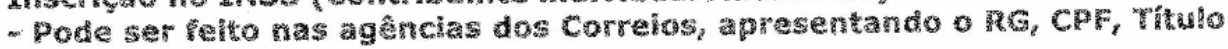
de Eleikor $\mathrm{FDC}-\mathrm{B}$

6. Carno para recolhimento do TNSS a ser adquinio mas papelarias

7. Comprovante de Residencia

\$. Imposto Sindical, a ser fornecïdo pelo Sindicato

- Apresentar $\mathrm{RG}_{y} \mathrm{CP}$ e $\mathrm{FDC}$ - $\hat{i}$

9. gxame mádico

- a ser efetuado em qualquer posto de sabde de sanidade do Governo (Posto de Saŕde do Estado) Ou no STNCAESP (CEASA) -

10. 2 Fotos $2 \times 2$.

os5: O presnchimento dos documentos constante nos litens $3,4,5$ o poderá ser feito no sindicato.

Endereços:

Prefehura do Muticipio de Sü Pauro

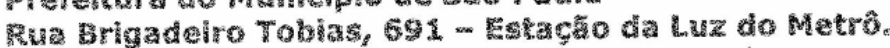

Sind dicato do comercto de Vendedores Ambulandes de São Paulo

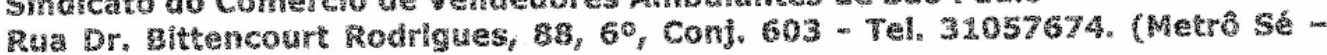
Em trente à Secretaria da razenda). 
Anexo 20:

Tabela : Faixa Etária dos Carregadores do Terminal da CEAGESP

\begin{tabular}{|c|c|c|}
\hline Idade: & Número de trabalhadores: & Participação Relativa (\%): \\
\hline menos de 19 & 3 & 0 \\
\hline 20 a 25 & 160 & 10 \\
\hline 26 a 30 & 334 & 13 \\
\hline 31 a 35 & 453 & 14 \\
\hline 36 a 40 & 497 & 13 \\
\hline 41 a 45 & 480 & 11 \\
\hline 46 a 50 & 369 & 9 \\
\hline 51 a 55 & 294 & 6 \\
\hline 56 a 60 & 192 & 3 \\
\hline 61 a 65 & 94 & 2 \\
\hline 71 a 75 75 & 65 & 1 \\
\hline mais de 76 & 27 & 1 \\
\hline Total: & 20 & 12 \\
\hline Sem Informação: & 2988 & 0 \\
\hline Informações Incorretas: & 413 & \\
\hline Total de carregadores: & 04 & \\
\hline
\end{tabular}

Fonte: CEAGESP (2006)

Org: Sueli de Castro Gomes 
ANEXO 21:

TABELA: IDADE DOS CARREGADORES DO TERMINAL DA CEAGESP

\begin{tabular}{|c|c|c|c|}
\hline Idade: & $\begin{array}{c}\text { Número de } \\
\text { Carregadores }\end{array}$ & Idade: & $\begin{array}{c}\text { Número de } \\
\text { Carregadores }\end{array}$ \\
\hline 105 & 01 & 51 & 62 \\
\hline 86 & 01 & 50 & 69 \\
\hline 82 & 03 & 49 & 69 \\
\hline 81 & 03 & 48 & 86 \\
\hline 80 & 03 & 47 & 71 \\
\hline 79 & 02 & 46 & 74 \\
\hline 77 & 02 & 45 & 88 \\
\hline 76 & 05 & 44 & 90 \\
\hline 75 & 04 & 43 & 101 \\
\hline 74 & 05 & 42 & 108 \\
\hline 73 & 04 & 41 & 93 \\
\hline 72 & 10 & 40 & 97 \\
\hline 71 & 04 & 38 & 104 \\
\hline 70 & 07 & 37 & 99 \\
\hline 69 & 05 & 36 & 104 \\
\hline 68 & 16 & 35 & 83 \\
\hline 67 & 22 & 34 & 102 \\
\hline 66 & 15 & 33 & 97 \\
\hline 65 & 17 & 32 & 87 \\
\hline 64 & 17 & 31 & 84 \\
\hline 63 & 13 & 30 & 73 \\
\hline 62 & 25 & 29 & 66 \\
\hline 61 & 22 & 28 & 66 \\
\hline 60 & 28 & 27 & 73 \\
\hline 59 & 36 & 26 & 56 \\
\hline 58 & 44 & 25 & 55 \\
\hline 57 & 44 & 24 & 36 \\
\hline 56 & 40 & 23 & 42 \\
\hline 55 & 49 & 22 & 21 \\
\hline 54 & 66 & 21 & 06 \\
\hline 53 & 50 & 18 & 02 \\
\hline \multirow[t]{5}{*}{52} & 67 & 16 & 01 \\
\hline & & Total parcial: & 2988 \\
\hline & & $\begin{array}{l}\text { Inform. Incorretas } \\
:\end{array}$ & 04 \\
\hline & & Sem Informação: & 413 \\
\hline & & Soma total: & 3405 \\
\hline
\end{tabular}

Fonte: CEAGESP (2006)

Soma total:

Org. : Sueli de Castro Gomes 
Anexo 22

Tabela : Escolaridade dos Carregadores do Terminal CEAGESP (2006)

\begin{tabular}{|l|c|c|}
\hline Nível de Escolaridade & Número de Carregadores & Participação Relativa (\%) \\
\hline Analfabetos & 406 & 12 \\
\hline Ciclo Básico (C/I) & 162 & 58 \\
\hline $\begin{array}{l}\text { Ensino Fundamental } \\
\text { (Incompleto) }\end{array}$ & 2344 & 9 \\
\hline $\begin{array}{l}\text { Ensino Fundamental } \\
\text { completo) }\end{array}$ & 292 & 2 \\
\hline Ensino Médio Incompleto & 60 & 3 \\
\hline Ensino Médio Completo & 113 & 0 \\
\hline Ensino Superior (C/I) & 5 & 1 \\
\hline Informação ausente & 23 & 100 \\
\hline & 3405 & \\
\hline Total: & & \\
\hline
\end{tabular}

Fonte: Dados Cadastrais do CEAGESP (2006)

Elaboração: Sueli de Castro Gomes 
Anexo 23

\begin{tabular}{|c|c|c|c|c|c|c|c|c|c|}
\hline cencESP & & & DADOS & Aristico & $\begin{array}{l}\text { A TECMO } \\
\text { DE COAERCIALI }\end{array}$ & PERACI & sp & & 4 \\
\hline \multirow{2}{*}{ Mes } & \multicolumn{3}{|c|}{2006} & \multicolumn{3}{|c|}{2005} & \multicolumn{3}{|c|}{ VARLAC6ES 2004/2005 } \\
\hline & TON & VOL. FINANC (RS) & PETTON & TON & VOL FINANC (RS) & RSTTON & TON & WOL FINAANC & RSTTON \\
\hline LANEIRO & 252.620 & $267.589 .955,59$ & $1.059,60$ & 236.965 & 225.175 .672 .55 & 950.25 & $6,6 \%$ & $18,9 \%$ & $11,5 \%$ \\
\hline FEVEREIRO & 235.195 & $252.857 .976,04$ & 1075,52 & 228.085 & 240.271 .527 .55 & $1.053,43$ & $3,1 \%$ & $3,3 \%$ & $3,1 \%$ \\
\hline MARCCO & 268.839 & 292.762 .265 .24 & $\$ .089,00$ & 256.894 & $288.222,492,82$ & $3,122,82$ & $4,7 \%$ & $1,6 \%$ & $-3,0 \%$ \\
\hline ABRIL & 227.199 & $252.738 .034,72$ & $1.112,41$ & 250.555 & $257.231 .316,65$ & $1.028,65$ & $-9,3 \%$ & $-1,7 \%$ & $8,4 \%$ \\
\hline MAIO & 247,028 & $245.710 .958,47$ & g94,57 & 235.922 & $252221.111,43$ & $1.069,09$ & $4,7 \%$ & $-2,6 \%$ & $-7,0 \%$ \\
\hline UNHO & 232.474 & $218.049 .836,53$ & 937,96 & 237.757 & $231.961 .072,28$ & 975,62 & $-2,2 \%$ & $-6,0 \%$ & $3,9 \%$ \\
\hline HULHO & 229.679 & $233.952 .344,18$ & $1.018,60$ & 226.970 & $215.052 .296,46$ & 947,49 & $1,2 \%$ & $8,8 \%$ & $7,5 \%$ \\
\hline AGOSTO & 243.095 & $255,970.431,15$ & $1.052,96$ & 247.773 & $227.485 .651,01$ & 918,04 & $-1,9 \%$ & $12,5 \%$ & $14,7 \%$ \\
\hline SETEANERO & 234.740 & 249.161 .605 .53 & $1.075,19$ & 237.422 & 218.288 .130 .45 & 819,33 & $-2,4 \%$ & $14,2 \%$ & $17,0 \%$ \\
\hline OUTUBe: & 251.508 & $277.590 .165,05$ & $1.103,79$ & 244.397 & $230.542 .243,40$ & 943,31 & $2,9 \%$ & $20,4 \%$ & $17,0 \%$ \\
\hline NOVEMBRO & 260.052 & $285.797 .407,57$ & $1.099,00$ & 243.582 & $258.541 .447,18$ & $1.061,42$ & $6,8 \%$ & $10,5 \%$ & $3,5 \%$ \\
\hline DEZEAMBRO & 277.684 & 352.369 .674 .66 & $1.268,90$ & 289.910 & $-388.817 .669,26$ & $1,456,74$ & $4,0 \%$ & $-4 \%$ & $-12.9 \%$ \\
\hline TOTAL & 2.957 .110 & $3.184 .750 .751,73$ & $1.076,98$ & 2.913 .038 & 3.033.770.551,02 & $1.041,49$ & $1,5 \%$ & $5,0 \%$ & $3,4 \%$ \\
\hline
\end{tabular}

Fonte: seção de economia da CEAGESP (2006) 


\section{Anexo 24}

Tabela : Data de Entrada dos Carregadores do Terminal da CEAGESP (2006)

\begin{tabular}{|c|c|}
\hline Ano de Entrada: & Trabalhadores: \\
\hline
\end{tabular}

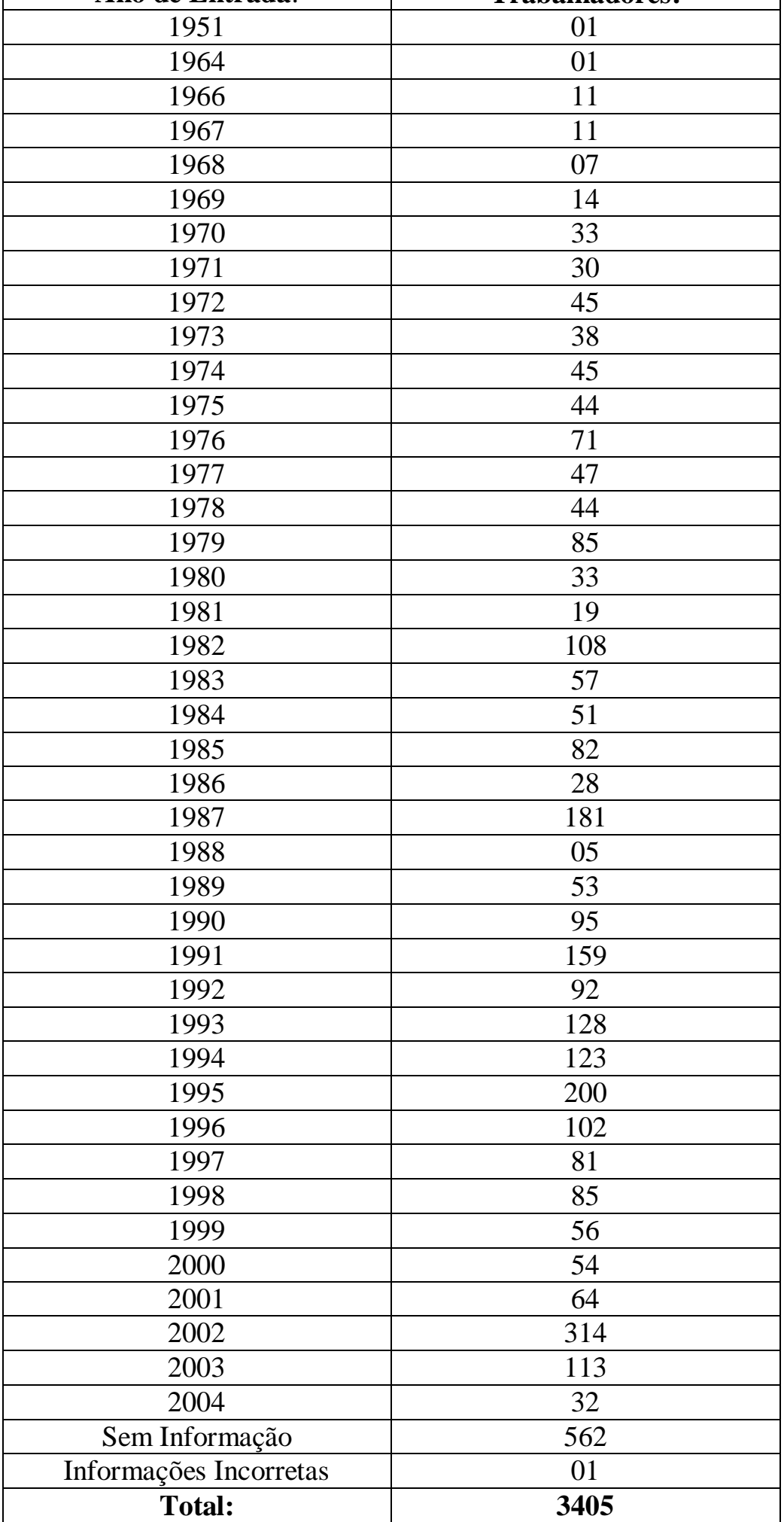

Fonte: CEAGESP (2006) Org.:Sueli de Castro Gomes 
Anexo 25

Tabela : PARTICIPAÇÃO DOS CARREGADORES POR PERÍODO DE INSERÇÃO NO TERMINAL DA CEAGESP(2006)

\begin{tabular}{|l|c|l|}
\hline Período: & Trabalhadores : & Número Relativo: \\
\hline $1966-1970$ & 78 & $3 \%$ \\
\hline $1971-1980$ & 482 & $17 \%$ \\
\hline $1981-1990$ & 679 & $22 \%$ \\
\hline $1991-2000$ & 1080 & $40 \%$ \\
\hline $2000-2004$ & 523 & $18 \%$ \\
\hline Total : & 2842 & $100 \%$ \\
\hline
\end{tabular}

Obs: 563 carregadores não informaram ou informaram datas que não correspondem a esse período.

Fonte: CEAGESP (2006) Org. : Sueli de Castro Gomes 
Anexo 26:

\section{PERMISSIONÁRIO}

Autor: José Daniel Veloso

Senhor Toninho permissionário

Convido para dialogar

Daniel precisa aprender

Acredito poder informar

O lençol de água do Piauí

Possui riqueza exemplar

Futuramente novos pomares no Nordeste podem surgir

nas margens do São Francisco muito podemos produzir

frutos que saborearmos

mas sementes a progredir

O poeta procura seguir

Boas e corretas orientações

Lembra o caja do Piauí

Quando falamos em plantações

Em São Paulo os laranjais

De importantes regiões

Partimos pra outras regiões

Muito temos que respeitar

Espanha, Marrocos, Itália

Possuem vários pomares

Maça e pêra argentina

brasileiros a saborear

A carta vou encerrar

$\mathrm{Na}$ sala da chefia

Entrego a Toninho poeta

Conhecedor da geografia

No sistema hidrográfico

Conhece cada bacia

O senhor Drago com alegria

Sabe muito bem se comportar Se alguém critica ao poeta

Tem direito a se expressar

Agradece ao permissionário

O diretor do Sindicar 
Anexo 27:

Tabela : Estado de Origem dos Carregadores (2006)

\begin{tabular}{|c|c|c|}
\hline Estado: & Número de Carregadores : & Participação Relativa(\%): \\
\hline Piauí & 2276 & 67 \\
\hline Ceará & 499 & 15 \\
\hline São Paulo & 109 & 6 \\
\hline Pernambuco & 112 & 3 \\
\hline Bahia & 87 & 2 \\
\hline Paraíba & 50 & 1 \\
\hline Minas Gerais & 41 & 1 \\
\hline Maranhão & 35 & 1 \\
\hline Alagoas & 25 & $<1$ \\
\hline Rio Grande do Norte & 24 & $<1$ \\
\hline Paraná & 17 & $<1$ \\
\hline Sergipe & 11 & $<1$ \\
\hline Rio de Janeiro & 03 & $<1$ \\
\hline Tocantins & 03 & $<1$ \\
\hline Espírito Santo & 02 & $<1$ \\
\hline Goiás & 02 & $<1$ \\
\hline Mato Grosso do Sul & 01 & $<1$ \\
\hline Santa Catarina & 01 & $<1$ \\
\hline Total: & 3298 & 97 \\
\hline Sem informação: & 107 & 3 \\
\hline Total de carregadores & 3405 & 100 \\
\hline
\end{tabular}


Anexo 28:

Tabela: Origem dos Carregadores por Município no Piauí

\begin{tabular}{|c|c|c|c|}
\hline Município: & $\begin{array}{c}\text { Número de } \\
\text { Carregadores: }\end{array}$ & Município: & $\begin{array}{l}\text { Número de } \\
\text { Carregadores: }\end{array}$ \\
\hline Alto Longa & - jo & Oeiras & 24 \\
\hline Aroazes & 1 & Padre Marcos & 3 \\
\hline Avelino Lopes & 1 & Paes Landim & 3 \\
\hline Barras & 1 & Palmeira do Piauí & 7 \\
\hline Batalha & 2 & Paulistana & 7 \\
\hline Beneditino & 1 & Pedro II & 2 \\
\hline Bocaina & 64 & Picos & 584 \\
\hline Bom Jesus & 3 & Pimenteiras & 215 \\
\hline Caldeirão Grande & 2 & Pio IX & 103 \\
\hline Canto do Buriti & 27 & Rio Grande do Piauí & 35 \\
\hline Caracol & 1 & Santa Cruz do Piauí & 13 \\
\hline Castelo do Piauí & 2 & São Felix do Piauí & 2 \\
\hline Cristino Castro & 2 & São Francisco do Piaú́ & 2 \\
\hline Curralinhos & 1 & São Inácio do Piaú́ & 2 \\
\hline Dom Expedito Lopes & 1 & São João da Canabrava & 1 \\
\hline Elesbão Veloso & 3 & São João do Piauí & 22 \\
\hline Flores do Piauí & 13 & São José do Peixe & 6 \\
\hline Floriano & 22 & São José do Piauí & 552 \\
\hline Francisco Santos & 1 & Santa Cruz do Piauí & 16 \\
\hline Fronteiras & 52 & Santana do Paiuí & 2 \\
\hline Guadalupe & 2 & Santo Antonio de Lisboa & 17 \\
\hline Inhuma & 167 & São Miguel de Tapuio & 1 \\
\hline Ipiranga do Piauí & 6 & São Pedro do Piaúi & 1 \\
\hline Isaias Coelho & 3 & Simões & 1 \\
\hline Itaueira & 71 & Simplicio Mendes & 5 \\
\hline Jaicos & 3 & Socorro do Piauí & 7 \\
\hline Jurumenha & 1 & Sussuapara & 3 \\
\hline Lagoa do Sítio & 1 & Teresina & 10 \\
\hline Manoel Emídio & 1 & Valença do Piauí & 125 \\
\hline \multirow[t]{4}{*}{ Novo Oriente } & 14 & & \\
\hline & & Piauienses: & 2241 \\
\hline & & Sem informação & 35 \\
\hline & & Total de Piauienses & 2276 \\
\hline
\end{tabular}

Org.: Sueli de Castro Gomes

Fonte: Cadastro CEAGESP(2006) 
Anexo 29:

Tabela: Origem dos Carrregadores por Município no Ceará

\begin{tabular}{|c|c|c|c|}
\hline Município: & $\begin{array}{c}\text { Número de } \\
\text { Carregadores: }\end{array}$ & Município: & $\begin{array}{c}\text { Número de } \\
\text { Carregadores: }\end{array}$ \\
\hline Acopiara & $x^{2}$ & Jaguaruana & 14 \\
\hline Aguas Belas & 1 & Jardim & 2 \\
\hline Aiuba & 7 & Jordão & 2 \\
\hline Aracati & 4 & Juazeiro do Norte & 1 \\
\hline Araçoiaba & 1 & Jucás & 24 \\
\hline Araripe & 16 & Lagoa Nova & 1 \\
\hline Areias & 1 & Maranguape & 1 \\
\hline Assaré & 3 & Mombaça & 1 \\
\hline Aurora & 1 & Morada Nova & 4 \\
\hline Baixio & 1 & Nova russas & 1 \\
\hline Barão de Aquizaz & 1 & Novo Oriente & 1 \\
\hline Beberipe & 28 & Orós & 3 \\
\hline Boa Vista & 1 & Parambú & 5 \\
\hline Bocaine & 1 & Pedra Branca & 1 \\
\hline Bom Jesus Jardim & 1 & Pedrinhas & 1 \\
\hline Brejo Santo & 1 & Penaforte & 1 \\
\hline Campos Sales & 266 & Pereira & 4 \\
\hline Canafistula & 1 & Poço de Pedra & 1 \\
\hline Canindé & 1 & Pombal & 1 \\
\hline Caririaçu & 1 & Quixadá & 1 \\
\hline Carius & 14 & Quixeriu & 1 \\
\hline Cascavel & 1 & Redenção & 2 \\
\hline Cedro & 1 & Rendeira & 1 \\
\hline Chorozinho & 1 & Russas & 2 \\
\hline Crato & 4 & Saboeiro & 2 \\
\hline Fortaleza & 1 & Santana do Cariri & 1 \\
\hline Fortim & 1 & São Domingos & 1 \\
\hline G. do Norte & 1 & Senador Pompeu & 1 \\
\hline General Sampaio & 1 & Serra de Areia & 1 \\
\hline Granjeiro & 1 & Sobral & 3 \\
\hline Guixariu & 4 & Solonópolis & 1 \\
\hline Icó & 5 & Tarrafes & 1 \\
\hline Iguatu & 9 & Taua & 3 \\
\hline Independência & 3 & Umburama & 1 \\
\hline Inharé & 1 & Uruburetama & 3 \\
\hline Itagua & 7 & Varzea Alegre & 1 \\
\hline Itaiçaba & 1 & Viçoça do Ceara & 1 \\
\hline \multirow[t]{2}{*}{ Itapioca } & 1 & Estado do Ceará & 7 \\
\hline & & Total: & 498 \\
\hline
\end{tabular}

Org.: Sueli de Castro Gomes Fonte: Cadastro da CEAGESP (2006) 
Anexo 30:

Tabela : Município de Residência dos Carregadores da CEAGESP

\begin{tabular}{|c|c|}
\hline Município & Número de Carregadores: \\
\hline Arujá & 1 \\
\hline Barueri & 241 \\
\hline Biritiba-Mirim & 0 \\
\hline Caieiras & 2 \\
\hline Cajamar & 0 \\
\hline Carapicuíba & 422 \\
\hline Cotia & 4 \\
\hline Diadema & 1 \\
\hline Embu & 8 \\
\hline Embu-Guaçu & 1 \\
\hline Ferraz de Vasconcelos & 11 \\
\hline Francisco Morato & 26 \\
\hline Franco da Rocha & 9 \\
\hline Guararema & 0 \\
\hline Guarulhos & 26 \\
\hline Itapecerica da Serra & 4 \\
\hline Itapevi & 82 \\
\hline Itaquaquecetuba & 5 \\
\hline Jandira & 32 \\
\hline Juquitiba & 0 \\
\hline Mairiporã & 0 \\
\hline Mauá & 49 \\
\hline Moji das Cruzes & 3 \\
\hline Osasco & 1952 \\
\hline Pirapora do Bom Jesus & 0 \\
\hline Poá & 1 \\
\hline Ribeirão Pires & 3 \\
\hline Rio Grande da Serra & 1 \\
\hline Salesópolis & 1 \\
\hline Santa Isabel & 0 \\
\hline Santana de Parnaíba & 28 \\
\hline Santo André & 7 \\
\hline São Bernardo do Campo & 2 \\
\hline São Caetano do Sul & 4 \\
\hline São Lourenço da Serra & 0 \\
\hline São Paulo & 460 \\
\hline Suzano & 1 \\
\hline Taboão da Serra & 6 \\
\hline Vargem Grande Paulista & 2 \\
\hline Outros Municípios do Estado de SP & 10 \\
\hline Total: & 3405 \\
\hline
\end{tabular}


Anexo 31:

Tabela:Distrito de Residência dos Carregadores no Município de Osasco (2006)

\begin{tabular}{|c|c|c|c|}
\hline Distrito & Total & Distrito & Total \\
\hline Aldalgisa & 3 & $\mathrm{Km} 18$ & 0 \\
\hline Aliança & 71 & Conjunto Metalúgurgicos & 0 \\
\hline Airosa & 259 & Munhoz Jr. & 366 \\
\hline Bandeira & 16 & Mutinga & 101 \\
\hline Baronesa & 84 & Novo Osasco & 16 \\
\hline Bela Vista & 5 & Padroeira & 15 \\
\hline Bonança & 62 & Paiva Ramos & 0 \\
\hline Bonfim & 0 & Pestana & 2 \\
\hline Bussocaba & 1 & Piratininga & 74 \\
\hline Castelo Branco & 0 & Platina & 1 \\
\hline Centro & 0 & Portal D'Oeste & 35 \\
\hline Cidade das Flores & 0 & Presidente Altino & 0 \\
\hline Cidade de Deus & 0 & Quitaúna & 4 \\
\hline Cipava & 1 & Raposo Tavares & 0 \\
\hline City Bussocaba & 1 & Remédios & 20 \\
\hline Conceição & 233 & Rochdale & 322 \\
\hline Continental & 0 & Santa Fé & 0 \\
\hline Helena Maria & 2 & Santa Maria & 13 \\
\hline IAPI & 0 & Santo Antonio & 7 \\
\hline Indl. Altino & 0 & São Pedro & 13 \\
\hline Indl. Anhanguera & 6 & Setor Militar & 0 \\
\hline Indl. Autonomistas & 1 & Três Montanhas & 1 \\
\hline Indl. Centro & 0 & Umuarama & 1 \\
\hline Ind.Mazzei & 0 & Veloso & 27 \\
\hline Indl.Remédios & 0 & Vila Campesina & 1 \\
\hline Jaguaribe & 17 & Vila Menk & 17 \\
\hline Jardim D'Abril & 1 & Vila Militar & 1 \\
\hline Jardim das Flores & 3 & Vila Osasco & 10 \\
\hline Jardim Elvira & 41 & V. Yara & 0 \\
\hline \multirow[t]{3}{*}{ Jardim Roberto } & 4 & V. Yolanda & 1 \\
\hline & & Total & 1859 \\
\hline & & Não identificados & 38 \\
\hline
\end{tabular}

Org. Sueli de Castro Gomes e Rinaldo P. Gomes Fonte: Dados Cadastrais da CEAGESP (2006) 